Szegedi Tudományegyetem

Természettudományi és Informatikai Kar

Biológia Doktori Iskola

\title{
CRISPR/Cas rendszerek és kis RNS-eik expressziójára alkalmazott promóterek vizsgálata
}

\author{
Doktori (Ph.D.) értekezés
}

\section{Weinhardt Nóra}

Témavezető: Welker Ervin PhD, DSc

Biokémiai Intézet

Szegedi Biológiai Kutatóközpont

Magyar Tudományos Akadémia

Enzimológiai Intézet

Természettudományi Kutatóközpont

Magyar Tudományos Akadémia

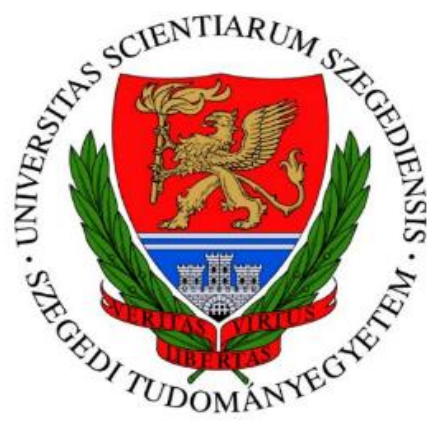

2020

Szeged 


\section{TARTALOMJEGYZÉK}

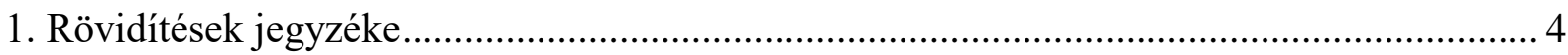

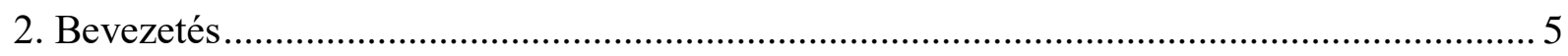

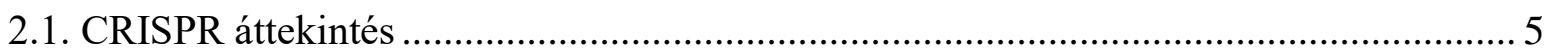

2.2. A CRISPR/Cas rendszerek off-target hatása és az ennek csökkentésére irányuló

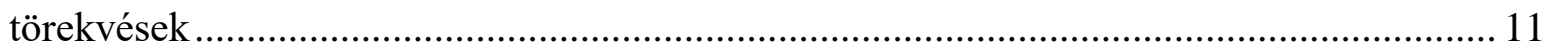

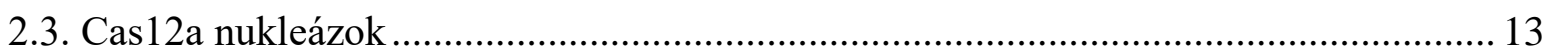

2.4. A CRISPR/Cas9 müködését befolyásolja a gRNS-ek mennyisége és hossza ............... 14

2.5. A CRISPR gRNS-ek expressziójára alkalmazott promóterek ...................................... 15

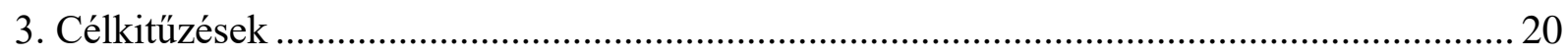

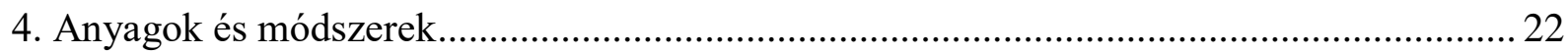

4.1. Plazmidok létrehozása a Cas12a nukleázok és a megnövelt specificitású SpCas9

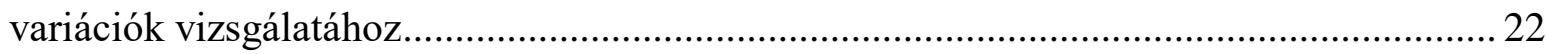

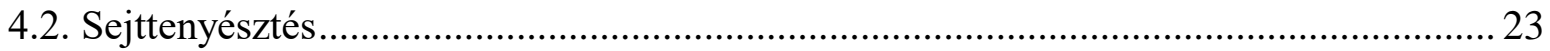

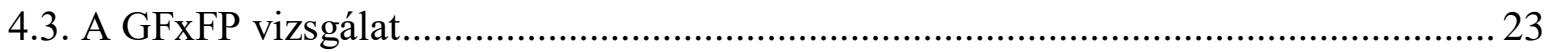

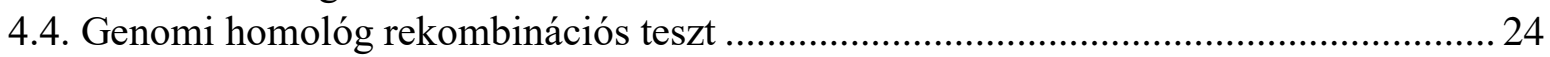

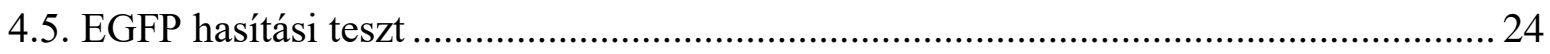

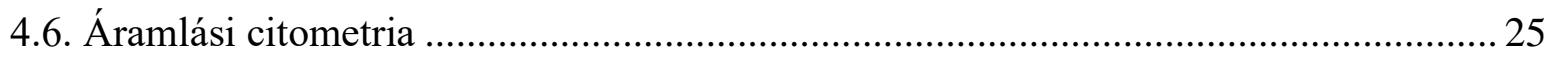

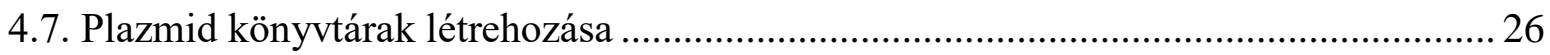

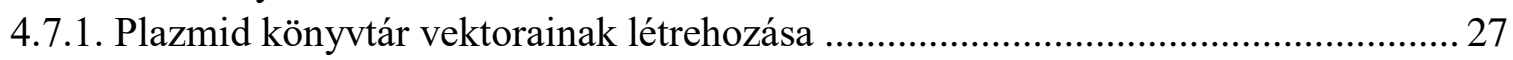

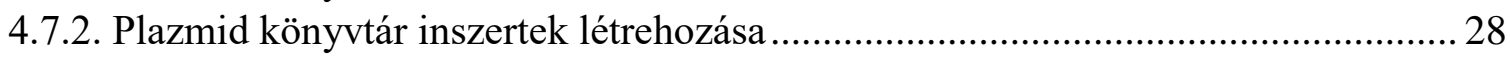

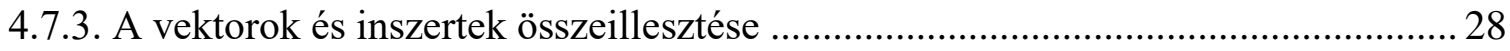

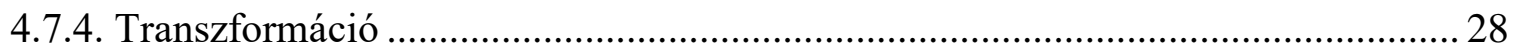

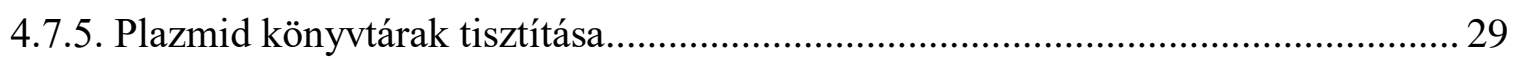

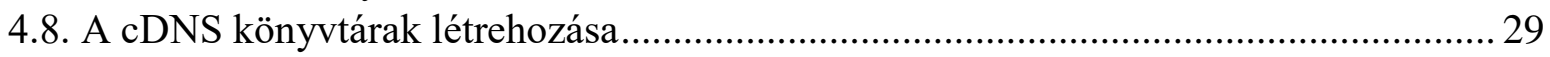

4.8.1. Emlős sejtek RNS könyvtárainak létrehozása .......................................................29

4.8.2. Bakteriális promóteres RNS könyvtárak létrehozása..........................................29

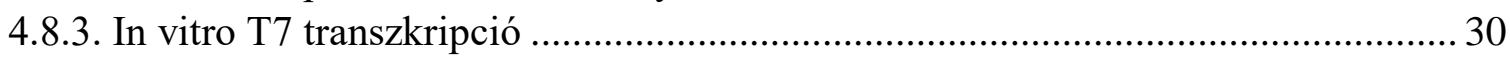

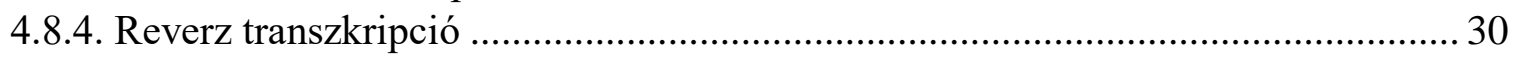

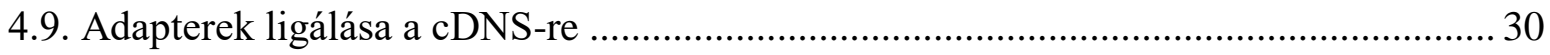

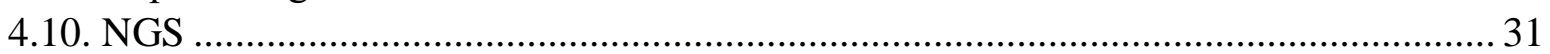

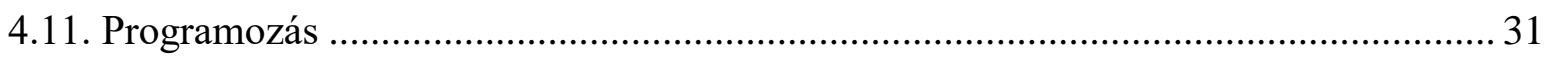

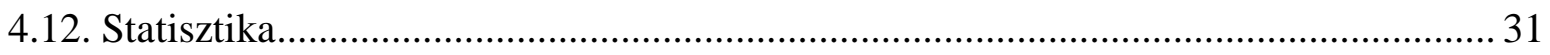

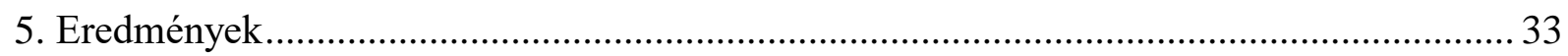

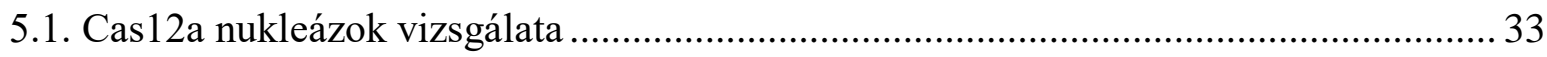

5.1.1. A GFxFP esszé módosítása............................................................................... 33

5.1.2. Az As- és LbCas12a hatékonyan indukálja a GFP kazetta javítását a GFxFP

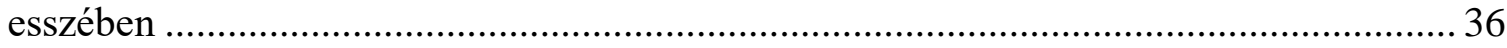

5.1.3. Az As- és LbCas12a nukleázok által végzett genomi DNS-hasítás hatékony HR javítást képes indukálni. 
5.2. Megnövelt specificitású SpCas9 nukleázok vizsgálata

5.2.1. 5' végükön nem G-t, vagy a 20. pozícióban nem komplementer G-t tartalmazó

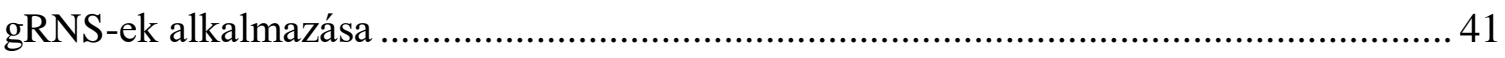

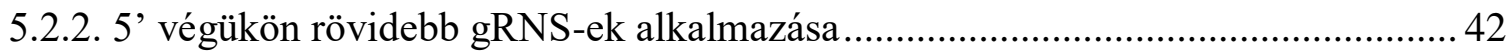

5.3. A CRISPR gRNS-ek expressziójára gyakran alkalmazott promóterek ........................... 43

5.3.1. A randomizált bázisokkal módosított gRNS ..................................................... 43

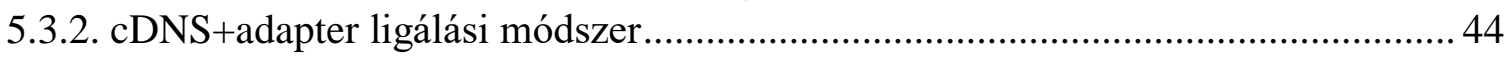

5.3.3. Emlős promóterek összehasonlítása................................................................. 45

5.3.4. A promótertől downstream elhelyezkedő +1 -től +4 -ig terjedő pozíciók vizsgálata az RNS expresszióra és a transzkripció iniciációs pozícióra .......................................... 46

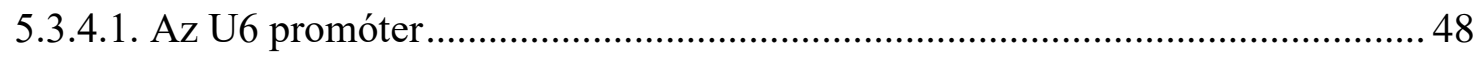

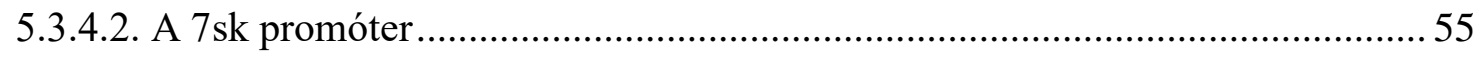

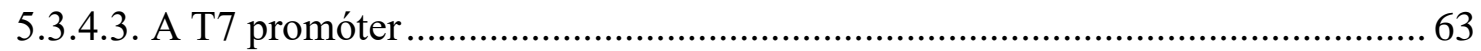

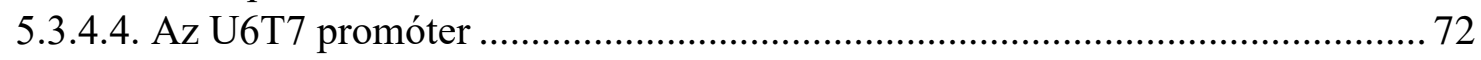

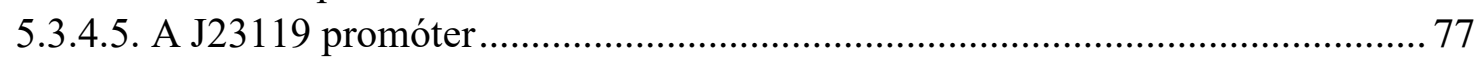

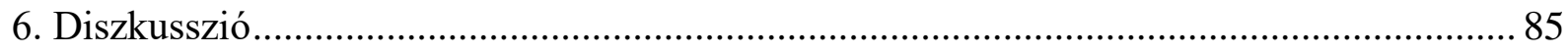

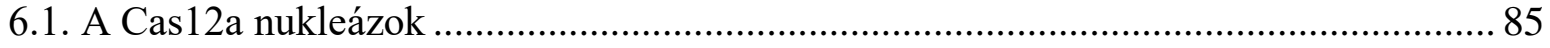

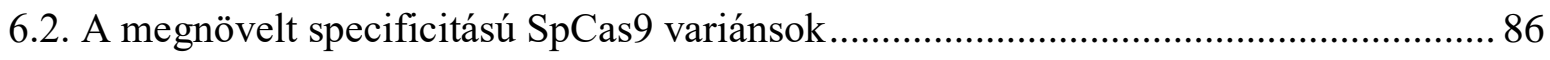

6.3. A CRISPR gRNS-ek expressziójára gyakran alkalmazott promóterek ......................... 87

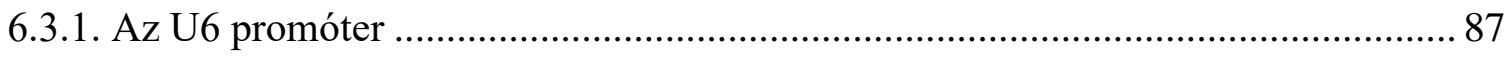

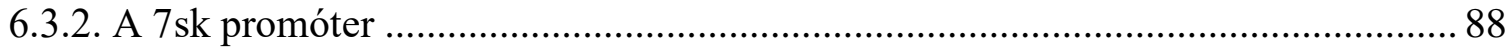

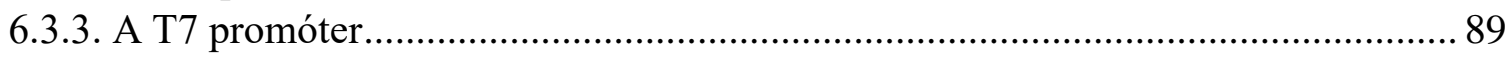

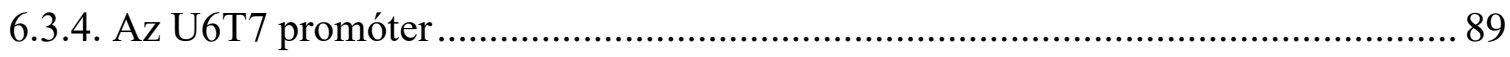

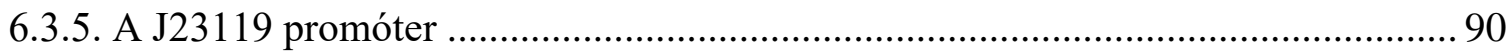

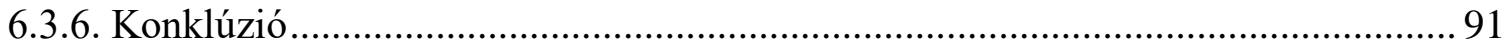

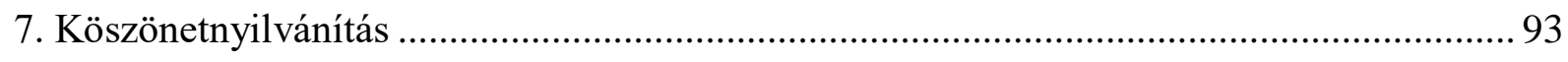

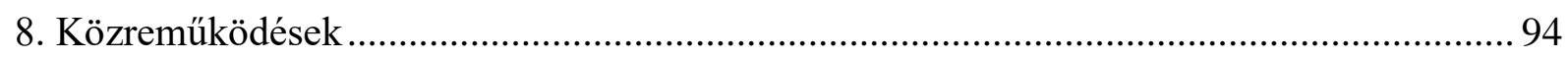

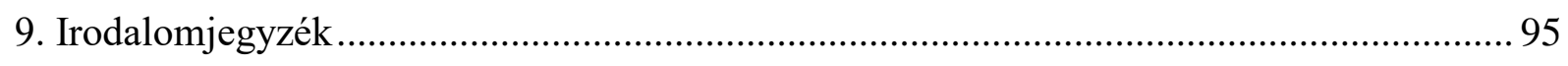

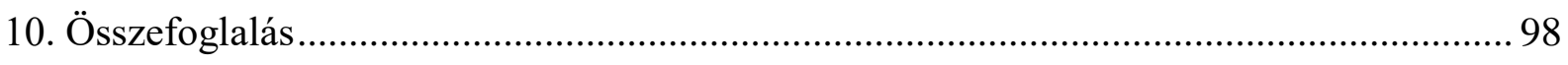

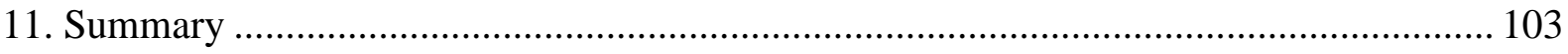

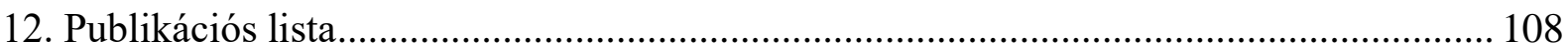

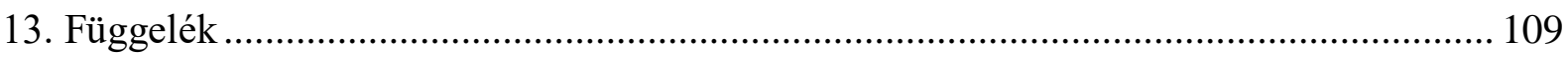




\section{Rövidítések jegyzéke}

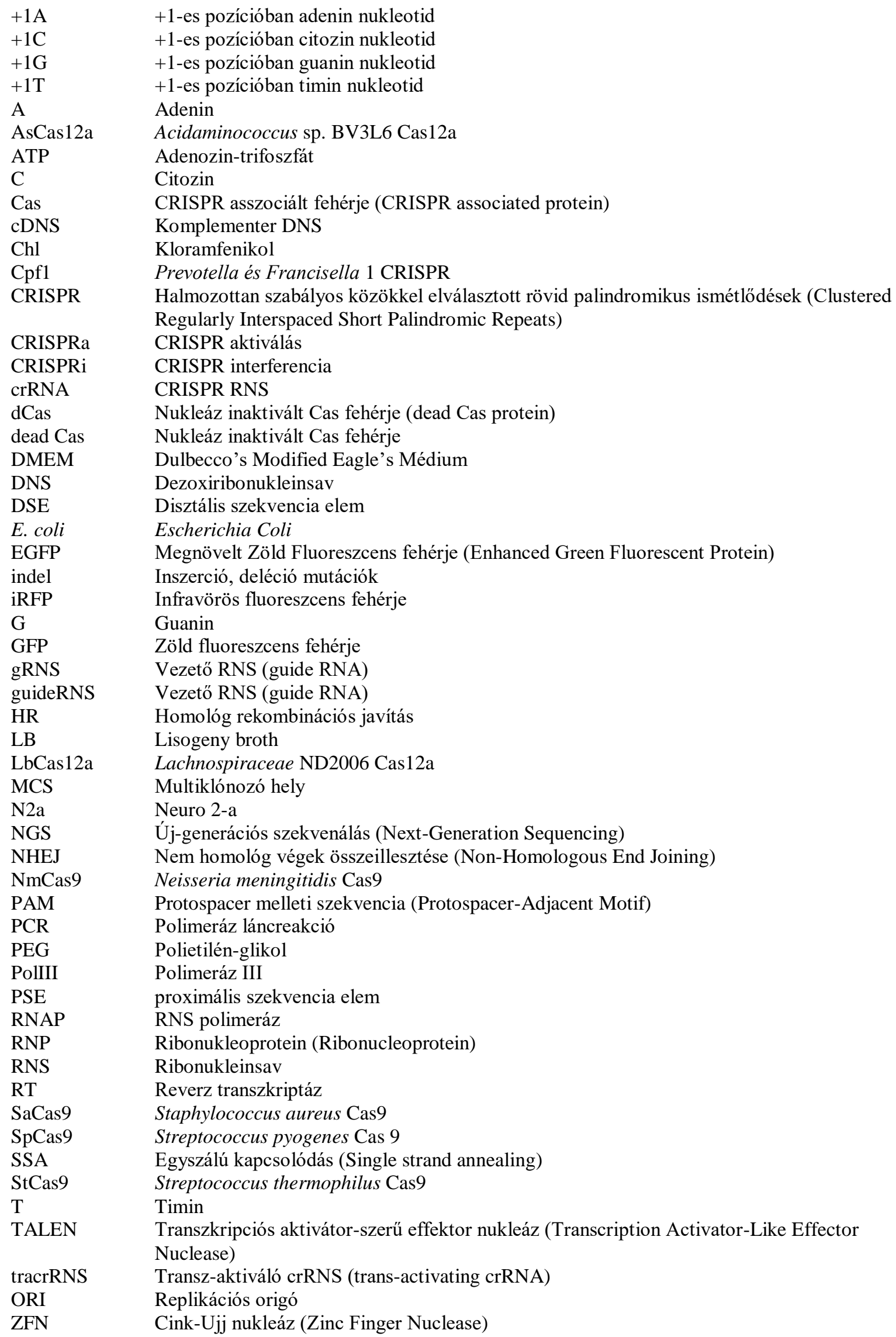




\section{Bevezetés}

\subsection{CRISPR áttekintés}

Számtalan biológiai mechanizmus felfedezéséhez és tanulmányozásához elengedhetetlen a genetikai információ szerkesztésének képessége. Az alkalmazott tudományok, a biotechnológia és az orvostudomány területén is hatalmas szükség van olyan technikákra, amelyekkel a DNS specifikus szakaszait lehet irányíthatóan módosítani. A mindössze néhány éve elterjedt CRISPR rendszer forradalmi változásokat okozott annak köszönhetően, hogy egyszerüen, egy rövid RNS szekvencia módosításával képes nagy hatékonysággal a kívánt DNS szakaszt módosítani.

A CRISPR rendszer elterjedését megelőzően restrikciós enzimeken alapuló génszerkesztő technológiákat is alkalmaztak a genom módosítására, ilyenek a cink-ujj nukleázok (ZFN) és az aktivátorszerü effektor nukleázok (TALEN). Ezen technológiák hátránya, hogy minden egyes kísérlethez fehérjeszinten kell megváltoztatni a molekulákat, mivel ezeknél a módszereknél a DNS szekvenciák felismerése nem RNS-DNS, hanem fehérje-DNS kötésen alapul ${ }^{1,2}$.

A természetben a CRISPR/Cas rendszer a külső behatolókkal szembeni védekezés része prokariótákban, melynek során felismerik és elhasítják a támadó organizmusok nukleinsavait. A védekezés az adaptáció, az expresszió és érés, valamint az interferencia szakaszokból áll (1. ábra). Az adaptáció során a Cas9 fehérjék az idegen DNS-ből rövid szakaszokat (a protospacereknek nevezett szekvenciákat) a prokarióta genomba építik. Ezeket a beépített szekvenciákat spacereknek hívják (1. ábra, a). A spacereket a CRISPR lókusz ismétlődő szekvenciái határolják, és egy újabb támadás esetén felhasználhatók a védekezéshez. Az expressziós és érési szakaszban átíródnak a Cas9 fehérjéket, a pre-crRNS-eket (CRISPR RNS), és a tracrRNS-t (transzaktiváló crRNS) kódoló gének. A pre-crRNS-ekből létrejönnek az egyegy spacer szekvenciát tartalmazó, egyedi crRNS-ek (1. ábra, b). Az interferencia fázisban létrejön a Cas9-crRNS és tracRNS fehérje-RNS komplex. A tracrRNS részben komplementer a crRNS-el és együttesen egy RNS duplexet hoznak létre, amelyet felismer és köt a Cas9. A nukleáz a spacer szekvencia segítségével Watson-Crick bázispárosodás alapján azonosítja az idegen DNS molekulákat, amelyeket mindkét szálon elhasít (1. ábra, c). A cél-DNS felismeréséhez szükség van még egy konzervált, néhány bázispáros szakasz jelenlétére a célszekvencia mellett, ez a protospacer melletti motívum (PAM) szekvencia, amelynek segítségével a Cas9-cRNS-tracrRNS komplex megkülönbözteti az idegen DNS-t a saját DNSétől $1^{2-4}$. 


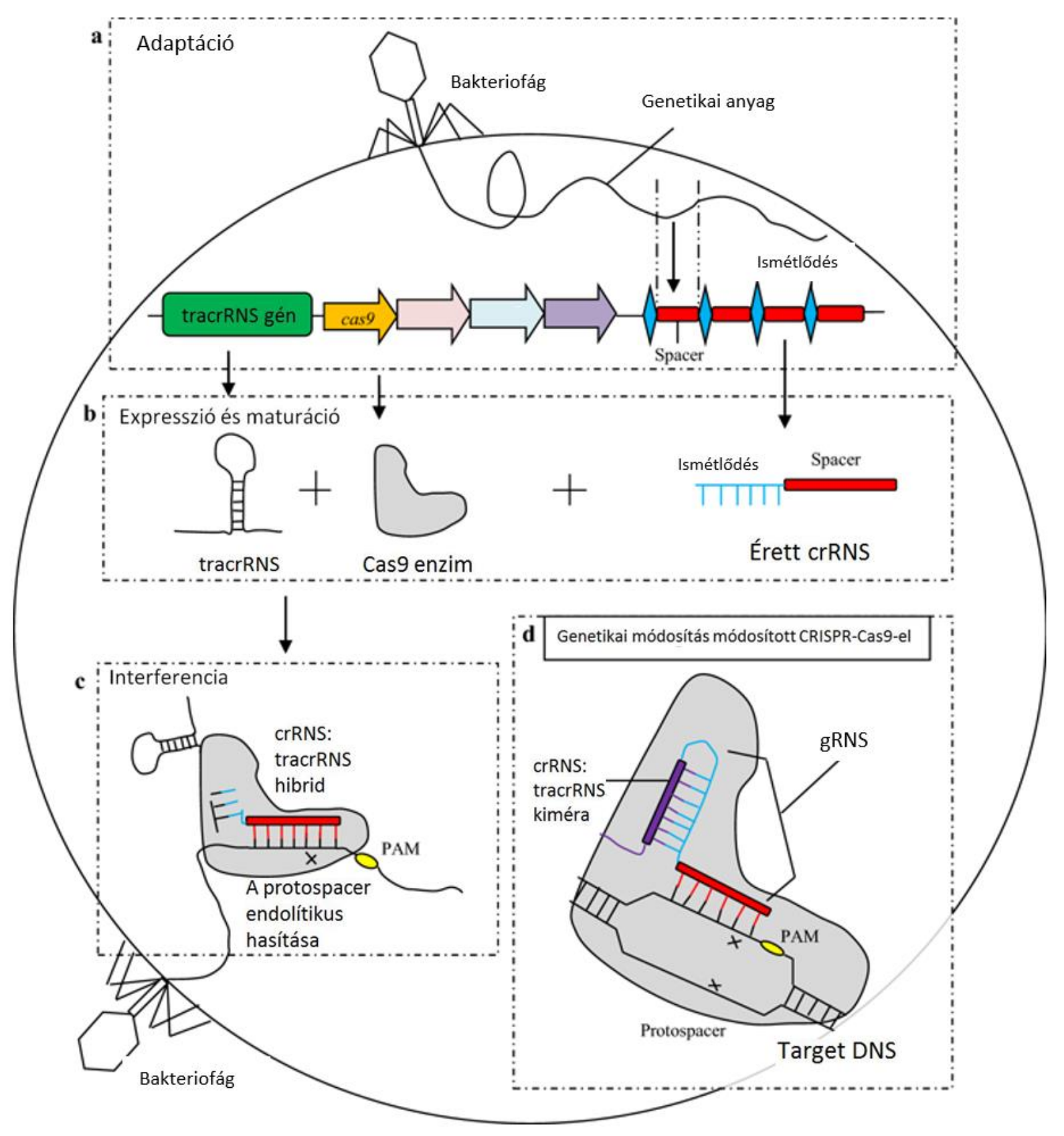

1. Ábra. A prokariótákban létező természetes CRISPR/Cas9 rendszer mechanizmusa és a genomszerkesztésre használt módosított CRISPR/Cas9 technológia

a - c, A természetben létező CRISPR/Cas9 rendszer mechanizmusának három fő fázisa van.

a, Adaptáció: a baktériumok az őket támadó vírusokból a ,protospacernek” nevezett specifikus genomi szekvenciákat szereznek, és beépítik azokat a CRISPR lókuszba. Ezek a spacerek. b, Expresszió és érés: A tracrRNS, a Cas9 enzim és a crRNS exresszálódnak. A pre-crRNS-ekböl egyedi spacereket tartalmazó crRNS-ek keletkeznek. c, Interferencia: megtörténik a crRNS és a tracrRNS bázispárosodása, amely crRNS: tracrRNS hibriddé alakul, majd ezek később a Cas9 fehérjékkel komplexet alkotnak. A hibrid RNS alapján a Cas9 fehérje megtalálja a spacerrel komplementer protospacer célszekvenciát, melyek között bázisbárosodás történik, majd a Cas9 nukleáz hasítja a target DNS mindkét szálát. d, A genomszerkesztés során a kiméra gRNS-t a tracrRNS és a crRNS hibridizációjával állítják elõ. A gRNS spacere alapján a Cas9 nukleáz felismeri azokat a célszekvenciákat, amelyek a protospacerrel szomszédos motívum (PAM) szekvenciától upstream helyezkednek el és a DNS mindkét szálát hasítja² ${ }^{2}$ Ábra forrása: Barman és mtsai, 2019 alapján. 
A Streptococcus pyogenes baktériumból származó Cas9 endonukleáz (SpCas9) jelenleg a génmódosításra legelterjedtebben alkalmazott CRISPR/Cas rendszer. A specificitást a crRNS (1. ábra, c), vagy ennek mesterségesen továbbfejlesztett verziójaként a crRNS és a tracrRNS fúziójából létrehozott guideRNS (gRNS) 5' végén elhelyezkedő 20 bázispáros szekvencia, a spacer biztosítja. A spacer segítségével kerül felismerésre a célszekvencia (target) komplementer DNS-RNS hibridizáció alapján (1. ábra d, és 2. ábra). A target szekvencia duplaszálú DNS-e kihurkolódik és a komplementer szekvenciák között RNS-DNS heteroduplex keletkezik a gRNS és a cél DNS között. A Cas9 nukleáz hasítja a targetet és a targettel komplementer DNS szálat is, így kettős szálú töréseket generál².

A mai molekuláris biológiai technikákkal már könnyedén változtatható a spacer szekvenciája, ennek köszönhető a rendszer robbanásszerü elterjedése ${ }^{2,5}$. A Cas9 fehérje segítségével szinte bármilyen genomi szakasz szabadon módosítható, ezért jelentős biotechnológiai, orvosi és tudományos felhasználása van.

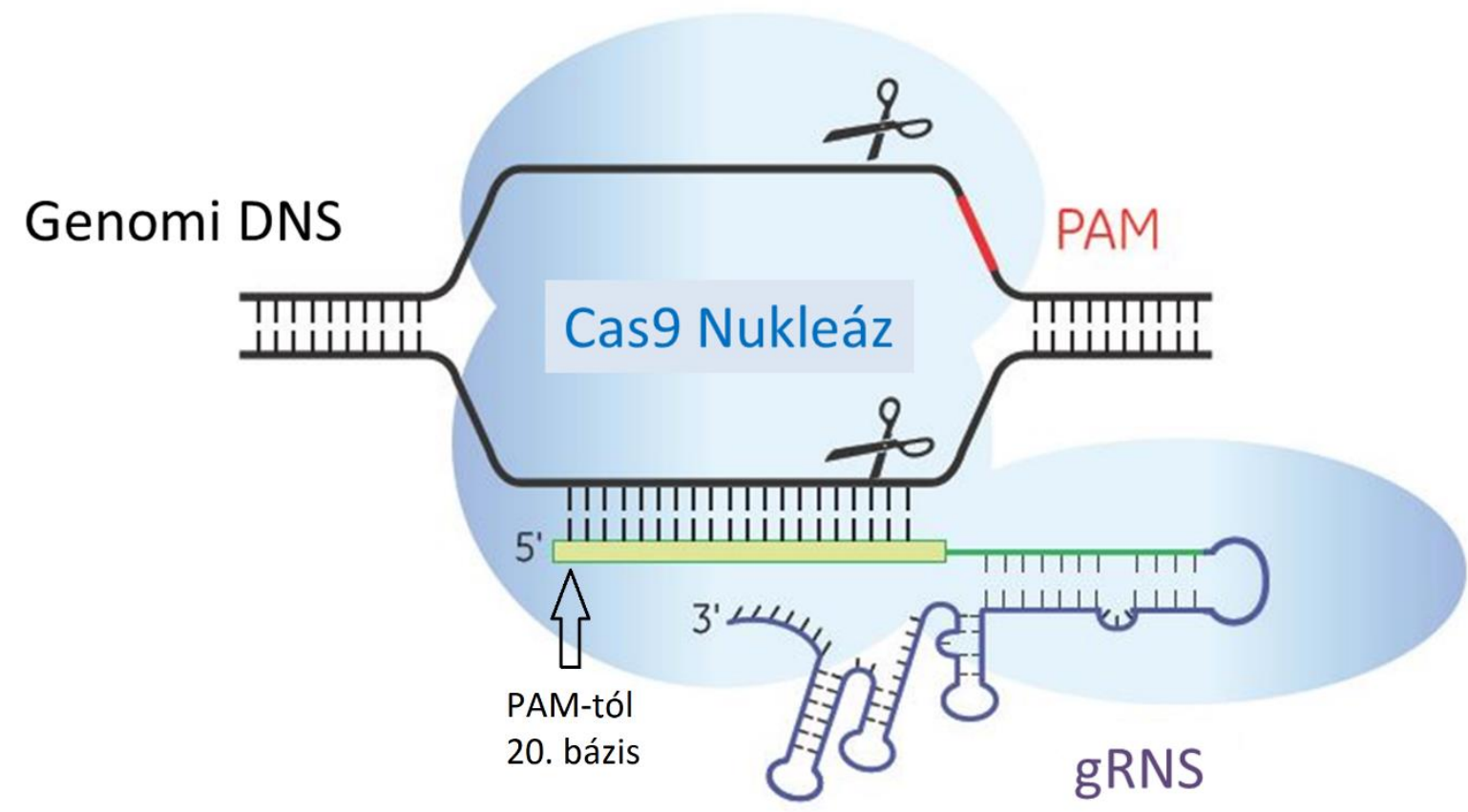

\section{2. Ábra. Cas9 nukleáz a gRNS-el és a genomi target DNS-el}

Az ábrán a Cas9 nukleáz, a gRNS és a genomi target DNS együttesen látható sematikusan ábrázolva. Kék színnel a fehérje, ollókkal a DNS duplaszálú hasítása, feketével a target és környezetének szekvenciája, pirossal a PAM szekvencia van jelölve. A gRNS spacer szekvenciája, amely a targettel komplementer, sárgával van jelölve és a guideRNS 3' részével folytatódik, amelynek erős másodlagos szerkezete van. A spacerben fekete nyíllal van jelölve a gRNS 5' első bázisa, amelyet 20. pozíciónak szoktak nevezni, mert a PAM-tól 20 bázisra található a targetben az ennek megfelelő nukleotid. Ábra forrása: https://horizondiscovery.com/en/products/geneediting/gene-editing-reagents/crispr-guide-rna oldal alapján. 
Az SpCas9 az NGG szekvenciájú, 3 bázispáros PAM motívumot ismeri fel. A DNS duplaszáltörése az SpCas9 esetében a targetben a 17. és a 18. bázispárok között történik a spacer 5' végétől számolva és tompa végek keletkeznek (3. ábra). A Bacteriák és Archeák különböző fajai között a CRISPR/Cas rendszer számos variációja alakult ki, amelyek alapján a CRISPR rendszerek többféle osztályba és csoportba sorolhatók. A különböző, eddig felfedezett CRISPR/Cas fehérjék eltérő PAM motívumokat ismerhetnek fel, és eltérő lehet a DNS hasítás módja is (3. ábra) $)^{6}$.

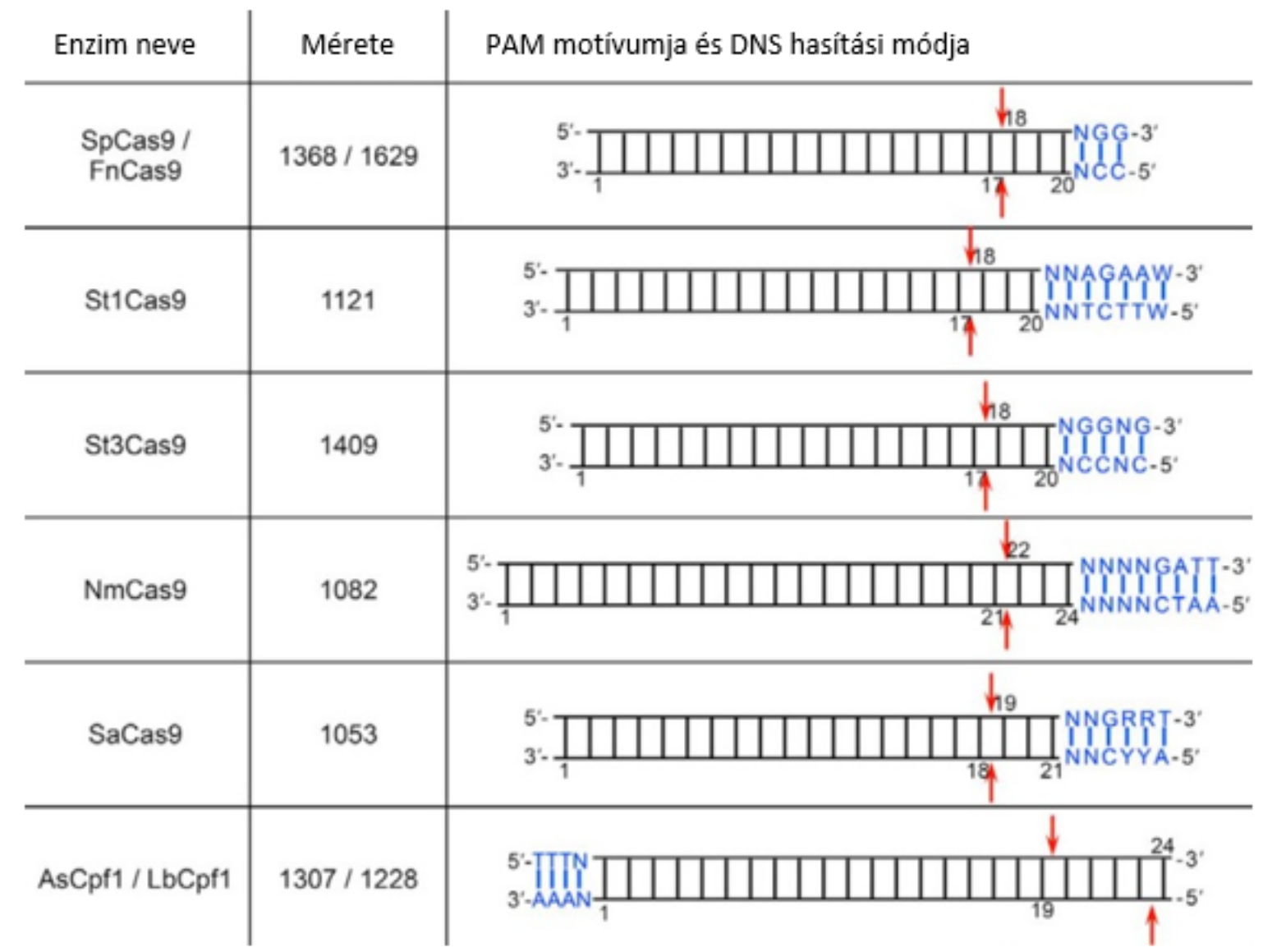

\section{3. Ábra. Néhány eddig felfedezett CRISPR/Cas rendszer PAM szekvenciája és DNS hasítási módja}

Az ábrán néhány eddig felfedezett Cas fehérje és az általuk felismert PAM motívumok, valamint a DNS hasítási módjuk látható. Kék színnel a PAM motívumok szekvenciái, piros nyilakkal a PAM szekvenciától a megjelölt bázispárnyi távolságra létrejövő hasítás helye látható. ${ }^{6}$. Ábra forrása: Komor és mtsai, 2016 alapján.

A különféle Cas nukleázok által létrehozott DNS duplaszáltörés két fö mechanizmussal javítódik a sejtekben, és mindkét javítási mechanizmus által módosulhat a DNS szekvencia (4. ábra, a). Az NHEJ mechanizmus által indel mutációk hozhatók létre a kívánt szakaszon, a homológ rekombinációs hibajavítás (HR) során pedig templát DNS jelenlétében a szekvencia pontos módosítása érhető $\mathrm{el}^{7}$. Az SSA hibajavítás a homológ rekombinációs javítás egyik altípusa (nincs ábrázolva), amely két ismétlődő szekvencia között történik. 
Az SSA hibajavítás során az 5-3' irányban visszaemésztett szálaknál a két ismétlődő szekvencia szolgál templátul, amelynek eredményeképp az eredetileg kétszer előforduló szekvencia helyett csak 1 kópia marad meg és a közbenső szekvenciák kiesnek.

A CRISPR rendszerrel többféle módon valósítható meg a genom irányított szerkesztése, melynek néhány típusa a 4. ábra a, b és c részén látható. Génmódosítás hozható létre „klasszikus” módon, a duplaszálú DNS hasítása által kiváltott DNS javítási eljárással (3. ábra a). A DNS kötésre képes, de hasításra nem képes inaktív dCas (nukleáz inaktivált, dead Cas) fuzionálható deaminázokkal, hogy egy aminocsoportot a citozinban, vagy adeninben hidrolizáljanak, mellyel specifikus bázis módosítás, C->T, illetve A-> G konverzió érhető el. Az RNS-ek bázis szerkesztéséhez az RNS-re ható adenozin-dezaminázokat fuzionálják a dCas13 enzimhez ${ }^{7-9}$ (4. ábra b). Egy másik módszer a transzpozábilis elemek helyspecifikus integrációját képes indukálni a transzpozáz komplexek inaktív Cas12-vel történő irányításával ${ }^{10}$ (4. ábra c). A prime editing nevű módszer szintén alkalmas génszerkesztésre (nincs ábrázolva). Ennek során egy, csak a DNS egyik szálát hasító mutáns Cas9-et (nikáz) fuzionálnak reverz transzkriptázzal. A gRNS 3' végét pedig a target módosítására alkalmas donor szekvenciával hosszabbítják meg, amelyet a reverz transzkriptáz átír, a keletkezett ssDNS pedig beépül az egyik szálon hasított target szekvenciába ${ }^{11}$.

A CRISPR/Cas rendszerrel génszabályozás is végbe vihető. Többféle transzkripciós, vagy epigenetikus szabályozót lehet közvetlenül fuzionálni, vagy RNS-protein kölcsönhatásokkal közvetve kapcsolni a dCas-okhoz. A gének expresszióját lehet aktiválni, (CRISPRa), vagy gátolni (CRISPRi), a kapcsolt szabályozó fehérjék funkcionális jellegétől függően. Helyspecifikus génszabályozás hozható létre még epigenetikai szabályozók fúziójával szintén a dCas nukleázok segítségével (4. ábra d). 


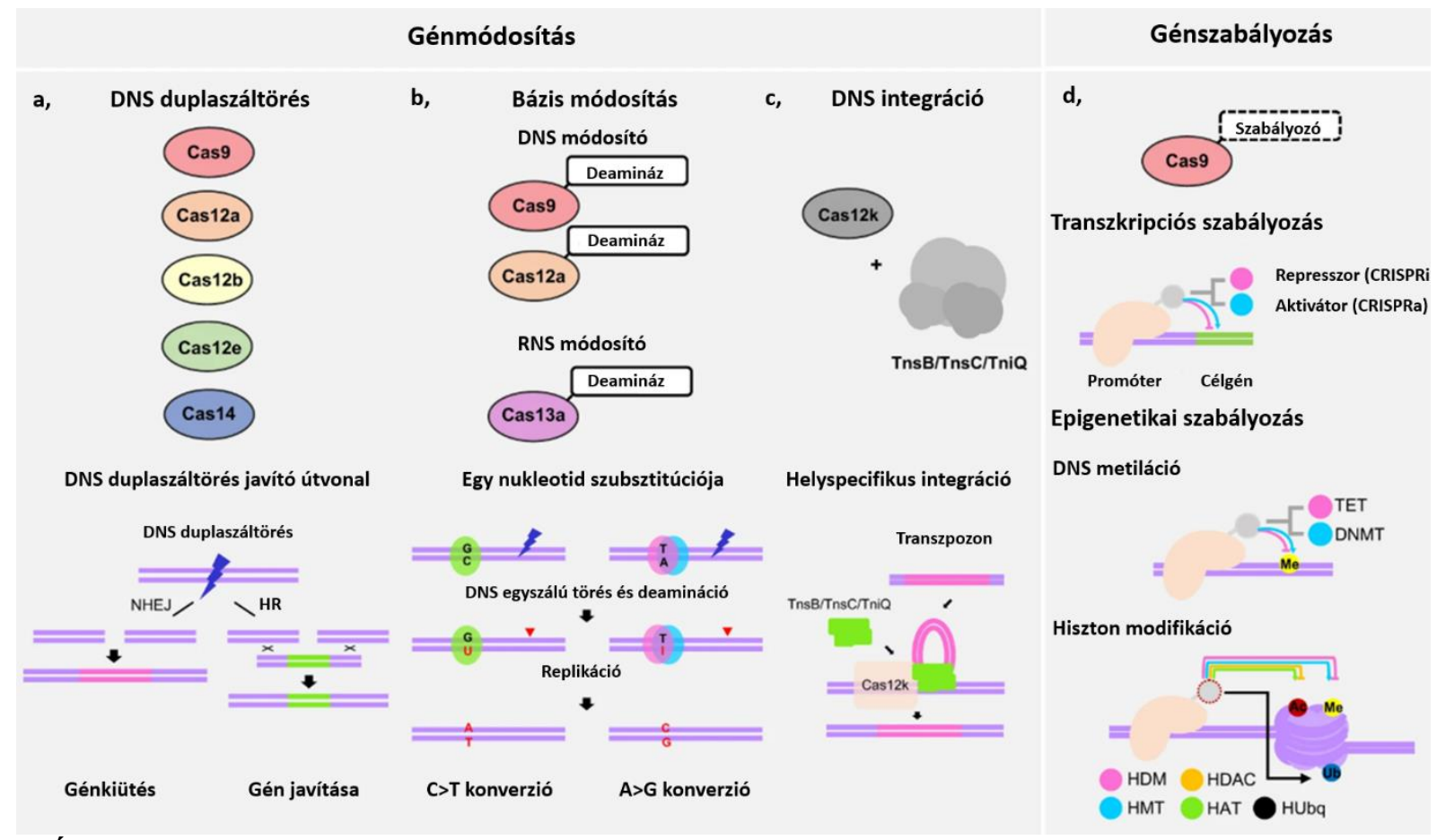

\section{4. Ábra. Génmódosítás és génszabályozás CRISPR-el}

Az ábrán a CRISPR/Cas rendszerek által elérhető főbb génmódositási és génszabályozási típusok láthatók. a, $\mathrm{A}$ különféle nukleázok által létrehozott DNS duplaszáltörés két fö mechanizmussal javítódik a sejtekben, NHEJ, vagy homológ rekombinációs hibajavítással (HR). b, Az inaktív Cas nukleázok fuzionálhatók deaminázokkal, mellyel specifikus bázis módosítás érhető el. Az RNS-ek bázis szerkesztéséhez az RNS-re ható adenozindezaminázokat fuzionálják a dCas13 enzimhez. c, A transzpozábilis elemek helyspecifikus integrációját képesek indukálni a transzpozáz komplexek, inaktív Cas12 irányításával. d, A transzkripciós, vagy epigenetikus szabályozókat lehet közvetlenül fuzionálni, vagy RNS-protein kölcsönhatásokkal közvetve kapcsolni a dCasokhoz. A gének expresszióját lehet aktiválni, (CRISPRa), vagy gátolni (CRISPRi), a kapcsolt szabályozó fehérjék funkcionális jellegétől függően. Génszabályozás érhető el epigenetikai szabályozók fúziójával a dCas nukleázokon keresztül ${ }^{7}$. Ábra forrása: Moon és mtsai 2019 alapján.

Annak ellenére, hogy a CRISPR/Cas rendszereknek ma már számtalan biotechnológiai alkalmazása van, vannak limitációi is. Az egyik, hogy nem minden target szekvenciával képesek hatékony működésre. Ennek megoldására nyújthat segítséget a többféle ismert nukleáz alkalmazása, valamint olyan Cas9 verziók használata, ahol az SpCas9 nemcsak NGG, hanem NG PAM-al is képes müködni, amelyekkel megnövelhető a lehetséges targetek száma ${ }^{12,13}$. A CRISPR-es alkalmazásoknál nagy nehézséget okoz a hatékony bejuttatás is, ezeknek a fejlesztésével számos csoport foglalkozik ${ }^{14}$. A CRISPR másik hátránya az off-target hatás, amely részletesebben a következő fejezetben kerül kifejtésre. 


\subsection{A CRISPR/Cas rendszerek off-target hatása és az ennek csökkentésére irányuló törekvések}

A CRISPR/Cas rendszerek használata során felmerülő egyik legnagyobb probléma az off-target hatás. A gyakorlatban ez azt jelenti, hogy a CRISPR/Cas rendszerek által célozni kívánt DNS szekvencián kívül a Cas fehérjék más, a célszekvenciához hasonló genomi pozíciókat is hasítanak ${ }^{15}$. Ez nemkívánt mellékhatásokat eredményezhet a kísérlet, vagy a potenciális gyógyászati beavatkozás során.

Ma már a különböző Cas fehérjékre többféle adatbázis nyújthat segítséget olyan targetek kiválasztásához, amelyeknek viszonylag kevés számú off-targete van az adott organizmusban. Azonban az változatlanul rosszul prediktálható, hogy melyik off-target kerül hasításra. Ezért számos stratégiát közöltek a szakirodalomban a gRNS módosításától kezdve, a Cas9 fehérjék módosításán keresztül a fúziós fehérje rendszerek létrehozásáig ${ }^{15}$.

Az 5. ábra a részén szerepelnek ezek közül a megnövelt specificitású Cas9 variációk időrendi sorrendben az SpCas $9{ }^{2 \text { Pro }}$-ig bezárólag. Az egyik legizgalmasabb és egyben legelterjedtebb módszer ezen mutációkkal létrehozott megnövelt specificitású SpCas9 variánsok alkalmazása az off-target hatás csökkentése érdekében. Az eSpCas9 ${ }^{16}$, SpCas9-HF1 ${ }^{17}$, HypaCas9 ${ }^{18}$ és SpCas9 $9^{2 P r o} 19$ a fehérjeszerkezet ismeretében, különböző mutációk bevitelével készültek, az evoCas9 ${ }^{20}$, xCas9 ${ }^{12}$ és a Sniper-Cas $9{ }^{21}$ pedig irányított evolúcióval (5. ábra a).

Az off-target hatás csökkentésére irányuló másik módszer a gRNS-ek módosítása. Ezek többsége az RNS 5' végén fordul elö, beleértve a gRNS kettő vagy három bázissal való csonkítását $^{22}$, két guanin nukleotiddal való meghosszabbítását ${ }^{23}$ és az 5 ' vég DNS-el való helyettesítését ${ }^{15,24}$. A kémiailag módosított nukleotidok, például a 2'- O-metil-3' -foszfonoacetát (MP) és az áthidaló nukleinsavak (2', 4'-BNANC [N-Me]) a gRNS meghatározott szakaszain szintén nagymértékben csökkentik az off-target hatást ${ }^{15,25,26}$ (5. ábra b).

Az 5. ábrán felsorolt megoldásokon kívül elterjedt módszernek számít még a dCas9 fúziója különböző fehérjedoménekkel. Ilyen például az inaktivált dCas9-el fuzionált Fok1 nukleázok alkalmazása ${ }^{27}$. Mivel a dCas9 csak a DNS kötésére képes, semmilyen targetet nem képes hasítani, így az off-targeteket sem. A fúziós megoldások közül az egyik legújabb megközelítés a dCas9 és egy bázis módosító fehérje (mint a citidin vagy adenin deamináz) fúziója, amelynek segítségével DNS törése nélkül is lehet mutációkat bevinni a génekbe (4. ábra, b) ${ }^{28-30}$.

Egy másik módszer az off-target hatás csökkentésére a Cas nukleáz aktivitásának időbeli csökkentése, ami például indukálható nukleázokkal érhető el. A nukleáz aktivitási idejének csökkentésével a kívánt targetek még elhasítódnak, az off-targetek pedig már kevésbé ${ }^{31,32}$. 
Az off-target hatást sikeresen csökkenti még a nikázok használata. Ezek olyan mutáns nukleázok, amelyek csak a DNS egyik szálát képesek hasítani ${ }^{33}$.

A felsorolt módszereken kívül többen bemutatták, hogy a Cas12a nukleázok specifikusabbak, mint az SpCas9 $9^{34-36}$.

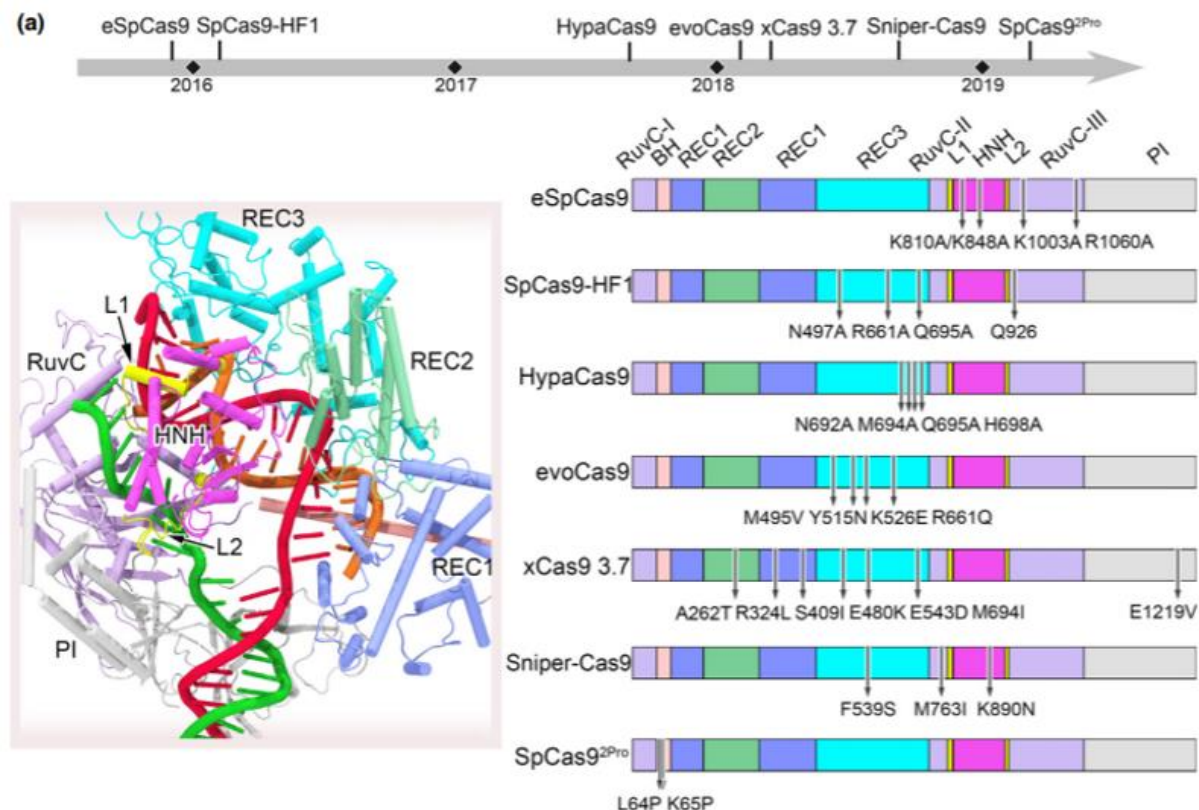

(b) Teljes hosszúságú gRNS
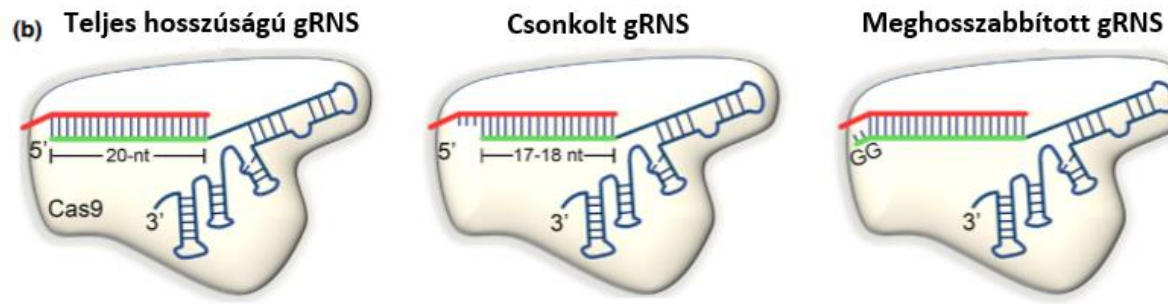

Részleges DNS szubsztítúció

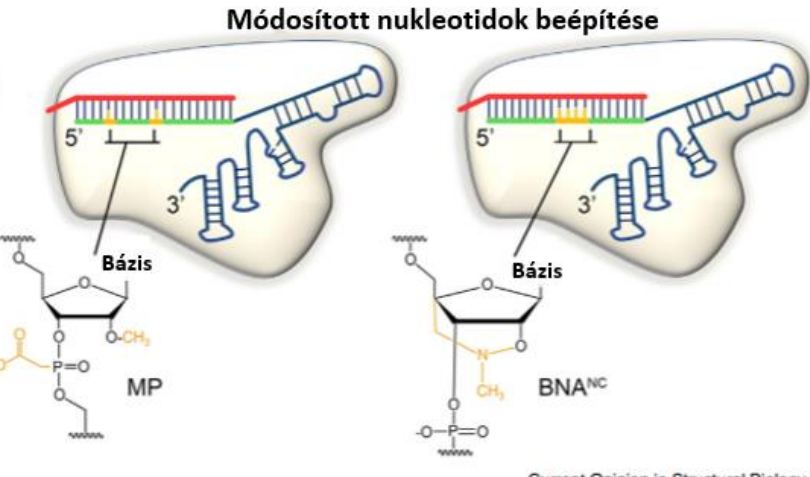

5. Ábra. A CRISPR/Cas off-target hatás csökkentésére irányuló törekvések a fehérje, vagy a gRNS módosításával

a, A felső panel a különféle megnövelt specificitású Cas9 változatokat ábrázolja a megjelenésük éve szerint időrendi sorrendben, az SpCas9 ${ }^{2 \mathrm{Pro}}$-ig bezárólag. Alatta bal oldalon látható a fehérjeszerkezet modellezve, a Cas9 doménekkel. Mellette jobb oldalon a különbözö megnövelt specificitású Cas9 változatok szekvenciájában létrehozott mutációk sematikus ábrázolása látható. b, A specificitás növelése érdekében alkalmazott gRNS módosítások vázlatos rajza. MP: 2'- O-metil-3' -foszfono-acetát. BNA ${ }^{\mathrm{NC}}: 2^{\prime}, 4^{\prime}-\mathrm{BNA}^{\mathrm{NC}}[\mathrm{N}-\mathrm{Me}]^{15}$. Ábra forrása: Zuo és mtsai, 2020 alapján. 


\subsection{Cas12a nukleázok}

A közelmúltban Zetsche és mtsai megvizsgálták a Cas12a (másnéven Cpf1) nukleázokat, hogy alkalmazhatók-e génszerkesztési feladatokra ${ }^{35,37}$. Ez a munka a Cas12a-k olyan, a 6. ábrán is látható tulajdonságait tárta fel, amelyek általánosnak tűnnek ugyan a Cas12a nukleázok között, de a Cas9-ekre nem jellemzőek. A Cas12a egyetlen crRNS-el müködik, ellentétben a Cas9-el, amely tracrRNS-t is igényel a target felismerő aktivitáshoz. A Cas12a-k által felismert PAMmotívum meglehetősen T-ben gazdag, ellentétben például az SpCas9-el, amely NGG szekvenciájú PAM-ot ismer fel. Míg a Cas9 nukleázok tompa DNS végeket hoznak létre a DNS kettős szál törésekor, a Cas12a 4 vagy 5 nukleotid hosszú 5' túlnyúlójú végeket eredményez ${ }^{35,37}$. Az úttörő tanulmányban Zetsche és mtsai $16 \mathrm{db}$ Cas12a nukleázt vizsgáltak meg in vitro, melyből kettőt találtak alkalmasnak hatékony genomszerkesztésre a HEK-293FT sejtekben. Az AsCas12a-t az Acidaminococcus sp. BV3L6, az LbCas12a-t a Lachnospiraceae ND2006 baktériumokból azonosították. Ezekben a kísérletekben kevés targeten és csak az NHEJ javítási útvonal kiaknázásával vizsgálták a Cas12a nukleázok aktivitását és eredményeik alapján az AsCas12a és LbCas12a által létrehozott indel gyakoriság magasabb volt, mint az SpCas9-é ${ }^{35,37}$.
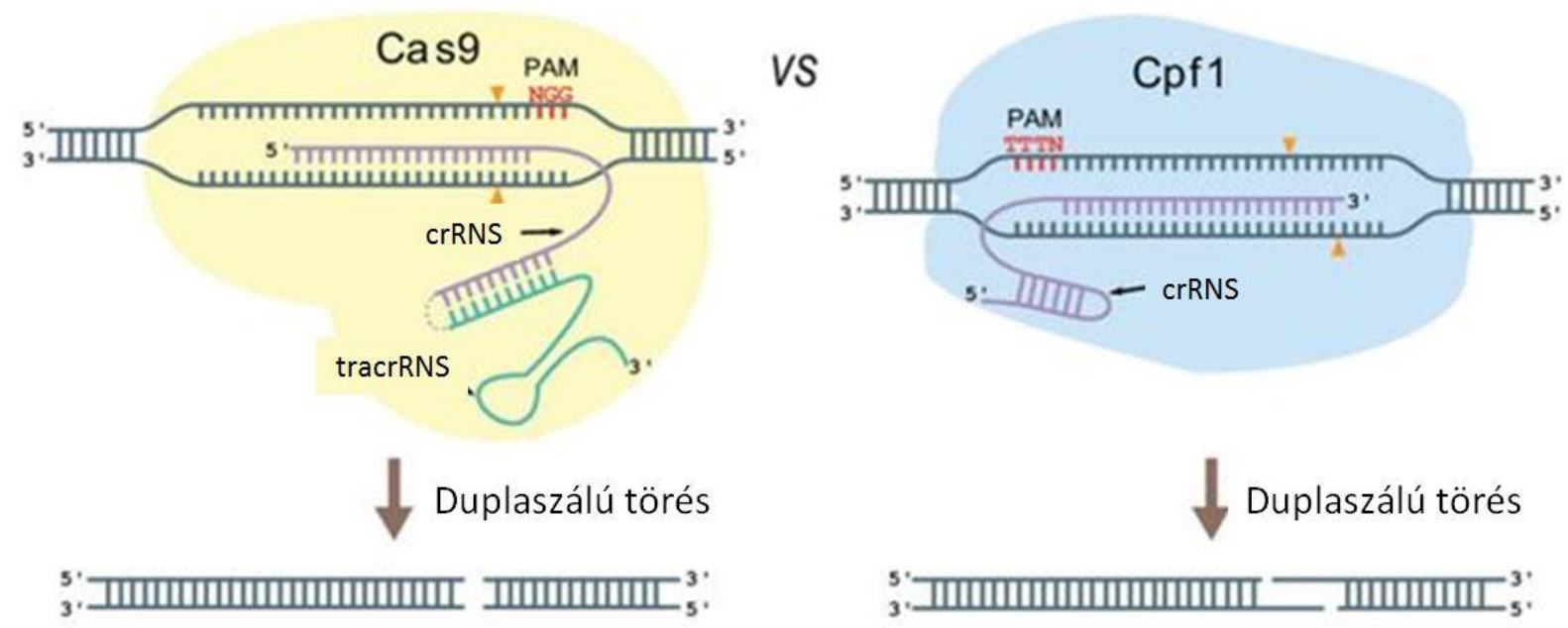

\section{6. Ábra. A Cas9 és a Cas12a nukleázok összehasonlítása}

Az ábra bal oldalán a Cas9-, jobb oldalon a Cas12a fehérje-RNS komplex látható, a fö müködésbéli eltéréseikkel jelölve. A Cas9 tompa véget hoz létre a hasítás után, a Cas12a pedig ragadós véget. A Cas9 specificitását biztosító kis RNS két részből áll és az 5' vég felöli oldala tapad ki a DNS-re, a Cas12a kis RNS-e egy részből áll és a 3' vég felöli oldala tapad ki a DNS-re. Az SpCas9 az NGG PAM-ot, az Lb- és az AsCas12a a TTTN PAM-ot ismeri fel. Míg a Cas9-nél a DNS hasítása a PAM-hoz közel, a Cas12a-nél a PAM-tól távol történik ${ }^{38}$. Ábra forrása: Vanegas és mtsai, 2019 alapján. 
Az előző fejezetben említésre került, hogy a Cas12a nukleázokról többen kimutatták, hogy alacsonyabb off-target-aktivitással bírnak, mint az SpCas9. A genom egészére kiterjedő offtarget elemzések és a célzott mélyszekvenálás azt sugallják, hogy a Cas12a nukleázok csak egy vagy két bázis eltérést tolerálnak, ellentétben az SpCas9-el, amelynél arról számoltak be, hogy akár 5-6 nukleotidos eltérést is tolerálnak a gRNS spacer szekvenciája és a target szekvenciája között ${ }^{34-36}$.

\subsection{A CRISPR/Cas9 müködését befolyásolja a gRNS-ek mennyisége és hossza}

A CRISPR rendszer hatékonyságát többféleképpen is befolyásolhatja a gRNS. Ezek közül az egyik legfontosabb, hogy megfelelő mennyiségű RNS legyen jelen, amely kötődni tud a nukleázhoz. Több csoport kimutatta, hogy a Cas9 müködéséhez elengedhetetlen a guideRNSek megfelelő mennyiségü jelenléte. Különböző alkalmazásokban adott telítési szintig növelve a guideRNS-ek mennyiségét, növelhető a Cas9 hatékonysága, a nem megfelelő mennyiségü gRNS pedig akár teljesen eliminálhatja az aktivitást ${ }^{39-42}$. Emiatt kiemelkedően nagy szükség van arra, hogy a guideRNS expresszió megfelelő hatékonyságú legyen a CRISPR-es alkalmazásoknál.

Számos kutatás szerint a guideRNS-ek mennyiségén túl, azok 5' végének hossza is nagymértékben befolyásolja a Cas9 nukleáz aktivitását. Azt találták, hogy míg a guideRNS-ek 5' végének 1-2 bázissal való rövidítése még nem, addig 3 vagy több bázissal való csonkolása már rontja az SpCas9 nukleáz aktivitását, a 4 bázissal való rövidítés pedig már szinte teljesen eliminálja ${ }^{22,43,44}$. A guideRNS-ek 5' végének rövidítése egyaránt képes hatni az on- és off-target aktivitásra. Fu és mtsai azt találták, hogy az 5' végükön 1-2 nukleotiddal rövidebb guideRNSek off-target hatása kisebb, on-target aktivitása viszont hasonló mértékü, mint a normál hosszúságú gRNS-eké ${ }^{22}$. Tsai és mtsai később szintén megerősítették, hogy a 2-3 nukleotiddal rövidebb gRNS-ek alacsonyabb off-target aktivitással bírnak ${ }^{45}$.

A guideRNS-ek 5' végének azonban nemcsak a rövidítése, de a hosszabbítása is befolyásolhatja az SpCas9 off-target és on-target aktivitását. Többen azt találták, hogy egy plusz G nukleotid hozzáadása a guideRNS 5' végén csökkenti az SpCas9 off-target hatását. Wienert és mtsai azt találták, hogy közben az on-target hatékonyság hasonló volt az 5' G nélküli és a G-vel meghosszabbított guideRNS-ek használatakor ${ }^{46}$. Cho és mtsai viszont megmutatták, hogy a plusz G nukleotidok a guideRNS 5' végén nemcsak az off-target aktivitást csökkentik, de közben az on-target hatékonyság is csökkent ${ }^{47}$. A gRNS-ek expressziója általában az 5', végükön egy G nukleotiddal történik, melynek okait részletesebben a következő fejezetben mutatom be. Ezért vagy olyan targeteket választanak, amelyek guaninnal kezdődnek, vagy a 
guideRNS-eket módosítják a spacerben, hogy a 20. (a 20. pozíció a 2. ábrán látható), vagy 21. pozícióban G legyen. Ez a guideRNS 5' végén helyezkedik el, ami viszont az elöbbiekben bemutatott eredmények szerint módosíthatja a nukleáz hasítási hatékonyságát. Míg azonban az SpCas9 akár a guideRNS-ek 5' végének 1-3 nukleotiddal való rövidítését, valamint az 5' vég plusz G-al való hosszabbítását is jól tolerálja, sőt ezek az off-target hatást is csökkenthetik, addig azok az SpCas9 variánsok, amelyeket úgy módosítottak, hogy magasabb specificitással bírjanak, jóval kevésbé tolerálják ezeket a módosításokat, és az on-target aktivitásuk jelentősen csökkenhet ilyen guideRNS-ek használatával ${ }^{48-50}$.

A guideRNS-eket kémiailag is lehet szintetizáltatni, amellyel pontosan szabályozható az RNS hossz és mennyiség, viszont alkalmazásuk jelentős költségekkel jár. A gRNS-ek előállítására emiatt két költséghatékonyabb módszer terjedt el a gyakorlatban: a T7 promóter segítségével in vitro RNS transzkripció, illetve a különböző organizmusokban más-más kis RNS expresszióra alkalmas promóterek használata.

A fejezetben bemutatott eredmények alapján elmondható, hogy a CRISPR/Cas rendszerek használata során kiemelkedően nagy szükség van arra, hogy a guideRNS-ek hossza és mennyisége megfelelő legyen. Következésképp nagy igény van a gRNS expresszióra gyakran alkalmazott promóterek alapos megismerésére, amellyel fény derülhet arra, hogy melyik promóterrel hogyan érhető el a leghatékonyabb RNS expresszió és a megfelelő hosszúságú gRNS-ek legnagyobb aránya.

\subsection{A CRISPR gRNS-ek expressziójára alkalmazott promóterek}

A CRISPR/Cas rendszert általában vagy plazmidokról expresszálva, vagy in vitro expresszálva és az organizmusba RNS-fehérje komplexet juttatva alkalmazzák. Mind a nukleáz, mind a spacereket tartalmazó kis RNS-ek, akár az in vitro, akár a plazmidról történő expressziójához a legtöbb organizmusban néhány ismertebb promótert használnak. Emlős sejtekben a gRNS-ek expressziójára legyakrabban alkalmazott promóterek az U6, a 7sk és a H1, in vitro a T7. E.coli baktériumokban pedig gyakran használt promóter a J23119.

Több tanulmány szerint a +1 -es pozícióban elhelyezkedő nukleotid befolyásolhatja az RNS expressziót és a transzkripció iniciáció pozícióját, ezáltal az RNS-ek 5 ' végének hosszát is ${ }^{51-53}$. A promóter szekvenciájától downstream elhelyezkedő első bázist nevezik +1 -es pozíciónak, várhatóan innen történik általában az első RNS bázis szintézise a DNS templát alapján.

Az ettől downstream elhelyezkedő pozíciókat a promótertől való távolságuk alapján számozzák és plusszal jelölik. A +1-től upstream lévő pozíciók számozása ugyanilyen módon történik és mínusszal jelölik őket (7. ábra). 
pozíciók

promóter

$-2-1+1+2+3+4 \ldots$

DNS templát

TAATACGACTCACTATAAAGATAGCTGCCGC

\section{7. Ábra. A +1 és a környezetében elhelyezkedő pozíciók számozása}

A promóter szekvenciájától downstream elhelyezkedő első bázist +1 -es pozíciónak nevezik. Tőle upstream mínusszal, downstream pedig plusszal jelölik a pozíciókat. Az ábrán a T7 promóter szekvenciája szerepel.

Az U6, 7sk, H1 promóterek a 3. típusú Polimeráz III (PolIII) promóterek közé tartoznak, melyek a Pol III promóterek között olyan szempontból egyedinek tekinthetők, hogy kizárólag upstream szabályozó elemeket tartalmaznak. Ide tartozik a proximális szekvencia elem (PSE), disztális szekvencia elem (DSE) és a TATA box (8. ábra). Általában jól meghatározott transzkripciós kezdő pozíciójuk van, a +1-es pozíció, valamint egy polyT szekvencia a terminációs szignáljuk. Ennek köszönhetően ezek a promóterek, mint például a 7SK, U6 és a H1 szinte bármilyen kis RNS expressziójára könnyedén felhasználhatók. Ezen promóterek használata széles körben elterjedt kis RNS-ek expresszióra, többek között shRNS-ek expressziójához alkalmazzák őket RNS interferenciánál, valamint guideRNS expresszióra CRISPR/Cas rendszerekhez ${ }^{51}$.

Bár a $\mathrm{H} 1$ promótert is gyakran alkalmazzák, de többen megállapították, hogy az iniciációs pozíciója nem fix, ezért különböző hosszúságú RNS-ek íródnak át róla ${ }^{51,52}$.

Gao és mtsai azt találták, hogy az U6 és a 7sk humán promótereknél befolyásolja az átírás kezdő pozícióját a +1 -es pozícióban elhelyezkedő nukleotid. Mindkét promóterrel akkor pontosan a +1 a transzkripció iniciációjának pozíciója, ha a +1 -ben purin van ${ }^{51}$. Ma és mtsai a humán U6 promóterről 3 különböző, de a +1-ben G-t tartalmazó szekvenciát vizsgáltak meg új-generációs szekvenálással (NGS), néhány ezer readdel. Ök szintén azt találták, hogy ebben az esetben a transzkripció iniciációja majdnem mindig a +1-röl történik ${ }^{52}$. Többen azt találták, hogy az U6 és a 7sk promóternél nemcsak az átírás kezdő pozícióját, de az expressziós szintet is befolyásolja a +1-es pozícióban lévő nukleotid. Az elmúlt években leírták, hogy mindkét promóter +1A-val is hatékonyan használható guideRNS-ek expressziójára ${ }^{49}$. Gao és mtsainak eredményei szerint a +1 -es pozícióban az A és a G nukleotid közel azonos RNS szintet biztosít mindkét promóternél ${ }^{51,54}$. 
Ma és mtsai azt is megállapították, hogy olyan módosított humán U6 promótereknél, amelyeknél a transzkripció iniciáció pozíciójától upstream lévő nukleotidokat módosították restrikciós endonukleáz hasítóhelyek bevitelével, még a +1-es pozícióban purinnal sem fix az iniciáció pozíciója és nemcsak a +1-rôl indul el az átírás ${ }^{52}$.

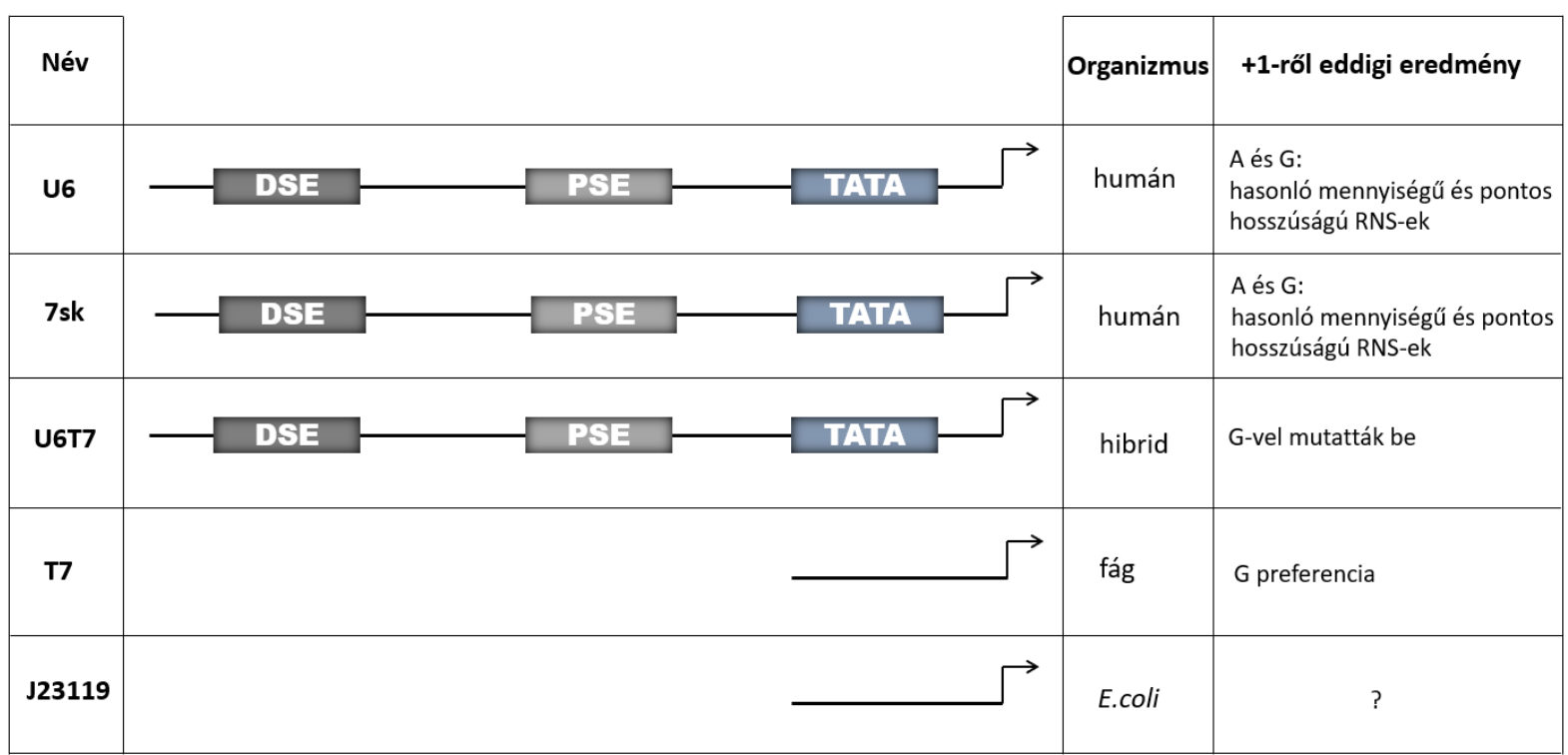

\section{8. Ábra. CRISPR gRNS expresszióra gyakran alkalmazott promóterek}

A táblázatban a CRISPR gRNS-ek expressziójára alkalmazott promóterek közül látható néhány, pár releváns tulajdonságukkal. Középen egy nagyon sematikus ábrázolásuk látható néhány szekvencia elemükkel, úgy, mint a disztális szekvencia elem (DSE, sötétszürke box), proximális szekvencia elem (PSE, világosszürke box) és a TATA box (kék box). Az ábrán szerepel az is, hogy milyen organizmusból származnak, valamint összefoglalva a +1-es pozícióról eddig megjelent irodalmi adatok.

Romanienko és mtsai létrehoztak egy hibrid promótert, melyet U6T7-nek neveztek el, abból a célból, hogy ugyanaz a plazmid konstrukció alkalmas legyen emlős sejtekben és in vitro is kis RNS expresszióra. Az U6T7 hibrid promóter szekvenciájában abban különbözik az U6 szekvenciájától, hogy az U6 utolsó 18 bázispárnyi szekvenciát 3' irányból kicserélték a T7 promóter szekvenciájára, illetve egy bázist megváltoztattak (9. ábra). Megmutatták, hogy emlösökben és in vitro is hatékony expresszió érhető el vele. Az U6T7 promótert a promótertől downstream egy, vagy két G-vel javasolták használni, az eddigi U6 és T7 promóteres publikációk alapján ${ }^{55}$. 


\section{a.hu6 (pX330) \\ TATA -23
TTTATATATcttgtggaaagge
raaacacc
G \\ b.T7 (pDR274) \\ c. hU6T7 \\ taatacgactcactataGgagagaccgagagagggtctc \\ TTTATATATcttgctaatacgactcactataGgagagaccgagagagggtctc}

\section{9. Ábra. Az U6T7 promóter létrehozása}

Az ábrán a T7 promóter szekvenciája, valamint a humán U6 és az U6T7 hibrid promóterek szekvenciarészletei láthatók. Az U6T7 promótert úgy hozták létre, hogy a humán U6 promóter utolsó 18 bázispárnyi szekvenciáját 3' irányból kicserélték a T7 promóter szekvenciájára, illetve egy bázist megváltoztattak ${ }^{55}$. Ábra forrása: Romanienko és mtsai, 2016 alapján.

A T7 RNS polimeráz (T7 RNAP) egy rövid promóterrel rendkívül hatékony expresszióra képes.

A T7 promótert széles körben használják fehérjetermeléshez baktériumsejtekben és nagy mennyiségü RNS előállítására in vitro, mint például aptamerek, ribozimek, siRNS-ek, CRISPR rendszer RNS-ei. Habár a legtöbben a +1-es pozícióban guaninnal használják a T7 promótert, többen leírták, hogy alacsonyabb hatékonysággal in vitro +1 A-val is müködik az expresszió, sőt kevésbé hatékonyan, de primidinről is megy az átírás ${ }^{53,56}$. Ezekben a korai kísérletekben, melyek nem a mai legkorszerübb technikákkal készültek, megmutatták, hogy míg guaninnal általában a +1-ről indul az átírás, addig a többi esetben heterogénebb hosszúságú RNS-ek keletkeznek $^{53}$. Az azonban a szakirodalomban nem konzisztens, hogy a T7 promótert egy darab G-vel (10. ábra), vagy $2^{47,55,57,58}$, vagy akár 3 G-vel érdemes használni ${ }^{58-62}$, és jelenlegi ismereteink szerint e 3 variáció esetében nem történt még olyan átfogó kutatás, amely szisztematikusan összehasonlította volna, hogy melyik variációról mennyi RNS expresszálódik, ezáltal melyik a legalkalmasabb variáció expresszióra.

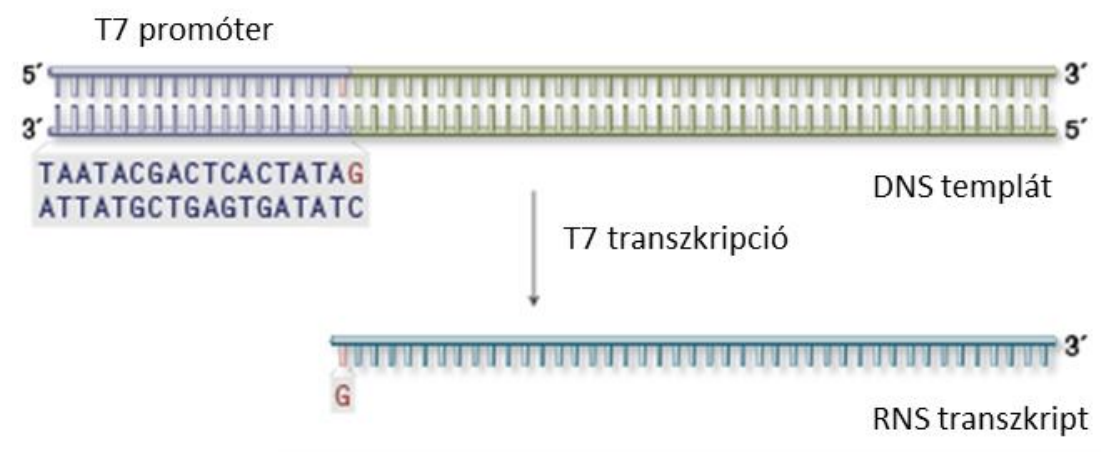

\section{0. Ábra. T7 promóter}

Az ábrán a 77 promóter sematikus ábrázolása látható a szekvenciájával együtt. A promótert általában a promótertől downstream legalább egy $\mathrm{G}$ nukleotiddal használják, amely az ábrán is látható. A TATA szekvenciától downstream elhelyezkedő +1-es pozícióban G van, mely így a promóterről átíródó RNS 5' első nukleotidja is.

Ábra forrása: https://international.neb.com/protocols/2015/11/24/sgrna-synthesis-using-the-hiscribe-quick-t7high-yield-rna-synthesis-kit-neb-e2050 oldal alapján. 
A J23119 promótert CRISPR guideRNS-ek bakteriális expressziójára széles körben alkalmazzák E. coli-ban ${ }^{63-66}$. A J23119 egy mindössze 35 bp hosszú konstitutív promóter szekvencia és az Anderson promóter család legerősebb expresszióra képes tagja ${ }^{67}$. Eddig ismereteink szerint nem látott napvilágot olyan eredmény, amely megmutatta volna, hogy a J23119 promótertől downstream milyen kezdő nukleotidot, vagy nukleotidokat érdemes alkalmazni, úgy, mint ahogy a T7, vagy az U6 és 7sk promótereknél.

Ahogy fent bemutatásra került, a 7sk és az U6 promóterről már ismert, hogy a +1 -es pozícióban A-val is használható. Ennek ellenére általában G-vel alkalmazzák őket ${ }^{49,51,54}$, a T7 promótert pedig minimum egy guaninnal használják ${ }^{47,55,57-62}$. Emiatt az SpCas9 gRNS-ekhez általában olyan targeteket választanak a gyakorlatban, amelyekben a spacer 5' első bázisának megfelelő bázis G, ezáltal a választható targetek köre szükül. Ennek feloldására vagy a guideRNS-eket módosítják a 20., vagy 21.-ik pozícióban G-vel, ami viszont módosíthatja a nukleáz hasítási hatékonyságát ${ }^{46-50}$ (lásd 2.4. fejezet). A promóterek vizsgálatával kapcsolatos eddigi kutatásokban csak a +1 -es pozíciót vizsgálták szisztematikusan, azt is csak a T7, U6 és 7sk promótereknél. Az eddigi eredmények alapján feltételezhető, hogy az összes gRNS expresszióra alkalmazott promóternél befolyásolhatja a +1-es pozíció az expressziót és az RNSek hosszát és elképzelhető, hogy nemcsak a +1 -es pozíció, hanem más pozíciók is.

Abból az okból kifolyólag, hogy a CRISPR/Cas rendszert befolyásolja a gRNS-ek mennyisége és hossza, valamint hasznos lenne a CRISPR-el használható targetek körét bővíteni, felmerül az igény a gRNS-ekre gyakran alkalmazott promóterek alaposabb megismerése. 


\section{Célkitüzések}

Az elmúlt években Zetsche és mtsai megmutatták az As- és az LbCas12a nukleázokról HEK293FT sejtekben, hogy alkalmasak génszerkesztésre ${ }^{37}$. Úttörő publikációjukat követően az elsők között kívántuk megvizsgálni ezen új nukleázok alkalmazhatóságát génmanipulációs eljárásokra más emlős sejtben is. Az SpCas9 mellett kiválasztottunk három olyan Cas9-et, amelyek az SpCas9 után a leggyakrabban alkalmazott nukleázok közé tartoznak: a Staphylococcus aureus-ból (SaCas9) ${ }^{68}$, a Streptococcus thermophilus-ból (StCas9) ${ }^{69}$ és a Neisseria meningitidis-ből (NmCas9) ${ }^{69}$ azonosított nukleázokat és ezek aktivitását kívántuk összehasonlítani a Cas12a nukleázokkal. Az összehasonlításukhoz a korábban publikált GFxFP esszét $^{70}$, illetve annak általunk továbbfejlesztett változatát kívántuk felhasználni. Vizsgálataink során a Cas12a nukleázokkal kapcsolatosan az alábbi kérdésekre kerestük a választ:

1. Alkalmas-e a továbbfejlesztett GFxFP riporter esszé a különböző nukleázok hasítási aktivitásának vizsgálatához?

2. Milyen hatékonysággal képesek az Lb-és AsCas12a nukleázok az SSA javítás indukálására néhány gyakrabban használt Cas9 nukleázhoz képest?

3. Alkalmasak-e az Lb-és AsCas12a nukleázok egy donormolekula HR javítás általi beépítésére a genomba?

A megnövelt specificitású SpCas9 nukleázok széles körü alkalmazhatósága nagymértékben függ attól, hogy képesek-e módosított gRNS-ekkel hatékonyan müködni. A módosított gRNSek használata bevett gyakorlat szekvenciájukban nem G-vel kezdődő targeteknél. A megnövelt specificitású SpCas9 variánsokkal (melyek közül az eCas9-et és az SpCas9-HF1-et vizsgáltuk) kapcsolatosan az alábbi kérdésekre kerestük a választ:

1. Milyen hatással jár a 17, 18 és 19 nukleotid hosszúságú, 5' végükön rövidebb gRNS-ek alkalmazása a megnövelt specificitású SpCas9 variánsok aktivitására?

2. Hogyan befolyásolja az 5' végükön nem G-t, vagy egy nem komplementer G-t tartalmazó gRNS-ek alkalmazása a megnövelt specificitású SpCas9 variánsok aktivitását? 
A CRISPR gRNS-ek expressziójára gyakran alkalmazott promóterek emlősökben az U6, 7sk, in vitro a T7, E.coli-ban a J23119 promóterek. Mivel a Cas nukleázok müködését befolyásolja a gRNS-ek mennyisége és hossza, ezért rendkívül fontos, hogy pontos ismereteink legyenek az alkalmazott promóterekröl. Több tanulmány szerint az, hogy milyen nukleotid követi a promótert, befolyásolhatja az RNS expressziót és a transzkripció iniciáció pozícióját is. Bár néhány általunk vizsgált promóter esetében a promótert követő első nukleotid szerepét már vizsgálták, de a további nukleotidok szerepét még nem. Ezek a +1-es pozícióra irányuló vizsgálatok ráadásul általában nem a jelenleg a kis RNS-ek hosszáról és mennyiségéről legpontosabb képet adó NGS módszerekkel történtek, hanem egyéb kevésbé pontos módszerekkel, illetve az eddig napvilágot látott kevés NGS-el kapott eredményhez nagyon kis számú readet alkalmaztak. A doktori értekezésem alapjául szolgáló kísérleteinkben a kiválasztott promóterek sokkal átfogóbb vizsgálatát kívántuk elvégezni az eddigiekhez képest. Ezt plazmidkönyvtárak létrehozásával és a róluk termelődött RNS-ek nagy readszámú újgenerációs szekvenálásával kívántuk megvalósítani, a promótert követő nemcsak az első, hanem az első 4 nukleotid szerepét megvizsgálva, ezáltal mélyrehatóbban tanulmányozva a megfigyelt promótereket. Doktori értekezésemben a promóterekkel kapcsolatosan az alábbi kérdésekre kerestük a választ:

1. Hogyan befolyásolja az U6 promótertől downstream lévő nukleotidok szekvenciája a transzkripciós iniciációs pozíciót és az RNS expressziót?

2. Az U6 promóter esetében mennyire alkalmasak a +1A-val kezdődő szekvenciák kis RNS-ek expressziójára a $+1 \mathrm{G}$-vel keződődő szekvenciákhoz képest?

3. Hogyan befolyásolja a 7sk promótertől downstream lévő nukleotidok szekvenciája a transzkripciós iniciációs pozíciót és az RNS expressziót?

4. Mennyi RNS expresszálódik a 7sk promóterről az U6 promóterhez képest?

5. Hogyan befolyásolja a T7 promótertől downstream lévő nukleotidok szekvenciája a transzkripciós iniciációs pozíciót és az RNS expressziót?

6. A T7 promóterről egy, kettő, vagy 3 G-vel expresszálódik több RNS?

7. Megváltoztatja-e az U6 promóter módosítása U6T7 hibrid promóterré a transzkripciós iniciációs kezdő pozíciót?

8. Hogyan befolyásolja a J23119 promótertől downstream lévő nukleotidok szekvenciája a transzkripciós iniciációs pozíciót és az RNS expressziót? 


\section{Anyagok és módszerek}

\subsection{Plazmidok létrehozása a Cas12a nukleázok és a megnövelt specificitású SpCas9 variációk vizsgálatához}

A plazmidokat az inaktív nukleázok kivételével (ld. deadLbCas12a) standard molekuláris biológiai technikák alkalmazásával állítottuk elő. Az összes elkészült konstrukciót Sanger szekvenálással ellenőriztük (Microsynth AG). A disszertációban bemutatott eredményekhez az általam, vagy segítségemmel elkészített plazmid konstrukciók létrehozása részletesebben az alábbiak szerint történt.

A pGF-chl-FP plazmid

A pCAG-EGxxFP plazmidot (Addgene: 50716) EcoRV enzimmel emésztettem, melybe egy kloramfenikol rezisztencia gént ligáltam egy a csoportunkban korábban létrehozott plazmidból. A kloramfenikol kazettát PagI és BglII enzimekkel emésztettem, majd a végeket Klenowfragmenttel töltöttem fel.

A pGF-ori-FP plazmid

A pCAG-EGxxFP plazmidot (Addgene: 50716) EcoRV enzimmel emésztettem, melybe a pUC replikációs ORI-t ligáltam egy általam korábban létrehozott plazmidból. A kazettát BcuI és BglII enzimekkel emésztettem, majd a végeket Klenow-fragmenttel töltöttem fel. Ezután kiejtettem az eredeti ORI-t Eco31I és SacI enzimekkel emésztve a vektort.

\section{Spacer klónozások}

A vektorokat vagy Addgene-ről rendeltük, vagy a csoportunkban korábban készültek. Az SpCas9 spacert tartalmazó gRNS expressziós plazmidokat úgy állítottuk elő, hogy a spacer szekvenciát kódoló szintetizált DNS-oligonukleotidokat 4 nt hosszúságú túlnyúlóval egy BbsI restrikciós enzimmel emésztett pmCherry gRNS (Addgene: 80457) plazmidba ligáltuk. Egylépéses emésztés-ligálási protokollt követtünk. A szintetikus DNS oligonukleotidokat hibridizáltuk, és a duplaszálú linkereket $(2,5 \mu \mathrm{M}) 50$ ng plazmiddal, 3 egység BbsI restrikciós enzimmel és 1,5 egység T4 DNS ligázzal összekevertük $500 \mu \mathrm{M}$ ATP-t tartalmazó Green pufferben (Thermo Fisher Scientific). Az elegyet egy órán át $37{ }^{\circ} \mathrm{C}$-on tartottuk, mielőtt kémiailag kompetens, Stable E. coli sejtekbe (NEB) transzformáltuk. Az LB agar lemezen végzett tenyésztés után létrejött kolóniák közül kettőből a plazmidokat restrikciós enzimes emésztéssel teszteltük és a megfelelő klónokat elküldtük szekvenálni. 
Az SaCas9 spacereket ugyanígy klónoztuk, de a vektort (Addgene: Px601) Eco31I enzimmel emésztettük, az St- és NmCas9 spacereket pedig Esp3I-vel. Az As-és LbCas12a plazmidokat szintén így állítottuk elő, és a vektort (Addgene: pTE4396, pTE4398) szintén Esp3I enzimmel emészettük. Az Esp3I emésztésekhez 1 mM DTT-t (Sigma-Aldrich) és Tango puffert használtunk.

\section{dead LbCas12a-et kódoló plazmid}

Az inaktív LbCas12a-et úgy hoztam létre, hogy a 832-es aminosavat alaninra mutáltam. Az LbCas12a vektort (pY016, Addgene: 69988) két fragmensben PCR-el amplifikáltam, és a primerekben a két fragmensre egymással átfedő szakaszok voltak, az egyik primerpár pedig a D832A mutációt hordozta. A két PCR fragmenst E.coli kompetens sejtekbe transzformáltuk, homológ rekombinációs hibajavításon alapuló klónozási eljárásssal ${ }^{71}$.

A Cas12a nukleázok vizsgálataihoz felhasznált további plazmid konstrukciók az Irodalomjegyzékben a 35., a megnövelt specificitású SpCas9 variációkkal kapcsolatos vizsgálatokhoz pedig a 48. számmal jelzett publikációinkban megtalálhatók.

\subsection{Sejttenyésztés}

Az N2a sejteket (Neuro-2a egér neuroblasztoma sejtek, ATCC - CCL-131) és az N2a sejtekből a csoportunkban létrehozott N2a.EGFP sejteket (olyan sejtvonal, amely az EGFP kazetta egyetlen kópiájú integrált példányát tartalmazza, amely a PRNP promóterről expresszálódik), valamint a HEK-293 (Gibco 293-H) sejteket $37^{\circ} \mathrm{C}$-on tenyésztettük párásított atmoszférában, 5\% CO2 tartalom mellett, magas glükóztartalmú Dulbecco’s Modified Eagle’s tápközegben (DMEM). A médiumot 10\% hővel inaktivált magzati szarvasmarha szérummal, $4 \mathrm{mM} \mathrm{L-}$ glutaminnal (Gibco), 100 egység/ml penicillinnel és $100 \mu \mathrm{g} / \mathrm{ml}$ sztreptomicinnel egészítettük ki.

\subsection{A GFxFP vizsgálat}

A GFxFP esszé müködésének részletes bemutatása az 5.1.1-es fejezetben található.

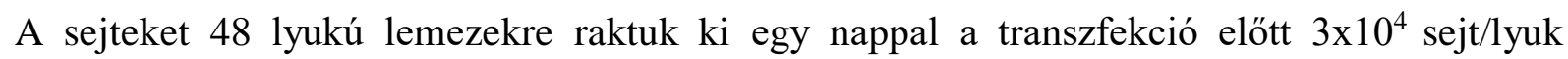
sejtszámmal. 24 órával később körülbelül 40\% -os konfluencia mellett a sejteket a plazmidkonstrukciókkal transzfektáltuk Turbofect reagenssel (Thermo Fisher Scientific), röviden az alábbiak szerint: $250 \mathrm{ng}$ plazmid DNS-t és $1 \mu \mathrm{l}$ Turbofect-et összekevertünk $50 \mu 1$ szérummentes DMEM-ben, és az elegyet 30 percig inkubáltuk szobahőmérsékleten, 
majd hozzáadtuk a sejtekhez. A transzfekciós tápközeget a sejteken 24 órás inkubálás után friss DMEM-re cseréltük ki. Minden mintából három párhuzamos transzfektálást hajtottunk végre. Mindegyik mintával együtt mCherry expressziós plazmidot kotranszfektáltunk a transzfekciós hatékonyság ellenőrzése céljából. A sejteket áramlási citometriával elemeztük két nappal a transzfekció után.

\subsection{Genomi homológ rekombinációs teszt}

N2a sejtekben a PRNP gént célzó crRNS-t tartalmazó As- és LbCas12a nukleázokat kódoló plazmidokat kotranszfektáltuk egy donor plazmiddal, és megfigyeltük a GFP-t expresszáló sejtek számát. A donor molekula egy promóter nélküli GFP nyitott leolvasási keretet (ORF) tartalmazott, amelyet 1000 bp hosszúságú, a PRNP génnel homológ karok fognak közre. A célzott integráció után a PRNP ORF helyébe a GFP ORF kerül, ahol a GFP expresszióját a PRNP gén promótere vezérli.

A sejteket 6 lyukú platekre tettük ki egy nappal a transzfekció előtt 1x10 $10^{5}$ sejt/lyuk sejtszámmal. Másnap, körülbelül 30\% -os konfluencia mellett, a sejteket transzfektáltuk a plazmidkonstrukciókkal Turbofect reagenssel az alábbiak szerint: összesen 4000 ng plazmid DNS-t és $4 \mu \mathrm{l}$ Turbofect-et összekevertünk $400 \mu \mathrm{l}$ szérummentes DMEM-ben, és az elegyet szobahőmérsékleten 30 percig inkubáltuk mielőtt hozzáadtuk a sejtekhez. A sejteken lévő transzfekciós tápközeget 24 órás inkubálás után friss DMEM-re cseréltük ki. Mintánként három párhuzamos transzfektálást hajtottunk végre. Két nappal a transzfekció után a sejteket tripszinnel felszedtük és a következőképpen osztottuk tovább: a sejtek 10\%-át új 6 lyukú lemezekre tettük, a sejtek 90\%-át pedig áramlási citométer segítségével elemeztük. 9 nappal a transzfekció után a mintákat ismételten megmértük áramlási citométerrel.

\subsection{EGFP hasítási teszt}

Az esszé során az N2a.EGFP sejtek EGFP szekvenciáját céloztuk a vizsgált nukleázokkal és az aktivitásuk méréséhez az EGFP jel csökkenését figyeltük meg a kontrollokhoz képest.

Az N2a.EGFP sejteket egy nappal a transzfekció előtt 48 lyukú lemezekre raktuk ki körülbelül $3 \times 10^{5}$ sejt/lyuk sürüséggel. A transzfektálást Turbofect transzfekciós reagenssel végeztük a gyártó által ajánlott protokollnak megfelelően. A transzfekciókat három párhuzamossal hajtottuk végre. Az N2a.EGFP sejteket kétféle plazmiddal együtt transzfektáltuk: SpCas9 expressziós plazmiddal (137 ng), valamint gRNS-t és mCherry-t kódoló plazmiddal (97 ng), 1 $\mu 1$ Turbofect reagenssel, lyukanként. 
A transzfekció hatékonyságát az mCherry-t expresszáló sejtek mCherry szignálja alapján számoltuk ki, melyet 72 órával a transzfekció után mértünk le áramlási citométerrel. Az EGFP szignált $\sim 72$, és 168 órával mértük meg a transzfektálás után. Az EGFP háttérszintjét minden kísérlethez a nem transzfektált sejtek alapján illetve kétféle kontroll felhasználásával határoztuk meg: (i) egy nem EGFP targettel komplementer spacert tartalmazó gRNS-t és egy mCherryt kódoló plazmid valamint egy aktív SpCas9 plazmid kotranszfekciójával; vagy (ii) egy deadSpCas9 expressziós plazmid és egy EGFP-t célzó gRNS-t és mCherry-t kódoló plazmid kotranszfekciójával.

Az EGFP hasítás százalékos arányát az alábbiak szerint számoltuk. Az egyes mintákban az EGFP-pozitív sejtek százalékos arányát levontuk a kontrollokból kapott EGFP pozitív százalékos arányának átlagából, és a transzfekciós hatékonyság értékével súlyoztuk. A transzfekciós hatékonyság értékét a mintákban levő mCherry felhasználásával kaptuk: megmértük az egyes mintákban az mCherry-pozitív sejtek százalékos arányát, és kiszámoltuk azok eltérését az összes transzfektált mintán egyesével az mCherry-pozitív sejtek átlagos százalékos arányától (Átlag) mCherry - Minta mCherry) / (Átlag mCherry). Mindegyik mintánál három párhuzamost dolgoztunk fel és értéküket átlagoltuk.

\section{6. Áramlási citometria}

Az áramlási citometriát az Attune Acoustic Focusing citométerrel (Applied Biosystems) és a BD FACSCanto II-vel (Becton Dickinson Immunocytometry Systems), valamint a CytoFLEX Flow citométerrel (Beckman Coulter) végeztük. Az adatok elemzéséhez Attune Cytometric Software v.2.1.0 és CytExpert 2.0 verziókat használtuk. Az életképes egyes sejteket az oldalsó és a menetirányú fényszórási paraméterek alapján kapuztuk, és az összes kísérlet során összesen 5000-10 000 életképes egyedi sejtet vettünk figyelembe mintánként. Az Attune akusztikus fókuszáló citométer paraméterei: a GFP jel detektálásához 488 nm-es diódás lézert alkalmaztunk az excitációhoz és az emisszióhoz 530/30 nm-es szürőt. Az mCherry jel detektálásához 488 nm-es diódás lézert alkalmaztunk az excitációhoz, 640LP szürőt az emisszióhoz. A CytoFLEX áramlási citométer paraméterei: a GFP fluoreszcencia jelet 488 nmes diódás lézerrel gerjesztettük és 525/40 nm-es szürőt használtunk az emisszióhoz; az mCherry fluoreszcens jelet 638 nm-es diódás lézerrel gerjesztettük és a 660/20 nm-es szürőt használtunk. A BD FACSCanto II áramlási citométer paraméterei: az iRFP670 jelének detektálásához 633 nm-es dióda lézert használtunk és 660/20 nm-es szürőt. 


\subsection{Plazmid könyvtárak létrehozása}

A promóterektől downstream lévő nukleotidok szerepének vizsgálatához olyan plazmid könyvtárakat hoztunk létre, amelyekben a promótert követő első 4 nukleotid randomizált és az RNS-t kódoló régióban további 12 degenerált nukleotid van. Ez a 12 bázispáros bárkód szolgál arra, hogy a különböző hosszúságú és mennyiségü RNS-ek kiindulási mennyiségét, valamint a DNS templátjaik szekvenciáját azonosíthassuk.

Plazmid könyvtár készítés lépései (11. ábra):

1. Plazmid könyvtár vektorainak létrehozása

2. Plazmid könyvtár inszertek létrehozása

3. A vektorok és az inszertek összeillesztése

4. Transzformáció

5. Plazmid könyvtár tisztítása

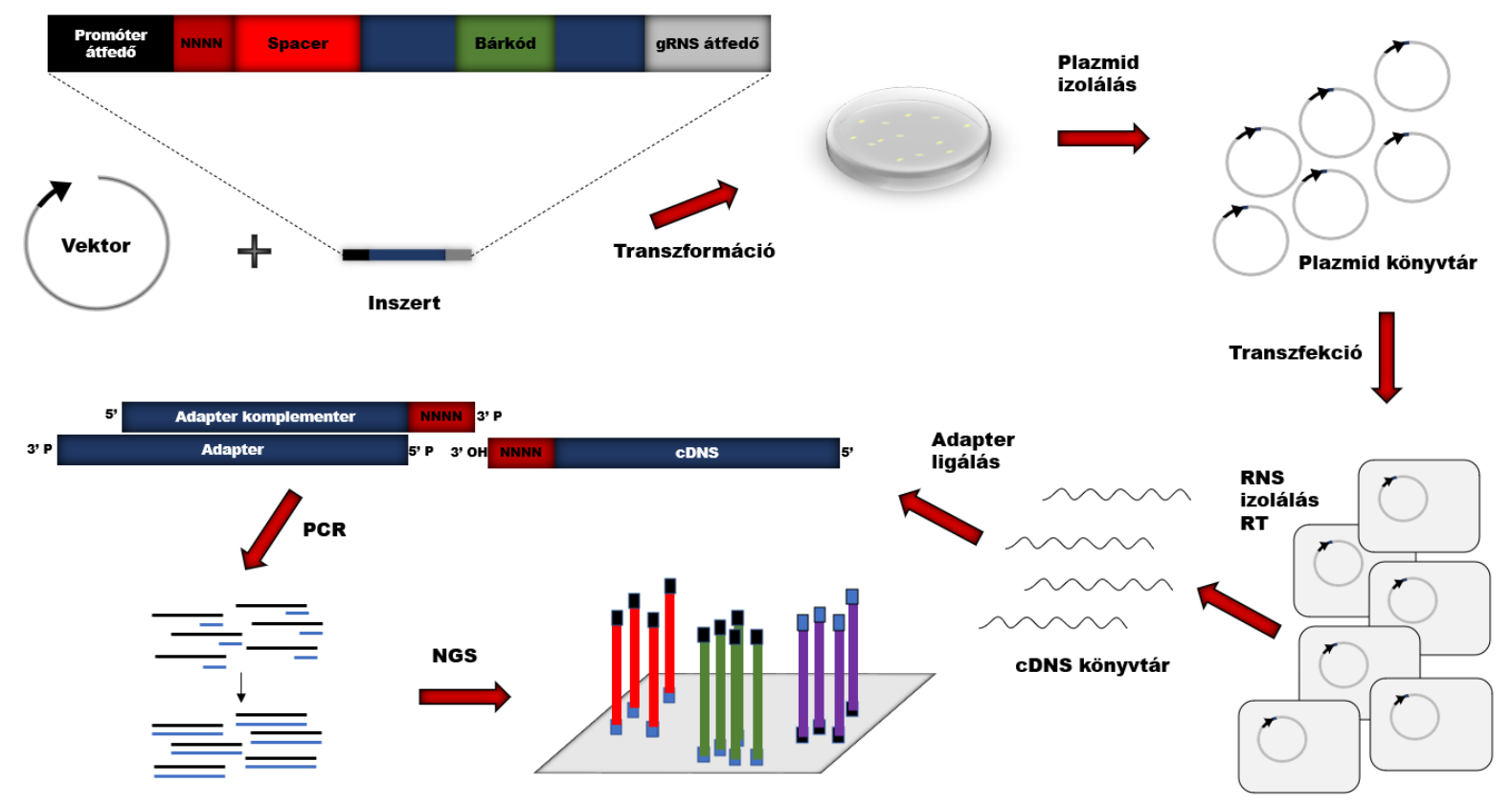

\section{1. Ábra. Promóterek elemzéséhez alkalmazott módszer lépései}

A folyamatábrán a promóterek elemzéséhez alkalmazott módszer lépései láthatóak sematikusan a plazmid könyvtár vektorainak és inszertjeinek összeillesztésétől kezdve az NGS-ig, az emlős promóteres könyvtárakra jellemzően. Először létrehoztuk a plazmid könyvtárakat a vektor és inszert összeillesztésével. Az inszertek két végének szekvenciái megegyeztek a linarizált vektorok végeinek szekvenciájával, azaz a promóter és a gRNS szekvenciáival. Az inszertekben a promótert követő első 4 nukleotid randomizált, valamint a gRNS-ek egy további 12 bázispáros randomizált szakaszt, bárkódot is tartalmaznak. Az összeillesztést a transzformáció követte, amely után a plazmid könyvtárak tisztítása következett. A plazmid könyvtárakat az emlős sejtes promóterek esetében HEK-293 sejtekbe transzfektáltuk. Ezt követte az RNS-ek izolálása, majd a reverz transzkripció egy gRNS-re specifikus primerrel. A cDNS-ek 3' végére adaptereket ligáltunk egyedi módszerrel. Az adapter egy részben duplaszálú DNS molekula. Az adapter mindkét vége és az adapterrel komplementer oligó 3' vége foszforiláltak. A komplementer oligó 3' végén 4 randomizált nukleotid segíti elö a szintén randomizált nukleotidokat tartalmazó cDNS könyvtárakkal való ligálást. A ligátumokat PCR-el amplifikáltuk, majd NGS-el szekvenáltuk, a kiindulási plazmid könyvtárakkal együtt. 


\subsubsection{Plazmid könyvtár vektorainak létrehozása}

A könyvtárakhoz először létre kellett hozni azokat a rekombináns plazmidkonstrukciókat, amelyek a kiválasztott promótereket és az SpCas9 gRNS-t tartalmazzák. Egy PUC plazmid alapú vektor volt a háttér, amely ampicillin rezisztenciát és egy nagy kópiaszámú replikációs origót tartalmazott. Ebbe klónoztam be a különböző promótereket és az SpCas9 guideRNS-t a pX330-U6-Chimeric_BB-CBh-hSpCas9 plazmidból (Addgene: 42230), egy hasítóhelyeket tartalmazó, így könnyedén cserélhető spacerrel. Az U6 promótert a pX330-U6-Chimeric_BBCBh-hSpCas9 plazmidból (Addgene: 42230), a 7sk promótert a ph7SK-gRNA plazmidból (Addgene: 53189) PCR-el amplifikáltam, a J23119 promótert és az U6T7 promóterhez a T7 promóter szekvenciáját pedig linker klónozással építettem be a PUC hátterü plazmidokba. Az összes elkészült konstrukciót Sanger szekvenálással ellenőriztük (Microsynth AG). A plazmid könyvtárak vektorainak létrehozása a fent ismertetett módon előállított plazmidokból PCR-es amplifikálással történt. A PCR-ekhez Q5 polimeráz (NEB) enzimet használtunk, majd DpnI (Thermofischer Scientific) emésztést követően a vektor PCR-t NucleoSpin Gel and PCR Cleanup (Macherey-Nagel) kittel tisztítottuk. A könyvtár vektor amplifikátumaihoz használt primereket az 1. Táblázat tartalmazza.

\begin{tabular}{|c|c|c|}
\hline \multicolumn{3}{|c|}{ Plazmid könyvtár inszertjeinek oligói } \\
\hline Név & Forward primer & Reverz primer \\
\hline U6 spori & TATCTTGTGGAAAGGACGAAACACC & TTTTCAAGTTGATAACGGACTAGCCTTATTTTTAACTTGCTA \\
\hline U6 prp & TATCTTGTGGAAAGGACGAAACACC & TTTTCAAGTTGATAACGGACTAGCCTTATTTTTAACTTGCTA \\
\hline U6 1551 & TATCTTGTGGAAAGGACGAAACACC & TTTTCAAGTTGATAACGGACTAGCCTTATTTTAACTTGGTA \\
\hline 7sk spori & AGCTTGTGCGCCGCTTGG & CCGACTCGGTGCCACTTTTTCAAGTTGATAACGGACTAGCCTTATTTTAACTTGCTA \\
\hline 7sk prp & AGCTTGTGCGCCGCTTGG & CCGACTCGGTGCCACTTITTCAAGTTGATAACGGACTAGCCTTATTTTAACTTGCTA \\
\hline 7sk 1551 & AGCTTGTGCGCCGCTTGG & CCGACTCGGTGCCACTTTTTCAAGTTGATAACGGACTAGCCTTATTTTAACTTGCTA \\
\hline U6T7 spori & CTTGCTAATACGACTCACTATA & CCGACTCGGTGCCACTTTTTCAAGTTGATAACGGACTAGCCTTATTTTAACTTGCTA \\
\hline U6T7 prp & CTTGCTAATACGACTCACTATA & CCGACTCGGTGCCACTTTTTTCAAGTTGATAACGGACTAGCCTTATTTTAACTTGCTA \\
\hline U6T7 1551 & CTTGCTAATACGACTCACTATA & CCGACTCGGTGCCACTTTTTTCAAGTTGATAACGGACTAGCCTTATTTTAACTTGCTA \\
\hline BBaj23119 spori & GTCCTAGGTATAATGCTAGC & CCGACTCGGTGCCACTTTTTTCAAGTTGATAACGGACTAGCCTTATTTTAACTTGCTA \\
\hline BBaj23119 prp & GTCCTAGGTATAATGCTAGC & CCGACTCGGTGCCACTTTTTTCAAGTTGATAACGGACTAGCCTTATTTTAACTTGCTA \\
\hline BBaj23119 1551 & GTCCTAGGTATAATGCTAGC & CCGACTCGGTGCCACTTTTTTCAAGTTGATAACGGACTAGCCTTATTTTAACTTGCTA \\
\hline \multicolumn{3}{|c|}{ Plazmid könyvtár vektorainak oligói } \\
\hline Név & Forward primer & Reverz primer \\
\hline U6 spori & GGTGTTTCGTCCTTTCCACAAGATA & TAGCAAGTTAAAATAAGGCTAGTCCGTTATCA \\
\hline U6 prp & GGTGTTTCGTCCTTTCCACAAGATA & TAGCAAGTTAAAATAAGGCTAGTCCGTTATCA \\
\hline U6 1551 & GGTGTTTCGTCCTTTCCACAAGATA & TAGCAAGTTAAAATAAGGCTAGTCCGTTATCA \\
\hline 7sk spori & GCGCACAAGCTATATAAACCTGAAGGAAGTCT & CTTGAAAAAGTGGCACCGAGTCG \\
\hline 7sk prp & GCGCACAAGCTATATAAACCTGAAGGAAGTCT & CTTGAAAAAGTGGCACCGAGTCG \\
\hline 7sk 1551 & GCGCACAAGCTATATAAACCTGAAGGAAGTCT & CTTGAAAAAGTGGCACCGAGTCG \\
\hline U6T7 spori & TATAGTGAGTCGTATTAGCAAGATATATAAAGCC & CTTGAAAAAGTGGCACCGAGTCG \\
\hline U6T7 prp & TATAGTGAGTCGTATTAGCAAGATATATAAAGCC & CTTGAAAAAGTGGCACCGAGTCG \\
\hline U6T7 1551 & TATAGTGAGTCGTATTAGCAAGATATATAAAGCC & CTTGAAAAAGTGGCACCGAGTCG \\
\hline BBaj23119 spori & GCTAGCATTATACCTAGG & TAGCAAGTTAAAATAAGGCTAGTCCGTTATCA \\
\hline BBaj23119 prp & GCTAGCATTATACCTAGG & TAGCAAGTTAAAATAAGGCTAGTCCGTTATCA \\
\hline BBaj23119 1551 & GCTAGCATTATACCTAGG & TAGCAAGTTAAAATAAGGCTAGTCCGTTATCA \\
\hline
\end{tabular}

1. Táblázat. A plazmid könyvtárak inszertjeihez és vektoraihoz szintetizált primerek szekvenciái

A plazmid könyvtárak inszert és vektor fragmenseit PCR-ekkel amplifikáltuk összeillesztésük előtt, a táblázat az ehhez felhasznált primerek szekvenciáit tartalmazza 5'-3' irányban. 


\subsubsection{Plazmid könyvtár inszertek létrehozása}

Az inszertek tartalmazták az SpCas9 gRNS szekvenciájának olyan módosított szakaszát, ahol a promóter utáni első 4 nukleotid a spacerben és egy további 12 bázispár hosszú, bárkódként használt szekvencia randomizált nukleotidokból áll. Az inszertekhez DNS oligókat szintetizáltattunk, melyek két végükön a vektor plazmidok két végével (promóter, illetve a gRNS) azonos átfedő szekvenciákat tartalmaztak. Az inszert oligók sematikus ábrázolása a 11. ábrán látható, amely összefoglalja a promóterek vizsgálatához alkalmazott módszer további lépéseit is. Az inszerteket, melyekhez a szintetizált oligunukleotidok szekvenciái a 2. táblázatban találhatók, a szintetizált oligókból, PCR-el amplifikálva hoztuk létre, a primerek szekvenciái az 1. táblázatban vannak. A PCR-termékeket gélből izoláltuk, majd NucleoSpin Gel and PCR Clean-up (Macherey-Nagel) kittel tisztítottuk. A PCR-ekhez Q5 polimeráz (NEB) enzimet használtunk.

\begin{tabular}{|c|c|}
\hline Név & Szekvencia 5'-3' \\
\hline U6 spori & GGACTAGCCTTATTTTAACTTGCTANNNNNNNNNNNNTAGCTCTAAAACTGACACGTTCCTTCGGNNNNGGTGTTTCGTCCTTTCCACAAGATA \\
\hline U6 Prp & GGACTAGCCTTATTTTAACTTGCTANNNNNNNNNNNNTAGCTCTAAAACCCCTCATCCCACGATCNNNNGGTGTTTCGTCCTTTCCACAAGATA \\
\hline U6 1551 & GGACTAGCCTTATTTTAACTTGCTANNNNNNNNNNNNTAGCTCTAAAACGCTTGTGCCCCAGGATNNNNGGTGTTTCGTCCTTTCCACAAGATA \\
\hline 7sk spori & GGACTAGCCTTATTTTAACTTGCTANNNNNNNNNNNNTAGCTCTAAAACTGACACGTTCCTTCGGNNNNGAGGTACCCAAGCGGCGCACAAGCT \\
\hline 7sk Prp & GGACTAGCCTTATTTTAACTTGCTANNNNNNNNNNNNTAGCTCTAAAACCCCTCATCCCACGATCNNNNGAGGTACCCAAGCGGCGCACAAGCT \\
\hline 7sk 1551 & GGACTAGCCTTATTTTAACTTGCTANNNNNNNNNNNNTAGCTCTAAAACGCTTGTGCCCCAGGATNNNNGAGGTACCCAAGCGGCGCACAAGCT \\
\hline U6T7 spori & GGACTAGCCTTATTTTAACTTGCTANNNNNNNNNNNNTAGCTCTAAAACTGACACGTTCCTTCGGNNNNTATAGTGAGTCGTATTAATCGCC \\
\hline U6T7 Prp & GGACTAGCCTTATTTTAACTTGCTANNNNNNNNNNNNTAGCTCTAAAACCCCTCATCCCACGATCNNNNTATAGTGAGTCGTATTAATCGCC \\
\hline U6T7 1551 & GGACTAGCCTTATTTTAACTTGCTANNNNNNNNNNNNTAGCTCTAAAACGCTTGTGCCCCAGGATNNNNTATAGTGAGTCGTATTAATCGCC \\
\hline BBaj23119 spori & GGACTAGCCTTATTTTAACTTGCTANNNNNNNNNNNNTAGCTCTAAAACTGACACGTTCCTTCGGNNNNACTAGTATTATACCTAGGACTGAGC \\
\hline BBaj23119 Prp & GGACTAGCCTTATTTTAACTTGCTANNNNNNNNNNNNTAGCTCTAAAACCCCTCATCCCACGATCNNNNACTAGTATTATACCTAGGACTGAGC \\
\hline BBaj23119 1551 & GGACTAGCCTTATTTTAACTTGCTANNNNNNNNNNNNTAGCTCTAAAACGCTTGTGCCCCAGGATNNNNACTAGTATTATACCTAGGACTGAGC \\
\hline
\end{tabular}

\section{Táblázat. A plazmid könyvtár inszertjeihez szintetizált oligonukleotidok szekvenciái}

A plazmid könyvtárak inszertjeihez oligonukleotidokat szintetizáltattunk, ezek szekvenciái láthatóak a táblázatban 5'-3' irányban.

\subsubsection{A vektorok és inszertek összeillesztése}

Az inszertek és a vektorok összeillesztését Gibson klónozási technikával végeztük ${ }^{72}$, amely NEBuilder HiFi DNA Assembly Master Mix-el (NEB) történt, a protokoll szerint, $50{ }^{\circ} \mathrm{C}$-on 1 órán át. Az inszert:vektor moláris aránya 3:1 volt.

\subsubsection{Transzformáció}

A plazmid könyvtárakat ultrakompetens Dh5alpha (NEB) sejtekbe mértem, majd jégen 15 percig inkubáltam. Ezután hősokkoltam $42{ }^{\circ} \mathrm{C}$-on 1 percig, amit $400 \mathrm{ml} \mathrm{LB}$ rámérése után 15 perc rázás követett $37^{\circ} \mathrm{C}$-on. Az inkubáció után kiszélesztettem a könyvtárakat és egy éjszakán át $37^{\circ} \mathrm{C}$-on inkubáltam. 


\subsubsection{Plazmid könyvtárak tisztítása}

A könyvtárak telepszámainak becslése után LB-vel mostam le a lemezeket, melyekből ezután GenElute HP Plasmid Miniprep (Sigma-Aldrich) kittel tisztítottam ki a plazmid könyvtárakat. Az összes könyvtárat Sanger szekvenálással ellenőriztük (Microsynth AG).

\subsection{A cDNS könyvtárak létrehozása}

A cDNS könyvtár készítés lépései (11. ábra):

4.8.1. Emlős sejtek RNS könyvtárainak létrehozása

4.8.2. Bakteriális promóteres RNS könyvtárak létrehozása

4.8.3. In vitro $\mathrm{T} 7$ transzkripció

4.8.4. Reverz transzkripció

\subsubsection{Emlős sejtek RNS könyvtárainak létrehozása}

Az U6, 7sk és U6T7 emlős promóteres plazmid könyvtárakat HEK-293 sejtekbe transzfektáltuk. A sejttenyésztésről további információ a 4.2. fejezetben található. A sejteket T75 méretű flaskákban szaporítottam fel, a kiindulási sejtszám 4 millió/flaska volt és a sejtek a kirakás után 24 órával kerültek transzfektálásra. A transzfekciós ágens Jetfect reagens (Biospirál-2006. Kft.) volt, egy flaskára $15 \mu \mathrm{g}$ plazmidkeverék került, amely a plazmidkönyvtárból és egy kontroll GFP-t expresszáló plazmidból állt 9:1 arányban. Transzfekció után 48 órával a transzfekciós hatékonyságot a sejtek 10\%-ából citometriásan az Attune Acoustic Focusing citométerrel, az Attune Cytometric szoftverrel ellenőriztük (lásd 4.6. fejezet). A sejtek kirakása után 72 órával a sejtek 90\%-ából RNazol (Molecular Research Center) segítségével tisztítottuk az RNS-t. Az RNS-ek integritását minden mintánál gélelektroforézissel ellenőriztük. Minden plazmid könyvtárról 3 párhuzamos RNS minta készült. Az emlős sejtes promóterek vizsgálatához alkalmazott módszer lépései sematikusan a 11. ábrán láthatók.

\subsubsection{Bakteriális promóteres RNS könyvtárak létrehozása}

A bakteriális promóteres könyvtárakat tartalmazó Dh5alpha sejtekből 30\%-os glicerines stockot készítettünk, melyet $-20{ }^{\circ} \mathrm{C}$ - on tároltunk. A stockból $100 \mu \mathrm{l}$-t $10 \mathrm{ml}$ ampicillint tartalmazó LB médiumban egy éjszakán át $37^{\circ} \mathrm{C}$-on rázatva inkubáltam. Az RNS-eket másnap RNazol (Molecular Research Center) segítségével izoláltam, a sejtszám körülbelül 1x10 ${ }^{9}$ volt. Az RNS-ek integritását minden mintánál gélelektroforézis segítségével ellenőriztem. Minden plazmid könyvtárról 3 párhuzamos RNS minta készült. 


\subsubsection{In vitro $\mathrm{T} 7$ transzkripció}

Az U6T7 plazmid könyvtárakról a 3. táblázatban megadott primerekkel amplifikáltuk a T7 promótert és a guideRNS-t. Az amplifikátumokat gélből izoláltuk, majd NucleoSpin Gel and PCR Clean-up (Macherey-Nagel) kittel tisztítottuk. A templát PCR-ekről in vitro TranscriptAid T7 High Yield Transcription Kit segítségével expresszáltam az RNS-eket. Az RNS-eket az RNA Clean \& Concentrator (Zymo) RNS tisztító kittel izoláltam. Az RNS-ek integritását minden mintánál gélelektroforézissel ellenőriztük. Minden plazmid könyvtárról 3 párhuzamos RNS minta készült.

\footnotetext{
Név Szekvencia 5'-3'

T7 Forward CTTGCTAATACGACTCACTATA

T7 Reverz AAAAAAGCACCGACTCG
}

\section{Táblázat. Az in vitro T7 RNS transzkripció templátjához felhasznált primerek szekvenciái}

A táblázatban a T7 promótereket és a gRNS-eket tartalmazó kazetta PCR-es amplifikálásához felhasznált primerek láthatók 5'-3' irányban. A primerekkel amplifikált PCR-ek szolgáltak templátul az in vitro transzkripcióhoz.

\subsubsection{Reverz transzkripció}

A reverz transzkripcióhoz Maxima $\mathrm{H}$ minus first strand cDNA synthesis kit with dsDNAse (Thermo Scientific) enzimet használtuk. A reverz transzkripciós primer a következő volt: 5, GCCACTTTTTCAAGTTGATAACGGAC 3'. A reakció $65^{\circ} \mathrm{C}$-on 1 órán át zajlott.

\subsection{Adapterek ligálása a cDNS-re}

A cDNS 3' végére az adaptert T4 DNS ligáz (Thermo Fischer Scientific) segítségével ligáltuk. Az adapter egy részben duplaszálú DNS molekula volt, melyet a ligálás előtt hibridizáltunk. Az adapter 5' és 3' vége és az adapterrel komplementer oligó 3' vége foszforilációval kerültek szintetizálásra a Sigma-Aldrich által. A ligálás $37{ }^{\circ} \mathrm{C}$-on, 1 órán át történt, 20\%-os PEG8000 (Thermo Fischer Scientific) koncentráció mellett, T4 DNS ligáz (Thermo Fischer Scientific) enzim segítségével (lásd részletesebben a 18. ábrán és az 5.3.2. fejezetben). 


\subsection{NGS}

A plazmid könyvtárakat és a cDNS könyvtárakat Illumina Nextera túlnyúlókat tartalmazó specifikus primerekkel amplifikáltuk, majd a termékeket az NGS indexekkel meghosszabbított primerekkel amplifikáltuk egy következő PCR-el. Az első körös PCR primerek megtalálhatók a 4. táblázatban. A 2. PCR után a minták koncentrációit Qubit dsDNA HS (Thermo Fischer Scientific) kit segítségével határoztuk meg, és elvégeztük a megfelelő koncentrációkban történő összekeverést (pooling) az NGS-hez. A PCR-ket a BGI szekvenálta HiSeq X10-el, pair end technológiával. A szekvenálás minőségét a FastQC v.0.11.8 segítségével ellenőriztük. Az adapterek szekvenciáit Trimmomatic 0.38-mal trimmeltük a readekről. A forward és reverz readeket a FLASH-1.2.11 programmal párosítottuk.

\subsection{Programozás}

Az előző pontban leírt lépéseket követően a további adatfeldolgozást Python-ban végeztük, mely az alábbi főbb lépésekből állt:

1. A gRNS szekvenciáját tartalmazó readek indexek szerinti szétválogatása

2. A kapott readek illesztése a gRNS szekvenciájára

3. Bárkód szekvenciák dinamikus felismerése (readen belül változó pozícióban van a bárkód)

4. 4N szekvenciák dinamikus felismerése (readen belül változó pozícióban van a 4N)

5. RNS és plazmid könyvtárak készítése (4N+bárkód+sokaság)

6. Readszám alapján szürés

7. RNS könyvtárak normalizálása a DNS könyvtárral

8. RNS könyvtárak 4N és különböző hosszúság szerinti szétválogatása és összeszámolása A további kiértékelést Microsoft Excel segítségével végeztük el.

\subsection{Statisztika}

A promóterek és a megnövelt specificitású SpCas9 variációk vizsgálatához a statisztika a következőképp történt. Egyszempontos varianciaanalízist használtunk, melyhez Levenepróbával ellenőriztük a varianciakülönbségeket. Szignifikáns Levene-próba esetén a Welch variancianalízist használtuk a klasszikus ANOVA helyett. A minták különbségeink összehasonlításához ANOVA alkalmazásakor Tukey, szignifikáns Levene próba után pedig Games-Howell post-hoc teszteket végeztünk el. A promóterek vizsgálatához IBM SPSS v25 programmal készítettük el a statisztikát, a megnövelt specificitású SpCas9 variációk tesztelésével kapcsolatos statisztika pedig R 3.4.1-ben készült. 


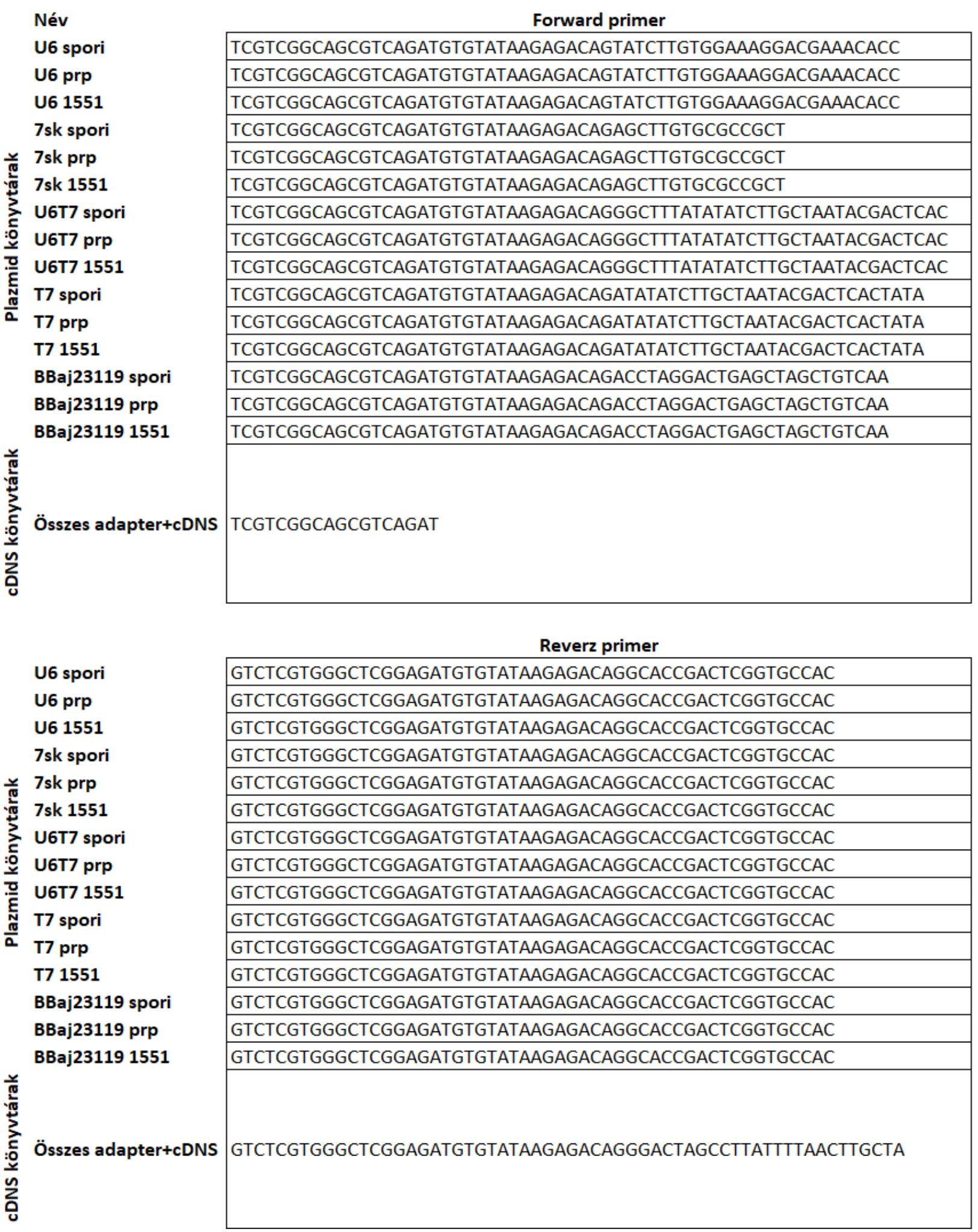

4. Táblázat. A könyvtárak első NGS PCR primerei

A plazmid könyvtárakat és az adapterrel ligált cDNS könyvtárakat Illumina Nextera túlnyúlókat tartalmazó specifikus primerekkel amplifikáltuk, melyek a táblázatban láthatók 5'-3' irányban. 


\section{Eredmények}

\subsection{Cas12a nukleázok vizsgálata}

\subsubsection{A GFxFP esszé módosítása}

A fejezet összes eredménye, valamint ezekkel kapcsolatos további eredmények az Irodalomjegyzékben a 35. számmal hivatkozott publikációnkban található.

Az AsCas12a és LbCas12a nukleázok aktivitásának vizsgálatához a Mashiko és mtsai által publikált fluoreszcens riporter assay-t használtuk ${ }^{70}$, amely a 12. ábra a, részén látható. A GFP riporter plazmidban egy GFP-szekvencia 5' és 3' fragmentumát elválasztja egymástól két 480 bázispár hosszúságú ismétlődő szekvencia, amely a GFP szekvencia középső részlete. Az expressziós kazettát egy CAG promóter hajtja és egy SV40 (Simian Vacuolating Virus 40) polyA jel zárja le. Az első GFP fél egy STOP kodonnal fejeződik be, ezáltal erről a szakaszról nem észlelhető GFP fluoreszcencia. A második GFP félnek nincs sem Kozak szekvenciája, sem ATG kodonja. A nukleáz targetét egy poliklónozó helyre (MCS) kell klónozni a két GFP fél között. A nukleázok target szekvenciáját a két, ismétlődő szekvencia közé helyezve a nukleáz hasításakor létrehozott kettős szálú DNS-törés a homológ rekombinációs hibajavítás egyik altípusával, a single strand annealing DNS javító mechanizmussal (SSA) javítódik (ld. 2.1. fejezet). Ennek az esszének, amelyet „GFxFP assay-nek” hívunk az az előnye például egy genomi pozíciókat célzó esszével szemben, hogy bármilyen nukleáz DNS hasítási hatékonyságának mérését lehetővé teszi egy specifikus target hasításával, miközben a hasítás hatékonyságát nem befolyásolják külső tényezők. Ilyenek a genomi környezet, a target szekvencia epigenetikus állapota, vagy a target relatív távolsága a homológ karoktól. 

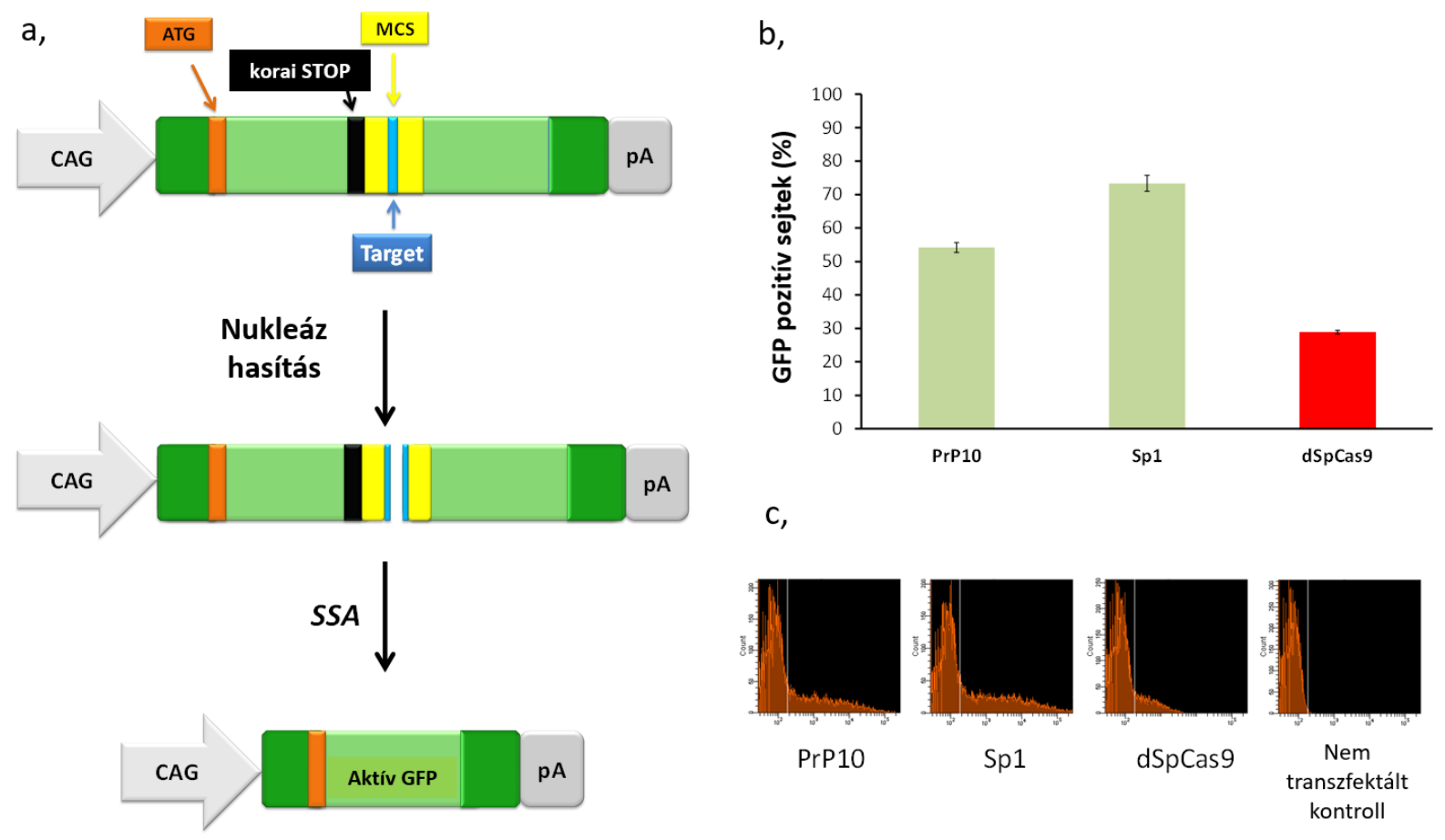

C,

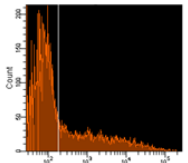

PrP10

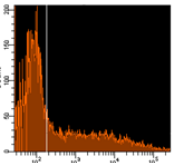

Sp1

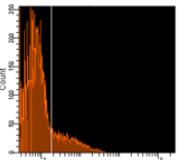

dSpCas 9

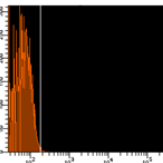

Nem transzfektált kontroll

\section{2. Ábra. GFxFP riporter esszé}

a, Az ábra a nukleázok aktivitásának megfigyelésére alkalmazott riporter esszé elvét ábrázolja. A két GFPfélszekvencia zölden van jelölve. Ezek mindegyike tartalmaz egy egyedi szegmenst (sötétzöld) és egy átfedö, azonos szekvenciát tartalmazó szegmenst (világoszöld). Az expressziós kazettát egy CAG promóter hajtja (szürke nyíl), és egy SV40 (Simian Vacuolating Virus 40) polyA jel (pA, szürke doboz) zárja le. Az első GFP fél egy STOP kodonnal fejeződik be (fekete jel). A nukleáz targetét (kék téglalap) egy poliklónozó helyre (MCS, sárga) kell klónozni a két GFP fél között. A nukleáz hasításával a célszekvenciában létrehozott kettős szálú DNS-törést az ismétlődő szekvenciák által irányított SSA javítás javítja. Ennek eredményeként egy ép GFP szekvencia jön létre, amelyből egy aktív GFP íródik át. b, A GFP fluoreszcenciát mutató sejtek százalékos aránya. A Prp10 és Sp1 oszlopok azt mutatják meg, hogy hány \%-ban tartalmaztak GFP-t azok a sejtpopulációk, amelyek a Prp10, vagy Sp1 targeteket tartalmazó GFxFP plazmidokkal és a megfelelö gRNS-eket és Cas9-et kódoló plazmidokkal kerültek transzfektálásra. A dSpCas9 olyan sejteket takar, amelyeket inaktív SpCas9-et expresszáló vektorral transzfektáltunk. Az értékek kiszámításához iRFP670 szignált használtunk a transzfekciós hatékonyság mérésére és a GFP értékeket erre normalizáltuk. A hibasávok az n=3 független transzfekció során mért százalékok szórását mutatják be. c, A GFP fluoreszcencia intenzitások reprezentatív hisztogramjai, amelyeket a Prp10, Sp1, dSpCas9 és egy nem transzfektált sejtpopuláció mintáinak áramlási citometriás elemzésével mértünk a transzfekció utáni második napon ${ }^{35}$.

Ennek a vizsgálati rendszernek a teszteléséhez SpCas9-et használtunk két target szekvenciával (PrP10- és Sp1-ként fogok rájuk utalni a következőkben). Az Sp1 vagy PrP10 targetet tartalmazó GFxFP plazmidokat N2a egér neuroblasztóma sejtekbe kotranszfektáltuk, SpCas9et, a megfelelő guideRNS (gRNS)-t és iRFP670 fluoreszcens fehérjét expresszáló plazmidokkal. Kontrollként inaktív dSpCas9-et expresszáló vektort használtunk a sejtek transzfektálására. A fluoreszcens sejtek számát két nappal a transzfekció után mértük le. Az iRFP670 a transzfekció hatékonyságának nyomon követését segítette elő, míg a kontroll háttér feletti GFP szint növekedés mérése a hasítási hatékonyság vizsgálatát.

Az Sp1-target 73\% -ot, míg a PrP10-target 54\% -os fluoreszcens sejtszámot eredményezett a transzfektált populációkban (12. ábra b). 
Meglepő módon a kontroll populáció is figyelemre méltó, körülbelül 30\% -os GFP-pozitivitást mutatott. Látszólag a plazmidok egy részében a homológ szekvenciák közötti rekombináció a nukleáz hasítása nélkül is megtörtént. Ezután, annak érdekében, hogy megfigyelhessük a potenciális rekombinációs eseményeket, amelyek már a plazmid kezelése során megtörténhetnek a baktériumsejtekben, vagy kloramfenikol rezisztencia gént (pGF-chl-FP, 13. ábra a), vagy a plazmid replikációs origóját (pGF-ori-FP) klónoztam be a GFP fragmensek homológ szekvenciái közötti régióba. A baktériumsejtekből végzett plazmid izolálás után egyik esetben sem észleltünk rekombinált frakciót (pGF-ori-FP és pGF-chl-FP plazmidok), amikor restrikciós enzimes emésztéseket követően vizsgáltuk őket agaróz gélelektroforézissel. Ez arra utal, hogy egy ilyen populáció, ha létezik is, kevesebb, mint $1 \%$.

Ezután ezekbe a vektorokba is beklónoztuk a korábban használt Sp1 és PrP10 target szekvenciákat, és megvizsgáltuk az SpCas9 által indukált GFP javítást N2a sejtekben. A kloramfenikol kazettát tartalmazó GFxFP plazmiddal az aktív SpCas9-tartalmú mintákban a fluoreszcens sejtek százalékos aránya kevesebb volt, mint a kloramfenikol nélkül alkalmazott GFxFP-vel. Amikor az inaktív dSpCas9-et expresszáló vektort pGF-chl-FP plazmiddal kotranszfektáltuk, a GFP-pozitív sejtek továbbra is kimutathatók voltak, bár alacsonyabb százalékban, mint a módosítatlan eredeti plazmid, a GFxFP esetében (13. ábra b). Ez arra utal, hogy a funkcionális GFP-molekulák még a pGF-chl-FP-vel módosított plazmidok egy részében is expresszálódtak a nukleáz hasítása nélkül is. A nukleáz hasítása mellett bekövetkező GFP jel csökkenése nemcsak a baktériumsejtekben már rekombinált plazmidok arányának csökkenésével magyarázható, hanem a két GFP fél csökkent rekombinációs képességét is tükrözi, mivel a köztük lévő távolságot növeli a kloramfenikol rezisztencia kazetta. A viszonylag magas háttér-GFP-fluoreszcencia eredete nem teljesen tisztázott, de azt feltételeztük, hogy az N2a-sejtekben természetesen előforduló kettős szálú törések kissé magas szintjéből származhat. Ennek kiderítésére anti-H2AX festést végeztünk többféle sejten, amellyel azt kaptuk, hogy az N2a és a HEK-293T sejtek összehasonlítható, de figyelemre méltóan magasabb szintű DNS kettős száltörést mutatnak, mint a HeLa sejtek. Hasonló eredményeket találtunk a pGF-ori-FP plazmiddal is, majd ezt a plazmidot használtuk a további kísérletekben. 

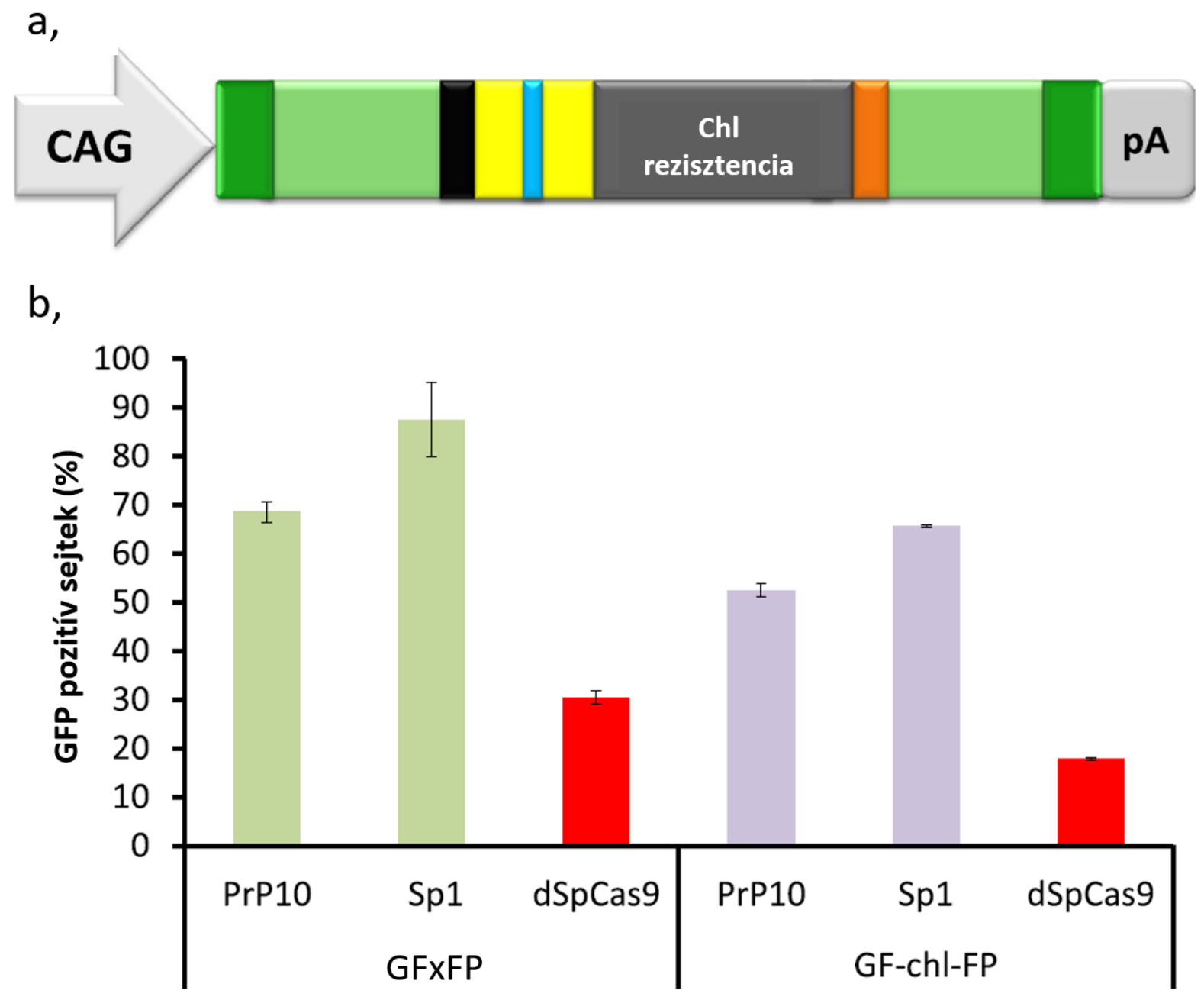

13. Ábra. A kloramfenikol rezisztencia gén integrációja csökkenti a fluoreszcens sejtek számát a GFxFP vizsgálatban

a, A GFxFP kazetta sematikus ábrázolása, a 12. ábrához hasonló módon.

A kloramfenikol rezisztencia gén egy sötét szürke doboz középen a GFP-fél fragmensek homológ szekvenciái között. b, A GFP pozitív sejtek százalékos arányának összehasonlítása, ha a riporter esszét az eredeti vagy (GFxFP, zöld oszlopok) vagy a kloramfenikol rezisztencia génnel kiegészített (GF-chl-FP, lila sávok) GFxFP plazmidokat tartalmaz. Mindegyik esetben két targetet teszteltünk, a PrP10-et és az Sp1-et, az SpCas9 nukleáz és a megfelelö gRNS-eket kódoló plazmidok kotranszfekciójával N2a sejtekben. Kontrollként inaktív SpCas9-et használtunk mindkét esetben (piros oszlopok, dSpCas9). Az értékeket a transzfekciós hatékonysággal normalizáltuk, iRFP670 fluoreszcencia alapján, amelyet transzfekciós kontrollként használtunk. A hibaoszlopok a százalékos értékek átlagainak szórását mutatják. $\mathrm{N}=3$ volt. A kloramfenikol kazetta integrációja csökkentette a fluoreszcens sejtek számát mind az aktív, mind az inaktív SpCas9-el ${ }^{35}$.

\subsubsection{Az As- és LbCas12a hatékonyan indukálja a GFP kazetta javítását a GFxFP}

\section{esszében}

Az As- és LbCas12a nukleázok hatékonyságának tesztelésére emlös sejtekben HR javítást indukáltunk 20 genomi target szekvenciát kiválasztva. Ezek három egér prionfehérje család gént céloztak meg: PRNP, SPRN és PRND. A targeteket a GFxFP plazmidba, a megfelelő spacereket az AsCas12a- és LbCas12a-crRNS-eket is kódoló plazmidokba klónoztuk. 
A tesztelés során mind az As-, mind az LbCas12a hatékonyan indukálta a GFP kazetta javítását mind a 20 targettel, minden esetben több, mint 10\% fluoreszcens sejtet eredményezve a kontrollhoz képest, megerősítve ezen Cas12a nukleázok aktivitásának robusztusságát (nincs ábrázolva).

Számos Cas9 nukleázt jellemeztek annak érdekében, hogy a legszélesebb körben alkalmazott SpCas9-hez hasonlóan használható nukleázt találjanak. Ezekből kiválasztottunk hármat, amelyek az SpCas9 után a leggyakrabban alkalmazott nukleázok közé tartoznak: a Staphylococcus aureus-ból (SaCas9) ${ }^{68}$, a Streptococcus thermophilus-ból (StCas9) ${ }^{69}$ és a Neisseria meningitidis-ből (NmCas9) ${ }^{69}$ azonosított Cas9 nukleázokat, és összehasonlítottuk robusztusságukat az AsCas12a és LbCas12a nukleázokkal, 5-5 különböző és nukleázonként eltérő targetek felhasználásával. Azért alkalmaztunk különböző targeteket, mert létező genomi pozíciókat kívántuk megvizsgálni, amelynek eredményeit későbbi kísérletekben is fel kívántunk használni és a targeteket a PAM szekvenciák alapján választottuk ki. A targeteket véletlenszerüen választottuk ki, azaz anélkül, hogy a nukleázok szekvencia specifitására vonatkozó előzetes ismereteket alkalmaztunk volna. Az SpCas9 esetében ez nem így történt, itt kihasználtuk a gRNS-hatékonyság-jósló eszközök létezését: sgRNA designer- t ${ }^{73}$ és az sgRNA scorer-t $1.0^{74}$, és az általuk közepes, vagy annál jobbnak ítélt targeteket választottunk ki. A többi nukleázhoz ekkor még nem léteztek ilyen predikciós programok. Az összes targetet a GFxFP riporter rendszerrel teszteltük, amely lehetővé teszi a nukleázok aktivitásának közvetlenebb összehasonlítását kizárva azt, hogy a targetek homológ karoktól lévő távolsága, vagy a genomi környezet befolyásolja a hasítás hatékonyságát. Az összes mintát mCherry expressziós vektorral együtt transzfektáltuk, és az eredményeket az mCherry pozitív populáción belül elemeztük. A negatív kontrollok GFP fluoreszcenciáját inaktív SpCas9-et expresszáló vektor alkalmazásával mértük, és a kapott értékeket kivontuk minden egyes minta értékéből. Minden esetben három párhuzamos transzfektálást hajtottunk végre. Eredményeink alapján ebben a vizsgálatban mindkét Cas12a nukleáz ugyanannyira, vagy hatékonyabban indukálta az SSA hibajavítást átlagosan, mint három vizsgált Cas9 (14. ábra). Az LbCas12a az 5 különböző target alapján átlagosan 24\% az AsCas12a 15\%-os GFP szint növekedést eredményezett a kontrollhoz képest, szemben a SaCas9 13\%, StCas9 9\% és az NmCas9 3\% -os eredményéhez képest. A várakozásoknak megfelelően az SpCas9 mutatta a legerősebb aktivitást, bár ehhez hozzájárulhatott a predikciós programok használata is. Ezek az eredmények arra utalnak, hogy a Cas12a nukleázok fontos helyet foglalnak el az SpCas9 mellett a genomszerkesztő eszközök palettáján. 


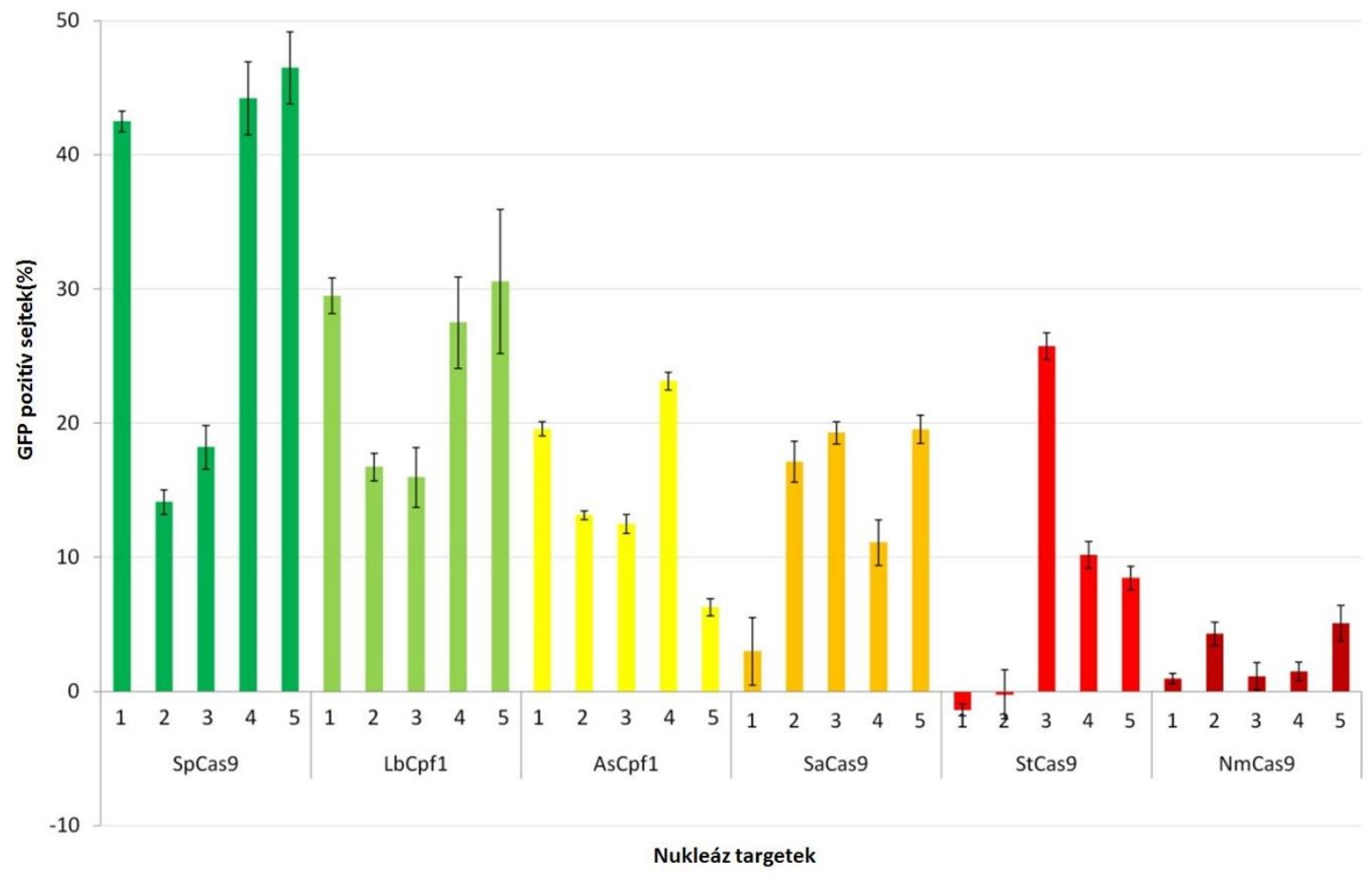

14. Ábra. A különböző nukleázok aktivitásának összehasonlítása GFxFP-vel

A GFP háttér feletti GFP pozitív sejtek százalékos aránya, különféle nukleázok hatására N2a sejtekben. Hat nukleázt teszteltünk, mindegyiket öt különböző targeten, a GFxFP esszé alkalmazásával. Az oszlopok az egyes nukleázok esetében az öt különböző target hasítási hatékonyságára kapott átlagértékeket mutatják. A GFP pozitív sejteket a transzfekció után két nappal mértük. Az összes mintát mCherry expressziós vektorral együtt transzfektáltuk, és az eredményeket az mCherry pozitív populáción belül elemeztük. A negatív kontrollok GFP fluoreszcenciáját inaktív SpCas9-et expresszáló vektor alkalmazásával mértük, és a kapott értékeket kivontuk minden egyes minta értékéből. Minden targettel három párhuzamos transzfektálást hajtottunk végre. Az átlagos HR-indukáló hatékonyságot 15 minta átlagából számoltuk nukleázonként. A hibasávok a százalékos értékek átlagainak szórását mutatják. SpCas9: zöld, LbCas12a: világos zöld, AsCas12a: sárga, SaCas9: narancs, StCas9: piros, NmCas9: skarlát ${ }^{35}$.

\subsubsection{Az As- és LbCas12a nukleázok által végzett genomi DNS-hasítás hatékony HR} javítást képes indukálni

Következő lépésként leteszteltük, hogy az As- és LbCas12a nukleázok képesek-e HR javítást indukálni a genomban. Ehhez leteszteltünk négy targetet a genomi környezetükben egy donor molekula segítségével. A donor molekula egy promóter nélküli GFP nyitott leolvasási keretet (ORF) tartalmaz, amelyet 1000 bp hosszúságú, a PRNP génnel homológ karok fognak közre. A célzott integráció után a PRNP ORF helyébe a GFP ORF kerül, ahol a GFP expresszióját a PRNP gén promótere vezérli. A PRNP-t célzó crRNS-t tartalmazó As- és LbCas12a nukleázokat kódoló plazmidokat kotranszfektáltuk a donor plazmiddal, és megfigyeltük a GFPt expresszáló sejtek számát. Meglepő módon a promóter nélküli donor plazmid az inaktív dSpCas9-et expresszáló plazmiddal kotranszfektálva is eredményezett némi GFP fluoreszcenciát, amikor a transzfekció után két nappal mértük a fluoreszcens jelet. 
Ezt a tranziens fluoreszcens szignált a további kísérletekben arra használtuk, hogy összehasonlítsuk a különböző minták transzfekciós hatékonyságát. Ez a tranziens GFP jel körülbelül 9 napon belül lecsengett, ami már lehetővé tette az integrált GFP kazettákból származó GFP jel mérését. A 15. ábrán látható eredmény azt mutatja, hogy mindkét nukleáz képes elősegíteni a HR javítást, ezáltal a donor kazetta homológ integrációját az N2a sejtekbe. A négy vizsgált PRNP-célpont közül az LbCas12a hármat, míg az AsCas12a két targetet hasított, amelyek az inaktív nukleázzal kotranszfektált negatív kontroll szintjénél nagyobb arányban eredményeztek fluoreszcens sejteket. Hasonlóan alacsony fluoreszcenciaszintet találtunk egy olyan kontrollban is, ahol a Cas12a nukleázokat megfelelő homológ kar nélküli donor plazmiddal aktív nukleázzal kotranszfektáltuk (nincs ábrázolva), ami azt mutatja, hogy a Cas12a aktivitása nem eredményez szignifikáns fluoreszcenciát a nem HR javítás által közvetített donor véletlenszerü integrációjával. Ez valószínűleg annak köszönhető, hogy a GFP kazetta előtt nem található promóter a plazmidban, így az integrációja nem eredményez expressziót, hacsak nem pont egy promóter után integrálódik a genomba.

A fejezet összes eredménye az Irodalomjegyzékben 35. számmal hivatkozott publikációnkból származik.

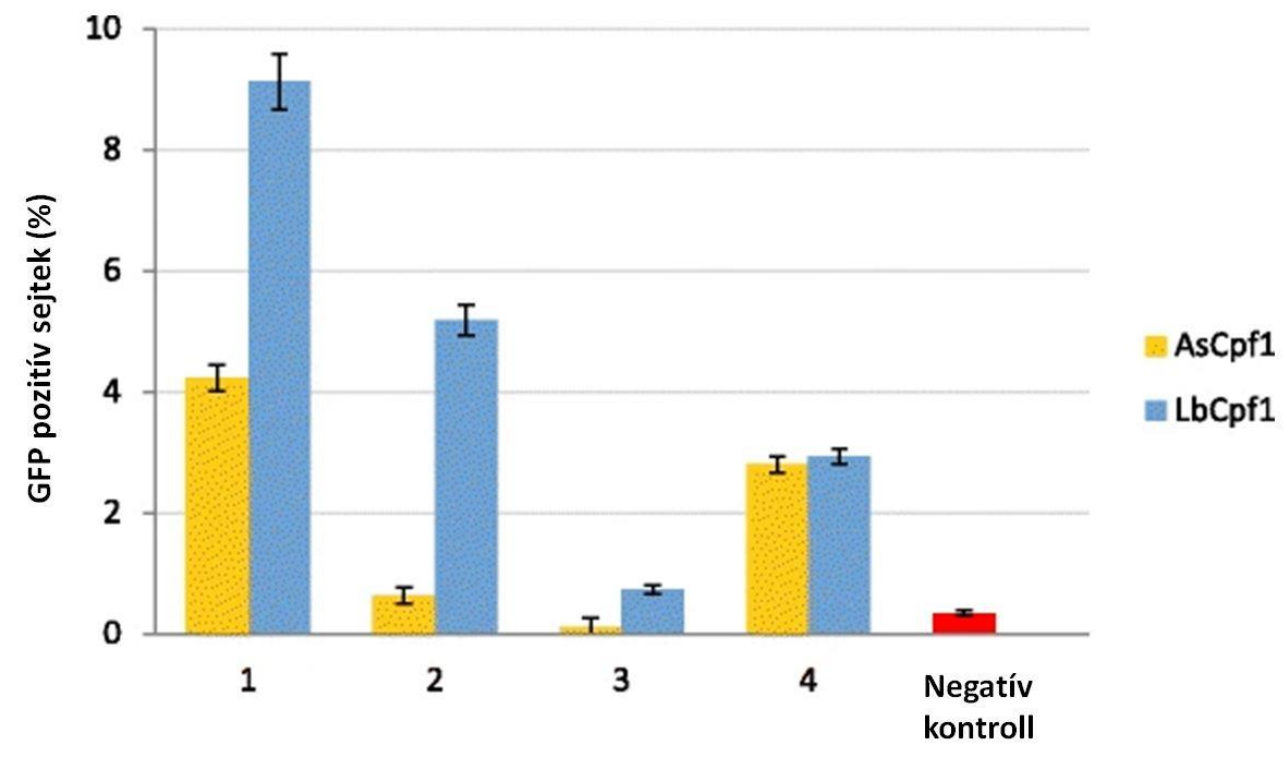

\section{5. Ábra. Az As- és LbCas12a-indukált HR javítás szintje genomi targeteken}

Az ábrán a GFP pozitív sejtek százalékos aránya látható egy promóter nélküli donor GFP kazetta HR javitás által közvetített genomi integrációja után. Mind az As-, mind az LbCas12a nukleázok (narancssárga és kék) hatékonyságát négy egér PRNP genomi célszekvencián teszteltük. A nukleázvektort és a homológ rekombinációs donor plazmidot kotranszfektáltuk N2a sejtekbe. Negatív kontrollként a sejteket a donor molekulával és egy inaktív SpCas9 expressziós plazmiddal kotranszfektáltuk. A transzfekció utáni hetedik napon lemértük a GFP pozitív sejteket. Minden mintához három párhuzamos transzfektálást hajtottunk végre. A hibasávok a százalékos értékek átlagainak szórását mutatják ${ }^{35}$. 


\subsection{Megnövelt specificitású SpCas9 nukleázok vizsgálata}

A fejezet összes eredménye, valamint ezekkel kapcsolatos további eredmények az Irodalomjegyzékben a 48. számmal hivatkozott publikációnkban található.

Munkám ezen részében azt kívántuk megvizsgálni, hogy a megnövelt specificitású eSpCas9 és SpCas9-HF1 nukleázok aktivitását hogyan befolyásolja a módosított gRNS-ek alkalmazása. Ezen nukleázok széles körü alkalmazhatósága attól függ, hogy képesek-e a módosított gRNSekkel hatékonyan müködni. Olyan targetek esetében, ahol a spacer 20. pozíciójának megfelelő nukleotid nem G, különféle gyakorlatok vannak a gRNS spacer 5'-végének módosítására (lásd 2.4. és 2.5. fejezet). A disszertációmban bemutatott munka során arra irányuló vizsgálatokat végeztünk, amelyekben a spacerek 5' végének rövidítését, 5' végükön G-t nem tartalmazó gRNS-ek, vagy 5' végükön a 20. pozícióban egy nem komplementer G nukleotidot tartalmazó gRNS-ek hatását vizsgáltuk az SpCas9 variációk aktivitására. Utóbbi kettőt azért teszteltük, mert ezeknek a módszereknek a segítségével nemcsak G kezdetü targetekkel lennének használhatók a vizsgált megnövelt specificitású nukleázok. Az 5' végükön rövidített gRNSeket azért teszteltük le, mert több cikk szerint ha az U6 promótert nem követi G, 5' végükön rövidebb RNS-ek keletkezhetnek ${ }^{75}$. Ahhoz, hogy a megnövelt specificitású SpCas9 nukleáz variánsok aktivitását megfigyeljük, számos targeten direkt összehasonlításokat végeztünk el EGFP hasítási teszttel. Ennek során N2a.EGFP sejteket használtunk. Ez egy olyan, a csoportunkban létrehozott sejtvonal, amely az EGFP kazetta egyetlen kópiájú integrált példányát tartalmazza Neuro-2a egér neuroblasztoma sejtekben, ami a PRNP promóterről expresszálódik. A nukleázokkal különböző EGFP szekvencián belüli targeteket céloztunk és az aktivitásuk szintjét az EGFP szignál csökkenésével mértük. A kísérletekben az N2a.EGFP sejteket kétféle plazmiddal kotranszfektáltuk: a különböző SpCas9 variációkat kódoló expressziós plazmiddal, valamint a különféle EGFP targeteknek megfelelő spacereket magukban foglaló gRNS-t és mCherry-t kódoló plazmiddal, és a sejteket áramlási citometriával értékeltük. Az mCherry fluoreszcenciája a transzfekciós hatékonyság, az EGFP fluoreszcencia csökkenése pedig a nukleázok hasítási hatékonyságának meghatározására szolgált. 


\subsubsection{5’ végükön nem G-t, vagy a 20. pozícióban nem komplementer G-t tartalmazó gRNS-ek alkalmazása}

Azoknál a targeteknél, amelyeknél a spacer 20. pozíciójának megfelelő nukleotid nem G, bevett gyakorlat a target szekvencia változtatás nélküli felhasználása, vagy a 20. pozíció G nukleotidra cserélése, amely így a targethez nem kitapadó 20. G-t eredményez a gRNS-ben. 18 gRNS-t teszteltünk le, melyeknek a fele egy 5' kitapadó nem-G nukleotidot tartalmaz, a másik felében pedig ugyanaz a spacer, de az 5' első nukleotid egy nem kitapadó G. Azt találtuk, hogy a WTSpCas9 valamivel jobban müködik egy nem kitapadó kezdő G-vel, mint a nem G kezdetü spacerekkel (16. ábra a). Bár az eSpCas9 viszonylag jól müködik a nem G kezdetű spacerekkel, és a WTSpCas9 aktivitásához mérten csak mintegy 20\%-os csökkenés figyelhető meg a targetek többségénél (6/9), a 20. pozícióban a nem kitapadó G-re történő csere jelentősen csökkenti az aktivitását. Az SpCas9-HF1 lényegesen csökkent aktivitást mutat mindkét változatú módosított gRNS-el a WTSpCas9-hez képest.

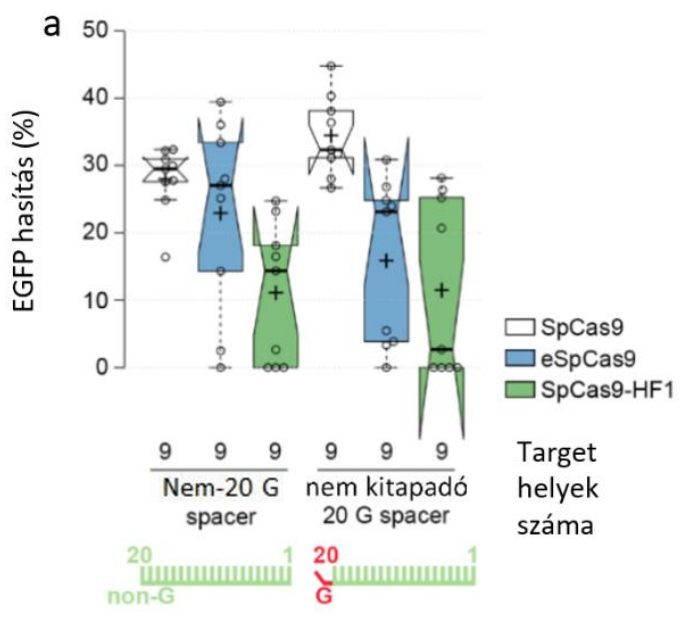

b

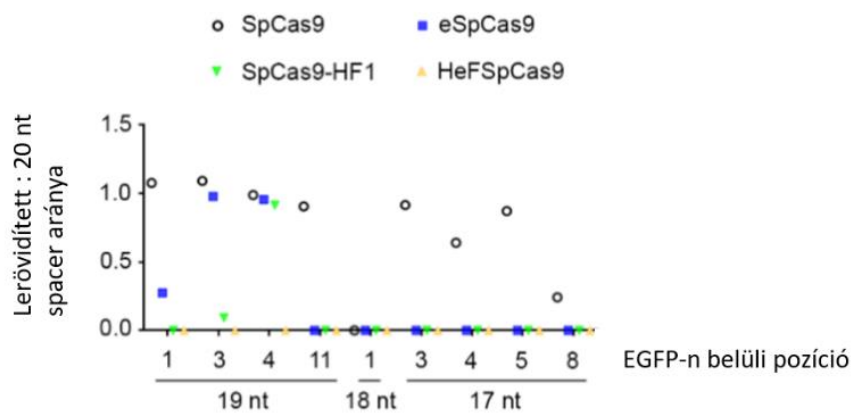

16. Ábra. A gRNS különféle módosításainak hatása az SpCas9 nukleáz variánsok EGFP hasításának aktivitására

Az ábrán a spacer 5' végének módosításának hatása látható a nukleázok aktivitásra. a) 20 nt hosszú 5' végen kitapadó, de nem G-t tartalmazó, és 20 nt hosszú 5' végen nem kitapadó G-t tartalmazó spacerek hatása a nukleáz aktivitásra. b, A gRNS-ek 5' végének rövidítésének hatása a vad típusú SpCas9, eSpCas9, SpCas9-HF1 és HeFSpCas9 aktivitására. Az ábrán a rövidített gRNS-ekkel alkalmazott SpCas9-ek aktivitásának aránya van ábrázolva a normál hosszúságú gRNS-ekkel alkalmazott SpCas9-ek aktivitásával. Tukey-típusú box-plot a BoxPlotR által: a középvonalak a mediánokat mutatják; a boxok határai a 25. és 75. percentilist jelzik; a szimpla vízszintes vonal az interkvartilis tartomány 1,5-szereséig terjed ki a 25. és 75 . percentilistől; a bevágások a boxokon a mediánok 95\% -os konfidencia intervallumát jelzik; a keresztek a minta átlagát képviselik; az adatpontok körökként vannak ábrázolva. Az egyes nukleázok mintapontjának számai megfelelnek az alkalmazott targetek számának. Az adott kísérletekhez használt spacerek típusai zöld színü fésüként vannak ábrázolva, és a 20. G nukleotidok (a PAM-szekvenciától számozva) piros színü, hajlított fésűfogakként vannak jelölve, ha nem tapadnak ki; a zöldek a kitapadó nukleotidokat képviselik ${ }^{48}$. 


\subsubsection{5’ végükön rövidebb gRNS-ek alkalmazása}

Annak vizsgálatára, hogy az SpCas9 variánsok miként tolerálják a rövidebb spacereket, 5 EGFP targetet választottunk ki, amelyböl 9 db rövidített, 17, 18 vagy 19 nukleotid spacer hosszúságú gRNS-eket kódoló plazmidokat hoztunk létre, amelyek mindegyike kitapadó G-vel kezdődik. Ezekkel a gRNS-ekkel kotranszfektált SpCas9-ek EGFP hasítási aktivitását hasonlítottuk össze normál hosszúságú gRNS-ekkel kotranszfektált SpCas9-ek aktivitásával (16. ábra b). A kilenc csonkolt hosszúságú spacert tartalmazó gRNS-ek közül 8-al sikeresen hasította az EGFP-t a WTSpCas9. Ezzel szemben az eSpCas9 és az SpCas9-HF1 csak három, illetve egy targetet hasított, és ezek mind csak egy nukleotiddal rövidített, 19 nt hosszúságú spacerek voltak. Az általunk létrehozott, mind az eCas9, mind az SpCas9-HF1 mutációinak kombinációit tartalmazó HEFCas9 variáns egyik rövidített spacert tartalmazó gRNS-el sem müködött.

Ezek a kísérletek azt mutatják, hogy a megnövelt specificitású Cas9 variánsok aktivitását csökkentik ezek a gRNS módosítások. A bemutatott változtatások az összes általunk vizsgált módosított Cas9 nukleáz aktivitását csökkentették, különböző mértékben. Az eSpCas9 alacsonyabb érzékenységet mutatott a módosításokra az SpCas9-HF1-hez képest.

A fejezet összes eredménye az Irodalomjegyzékben 48. számmal hivatkozott publikációnkból származik. 


\subsection{A CRISPR gRNS-ek expressziójára gyakran alkalmazott promóterek}

A fejezetben szereplő eredményekből készülő kézirat jelenleg beküldés elött áll.

\subsubsection{A randomizált bázisokkal módosított gRNS}

A promóterek vizsgálatához olyan plazmid és ezekről létrehozott cDNS könyvtárakat készítettünk el, amelyekben a promóterektől downstream elhelyezkedő első 4 nukleotid randomizált volt. A transzkriptumok 3' irányban egy módosított SpCas9 gRNS-el folytatódtak. Az SpCas9 gRNS-t azért választottuk a promóterek vizsgálatához az RNS-t kódoló szekvenciaként, mert erős másodlagos szerkezete van a spacertől 3' irányban elhelyezkedő szakaszán. Ebből fakadóan azt képzeltük, hogy jobban tolerálja a randomizált szakaszokon belüli szekvencia különbségeket és a 12 bázisos bárkódot egy olyan helyre illesztettük, amiről azt felételeztük, hogy kevésbé változtatja meg a szerkezetét.

A 17. ábrán látható, hogy milyen másodlagos szerkezet jellemző az SpCas9 gRNS-ére és hogy hova illesztettük a bárkódot. A bárkód szolgált arra, hogy a különböző hosszúságú és mennyiségü RNS-ek kiindulási mennyiségét, valamint a DNS templátjaik szekvenciáját azonosíthassuk. A bárkódok nemcsak abban nyújtottak segítséget, hogy ez alapján beazonosíthassuk melyik RNS szekvencia melyik templátról keletkezett. Azzal, hogy egy szekvencianégyeshez sok teljesen más szekvenciájú 12 bázisos bárkód tartozott, az RNS mennyiségekre ható külső tényezők hatását csökkentettük, mint pl. RNS szerkezetbeli különbségekből adódó eltérő RNS degradációt.

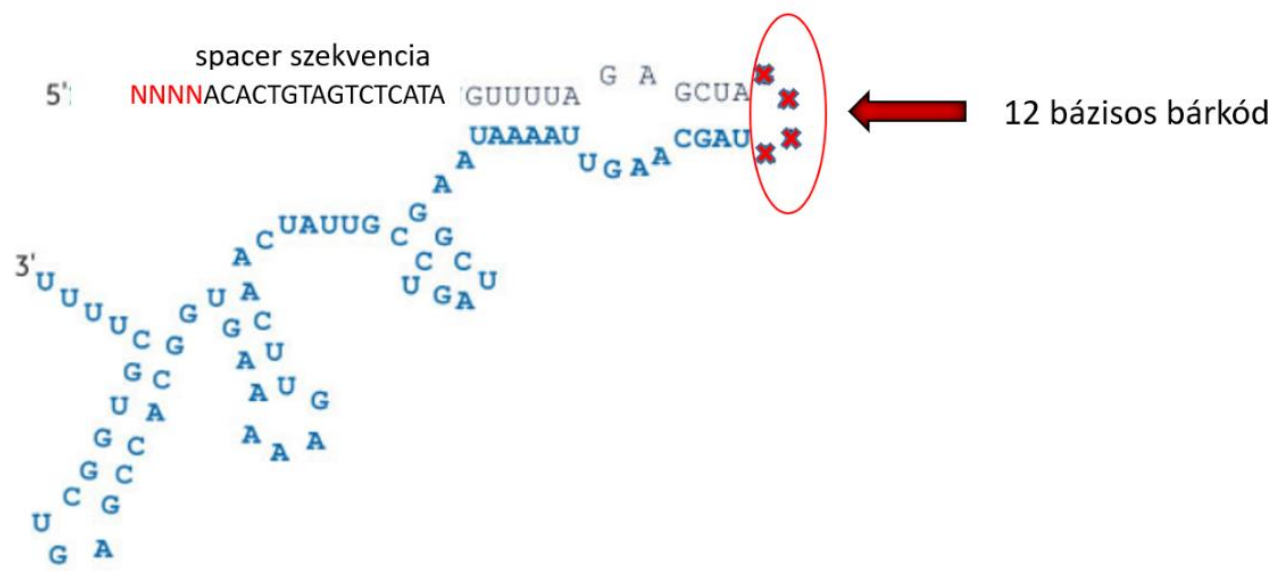

\section{7. Ábra. Randomizált bázisokkal módosított SpCas9 gRNS}

Az ábra az SpCas9 gRNS másodlagos szerkezetét ábrázolja a randomizált bázisokkal. X-el azok a nukleotidok vannak jelölve, amelyeknek a helyére illesztettük a bárkódot.

Ábra forrása:

https://horizondiscovery.com/en/applications/crispr-cas9/synthetic-sgrna-for-crispr-cas9 experiments alapján 


\subsection{2. cDNS+adapter ligálási módszer}

A cDNS-re való adapter ligálásához egyedi módszert alkalmaztunk több okból kifolyólag. A meglévő módszerek olyan RNS-ek szekvenálásához, mint pl. a Cas9 guide RNS, melynek 3' végének szekvenciája ismert, általában felesleges lépéseket tartalmaznak, és emellett túlságosan idő és anyagigényesek. Módszerünk során a tisztított RNS-eket rögtön cDNS-ekké írjuk át, majd a cDNS-t ligáljuk egy ismert szekvenciájú adapterrel, végül a ligátumot PCR-el amplifikáljuk NGS-hez.

Az adapter ligáláshoz a T4 DNS ligázt választottuk, abból az okból kifolyólag, hogy nincs nukleotid preferenciája ${ }^{76,77}$. Bár alapvetően ezt a ligázt duplaszálú DNS-ek tompa, vagy ragadós végeinek összeligálásához használják, egyszálú DNS-ek ligálására is képes egy splint oligó segítségével ${ }^{76}$. Ezek ismeretében azt a módszert választottuk, melynek sematikus ábrázolása a 18. ábrán látható. A cDNS-re ligálandó adapterhez hozzáhibridizálunk egy részben komplementer oligót, aminek van egy 4 randomizált nukleotidot tartalmazó túlnyúló vége, és a cDNS első 4 nukleotidjához annelálódva, a T4 DNS ligáz képes összeligálni az adaptert a cDNS-el. A ligáláshoz használt oligonukleotidokat úgy terveztük meg, hogy ne keletkezhessenek ligálási melléktermékek. Az adapter komplementer oligó 3', és az adapter 3' végén is egy plusz foszfát csoport van, amely gátolja a ligáz müködését. Csak az adapter 5' végén van foszfát csoport, amely a T4 ligáz müködéséhez szükséges (18. ábra). Mivel a T4 DNS ligáz 5'P véget ligál 3'OH véghez, így csak az adapter 5'P vége tud a cDNS-el ligálódni. Amiatt, hogy a T4 DNS ligáz egyszálú DNS-ek ligálását kisebb hatékonysággal végzi, mint a duplaszálúakét, a módszer eredményes használatához be kellett állítani az optimális kondíciókat. Ezek közé tartozott a ligálás időtartama, hőmérséklete, oligó koncentráció és PEG koncentráció (melynek használata elősegíti a ligálás hatékonyságát). Vizsgálataink alapján optimális körülményeknek a következőket találtuk: $37^{\circ} \mathrm{C}, 1$ h, 20\% PEG. 


\section{[5']CGTCAGATGTGTATAAGAGACAGNNNN [3'P] [3’P]AGCAGCCGTGCAGT CTACACATATTCTCTGTC[5'P]}

b,
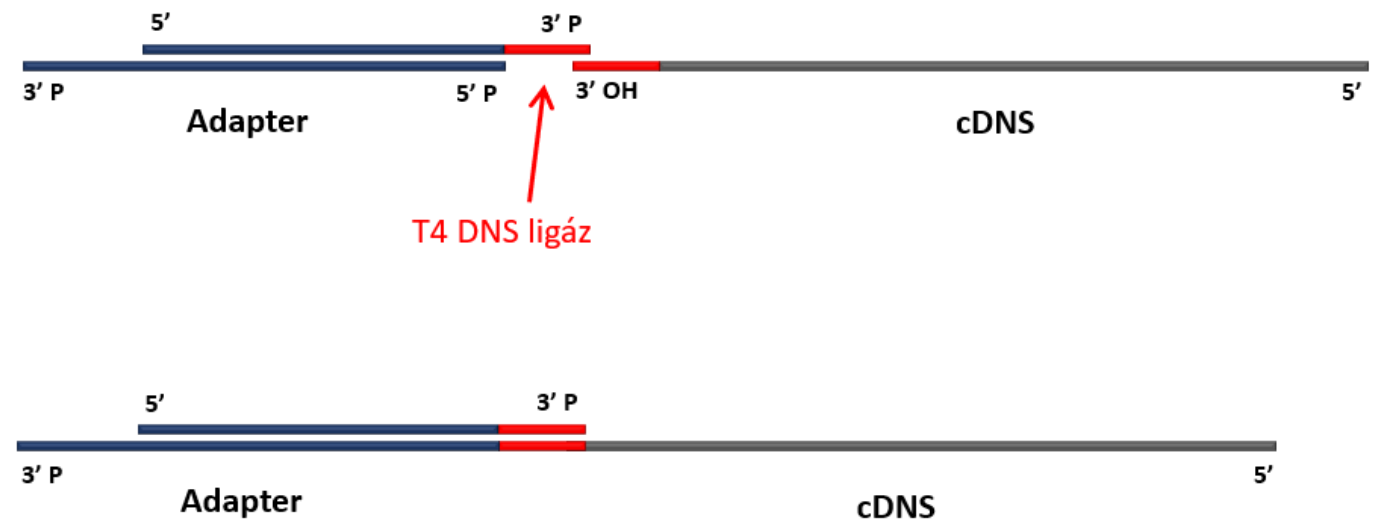

\section{8. Ábra. cDNS+adapter ligálás}

Az ábrán a cDNS-re ligált adapter és adapter komplementer oligók szekvenciája (a), valamint a cDNS+adapter ligálás sematikus ábrázolása (b) látható. a, A két oligó szekvenciája, végmódosításaikkal. b, Pirossal a 4 nt hosszú randomizált nukleotidokat tartalmazó szakasz, szürkével a cDNS, kékkel az adapter és komplementere van ábrázolva.

\subsubsection{Emlős promóterek összehasonlítása}

Azt kívántuk összehasonlítani, hogy HEK-293 sejtekben a humán U6, humán 7sk, U6T7 hibrid promóterekről mennyi RNS termelődik egymáshoz képest. Ehhez 3 plazmidkönyvtár keveréket csináltunk, ahol keverékenként más spacer szekvenciát tartalmazó gRNS-ek expresszálódnak az egyes promóterekről. A plazmidkeverékeket egyszer csináltuk meg, ezekből 3-3 párhuzamost transzfektáltunk a sejtekbe. Az NGS elemzéséből kapott plazmidkeverékek readszámaira normalizáltuk az RNS-ek readszámait, megfelelő promóter-spacer párosonként. Ezután megnéztük, hogy melyik RNS könyvtár mekkora százalékot tett ki az adott keverék összes RNS-éből. Az eredmények alapján, amelyek a 19. ábrán láthatók, nincs szignifikáns eltérés a 3 promóter között, hasonló mennyiségű RNS termelődik mindegyik promóterről HEK293 sejtekben. 


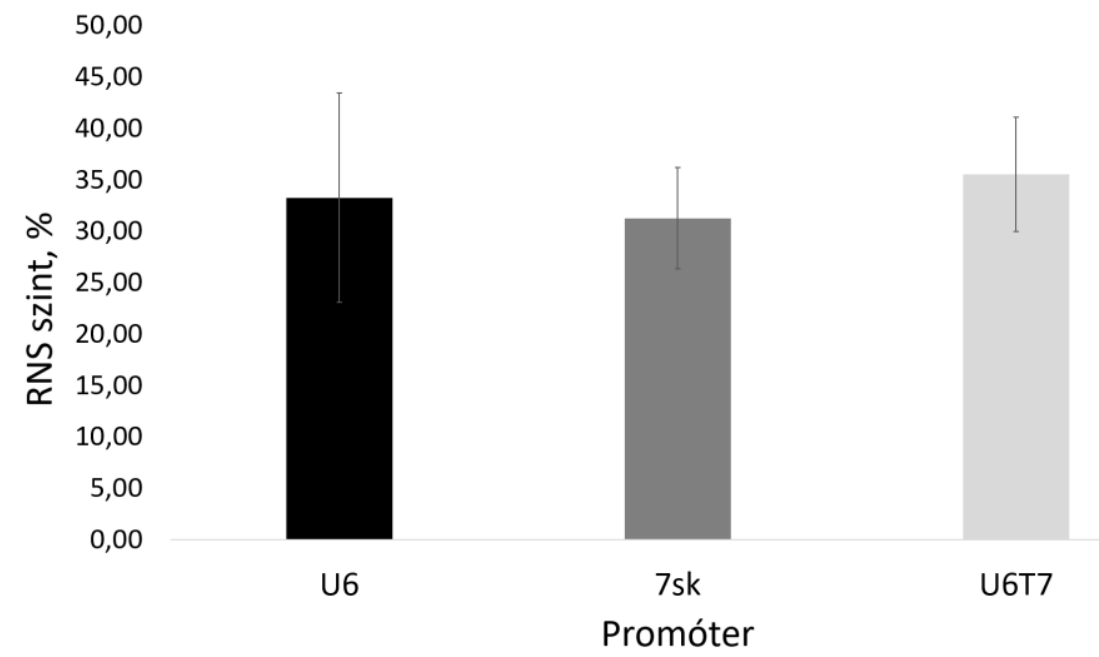

19. Ábra. Emlős promóterek expressziójának összehasonlítása HEK-293 sejtekben

Az ábra megmutatja, hogy az U6, 7sk, U6T7 promóter-gRNS kazettákat tartalmazó plazmidokat kotranszfektálva emlős sejtekbe az egyes promóterekről az összes RNS hány \%-a keletkezett. Feketével az U6, sötétszürkével a 7sk, világosszürkével az U6T7 promóterről keletkezett RNS-ek mennyisége látszik. A hibasávok a százalékos értékek átlagainak szórását mutatják.

\subsubsection{A promótertől downstream elhelyezkedő +1-től +4-ig terjedő pozíciók vizsgálata}

\section{az RNS expresszióra és a transzkripció iniciációs pozícióra}

Annak tanulmányozására, hogy a CRISPR gRNS expresszióra gyakran alkalmazott promóterekről termelődő RNS-ek mennyiségét és hosszát megfigyelhessük, 5 promótert, a humán U6, humán 7sk, az U6T7 hibrid promótert, a T7 és a bakteriális J23119 promótert vizsgáltunk meg. Az NGS adatok feldolgozása alapján az összes plazmid könyvtár promótert követő 4 bázispáros szekvencia variációinak mindegyike (256 variáció) átlagosan minimum 5000 darab számú readdel képviseltette magát (20. ábra). 


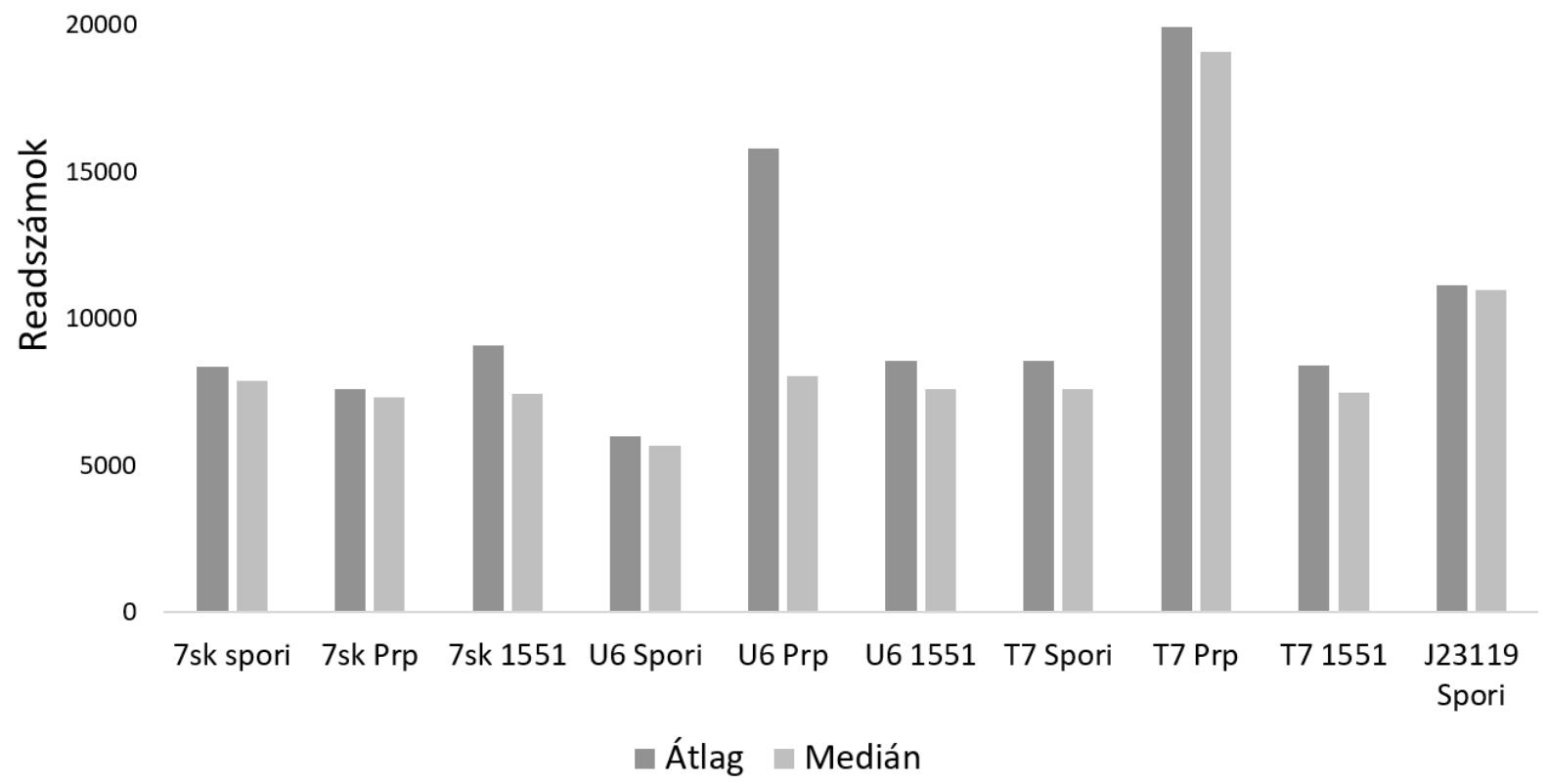

20. Ábra. A promótert követő 4 bázispáros szekvencia variációk NGS readszámainak átlagai és mediánjai plazmidkönyvtáranként

Az ábrán a promótert követő 4 bázispáros szekvencia variációk readszámainak átlagai és mediánjai vannak feltüntetve plazmidkönyvtáranként. A sötétszürke oszlopok a readszámok átlagait, míg a világosszürkék a mediánokat mutatják.

A plazmidkönyvtárakból létrehozott cDNS könyvtárak readszámainak mennyisége és a readek hossza, amelyekből az RNS-ek hosszát számoltuk ki, a promótert követő 4 bázisos szekvenciától és a promótertől függően változott. Az emlős promóterek összehasonlítását kivéve az összes további eredmény az NGS adatokból úgy került kiszámításra, hogy a plazmid könyvtárak bárkódjai alapján azonosítottuk és a templátra normalizáltuk az adott templátokról keletkezett RNS-ek szekvenciáját, 5' végének hosszát és RNS mennyiségét. Ezt követően a különböző bárkódokról keletkezett, eltérő hosszúságú RNS-ek mennyiségét kezdő szekvenciánként és azonos hosszúságonként összeadtuk, cDNS könyvtáranként. Promóterenként 3-féle spacert tartalmazó SpCas9 gRNS 3-3 párhuzamos cDNS könyvtárait vizsgáltuk, kivéve az U6 promótert, ahol a Spori spacerrel 2 párhuzamos cDNS könyvtár volt, és a J23119 promótert, ahol csak a Spori spacer 3 párhuzamos cDNS könyvtárát vettük figyelembe, abból az okból kifolyólag, hogy a többi esetben nem volt minden kezdő szekvenciáról megfelelő számú read. 


\subsubsection{Az U6 promóter}

Az NGS eredményeink alapján először megvizsgáltuk az első nukleotid szerepét a transzkripciós iniciációs pozíciókra, melynek eredménye a 21. ábrán látható. Ha a +1-es pozícióban A volt, akkor az összes RNS átlag 87\%-a keletkezett a +1 pozícióról, +1G-vel ez $89 \%$ volt. A purinokhoz képest rendkívül kis arányban indul el pontosan az átírás, ha a +1 pirimidin: +1C-vel 30\%, +1T-vel 16\% volt a +1-ről átíródott RNS-ek aránya.

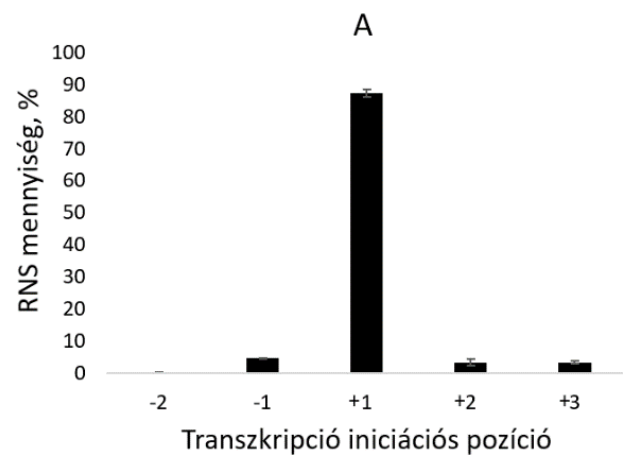

G

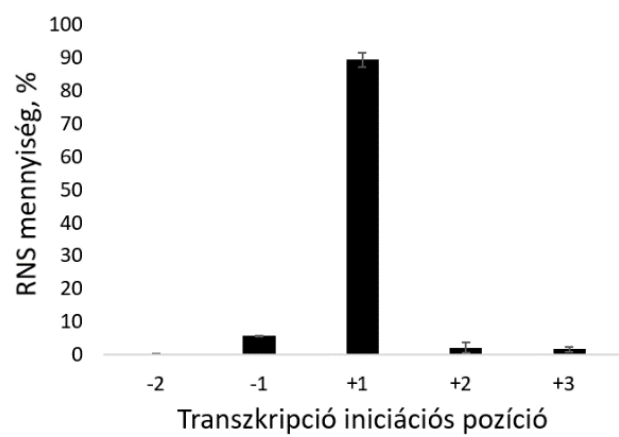

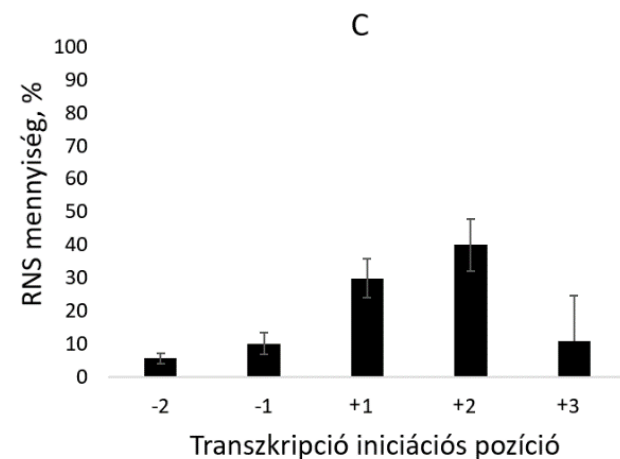

T

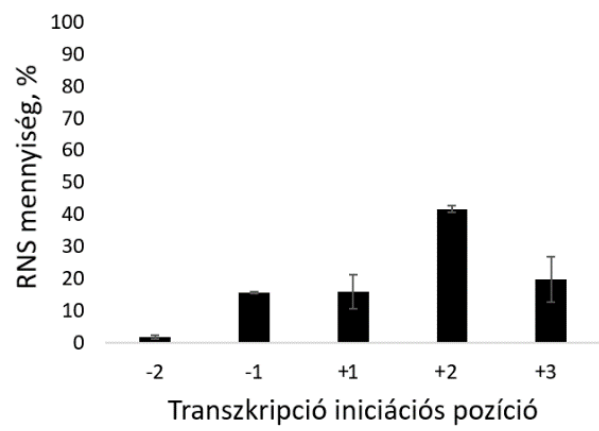

21. Ábra. Az U6 promótertől downstream elhelyezkedő első nukleotid hatása a különböző transzkripció iniciációs pozíciókra

Az ábrán látható, hogy az U6 promótertől downstream elhelyezkedő első nukleotid miképp befolyásolja, hogy melyik pozícióról milyen arányban indul el az átírás. Egy oszlop megmutatja, hogy az összes vizsgált pozícióról termelődött RNS-ek összegének átlagban hány \%-a íródott át adott pozícióról. A hibasávok a százalékos értékek átlagainak szórását mutatják. $\mathrm{N}=8$, amely a 8 cDNS könyvtárnak felel meg.

Ezután megvizsgáltuk a további pozíciókban lévő nukleotidok szerepét is a különböző transzkripciós kezdő pozíciókra (22. ábra). Azt találtuk, ha az első pozícióban purin van, a további pozíciók már nem befolyásolják olyan nagymértékben a kezdő pozíciót, mint a kezdő pirimidineknél, hanem az RNS-ek nagyrészt a +1-ről íródnak át. Ha a +1-ben pirimidin van, és a +2-ben purin, akkor nagyobb arányban indul el a +2-ről a transzkripció, mint a +1-ről, ilyenkor kimarad a +1 , és az átírás az első purint tartalmazó nukleotidról, a +2-es pozícióról indul el. Ha a +1 és a +2 is pirimidin, de a +3 purin, szintén megfigyelhető, hogy megnő azoknak az RNS-eknek az aránya, ahol kimarad a +1 és a +2 is, és az átírás az első purint tartalmazó nukleotiddal, a +3-as pozícióról indul el. 


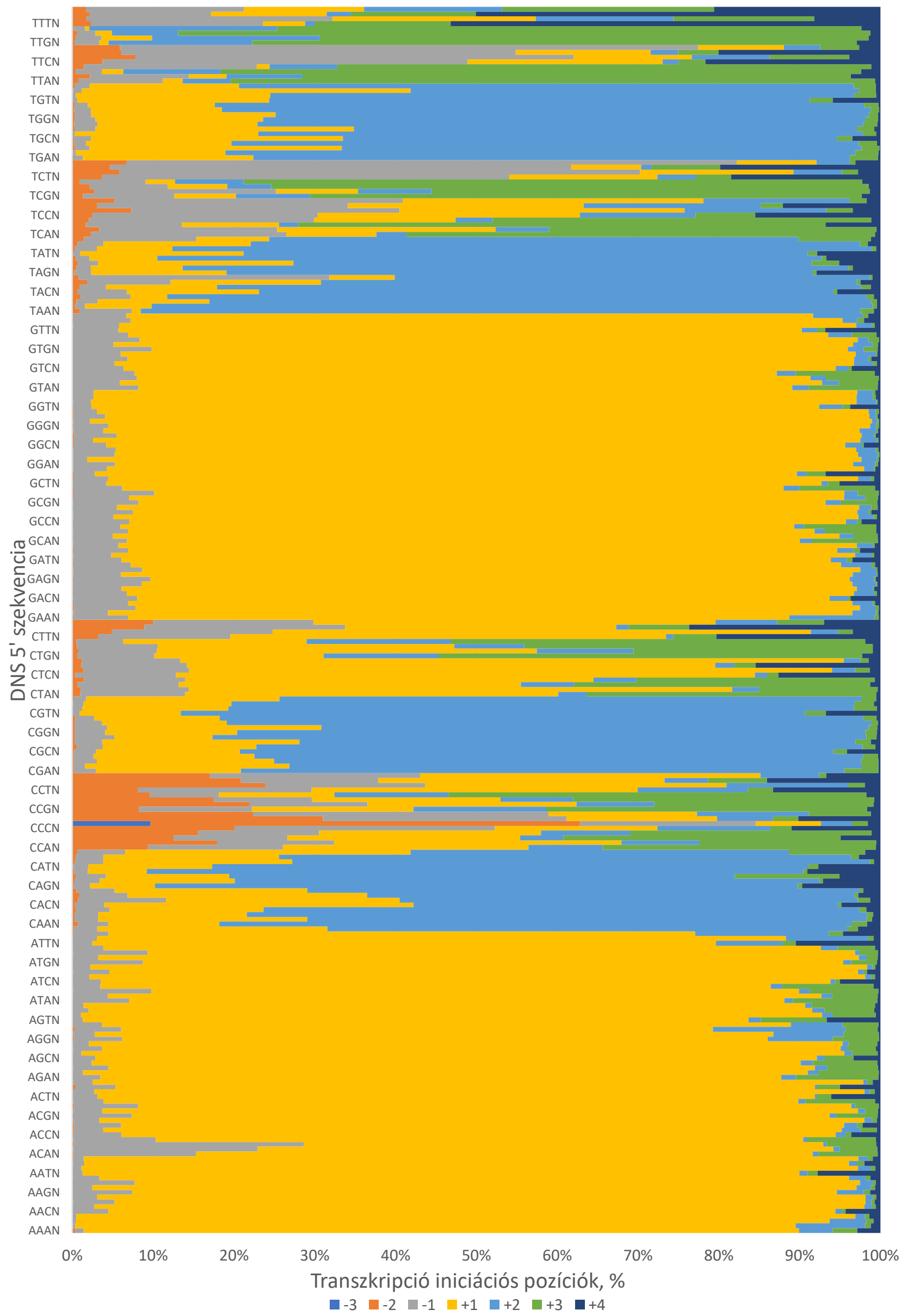


22. Ábra. Az U6 promótertől downstream elhelyezkedő szekvenciák hatása a különböző transzkripció iniciációs pozíciókra

Az ábrán látható, hogy az U6 promótertől downstream elhelyezkedő szekvenciák miképp befolyásolják, hogy melyik pozícióról milyen arányban indul el az átírás. Egy oszlop egy színe megmutatja, hogy az összes vizsgált pozícióról termelődött RNS-ek összegének átlagban hány \%-a íródott át adott pozícióról, és egy oszlop egy darab kezdő szekvenciát jelöl. A közepesen világoskék szín a -3, a narancssárga szín a -2, a szürke szín a -1, a citromsárga szín a +1 , a világoskék szín a +2 , a zöld szín a +3 és a sötétkék szín a +4 pozíciókat jelöli az U6 promótertől downstream. $\mathrm{N}=8$, amely a 8 cDNS könyvtárnak felel meg.

A+1-es pozícióban A-val, vagy G-vel szinte csak jó hosszúságú RNS-ek keletkeztek, legnagyobb arányban a +1-ben kezdődik az átírás (23. ábra). Van néhány szekvencia +1A-val, amelyiknél a +1-es pozícióról induló transzkripció aránya kisebb, de $+1 \mathrm{~A}$ és $+1 \mathrm{G}$ között nincs jelentős eltérés abban, hogy milyen arányban indul el a transzkripció iniciációja a +1-ről. Eredményeink azt mutatják, hogy ha az U6 promóter után az első nukleotid purin, az átírás nagyrészt a +1-ről indul el, és a kezdő pozíciót a további pozíciók csak kis mértékben befolyásolják, míg ha a +1 pirimidin, az átírás nemcsak +1 -ről történik. Azt, hogy pirimidin esetében melyik pozícióról milyen arányban történik a transzkripció iniciációja, nagymértékben befolyásolják a promótertől downstream elhelyezkedő további nukleotidok is.
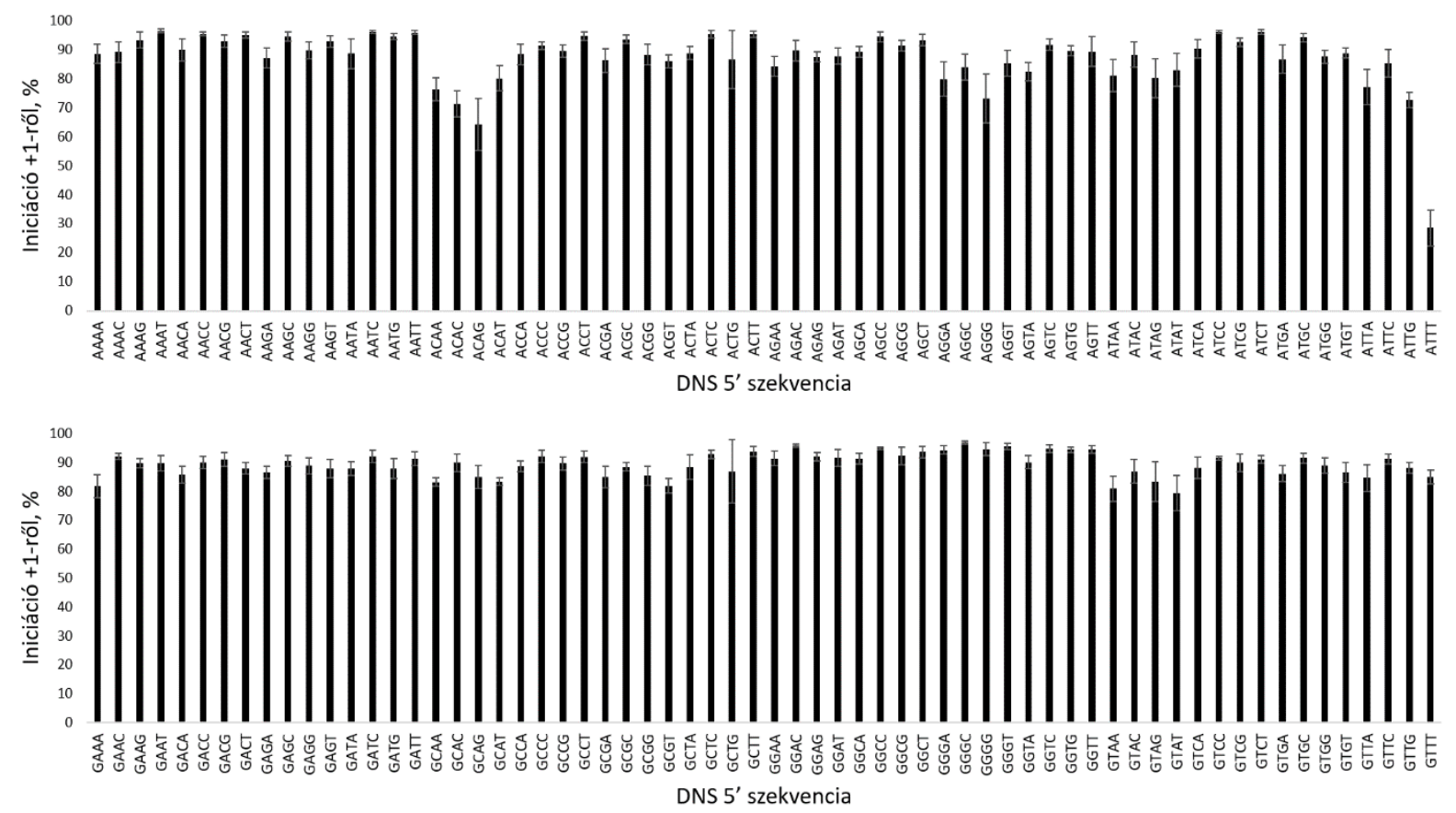

23. Ábra. Az U6 promótertől downstream lévő szekvenciák hatása a +1-ről induló transzkripcióra, ha a +1 A, vagy G

Az ábrán az U6 promóter után elhelyezkedő különböző szekvenciák szerepe látható a +1 -es pozícióról történő átírásra. Az oszlopok megmutatják, hogy átlagban hány \%-ban indult el +1-ről az átírás adott templát DNS szekvencia esetén. A hibasávok a százalékos értékek átlagainak szórását mutatják. $\mathrm{N}=8$, amely a 8 cDNS könyvtárnak felel meg. 
A következő lépésekben azt néztük meg, hogy az U6 promótertől downstream elhelyezkedő nukleotidok hogyan hatnak a transzkriptumok mennyiségére. A +1-es pozíció szerepét vizsgálva az átíródott RNS-ek mennyiségére azt találtuk, hogy ha a +1-ben purin van, több RNS termelődik, mintha pirimidin (24. ábra). A purinokról és a pirimidinekről keletkezett transzkriptumok mennyisége egymástól szignifikánsan eltér, a 2 purint egymással, illetve a 2 pirimidint egymással összehasonlítva azonban nincs szignifikáns különbség.

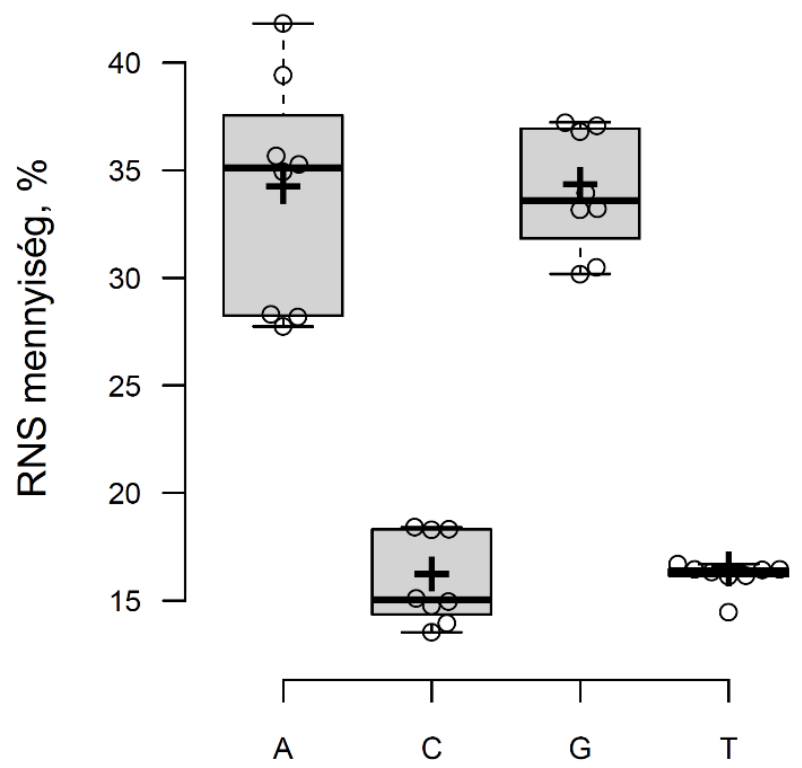

DNS 5' szekvencia

\section{4. Ábra. A +1-es pozícióban lévő nukleotid hatása az RNS expresszióra}

Az ábrán a +1-es pozícióban lévő nukleotid hatása látható az U6 promóterről termelődött RNS-ek mennyiségére. Az ábra az összes transzkripciós iniciációs pozíció transzkriptumainak mennyiségeit mutatja. 1 adatpont megadja, hogy adott nukleotiddal az összes RNS hány \%-a keletkezett az adott cDNS könyvtáron belül. A boxokon belüli vastag vízszintes vonalak a mediánokat mutatják; a boxok határolják az R programmal meghatározott 25 . és 75 . percentilist; a szimpla vízszintes vonalak az interkvartilis tartomány 1,5-szereséig terjednek ki a 25 . és 75 . percentilistől; a keresztek a minták átlagát mutatják; az adatpontok körökként vannak ábrázolva. $\mathrm{N}=8$, amely a 8 cDNS könyvtárnak felel meg. A p értékek a Függelékben a 109. oldalon találhatók meg.

A promótert követő első 2 pozíciót vizsgálva azt kaptuk, hogy a legtöbb RNS AG, GG kezdettel keletkezik (25. ábra). AG és GG szignifikánsan a legjobbak a 16 variáció közül és egymástól nem különböznek. CC, CT, TC, TT pedig szignifikánsan mindennél kevesebb RNS-t eredményeznek (25. ábra). Összehasonlítottuk egymással a +1 pozícióban A-t tartalmazó templátokról termelődött RNS-ek mennyiségét. Az első két pozíciót vizsgálva az látszik, hogy szignifikáns különbség csak az AG és az összes többi között van, AA, AC, AT között nincs, és AG kezdettel termelődött a legtöbb RNS. Az első két pozíciót vizsgálva a GA-GC párost leszámítva minden variáció szignifikáns különbségeket okozott $+1 \mathrm{G}$-vel az RNS mennyiségekben, és a 2. pozícióban a G után is a G bizonyult a legjobbnak (25. ábra). A 25. ábrán látható, hogy az első két pozíció dinukleotidjai különösen meghatározóak az RNS 
expresszióra nézve: AG és a GG szignifikánsan nagyobb, a legkisebb expressziójú +1-ben purint tartalmazó GC szekvenciák kétszeresét elérő expressziót biztosít. Eredményünk alapján látható, hogy az U6 promóternél a 2. nukleotid is rendkívül nagymértékben befolyásolja a keletkező RNS-ek mennyiségét, transzkriptálódhat olyan mennyiségű RNS a +1 -es pozícióban pirimidinről is, mint purinról, ha megfelelő nukleotid követi, valamint a +1A-val, vagy $+1 \mathrm{G}$ vel keletkezett RNS-ek mennyiségében is lehet jelentős eltérés, ha a második pozícióban különböző nukleotidok szerepelnek.

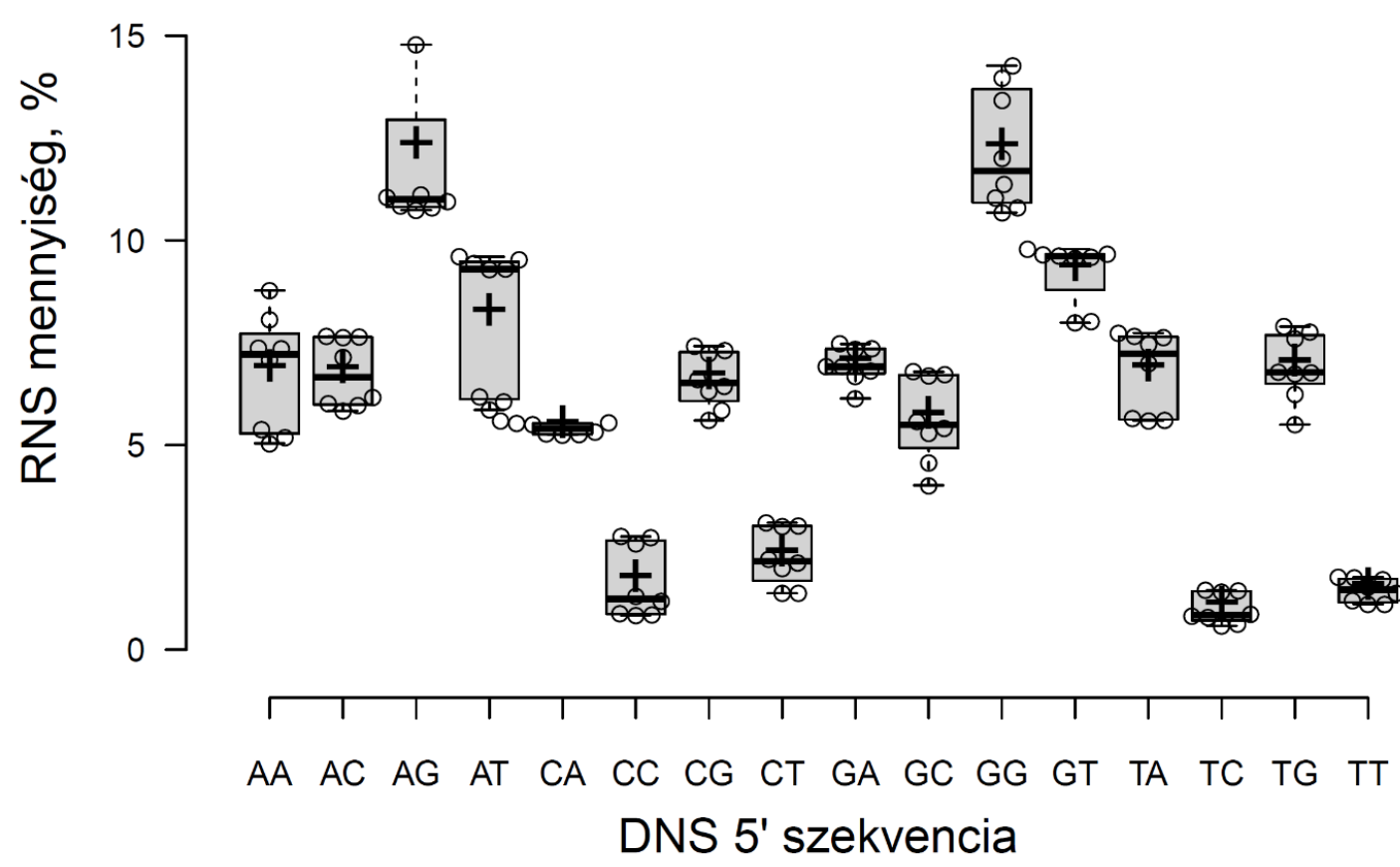

\section{5. Ábra. A promótertől downstream elhelyezkedő első két nukleotid hatása az RNS expresszióra}

Az ábrán a promótert követő első két nukleotid hatása látható az U6 promóterről termelődött RNS-ek mennyiségére. Az ábra az összes transzkripciós iniciációs pozíció transzkriptumainak mennyiségeit mutatja. 1 adatpont megadja az összes szekvenciáról termelődött RNS-ek összegéhez képest keletkezett RNS-ek százalékos arányát az adott szekvenciáról, adott cDNS könyvtáron belül. A boxokon belüli vastag vízszintes vonalak a mediánokat mutatják; a boxok határolják az R programmal meghatározott 25 . és 75 . percentilist; a szimpla vízszintes vonalak az interkvartilis tartomány 1,5 -szereséig terjednek ki a 25 . és 75 . percentilistől; a keresztek a minták átlagát mutatják; az adatpontok körökként vannak ábrázolva. $\mathrm{N}=8$, amely a $8 \mathrm{cDNS}$ könyvtárnak felel meg. A p értékek a Függelékben a 109. oldalon találhatók meg.

Mivel az eddig bemutatott eredmények alapján látható, hogy ha a +1 -es pozícióban pirimidin van, pirimidinekkel a transzkripciós iniciációs pozíciók sokkal heterogénebbek, ezért a további pozíciók szerepét az RNS mennyiségekre már csak +1A-val és +1 G-vel vizsgáltuk a továbbiakban. Az első 3 pozíció szekvenciáját vizsgálva azt kaptuk, hogy a legtöbb szignifikáns eltérés az AG kezdetűek és a többiek között van. AGT, AGG mindnél szignifikánsan jobb volt, kivéve a többi AG kezdetü variációnál (26. ábra). 
Az első 3 pozíció szekvenciáját vizsgálva +1 G-vel nagyobb különbségeket találtunk. A legtöbb különbség a GG kezdetű dinukleotidok és a többi variációjú dinukleotiddal kezdődő szekvenciák között van, és a GGG-vel kezdődő szekvenciák majdnem minden más szekvencia variációnál szignifikánsan több RNS-t eredményeznek. A GT kezdetü szekvenciákról keletkezett RNS mennyiségekben a +3 -as pozíció nukleotidjai is szignifikáns különbséget okoztak (26. ábra). Eredményeink alapján, ha a +1 -es és a +2 -es pozíciókban lévő dinukleotid megegyezik, viszont az azt követő pozíció nukleotidja más, az is különbségeket okozhat az RNS mennyiségekben.

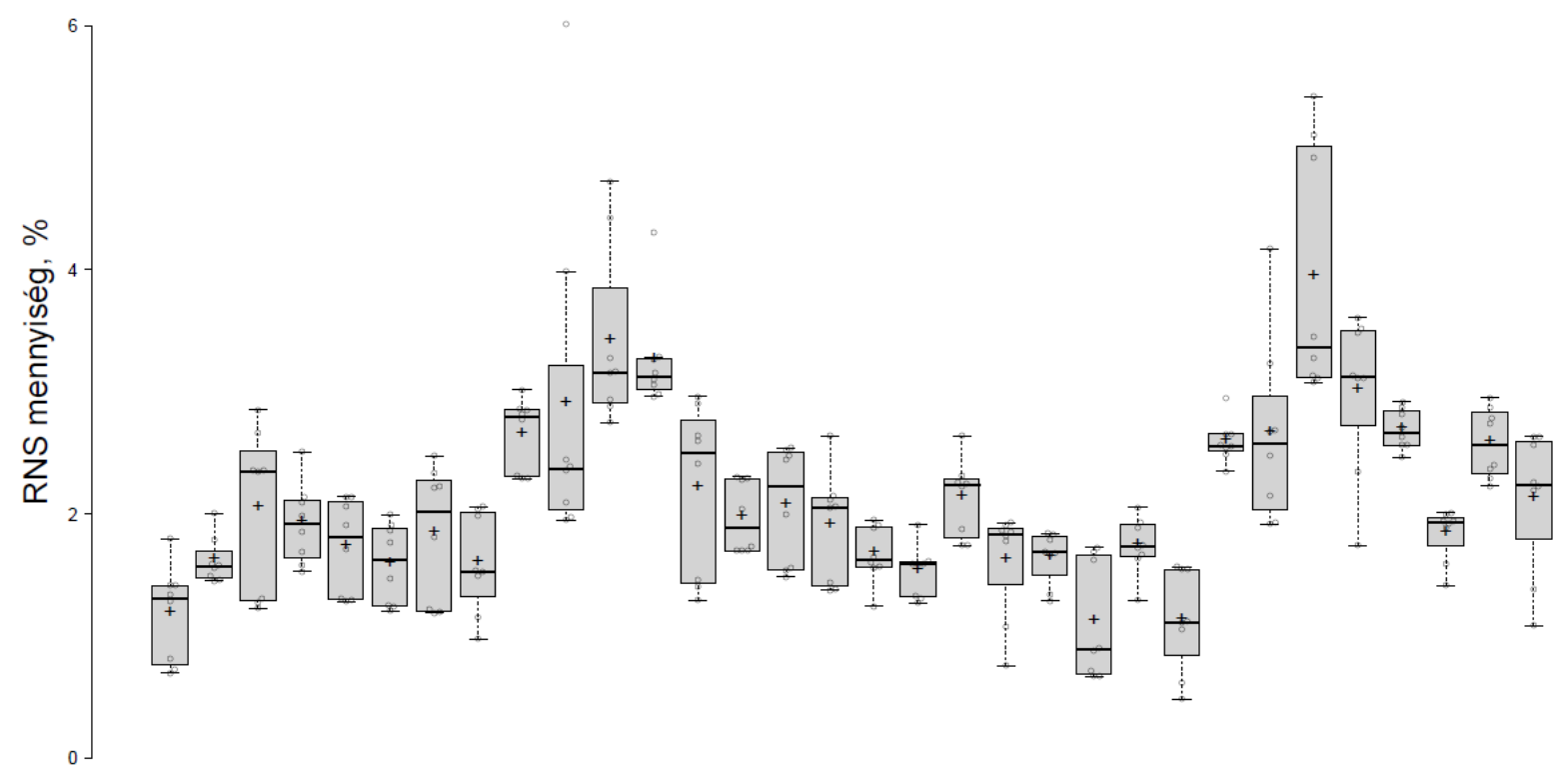

DNS 5' szekvencia
AAA AAC AAG AAT ACA ACC ACG ACT AGA AGC AGG AGT ATA ATC ATG ATT GAA GAC GAG GAT GCA GCC GCG GCT GGA GGC GGG GGT GTA GTC GTG GTT

26. Ábra. A promótertől downstream elhelyezkedő első három nukleotid hatása az RNS expresszióra, ha a +1-es pozícióban $A$ vagy $G$ van

$\mathrm{Az}$ ábrán a promótert követő első három nukleotid hatása látható az U6 promóterről termelödött RNS-ek mennyiségére, ha az első pozícióban $A$, vagy $G$ van. Az ábra az összes transzkripciós iniciációs pozíció transzkriptumainak mennyiségeit mutatja. 1 adatpont megadja az adott szekvenciáról keletkezett RNS-ek százalékos arányát az összes szekvenciáról termelődött RNS-ek összegéhez képest az adott cDNS könyvtárban. A boxokon belüli vastag vízszintes vonalak a mediánokat mutatják; a boxok határolják az $\mathrm{R}$ programmal meghatározott 25. és 75 . percentilist; a szimpla vízszintes vonalak az interkvartilis tartomány 1,5-szeresérég terjednek ki a 25. és 75. percentilistől,; a keresztek a minták átlagát mutatják; az adatpontok körökként vannak ábrázolva. N=8, amely a 8 cDNS könyvtárnak felel meg. A p értékek a Függelékben a 110-111. oldalon találhatók meg. 
A +4-es pozíció hatását is megvizsgáltuk az RNS expresszióra, és azt találtuk, hogy akár néhányszoros RNS mennyiségbeli különbségeket is képes okozni a 4. pozícióban elhelyezkedő bázis, ha az első 3 megegyezik, tehát még a +4-es pozícióban lévő nukleotid is befolyásolja a transzkripciót. A 27. ábrán látható, hogy a +4-es pozíció nem egyforma módon befolyásolja a transzkriptum mennyiségét, hanem a tőle upstream lévő szekvencia függvényében változóan.
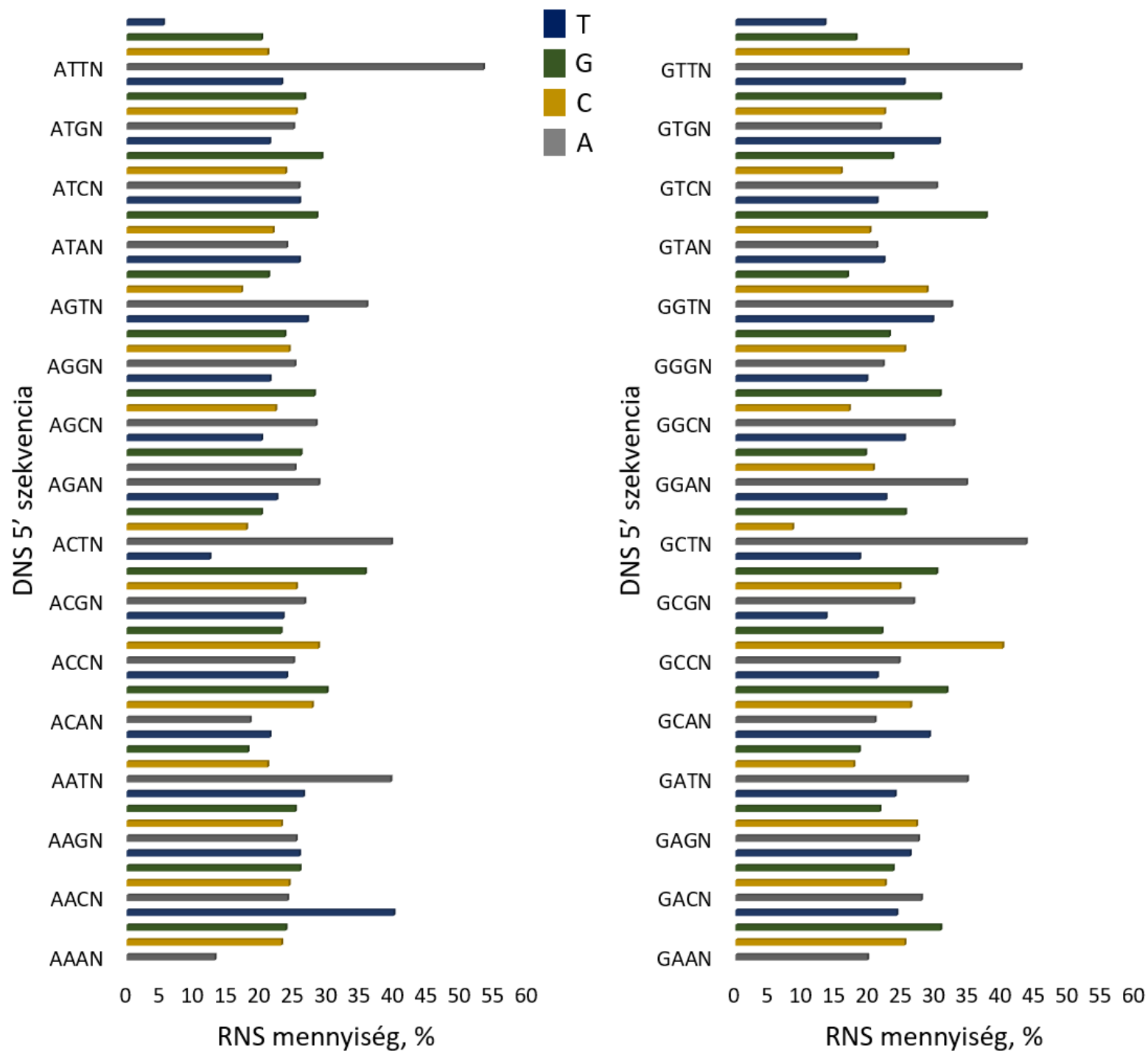

\section{7. Ábra. A +4-es pozícióban lévő nukleotidok hatása az RNS expresszióra, ha a +1 A, vagy G}

Az ábrán a +4-es pozícióban elhelyezkedő különbözö nukleotidok hatása látható az U6 promóterről termelödött RNS-ek mennyiségére, ha a +1-es pozícióban A vagy $\mathrm{G}$ van. Az ábra az összes transzkripció iniciációs pozíció transzkriptumainak mennyiségeit mutatja. 1 oszlop megadja, hogy a promótert követő 4 bázis adott szekvenciájáról, 8 db cDNS könyvtár alapján átlagosan hány \% RNS keletkezett az összes, első 3 pozíció szekvenciájában megegyezö, de 4. pozícióban más nukleotidot tartalmazó szekvenciáról termelödött RNS-ek összegéhez képest. 
A +1-es pozíciótól a +4-esig terjedő szekvencia függvényében a fenti ábrákon látható módon változó mennyiségü RNS expresszálódik az U6 promóterről. A legkisebb és a legnagyobb expressziót biztosító szekvenciákról termelődött RNS mennyiségek átlagai között közel 13x-os különbség van +1A-val (ATTT és AGTA) és több, mint 9x-es +1G-vel (GCTC és GGGT) (28. ábra).

Eredményeink alapján az U6 promóternél nemcsak a +1-es pozíció, hanem a továbbiak is befolyásolják a keletkező RNS-ek mennyiségét.
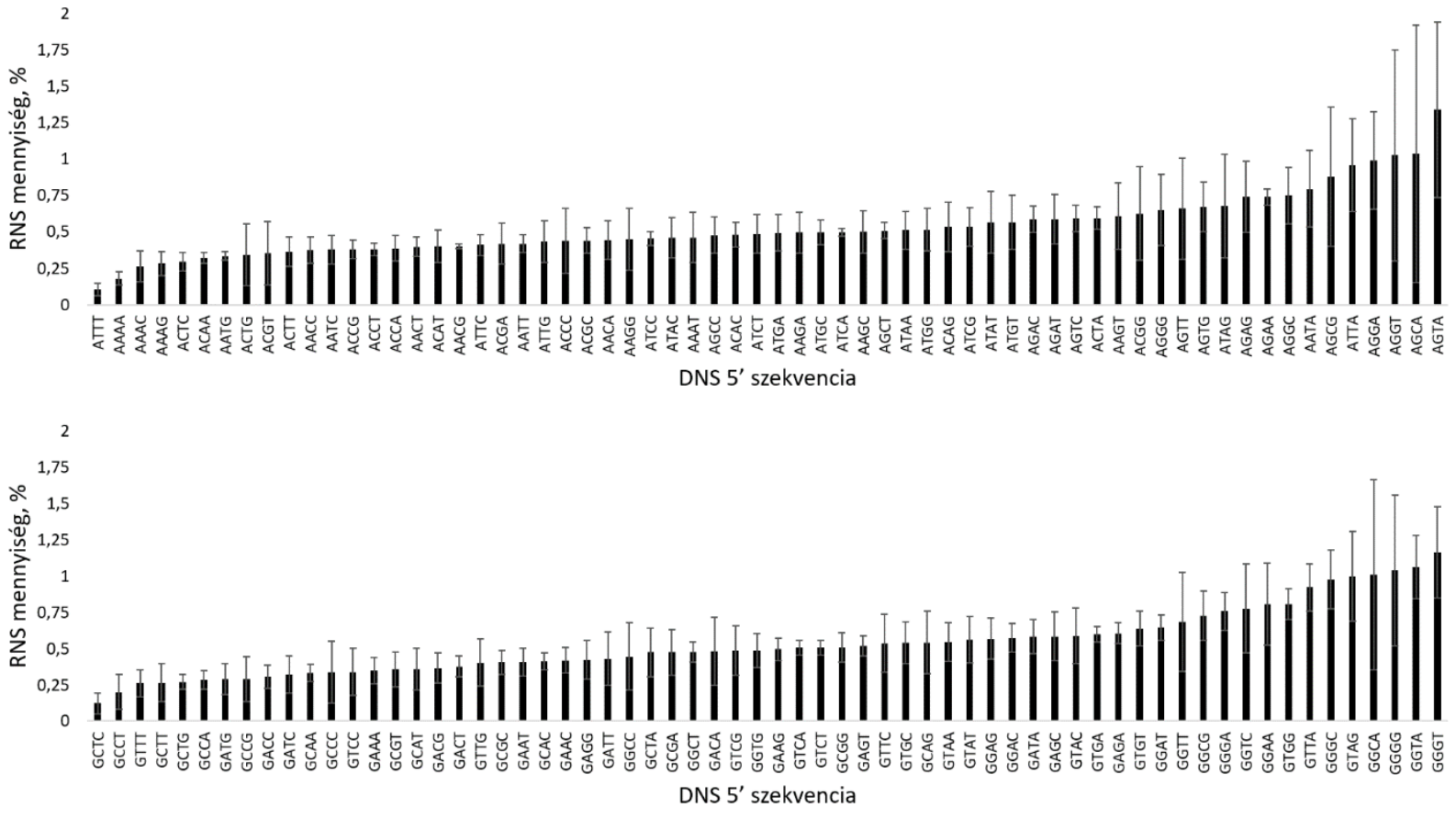

28. Ábra. Az U6 promótert downstream követő négy bázisos szekvencia hatása az RNS expresszióra, ha a +1 A vagy $G$

Az ábrán a +1-től a +4-es pozícióig terjedő szekvencia hatása látható az U6 promóterről termelődött RNS-ek mennyiségére, ha az első pozícióban $A$ vagy $G$ van. Az ábra az összes transzkripciós iniciációs pozíció transzkriptumainak mennyiségeit mutatja. 1 oszlop megadja, hogy az összes lehetséges szekvenciáról (256 variáció) termelődött RNS-ek összegéhez képest adott szekvenciáról az RNS-ek hány \%-a keletkezett átlagosan. A hibasávok a százalékos értékek átlagainak szórását mutatják. N=8, amely a 8 cDNS könyvtárnak felel meg.

\subsubsection{A 7sk promóter}

Az NGS eredményeink alapján először megvizsgáltuk az első nukleotid szerepét a transzkripciós iniciációs pozíciókra (29. ábra). Ha a +1-ben A volt, akkor az összes RNS átlag 86\%-a keletkezett a +1 pozícióról, $+1 \mathrm{G}-\mathrm{vel}$ ez $89 \%$ volt. Rendkívül kis arányban indul el pontosan az átírás, ha a +1 -ben pirimidin volt, a purinokhoz képest. $+1 \mathrm{C}$-vel 16\%, +1T-vel 13\% volt a +1-ről átíródott RNS-ek aránya. 


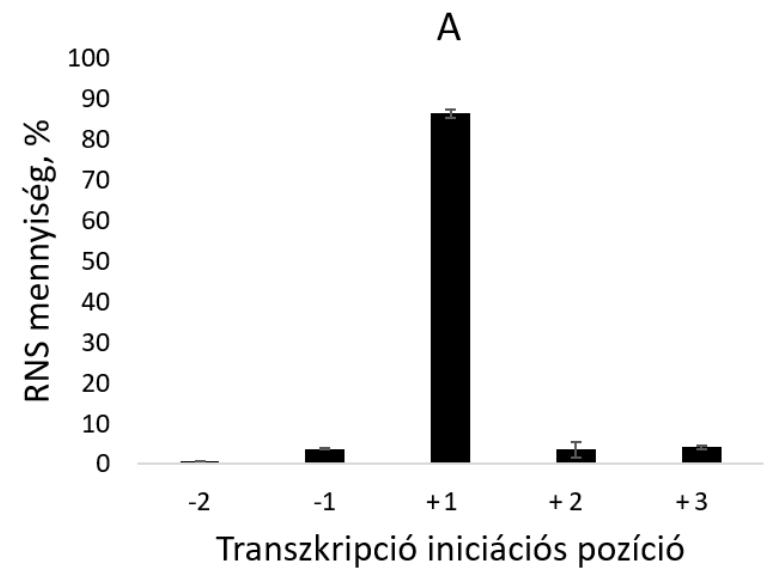

G

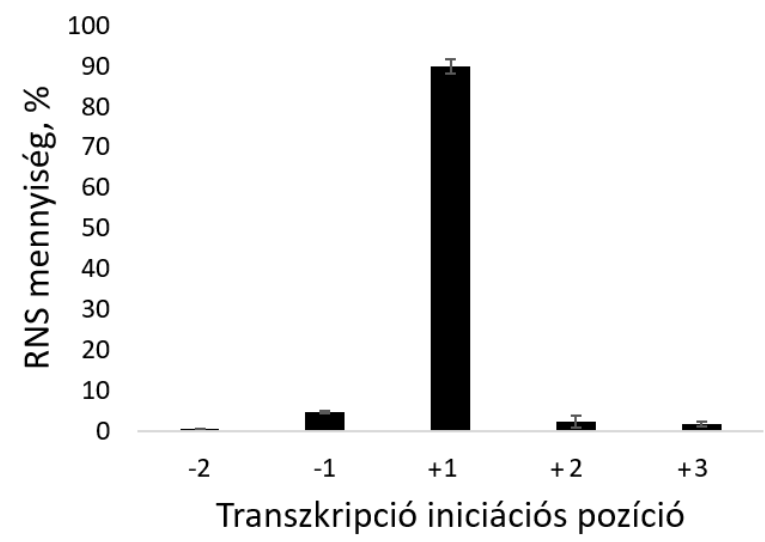

C

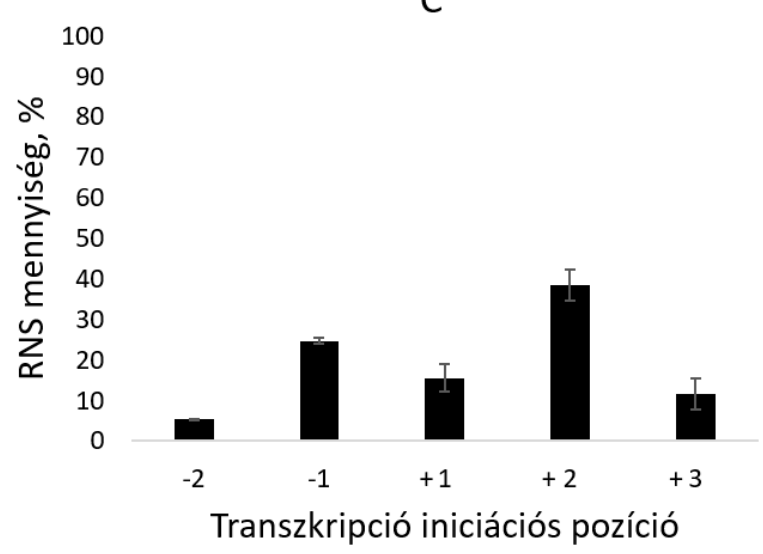

$\mathrm{T}$

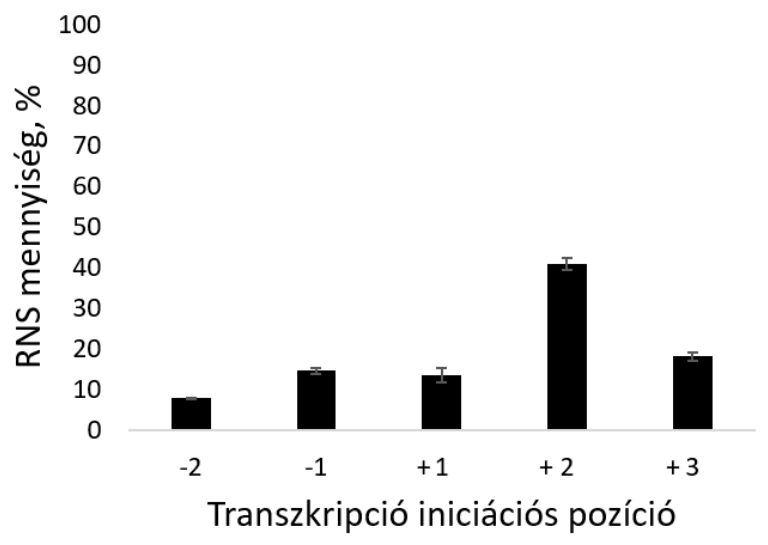

29. Ábra. A 7sk promótertől downstream elhelyezkedő első nukleotid hatása a különböző transzkripció iniciációs pozíciókra

Az ábrán látható, hogy a 7sk promótertől downstream elhelyezkedő első nukleotid miképp befolyásolja, hogy melyik pozícióról milyen arányban indul el az átírás. Egy oszlop megmutatja, hogy az összes vizsgált pozícióról termelődött RNS-ek összegének átlagban hány \%-a íródott át adott pozícióról. A hibasávok a százalékos értékek átlagainak szórását mutatják. $\mathrm{N}=9$, amely a $9 \mathrm{cDNS}$ könyvtárnak felel meg.

Ezután megvizsgáltuk a további pozíciókban lévő nukleotidok szerepét is a különböző transzkripciós kezdő pozíciókra (30. ábra). Azt találtuk, ha a +1 -es pozícióban purin van, a további pozíciók már nem befolyásolják olyan nagymértékben a transzkripciós kezdő pozíciót, az RNS-ek legnagyobbrészt a +1-ről íródnak át. Ha a +1-es pozíció első bázisa pirimidin, és a +2 purin, akkor nagyobb arányban indul el a +2-röl a transzkripció, mint a +1-ről, ilyenkor kimarad a +1-es nukleotid, és az átírás a következőröl indul el. Ha az első 2 bázis pirimidin, de a harmadik purin, szintén megfigyelhető, hogy megnő azoknak az RNS-eknek az aránya, ahol kimaradnak, nem íródnak át a kezdő pirimidint tartalmazó nukleotidok, hanem az átírás az első purint tartalmazó nukleotidról indul el. De ebben az esetben azoknak az RNS-eknek is megnő az aránya, amelyek 1 nukleotiddal hosszabbak és a -1-ről indulnak el (föleg +1C-vel). 


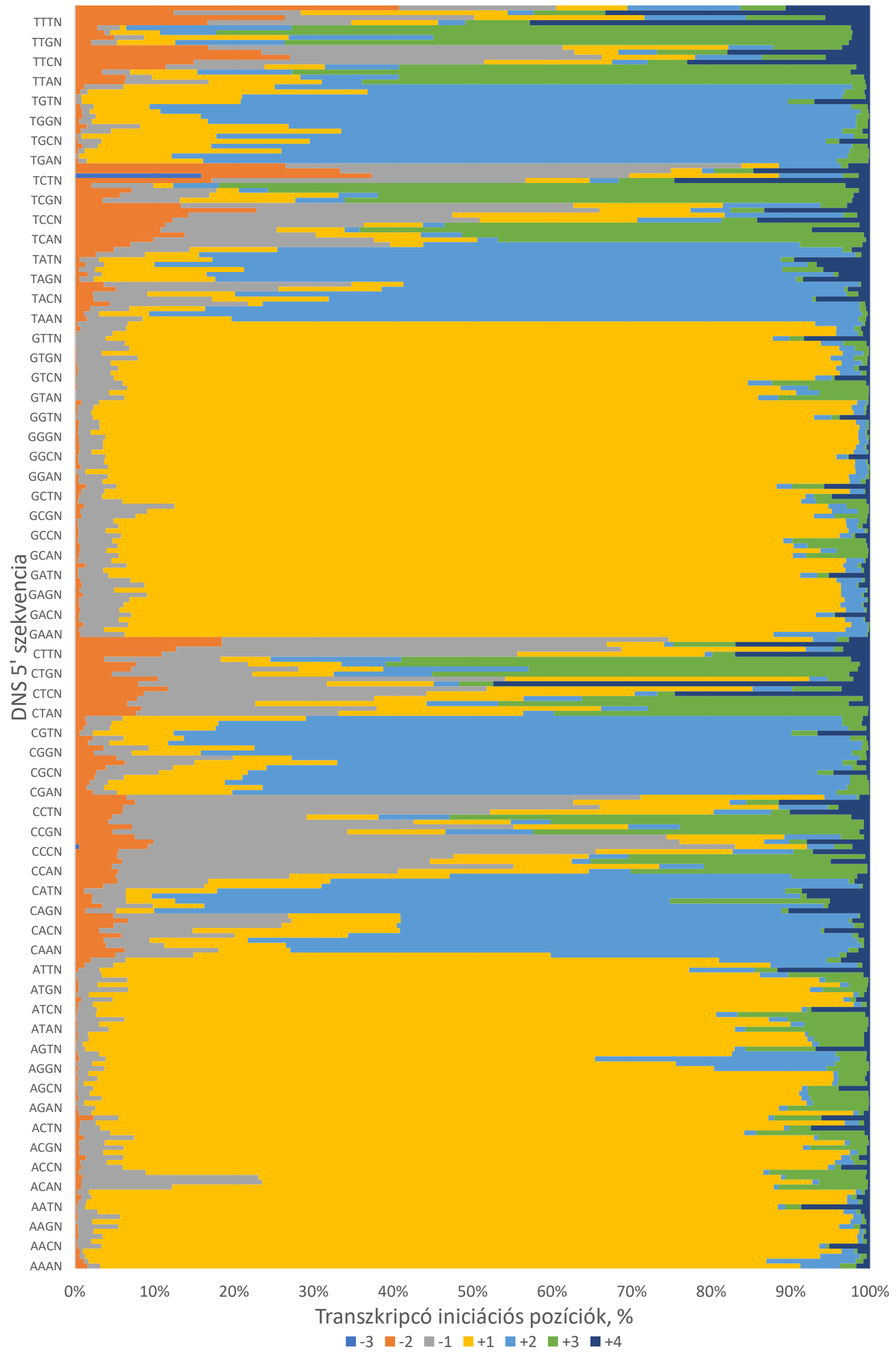


30. Ábra. A 7sk promótertől downstream elhelyezkedő szekvenciák hatása a különböző transzkripció iniciációs pozíciókra

Az ábrán látható, hogy a 7sk promótertől downstream elhelyezkedő szekvenciák miképp befolyásolják, hogy melyik pozícióról milyen arányban indul el az átírás. Egy oszlop egy színe megmutatja, hogy az összes vizsgált pozícióról termelődött RNS-ek összegének átlagban hány \%-a íródott át adott pozícióról, és egy oszlop egy darab kezdő szekvenciát jelöl. A közepesen világoskék szín a -3, a narancssárga szín a -2, a szürke szín a -1, a citromsárga szín a +1 , a világoskék szín a +2 , a zöld szín a +3 és a sötétkék szín a +4 pozíciókat jelöli a 7 sk promótertől downstream. $\mathrm{N}=9$, amely a 9 cDNS könyvtárnak felel meg.

A +1-es pozícióban A-val, vagy G-vel szinte csak jó hosszúságú RNS-ek keletkeztek, legnagyobb arányban a +1-ben kezdődik az átírás (31. ábra). Vannak olyan szekvenciák +1Aval, amelyiknél a +1-es pozícióról induló transzkripció aránya kevesebb, de +1A és +1G között nincs jelentős eltérés abban, hogy milyen arányban lesz a transzkripció iniciációs pozíció a +1 . Eredményeink azt mutatják, hogyha a 7sk promóter után az első pozícióban purin van, az átírás majdnem 100\%-ban a +1-ről indul el, és a kezdő pozíciót a további pozíciók nagyon kis mértékben befolyásolják. Ezzel szemben, ha a +1-ben pirimidin van, az átírás nemcsak +1-ről történik, és azt, hogy pirimidin esetében melyik pozícióról milyen arányban történik a transzkripció iniciációja, nagymértékben befolyásolják a promótertől downstream elhelyezkedő további nukleotidok is.
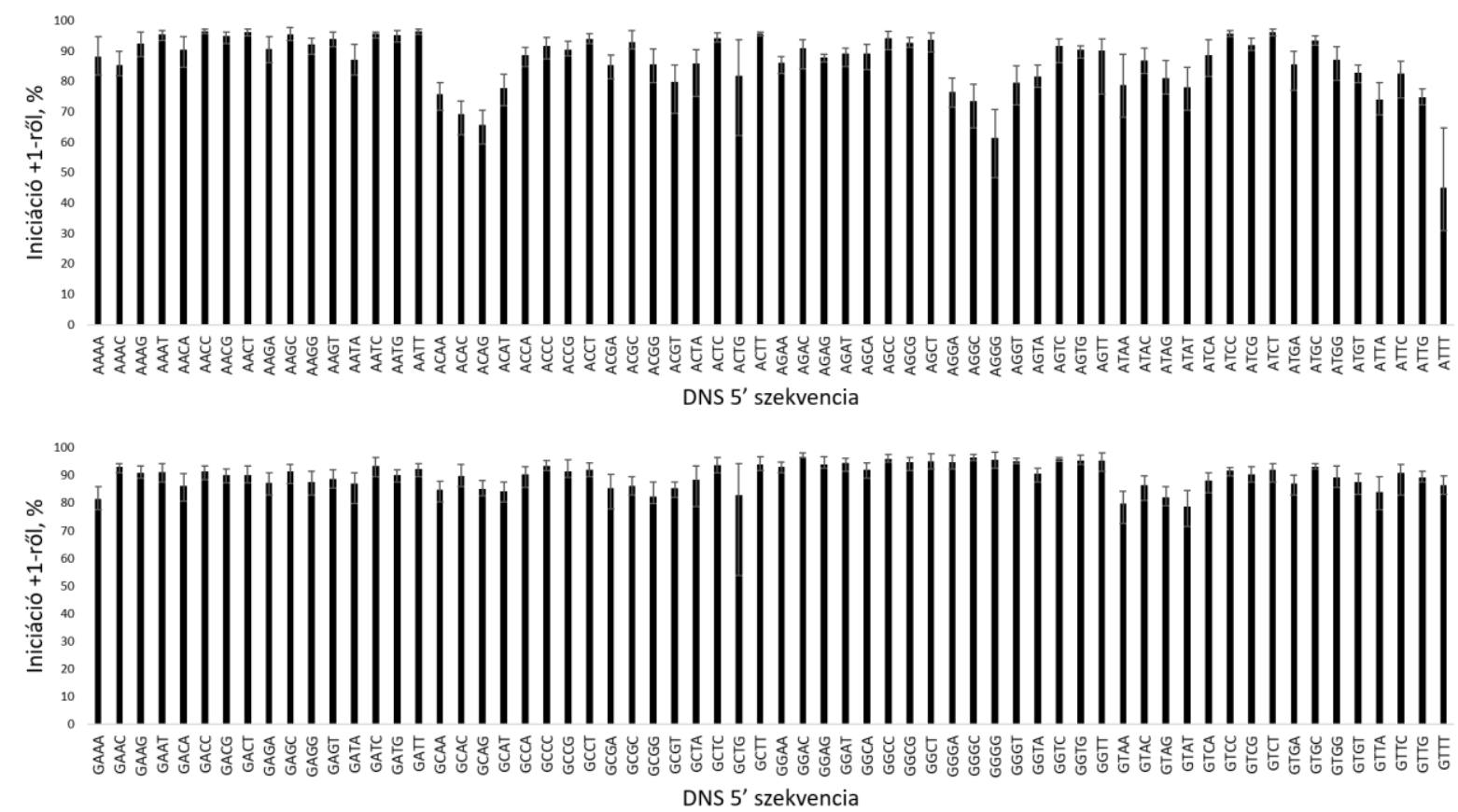

31. Ábra. A 7sk promótertől downstream lévő szekvenciák hatása a +1-ről induló transzkripcióra, ha a +1 A vagy $G$

Az ábrán a 7sk promóter után elhelyezkedő különböző szekvenciák szerepe látható a +1 pozícióról történő átírásra. Az oszlopok megmutatják, hogy átlagban hány \%-ban indult el +1-ről az átírás adott templát DNS szekvencia esetén. A hibasávok a százalékos értékek átlagainak szórását mutatják. N=9, amely a 9 cDNS könyvtárnak felel meg. 
A következő lépésekben azt néztük meg, hogy a 7sk promótertől downstream elhelyezkedő nukleotidok hogyan hatnak a transzkriptumok mennyiségére. Az első pozíció szerepét vizsgálva az átíródott RNS-ek mennyiségére azt találtuk, ha +1-ben purin van, szignifikánsan több RNS termelődik, mintha pirimidin. A purinokról és a pirimidinekröl keletkezett transzkriptumok mennyisége egymástól szignifikánsan eltér, a G szignifikánsan jobb, mint az A, kicsit több, mint 30\%-al. A 2 pirimidint egymással összehasonlítva viszont nincs szignifikáns különbség (32. ábra).

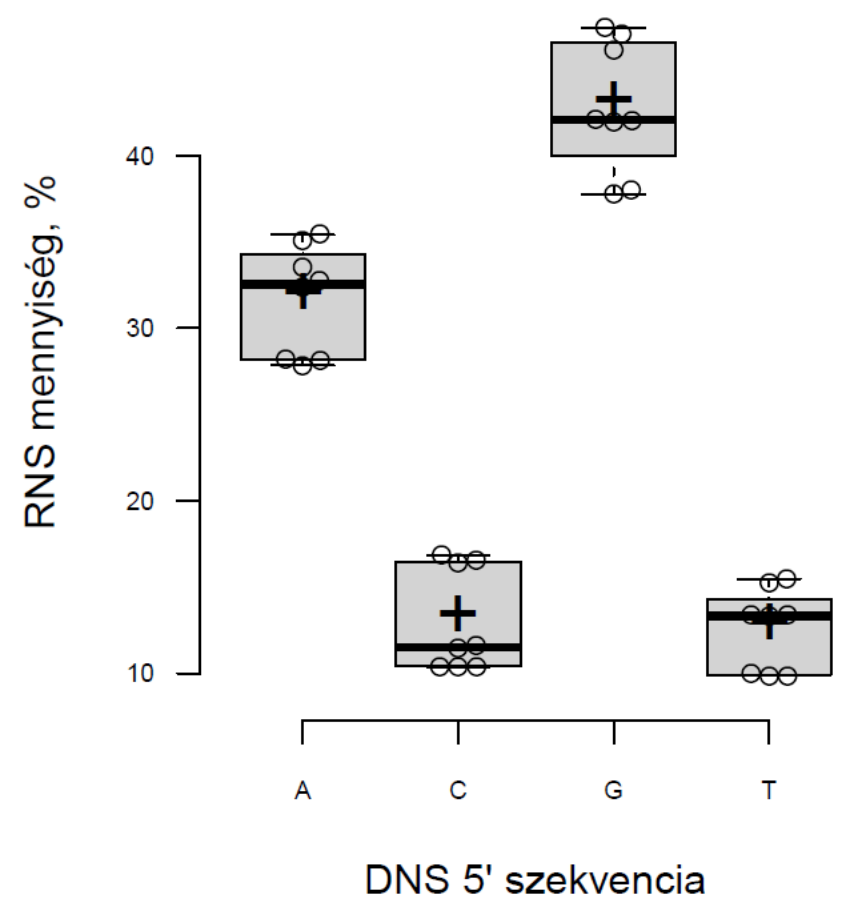

32. Ábra. A +1-es pozícióban lévő nukleotid hatása az RNS expresszióra

Az ábrán a +1-es pozícióban lévő nukleotid hatása látható a 7sk promóterről termelődött RNS-ek mennyiségére. Az ábra az összes transzkripciós iniciációs pozíció transzkriptumainak mennyiségeit mutatja. 1 adatpont megadja, hogy adott nukleotiddal az összes RNS hány \%-a keletkezett az adott cDNS könyvtáron belül. A boxokon belüli vastag vízszintes vonalak a mediánokat mutatják; a boxok határolják az R programmal meghatározott 25 . és 75 . percentilist; a szimpla vízszintes vonalak az interkvartilis tartomány 1,5-szereséig terjednek ki a 25 . és 75 . percentilistöl; a keresztek a minták átlagát mutatják; az adatpontok körökként vannak ábrázolva. N=9, amely a 9 cDNS könyvtárnak felel meg. A p értékek a Függelékben a 112. oldalon találhatók meg.

A 7sk promótertől downstream elhelyezkedő első 2 nukleotidot vizsgálva azt kaptuk, hogy a legtöbb RNS GG, AG, GT kezdettel keletkezik, és GG szignifikánsan mindegyiknél jobb, AG és GT között pedig nincs szignifikáns különbség (33. ábra). AG szignifikánsan több RNS-t eredményez, mint a többi olyan variáció, ahol a $+1 \mathrm{~A}$, illetve, $\mathrm{GG}$ is szignifikánsan jobb, minden egyéb +1 G variációnál, sőt a többi 15 variációnál is. +1 G-vel az összes többi verzió szignifikánsan különbözik egymástól, azonban +1A-val csak az AG szignifikánsan jobb a többinél, de azok egymástól nem különböznek. 
GA és GT szignifikánsan több RNS-t eredményez, mint az összes +1A, kivéve AG-t. GC-nél csak az AG szignifikánsan jobb, a többi +1A variációtól nem különbözik szignifikánsan. AG szignifikánsan jobb, mint az összes $+1 \mathrm{C}$ és $+1 \mathrm{~T}$, de AG kivételével az összes $+1 \mathrm{~A}$ verzió között és a CG, TG közt nincs szignifikáns különbség az RNS mennyiségekben. A legrosszabb G kezdetű (GC) nem különbözik szignifikánsan a legjobb C kezdetűtől (CG) és a legjobb T kezdetűtől (TG), de az összes többi G kezdetü jobb az összes többi C és T kezdetű verziónál. CC, CT, TC, TT szignifikánsan mindennél kevesebb RNS-t eredményeznek, csak egymásnál nem (33. ábra). A +1-ben purint tartalmazó három legnagyobb RNS mennyiséget okozó kezdő dinukleotid mindegyikéről minimum kétszer magasabb RNS szint érhető el átlagban, mint a legalacsonyabb RNS szintet biztosító purin kezdetű dinukleotidról. Eredményünk alapján a 7sk promóternél a +2-es pozíció is rendkívül nagymértékben befolyásolja a keletkező RNS-ek mennyiségét, transzkriptálódhat olyan mennyiségü RNS +1pirimidinről is, mint purinról, ha megfelelő nukleotid követi, valamint a +1A-val, vagy +1G-vel keletkezett RNS-ek mennyiségében is lehet jelentős eltérés, ha a +2-es pozícióban különböző nukleotidok vannak.

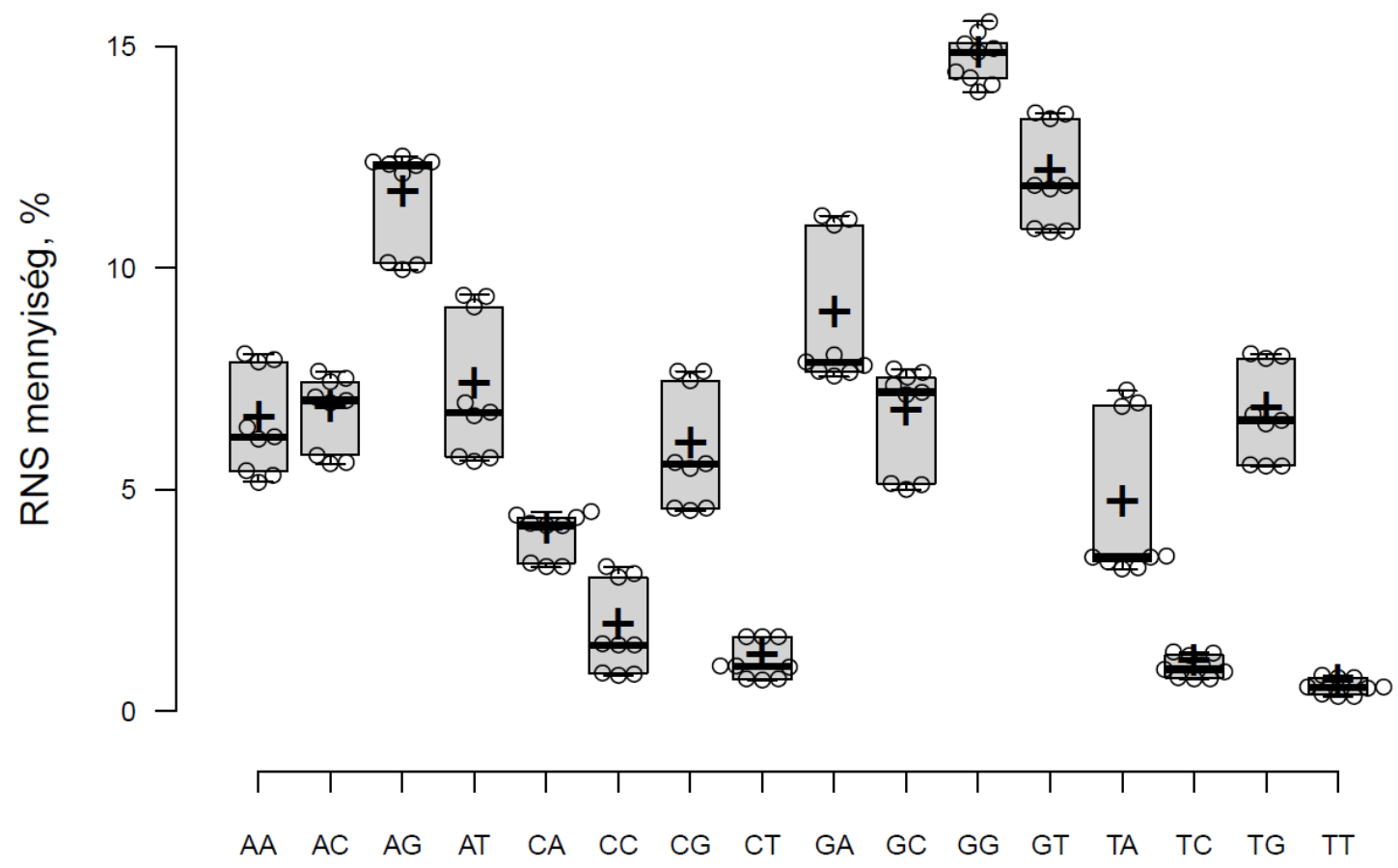

DNS 5' szekvencia

\section{3. Ábra. A promótertől downstream elhelyezkedő első két nukleotid hatása az RNS expresszióra}

Az ábrán a promótert követő első két nukleotid hatása látható a 7sk promóterről termelődött RNS-ek mennyiségére. Az ábra az összes transzkripciós iniciációs pozíció transzkriptumainak mennyiségeit mutatja. 1 adatpont megadja az összes szekvenciáról termelődött RNS-ek összegéhez képest keletkezett RNS-ek százalékos arányát az adott szekvenciáról, adott cDNS könyvtáron belül. A boxokon belüli vastag vízszintes vonalak a mediánokat mutatják; a boxok határolják az R programmal meghatározott 25 . és 75 . percentilist; a szimpla vízszintes vonalak az interkvartilis tartomány 1,5 -szereséig terjednek ki a 25 . és 75 . percentilistől; a keresztek a minták átlagát mutatják; az adatpontok körökként vannak ábrázolva. N=9, amely a 9 cDNS könyvtárnak felel meg. A p értékek a Függelékben a 112. oldalon találhatók meg. 
Mivel az eddig bemutatott eredmények alapján látható, hogy ha a +1-es pozícióban pirimidin van, a transzkripciós iniciációs kezdő pozíciók sokkal heterogénebbek, ezért a további pozíciók szerepét az RNS mennyiségekre már csak +1A-val és +1 G-vel mutatom be a továbbiakban.

Ha a promótertől downstream elhelyezkedő első 3 pozíció szekvenciáját vizsgáltuk, azt kaptuk, hogy +1 A-val a legtöbb különbség az AG kezdetü dinukleotidok és a többi $+1 \mathrm{~A}$ kezdetü variáció között van. Az első 3 pozíció szekvenciáját vizsgálva +1 G-vel azt találtuk, hogy a +3as pozícióban elhelyezkedő nukleotid is képes szignifikáns különbségeket okozni az RNS mennyiségben. A legtöbb szignifikáns különbség a GG és GT kezdetü dinukleotidok és a többiek között van (34. ábra). Eredményeink alapján a 7sk promóternél ha a promótertől downstream az első 2 pozícióban ugyanaz a dinukleotid van, viszont az azt követő pozícióban más nukleotid van, szignifikáns különbségeket képes okozni az RNS mennyiségekben. Eredményeink alapján a +1-es pozícióban a G egy kicsivel jobb RNS expresszióhoz vezethet, mint az A, de a további szekvencia függvényében +1A-ról is keletkezhet ugyanannyi, vagy több RNS, mint +1G-ről (lásd 33. és a 34. ábrák).

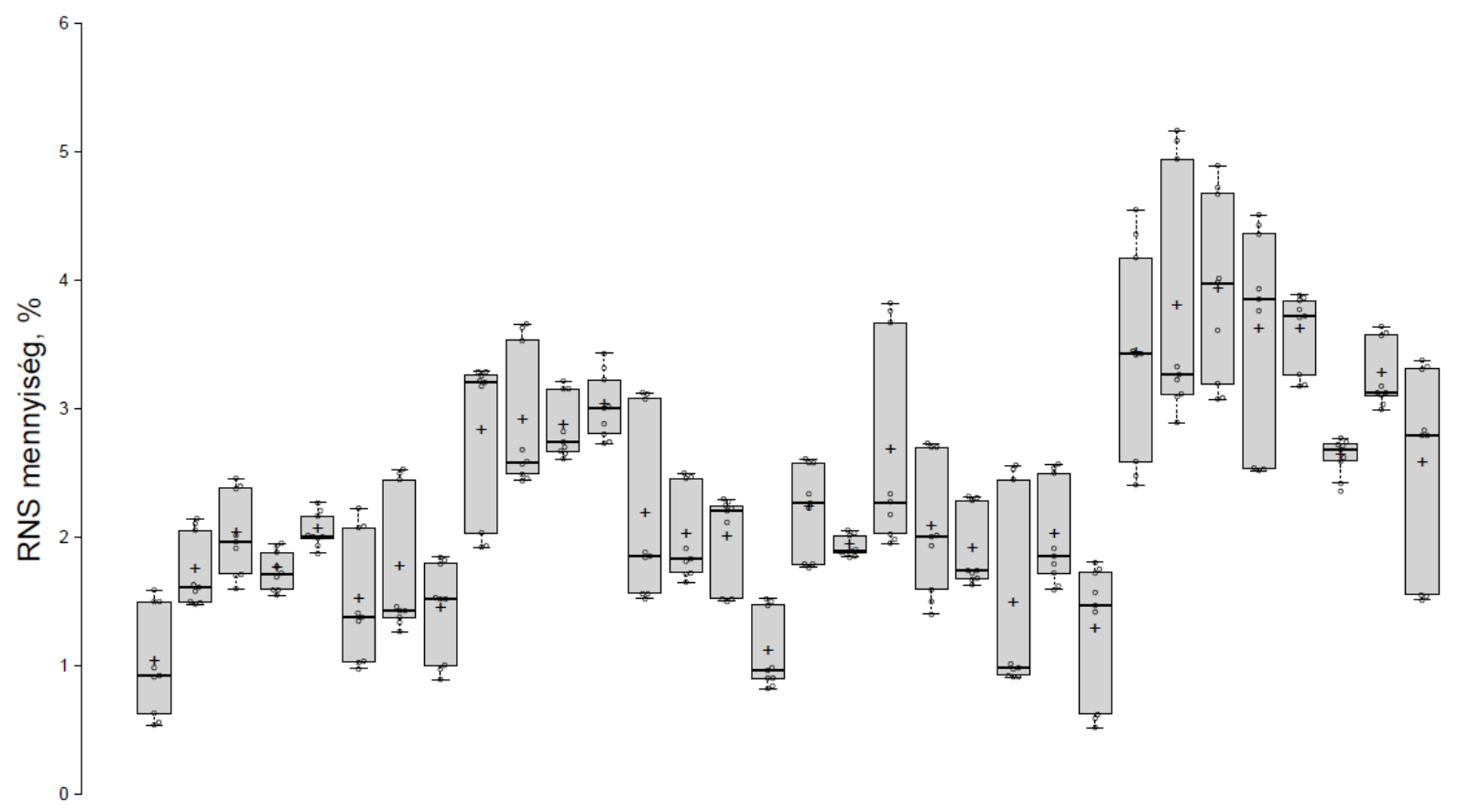

DNS 5 ' szekvencia
aAA AAC AAG AAT ACA ACC ACG ACT AGA AGC AGG AGT ATA ATC ATG ATT GAA GAC GAG GAT GCA GCC GCG GCT GGA GGC GGG GGT GTA GTC GTG GIT

34. Ábra. A promótertől downstream elhelyezkedő első három nukleotid hatása az RNS expresszióra, ha a +1-es pozícióban $A$ vagy $G$ van 
Az ábrán a promóterttől downstream elhelyezkedő első három pozícióban lévő nukleotidok hatása látható a 7sk promóterről termelödött RNS-ek mennyiségére, ha az első pozícióban A vagy $\mathrm{G}$ van. Az ábra az összes transzkripciós iniciációs pozíció transzkriptumainak mennyiségeit mutatja. 1 adatpont megadja az adott szekvenciáról keletkezett RNS-ek százalékos arányát az összes szekvenciáról termelödött RNS-ek összegéhez képest az adott cDNS könyvtárban. A boxokon belüli vastag vízszintes vonalak a mediánokat mutatják; a boxok határolják az R programmal meghatározott 25. és 75. percentilist; a szimpla vízszintes vonalak az interkvartilis tartomány 1,5-szeresérég terjednek ki a 25. és 75. percentilistől; a keresztek a minták átlagát mutatják; az adatpontok körökként vannak ábrázolva. N=9, amely a 9 cDNS könyvtárnak felel meg. A p értékek a Függelékben a 113-114. oldalon találhatók meg.

A +4-es pozíció hatását is megvizsgáltuk az RNS expresszióra, és azt találtuk, hogy az U6 promóterhez hasonlóan akár néhányszoros RNS mennyiségbeli különbségeket is képes okozni az ebben a pozícióban elhelyezkedő bázis is, ha a tőle upstream elhelyezkedő 3 bázis megegyezik. A 35. ábrán látható, hogy a +4-es pozíció az előtte lévő szekvencia függvényében változó mértékben befolyásolja az expressziós szintet.
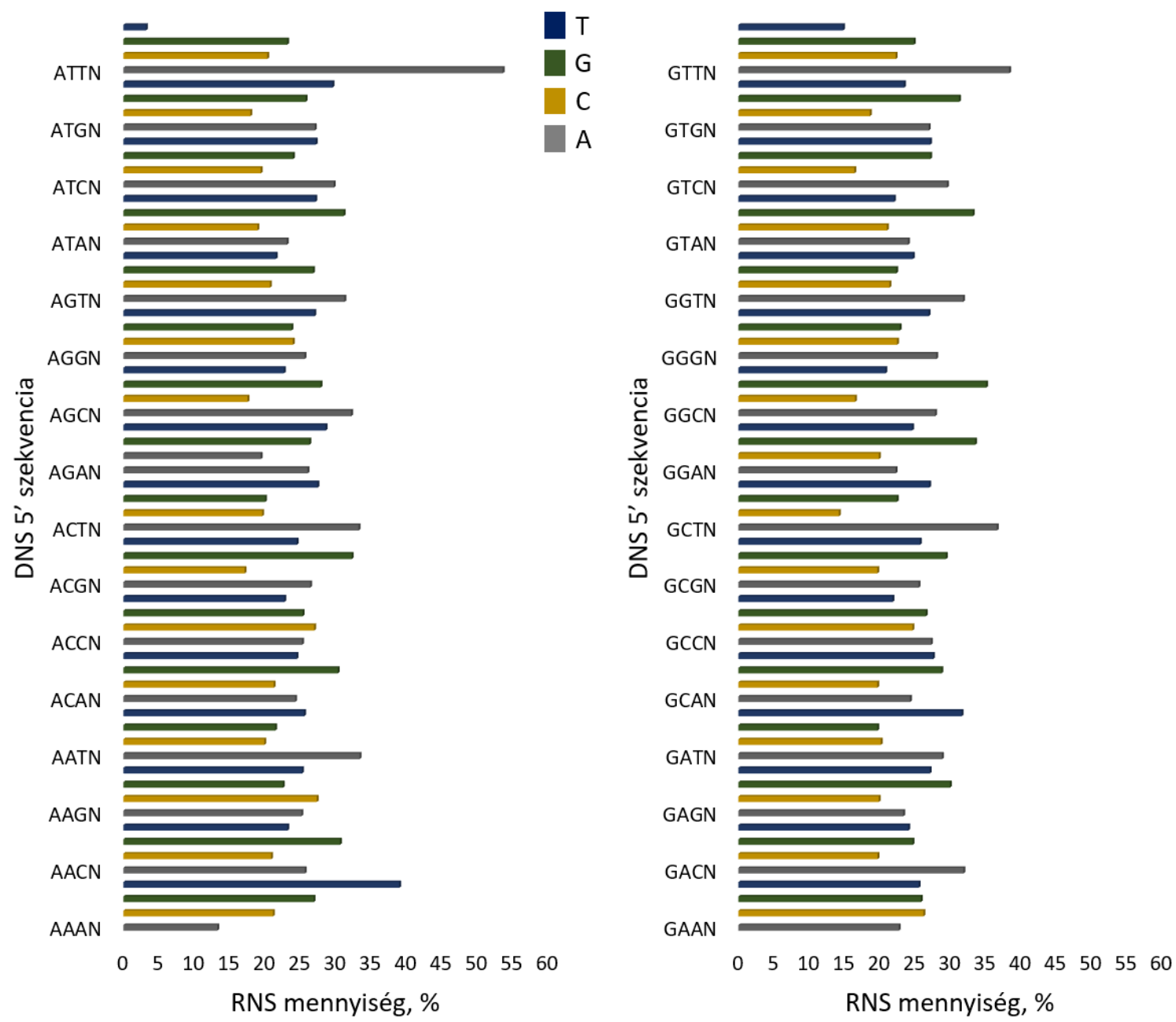

\section{5. Ábra. A +4-es pozícióban lévő nukleotidok hatása az RNS expresszióra, ha a +1 A vagy G}

Az ábrán a +4-es pozícióban elhelyezkedő különböző nukleotidok hatása látható a 7sk promóterről termelödött RNS-ek mennyiségére, ha a +1-es pozícióban A vagy $\mathrm{G}$ van. Az ábra az összes transzkripció iniciációs pozíció transzkriptumainak mennyiségeit mutatja. 1 oszlop megadja, hogy a promótert követő 4 bázis adott szekvenciájáról, 9 db cDNS könyvtár alapján átlagosan hány \% RNS keletkezett az összes, első 3 pozíció szekvenciájában megegyezö, de 4. pozícióban más nukleotidot tartalmazó szekvenciáról termelödött RNS-ek összegéhez képest. 
A promótert downstream követő első 4 nukleotid szekvenciájának függvényében a fenti eredményeken látható módon változó mennyiségű RNS expresszálódik a 7sk promóterről. A legkisebb és a legnagyobb expressziót biztosító szekvenciákról termelődött RNS mennyiségek átlagai között közel 27x-es különbség van +1A-val (ATTT és AGTA) és több, mint 7x-es +1Gvel (GCTC és GGCG) (36. ábra).

Eredményeink alapján a 7sk promóternél nemcsak a +1-es pozíció, hanem a továbbiak is befolyásolják a keletkező RNS-ek mennyiségét.
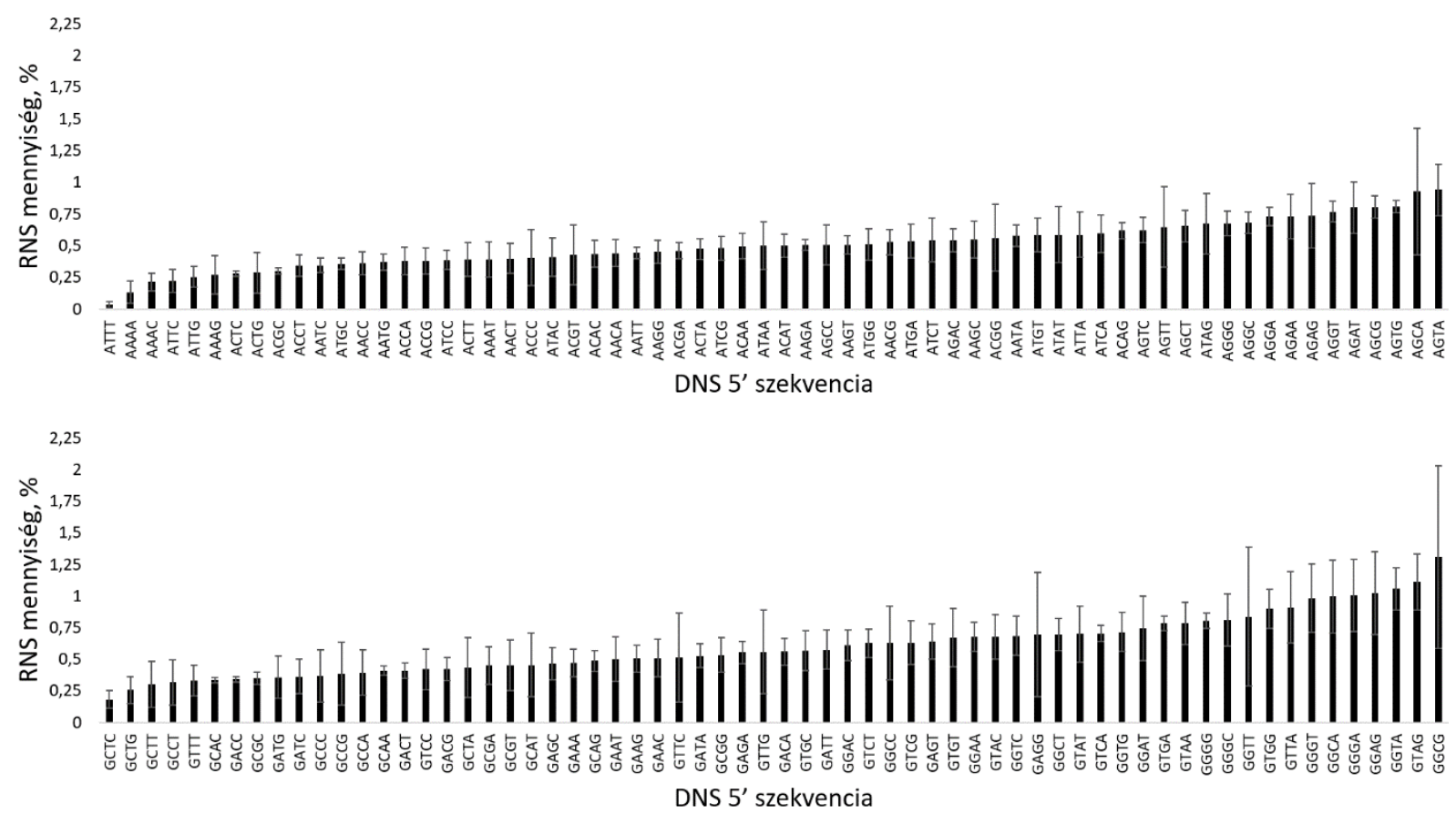

36. Ábra. A 7sk promótert downstream követő négy bázisos szekvencia hatása az RNS expresszióra, ha a +1 A vagy $G$

Az ábrán a +1-töl a +4-es pozícióig terjedő szekvencia hatása látható a 7sk promóterről termelődött RNS-ek mennyiségére, ha az első pozícióban $A$, vagy $\mathrm{G}$ van. Az ábra az összes transzkripciós iniciációs pozíció transzkriptumainak mennyiségeit mutatja. 1 oszlop megadja, hogy az összes lehetséges szekvenciáról (256 variáció) termelödött RNS-ek összegéhez képest adott szekvenciáról az RNS-ek hány \%-a keletkezett átlagosan. A hibasávok a százalékos értékek átlagainak szórását mutatják. N=9, amely a 9 cDNS könyvtárnak felel meg.

\subsubsection{A T7 promóter}

Az NGS eredményeink alapján először megvizsgáltuk a +1-es pozícióban lévő nukleotid szerepét a transzkripciós iniciációs kezdő pozíciókra (37. ábra). Ha a +1-ben A volt, akkor az összes RNS átlag 56\%-a keletkezett a +1 pozícióról, +1G-vel ez 90\% volt. Rendkívül kis arányban indul el pontosan az átírás, a purinokhoz képest, ha a +1 pirimidin, $+1 \mathrm{C}$-vel $30 \%$, +1T-vel 26\% volt a +1-ről átíródott RNS-ek aránya. 

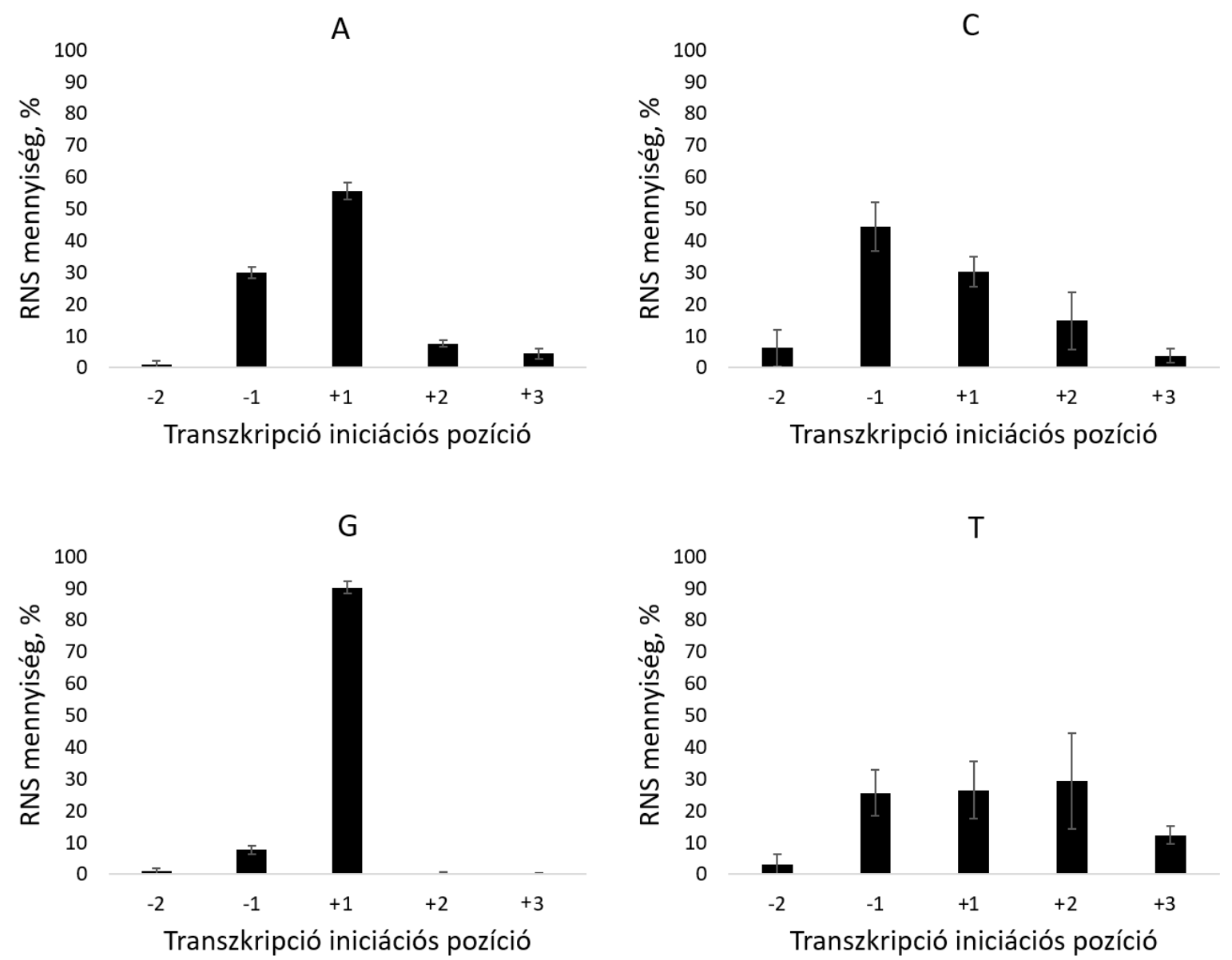

37. Ábra. A T7 promótertől downstream elhelyezkedő első nukleotid hatása a különböző transzkripció iniciációs pozíciókra

Az ábrán látható, hogy a T7 promótertől downstream elhelyezkedő első nukleotid miképp befolyásolja, hogy melyik pozícióról milyen arányban indul el az átírás. Egy oszlop megmutatja, hogy az összes vizsgált pozícióról termelödött RNS-ek összegének átlagban hány \%-a íródott át adott pozícióról. A hibasávok a százalékos értékek átlagainak szórását mutatják. $\mathrm{N}=9$, amely a 9 cDNS könyvtárnak felel meg.

Ezután megvizsgáltuk, hogy a további pozíciókban lévő nukleotidok hogyan befolyásolják a különböző transzkripciós kezdő pozíciókat. Azt találtuk, ha a +1-es pozícióban guanin van, a további pozíciók már nem befolyásolják olyan nagymértékben a kezdő pozíciót, az RNS-ek legnagyobbrészt +1-ről íródnak át (38-40. ábra). Ha a promótertől downstream elhelyezkedő első pozícióban pirimidin van, akkor nagyobb arányban indul el vagy a -1-ről, vagy a +2-ről a transzkripció, mint a +1-ről, és számítanak a további pozíciók is abban, hogy melyik pozícióról milyen arányban indul el az átírás (39. ábra). 

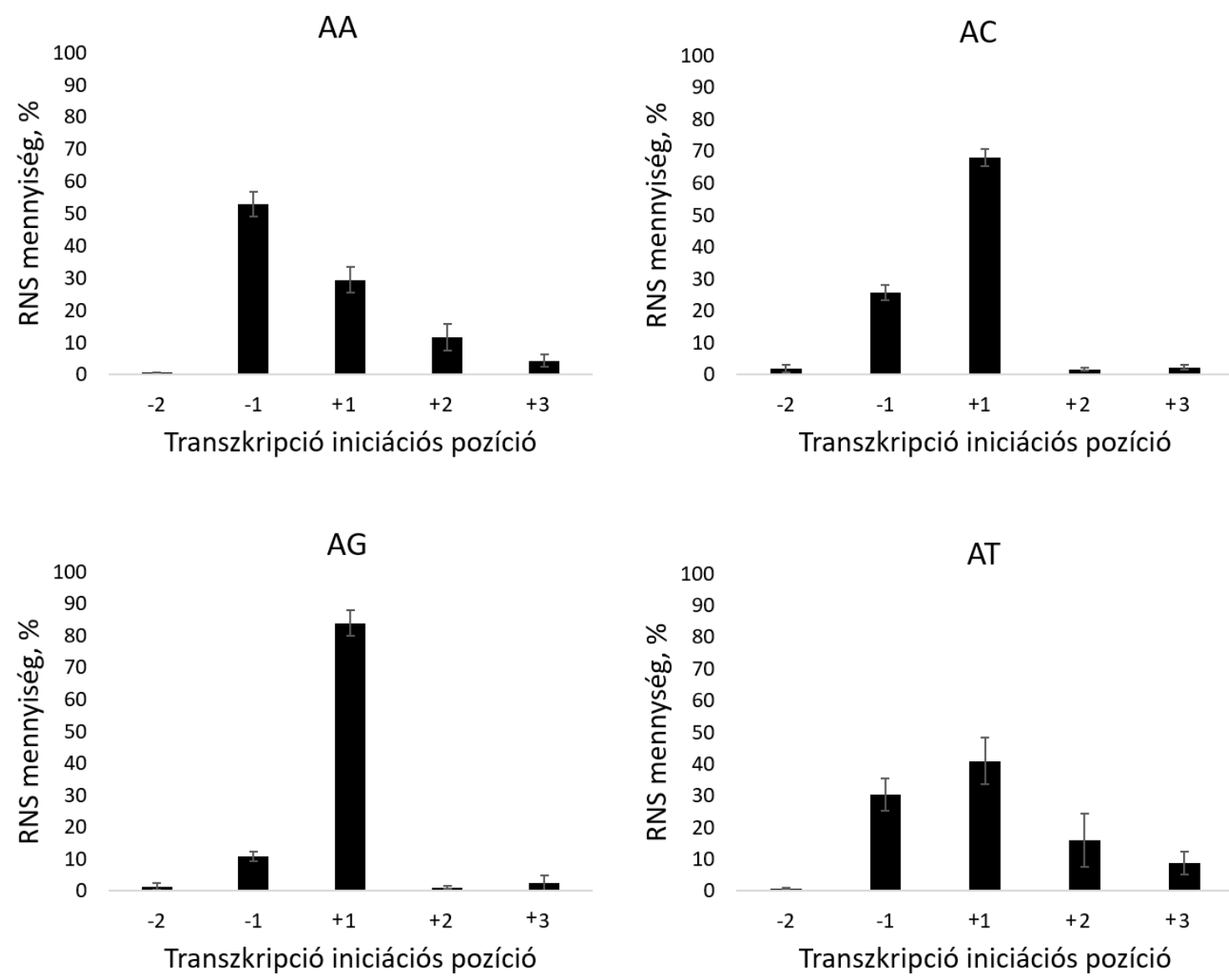

38. Ábra. A +2-es pozíció nukleotidjának hatása a különböző transzkripció iniciációs pozíciókra, ha a +1 A Az ábrán látható, hogy a +2-es pozíció nukleotidja miképp befolyásolja, hogy melyik pozícióról milyen arányban indul el az átírás, ha a $+1 \mathrm{~A}$. Egy oszlop megmutatja, hogy az összes vizsgált pozícióról termelődött RNS-ek összegének átlagban hány \%-a íródott át adott pozícióról. A hibasávok a százalékos értékek átlagainak szórását mutatják. $\mathrm{N}=9$, amely a 9 cDNS könyvtárnak felel meg.

Míg +1G-vel szinte csak jó hosszúságú RNS-ek keletkeztek, legnagyobb arányban a +1-ben kezdődik az átírás, addig +1A-val a további pozíciók is eltéréseket okoztak (39-40. ábra). Ha a promótertől downstream az első nukleotid A, akkor a 2. pozícióban lévő nukleotid is nagy szerepet játszik a különböző transzkripciós iniciációs kezdőhelyekre: míg AA-ról csak átlagosan 29, AT-ről 41, addig AC-ről 68, AG-ről pedig 84 \%-ban a +1-röl indul el az átírás (38. ábra). A +1-ben A-val a 39. és a 40. ábrákon látható, hogy a további pozíciók is szerepet játszanak abban, hogy melyik pozícióról milyen arányban indul el az átírás, hiába azonos az első 2 vagy 3 promótertől downstream elhelyezkedő pozíciók szekvenciája, de ha a +3 , vagy +4-es pozícióban különböző nukleotidok vannak, akkor jelentősen módosulhat a +1-ről átíródó RNS-ek százalékos aránya. 


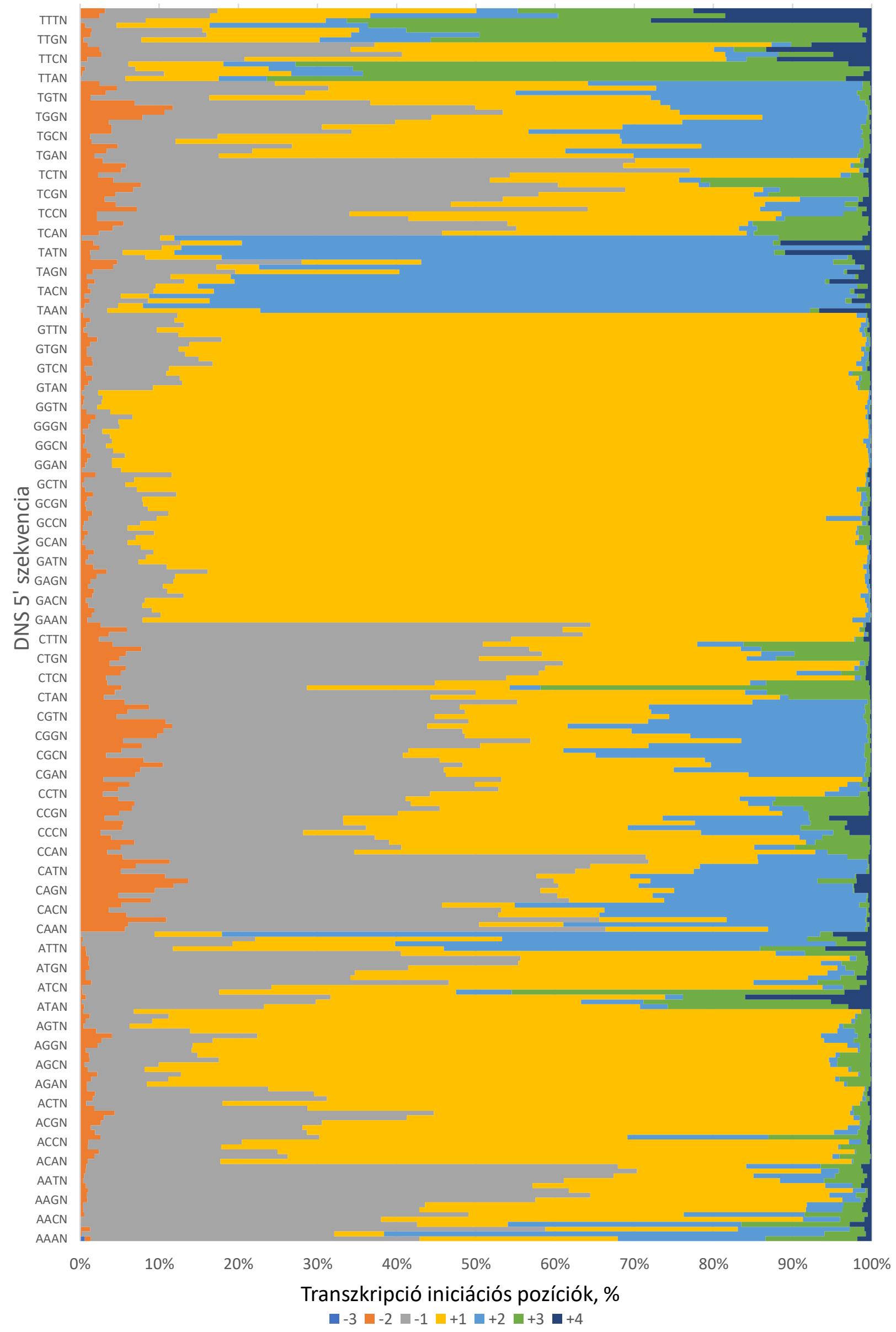


39. Ábra. A T7 promótertől downstream elhelyezkedő szekvenciák hatása a különböző transzkripció iniciációs pozíciókra

Az ábrán látható, hogy a T7 promótertől downstream elhelyezkedő szekvenciák miképp befolyásolják, hogy melyik pozícióról milyen arányban indul el az átírás. Egy oszlop egy színe megmutatja, hogy az összes vizsgált pozícióról termelődött RNS-ek összegének átlagban hány \%-a íródott át adott pozícióról, és egy oszlop egy darab kezdő szekvenciát jelöl. A közepesen világoskék szín a -3, a narancssárga szín a -2, a szürke szín a -1, a citromsárga szín a +1 , a világoskék szín a +2 , a zöld szín a +3 és a sötétkék szín a +4 pozíciókat jelöli a T7 promótertől downstream. $\mathrm{N}=9$, amely a 9 cDNS könyvtárnak felel meg.

Azt találtuk, hogy a +1-es pozícióról induló, pontos transzkripció az AG kezdő dinukleotidokról is elérhető, átlagosan 84\%-ban, amely majdnem eléri a +1-ben G-t tartalmazó szekvenciák pontosságát, az átlag 90\%-ot (37. és 38. ábra). Eredményeink alapján az AG kezdetü szekvenciákról a transzkripció iniciációs pozíciót a +3-4. pozíciók szekvenciája már nem befolyásolja jelentősen, a +1G kezdetű szekvenciákhoz hasonlóan (40. ábra).
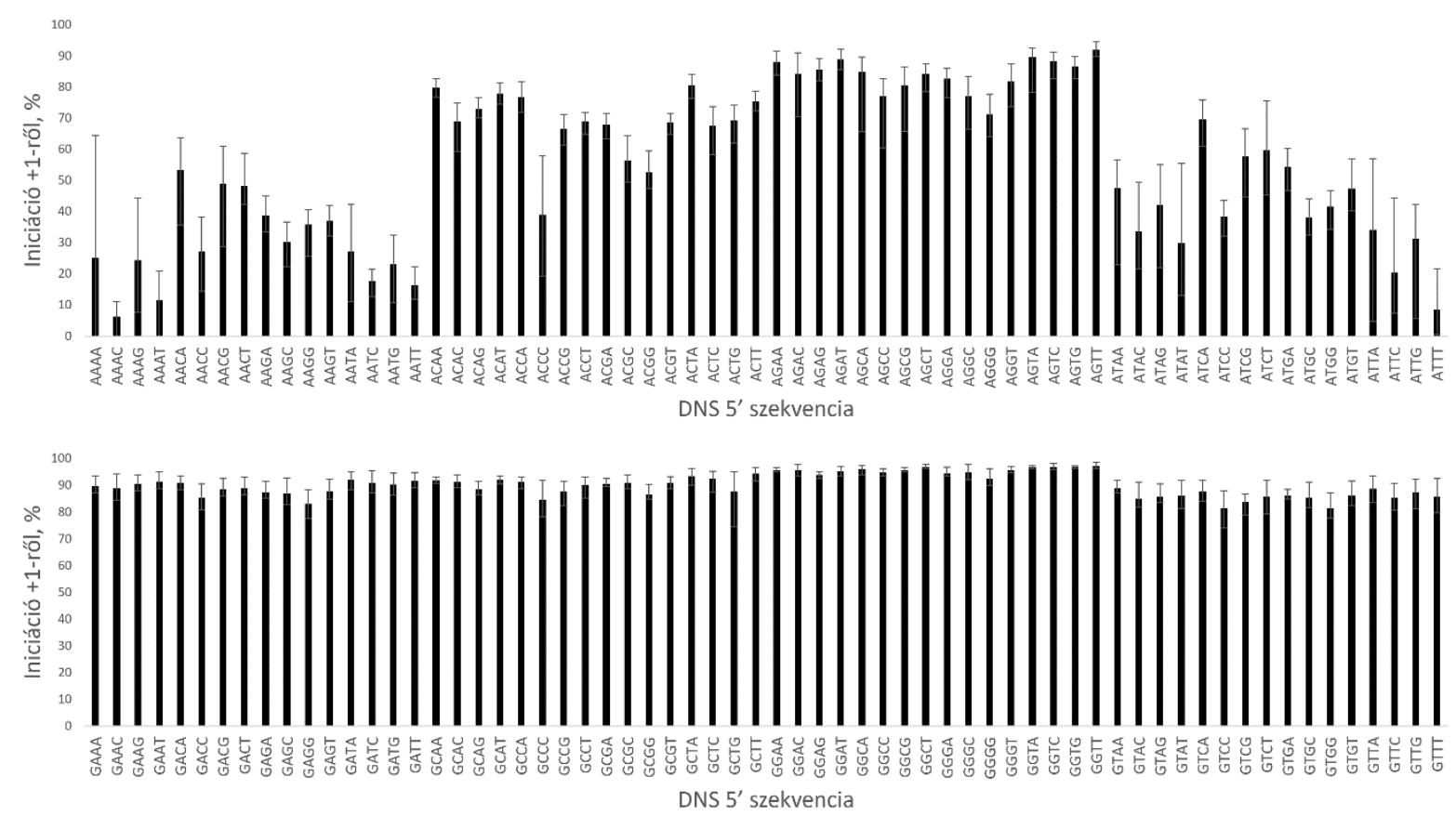

40. Ábra. A T7 promótertől downstream lévő szekvenciák hatása a +1-ről induló transzkripcióra, ha a +1 A, vagy G

Az ábrán a T7 promóter után elhelyezkedő különböző szekvenciák szerepe látható a +1 pozícióról történő átírásra. Az oszlopok megmutatják, hogy átlagban hány \%-ban indult el a +1-ről az átírás adott templát DNS szekvencia esetén. A hibasávok a százalékos értékek átlagainak szórását mutatják. $\mathrm{N}=9$, amely a 9 cDNS könyvtárnak felel meg.

A következő lépésekben azt néztük meg, hogy a T7 promótertől downstream elhelyezkedő nukleotidok hogyan hatnak a transzkriptumok mennyiségére. A +1 -es pozíció szerepét vizsgálva az átíródott RNS-ek mennyiségére azt találtuk, hogy ha a promóter után az első bázis purin, több RNS termelődik, mintha az első bázis pirimidin lenne.

Az első pozíciót vizsgálva a különböző kezdő nukleotidokról keletkezett transzkriptumok mennyisége egymástól szignifikánsan eltér, és a legtöbb RNS +1G-ről jött létre (41. ábra). 


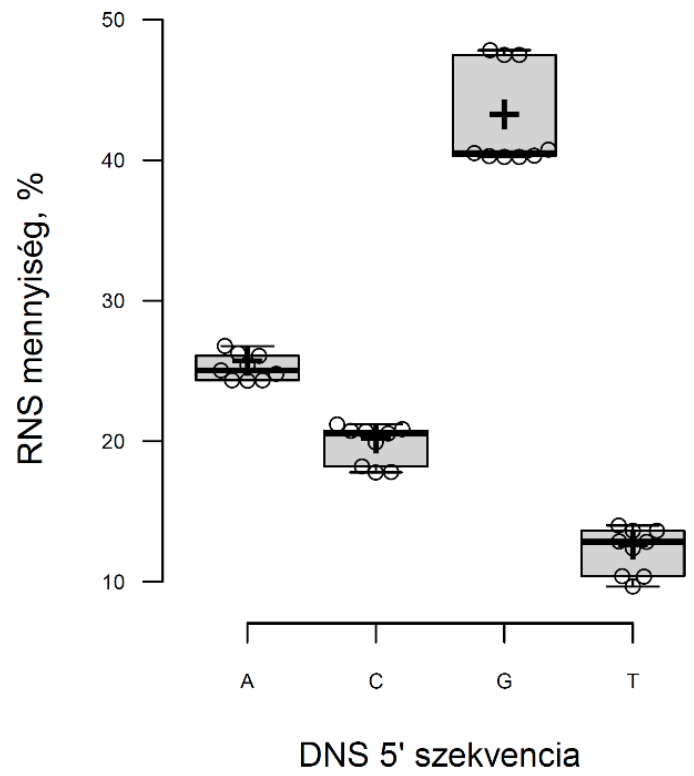

41. Ábra. A +1-es pozícióban lévő nukleotid hatása az RNS expresszióra

Az ábrán a +1-es pozícióban lévő nukleotid hatása látható a T7 promóterről termelődött RNS-ek mennyiségére. Az ábra az összes transzkripciós iniciációs pozíció transzkriptumainak mennyiségeit mutatja. 1 adatpont megadja, hogy adott nukleotiddal az összes RNS hány \%-a keletkezett az adott cDNS könyvtáron belül. A boxokon belüli vastag vízszintes vonalak a mediánokat mutatják; a boxok határolják az R programmal meghatározott 25 . és 75 . percentilist; a szimpla vízszintes vonalak az interkvartilis tartomány 1,5-szereséig terjednek ki a 25 . és 75 . percentilistöl; a keresztek a minták átlagát mutatják; az adatpontok körökként vannak ábrázolva. N=9, amely a 9 cDNS könyvtárnak felel meg. A p értékek a Függelékben a 115. oldalon találhatók meg.

A promótert downstream követő első 2 nukleotidot vizsgálva azt találtuk, hogy a T7 promóternél is rendkívül fontos az átíródott RNS-ek mennyiségére nézve a +2-es pozíció is (42. ábra). Eredményeink alapján a legtöbb RNS GA és meglepő módon AG kezdettel keletkezik. AG és GA szignifikánsan a legjobbak a 16 variáció közül és az ezekről a kezdő szekvenciákról keletkezett RNS-ek mennyisége egymástól szignifikánsan nem különbözik. A GT és a GA is szignifikánsan több RNS-t eredményeztek, mint a GC és a GG. Eredményeink alapján, ha a promóter utáni első két pozíció szekvenciáját vizsgáljuk, nem keletkezik több RNS GG-vel, mint ha a +1 G-t másik nukleotid követi, sőt a GA kezdő szekvenciáról átlagosan mintegy kétszer annyi RNS expresszálódik, mint GG-ről.

A 42. ábrán látható eredményeink alapján keletkezhet a T7 promóterről olyan mennyiségü RNS +1A-val, sőt a +1-es pozícióban pirimidinnel is, mint +1G-vel, és $+1 \mathrm{G}$-vel is különbség van az RNS szintekben a +2-ben elhelyezkedő nukleotidtól függően. 


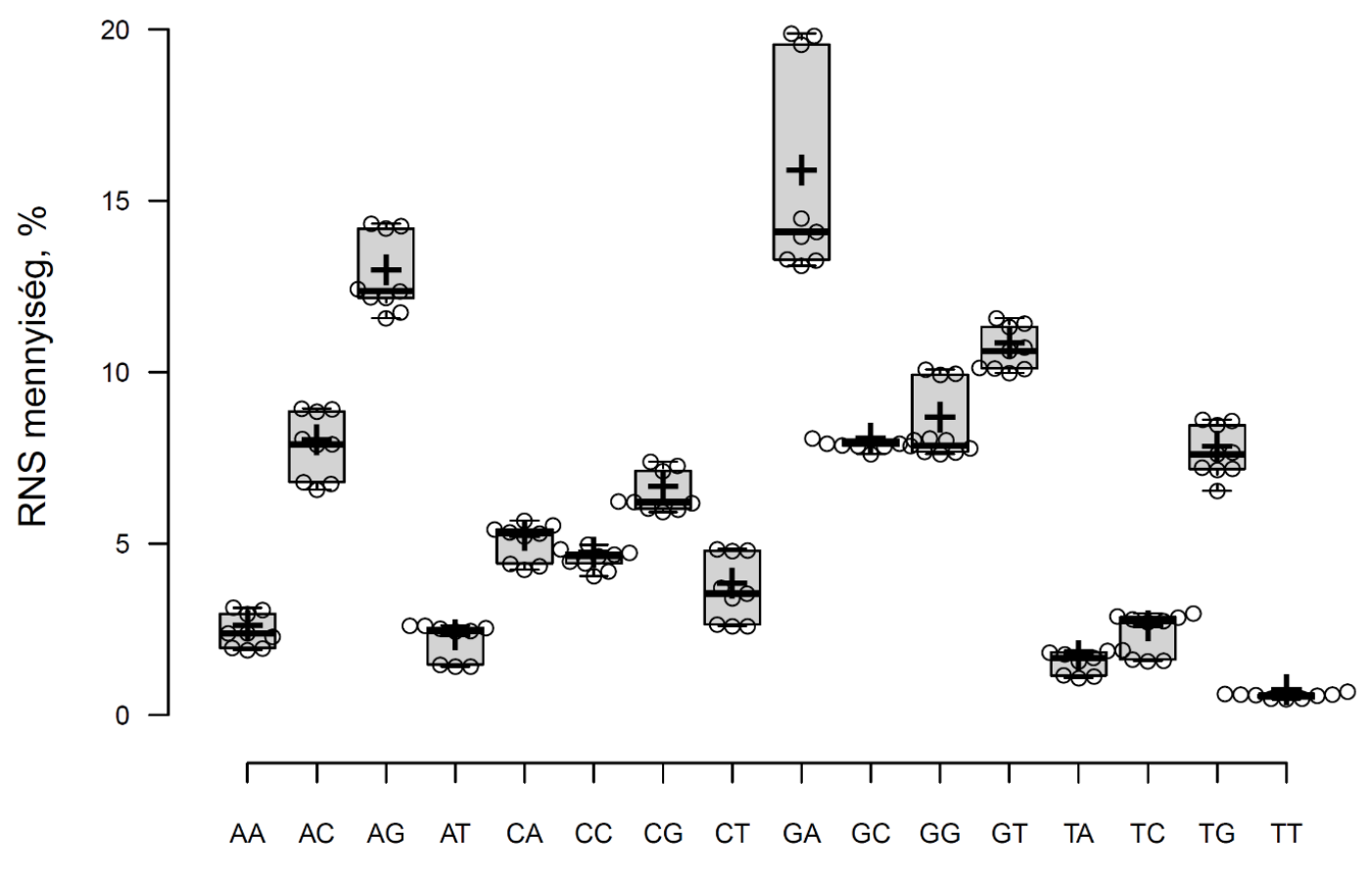

DNS 5' szekvencia

\section{2. Ábra. A promótertől downstream elhelyezkedő első két nukleotid hatása az RNS expresszióra}

Az ábrán a promótert követő első két nukleotid hatása látható a T7 promóterről termelődött RNS-ek mennyiségére. Az ábra az összes transzkripciós iniciációs pozíció transzkriptumainak mennyiségeit mutatja. 1 adatpont megadja az összes szekvenciáról termelődött RNS-ek összegéhez képest keletkezett RNS-ek százalékos arányát az adott szekvenciáról, adott cDNS könyvtáron belül. A boxokon belüli vastag vízszintes vonalak a mediánokat mutatják; a boxok határolják az $\mathrm{R}$ programmal meghatározott 25. és 75 . percentilist; a szimpla vízszintes vonalak az interkvartilis tartomány 1,5-szereséig terjednek ki a 25. és 75. percentilistől; a keresztek a minták átlagát mutatják; az adatpontok körökként vannak ábrázolva. $\mathrm{N}=9$, amely a 9 cDNS könyvtárnak felel meg. A p értékek a Függelékben a 115. oldalon találhatók meg.

Mivel az eddig bemutatott eredményeink alapján, összességében akkor keletkezik a legtöbb RNS, ha a +1-ben G van, és ilyenkor az RNS-ek nagyrészt pontosan a +1-ről íródnak át, ezért a további pozíciók szerepét az RNS mennyiségekre már csak +1 G-vel mutatom be a továbbiakban. Ezek közül az első 3 pozíció szekvenciáját vizsgálva azt találtuk, hogy összességében a GA kezdetű szekvenciák vezettek a legtöbb RNS-hez és a GGG szekvencia a promótertől downstream a legalacsonyabb RNS szintet eredményező +1-ben G-t tartalmazó szekvenciák közé tartozik. Eredményeink alapján a T7 promóternél is fontos szerepet játszik a +3-as pozíció és ez is szignifikáns különbségeket okozhat az RNS mennyiségben (43. ábra). 


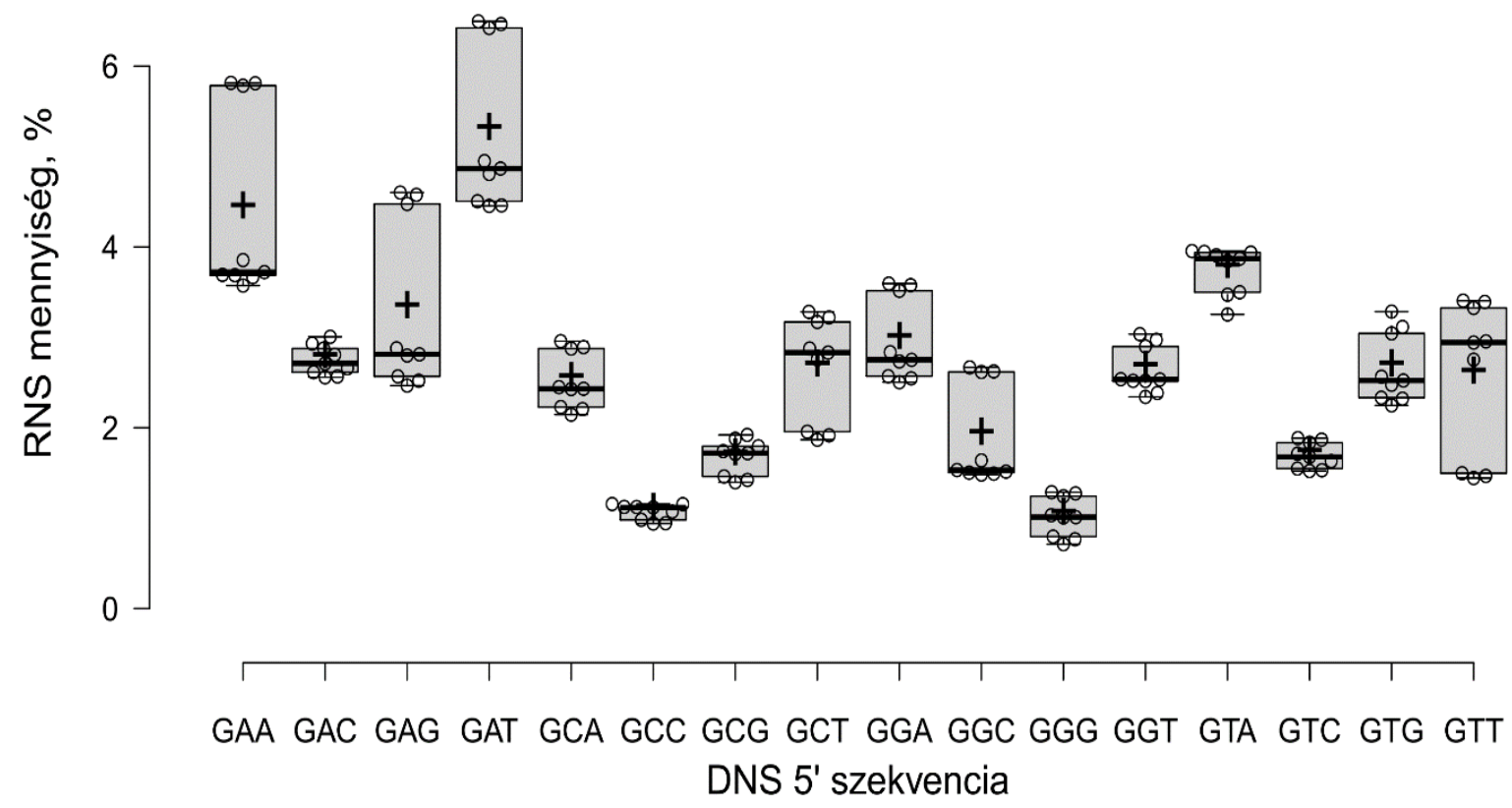

43. Ábra. A +2 és +3 pozíciókban lévő nukleotidok hatása az RNS expresszióra, ha a +1-es pozícióban G van

$\mathrm{Az}$ ábrán a +2 és +3 pozíciókban lévő nukleotidok hatása látható a T7 promóterről termelődött RNS-ek mennyiségére, ha a +1-es pozícióban $G$ van. Az ábra az összes transzkripciós iniciációs szekvencia transzkriptumainak mennyiségeit mutatja. 1 adatpont megadja az adott szekvenciáról keletkezett RNS-ek százalékos arányát az összes szekvenciáról termelődött RNS-ek összegéhez képest az adott cDNS könyvtárban. A boxokon belüli vastag vízszintes vonalak a mediánokat mutatják; a boxok határolják az $\mathrm{R}$ programmal meghatározott 25. és 75. percentilist; a szimpla vízszintes vonalak az interkvartilis tartomány 1,5-szereséig terjednek ki a 25. és 75. percentilistöl; a keresztek a minták átlagát mutatják; az adatpontok körökként vannak ábrázolva. $\mathrm{N}=9$, amely a 9 cDNS könyvtárnak felel meg. A p értékek a Függelékben a 116. oldalon találhatók meg.

A promótertől downstream 4. pozícióban lévő nukleotid hatását a T7 promóterről átíródott transzkriptumok mennyiségére a templátban GG-vel kezdődő szekvenciákkal mutatom be. Azt találtuk, hogy még a 4. pozíció is egyes esetekben okozott szignifikáns különbséget az RNS mennyiségben és a GGGG kezdetü szekvenciáról a GGGC kivételével az összes vizsgált szekvenciához képest szignifikánsan a legkevesebb RNS keletkezett (44. ábra). Eredményünk alapján akár néhányszoros RNS mennyiségbeli különbségeket is képes okozni a 4. pozícióban elhelyezkedő nukleotid, ha az első 3 megegyezik, tehát még a 4. pozícióban lévő nukleotid is befolyásolja a transzkripciót. 


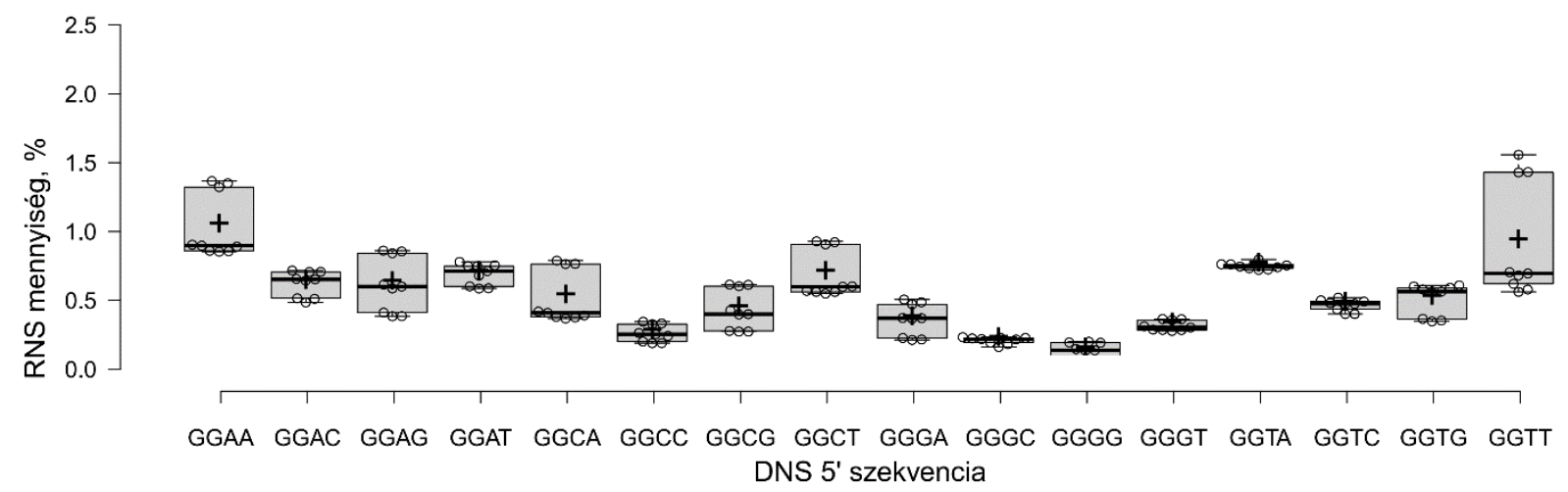

44. Ábra. A +3 és +4 pozíciókban lévő nukleotidok hatása az RNS expresszióra, ha a promótertől downstream elhelyezkedő első két nukleotid GG

Az ábrán a +3 és +4 pozíciókban lévő nukleotidok hatása látható a T7 promóterről termelődött RNS-ek mennyiségére, ha a promótertől downstream elhelyezkedő első két nukleotid GG. Az ábra az összes transzkripciós iniciációs pozíció transzkriptumainak mennyiségeit mutatja. 1 adatpont megadja az adott szekvenciáról keletkezett RNS-ek százalékos arányát az összes szekvenciáról termelődött RNS-ek összegéhez képest az adott cDNS könyvtárban. A boxokon belüli vastag vízszintes vonalak a mediánokat mutatják; a boxok határolják az $\mathrm{R}$ programmal meghatározott 25. és 75. percentilist; a szimpla vízszintes vonalak az interkvartilis tartomány 1,5szereséig terjednek ki a 25. és 75. percentilistöl; a keresztek a minták átlagát mutatják; az adatpontok körökként vannak ábrázolva. $\mathrm{N}=9$, amely a 9 cDNS könyvtárnak felel meg. A p értékek a Függelékben a 116. oldalon találhatók meg.

A promótertől downstream elhelyezkedő első 4 bázispár hosszú szekvencia függvényében a fenti eredmények alapján látható módon változó mennyiségü RNS expresszálódik a T7 promóterről. A legkisebb és a legnagyobb expressziót biztosító szekvenciákról termelődött RNS mennyiségek átlagai között közel 50x-es különbség van +1A-val (AAAC és AGAA), közel 5x-ös AG kezdettel (AGGG és AGAA) és több, mint 13x-os +1G-vel (GGGG és GATA) (45. ábra). A 45. ábrán látható, hogy a legnagyobb expressziót biztosító 4 bázispáros szekvenciák +1A-val a 2. pozícióban G-t vagy C-t tartalmaznak. 
45. Ábra. A T7 promótertől downstream elhelyezkedő négy bázisos szekvencia hatása az RNS expresszióra, ha a +1 A vagy $G$

Az ábrán a +1-től a +4-es pozícióig terjedő szekvencia hatása látható a T7 promóterről termelődött RNS-ek mennyiségére, ha az első pozícióban $A$ vagy $G$ van. Az ábra az összes transzkripciós iniciációs pozíció transzkriptumainak mennyiségeit mutatja. 1 oszlop megadja, hogy az összes lehetséges szekvenciáról (256 variáció) termelődött RNS-ek összegéhez képest adott szekvenciáról az RNS-ek hány \%-a keletkezett átlagosan. A hibasávok a százalékos értékek átlagainak szórását mutatják. N=9, amely a 9 cDNS könyvtárnak felel meg.

\subsubsection{Az U6T7 promóter}

Az U6T7 hibrid promótert Romanienko és mtsai +1G-vel javasolták alkalmazni ${ }^{57}$. Annak ismeretében, hogy a +1 -es pozíció más promótereknél befolyásolja a transzkripciós kezdő pozíciót, valamint az RNS expressziót, ezért ezt a promótert is alaposabban megvizsgáltuk. Az NGS eredményeink alapján először megnéztük a +1-es pozíció szerepét a transzkripciós iniciációs pozíciókra. Míg az összes általunk vizsgált promóternél a purinokról, vagy legalább a guaninról majdnem 100\%-ban a +1-ről indul el az átírás, azt találtuk, hogy az U6T7 promóternél sokkal heterogénebb a transzkripció iniciáció pozíciója (46. ábra). Az U6T7 promóterről az összes általunk vizsgált promóterhez képest sokkal nagyobb arányban indul el az átírás a -1-röl, még guaninnal is átlag 30\%-ban. Ha a +1-ben A volt, akkor az összes RNS átlag 36\%-a keletkezett a +1 pozícióról, $+1 \mathrm{G}$-vel is csak 59\%. Rendkívül kis arányban indul el pontosan az átírás, ha a +1 pirimidin, a purinokhoz képest. $+1 \mathrm{C}$-vel $7 \%,+1 \mathrm{~T}$-vel $11 \%$ volt a +1-ről átíródott RNS-ek aránya. 
A

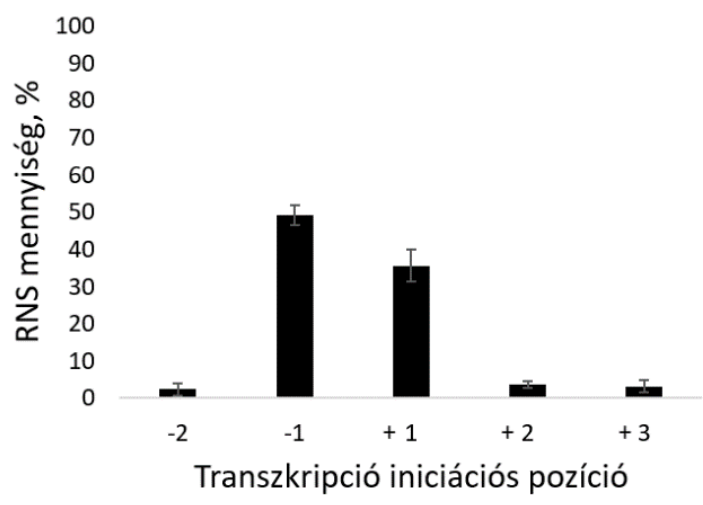

G

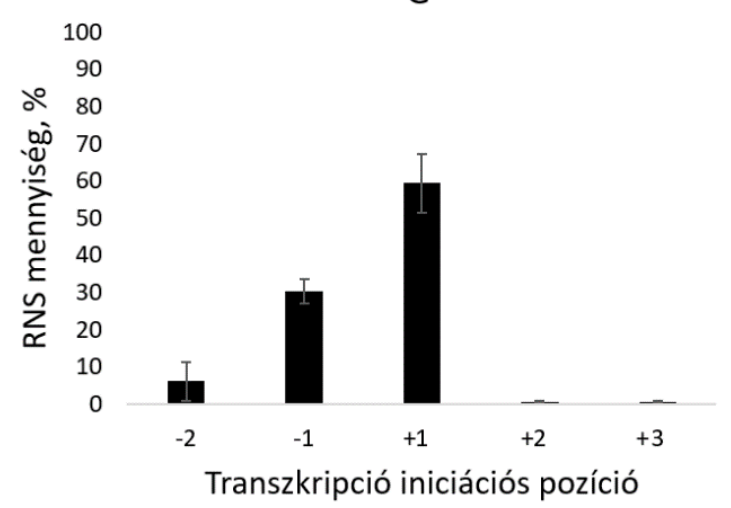

C

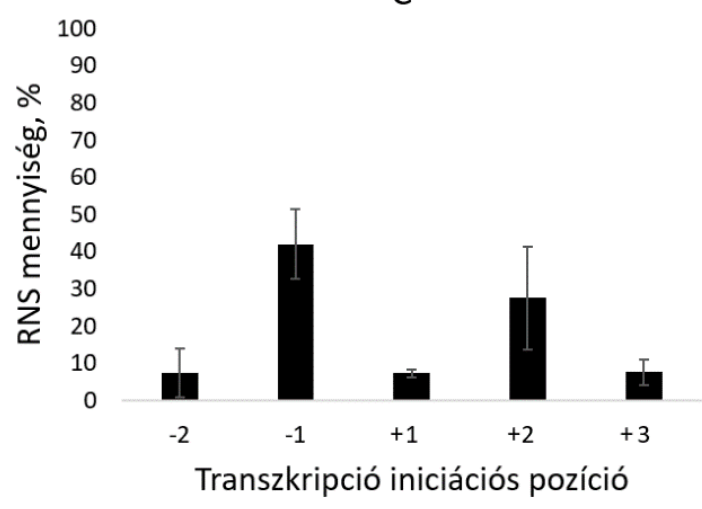

$\mathrm{T}$

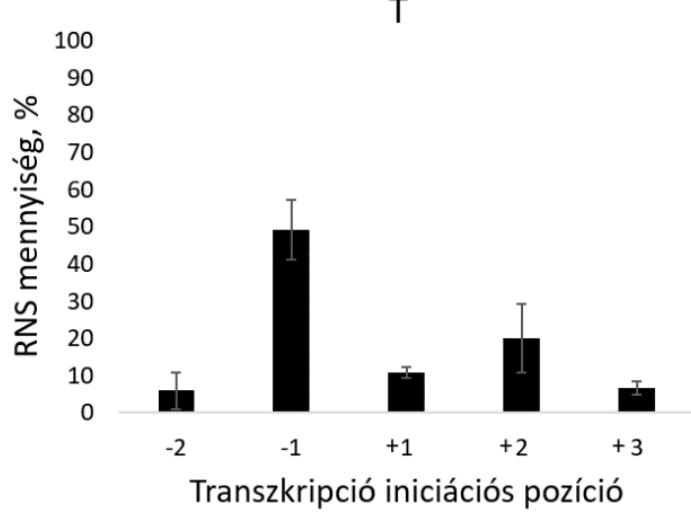

46. Ábra. A +1-es pozícióban lévő nukleotid hatása a különböző transzkripció iniciációs pozíciókra

Az ábrán látható, hogy az U6T7 promótertől downstream elhelyezkedő első nukleotid miképp befolyásolja, hogy melyik pozícióról milyen arányban indul el az átírás. Egy oszlop megmutatja, hogy az összes vizsgált pozícióról termelődött RNS-ek összegének átlagban hány \%-a íródott át adott pozícióról. A hibasávok a százalékos értékek átlagainak szórását mutatják. $\mathrm{N}=9$, amely a $9 \mathrm{cDNS}$ könyvtárnak felel meg.

Ezután megvizsgáltuk a további pozíciókban lévő nukleotidok szerepét is a különböző transzkripciós kezdő pozíciókra. A 47. ábra alapján látható, hogy a további pozícióknak ennél a promóternél is szerepe van a transzkripciós iniciáció pozíciójának meghatározásában. +1Gvel indul el a legnagyobb arányban +1-ről az átírás, de a többi promóterhez képest ezt a +3-4es pozíciók is jobban befolyásolják. +1A-ról, ha a +2 A, szinte alig keletkezik RNS a +1-es pozícióról, míg ha a $+2 \mathrm{G}$, akkor a legtöbb (ha csak az első két pozíciót tekintjük) és a további pozíciók is befolyásolják, hogy milyen arányban indul el +1-ről az átírás (47. ábra). 


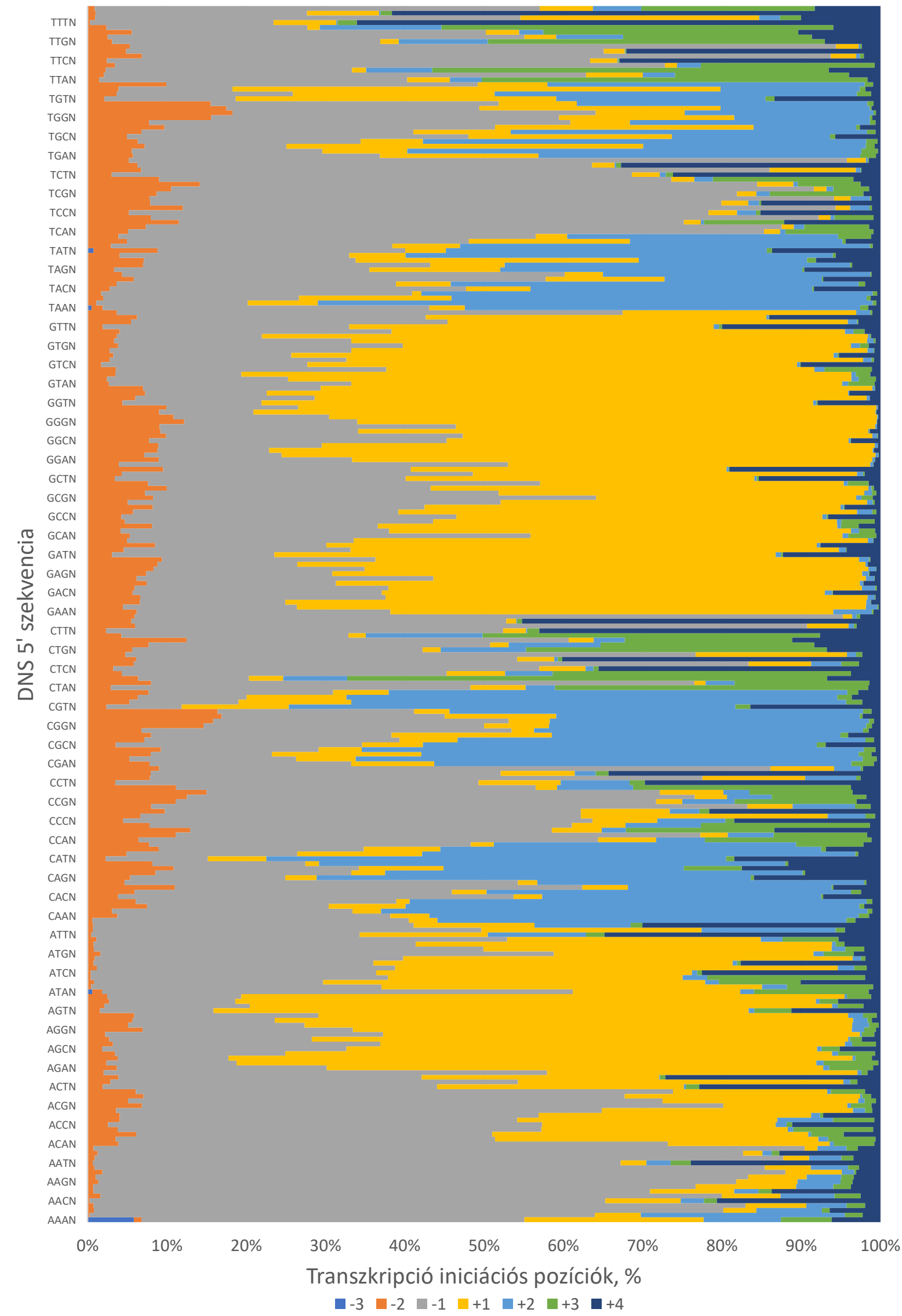




\section{7. Ábra. Az U6T7 promótertől downstream elhelyezkedő szekvenciák hatása a különböző transzkripció iniciációs pozíciókra}

Az ábrán látható, hogy az U6T7 promótertől downstream elhelyezkedő szekvenciák miképp befolyásolják, hogy melyik pozícióról milyen arányban indul el az átírás. Egy oszlop egy színe megmutatja, hogy az összes vizsgált pozícióról termelődött RNS-ek összegének átlagban hány \%-a íródott át adott pozícióról, és egy oszlop egy darab kezdő szekvenciát jelöl. A közepesen világoskék szín a -3, a narancssárga szín a -2, a szürke szín a -1, a citromsárga szín a +1 , a világoskék szín a +2 , a zöld szín a +3 és a sötétkék szín a +4 pozíciókat jelöli az U6T7 promótertől downstream. $\mathrm{N}=9$, amely a 9 cDNS könyvtárnak felel meg.

Ha a +1-ben pirimidin van csak elvétve a +1 a transzkripció kezdő pozíciója. Ha a +1 -es pozícióban pirimidin van, a +2-ben purin, akkor nagyobb arányban indul el a +2-röl, vagy a 1-ről a transzkripció, mint a +1-ről. Ha a promótertől downstream elhelyezkedő első 2 pozícióban pirimidin van, de a harmadikban purin, szintén megfigyelhető, hogy megnő azoknak az RNS-eknek az aránya, amelyek a -1-es kezdő pozícióról keletkeztek (47. ábra). Eredményeink azt mutatják, hogy ha az U6T7 promóternél a +1-ben purin van, az átírás a többi vizsgált promóterrel szemben akkor sem csak a +1-ről indul el, míg ha a +1 pirimidin, az átírás nagyon ritkán történik+1-röl, és azt, hogy melyik pozícióról milyen arányban történik a transzkripció iniciációja, nagymértékben befolyásolják a promótertől downstream elhelyezkedő további nukleotidok is.

A következő lépésekben azt néztük meg, hogy az U6T7 promótertől downstream elhelyezkedő pozíciók hogyan hatnak a transzkriptumok mennyiségére (48. ábra). Az első nukleotid szerepét vizsgálva az átíródott RNS-ek mennyiségére azt találtuk, hogy nincsenek olyan nagy különbségek, mint a T7, U6, 7sk promótereknél. A +1C-röl szignifikánsan kevesebb RNS keletkezett, mint a többiről. A és T között nem találtunk szignifikáns különbséget, a $\mathrm{G}$ pedig mindegyiknél szignifikánsan több RNS-t eredményezett 


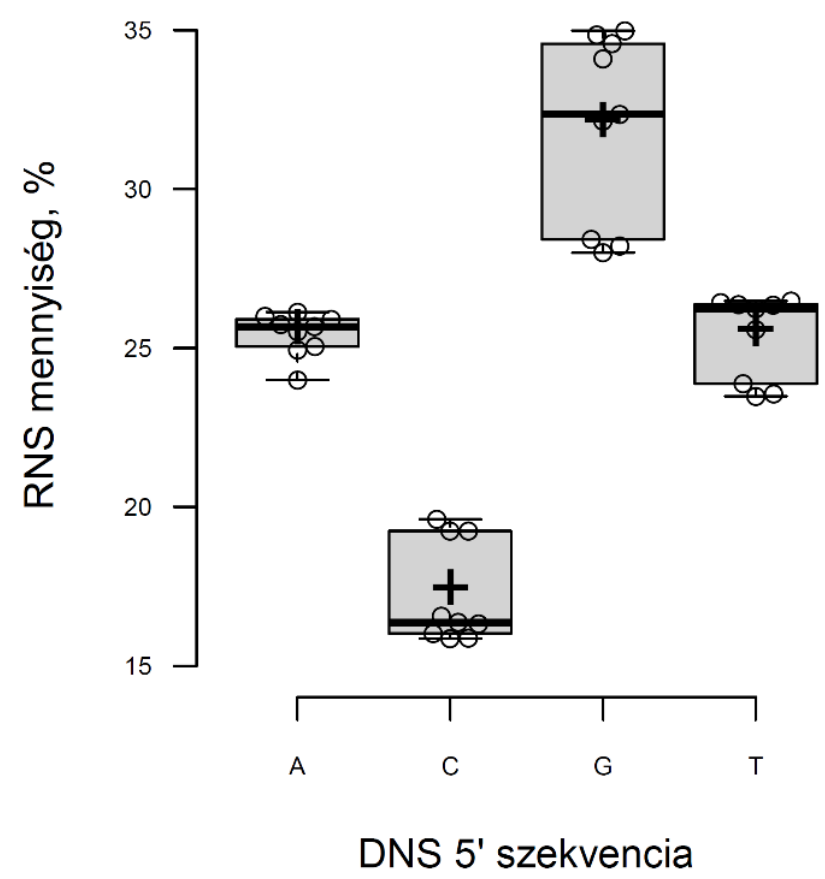

48. Ábra. A +1-es pozícióban lévő nukleotid hatása az RNS expresszióra

Az ábrán a +1-es pozícióban lévő nukleotid hatása látható az U6T7 promóterről termelődött RNS-ek mennyiségére. Az ábra az összes transzkripciós iniciációs pozíció transzkriptumainak mennyiségeit mutatja. 1 adatpont megadja, hogy adott nukleotiddal az összes RNS hány \%-a keletkezett az adott cDNS könyvtáron belül. A boxokon belüli vastag vízszintes vonalak a mediánokat mutatják; a boxok határolják az $\mathrm{R}$ programmal meghatározott 25. és 75. percentilist; a szimpla vízszintes vonalak az interkvartilis tartomány 1,5-szereséig terjednek ki a 25. és 75. percentilistől; a keresztek a minták átlagát mutatják; az adatpontok körökként vannak ábrázolva. $\mathrm{N}=9$, amely a 9 cDNS könyvtárnak felel meg. A p értékek a Függelékben a 117. oldalon találhatók meg.

A promótert downstream követő első 2 pozíciót vizsgálva, azt kaptuk, hogy ennél a promóternél is befolyásolja a +2 is a promóterről keletkezett RNS-ek mennyiségét (49. ábra). Eredményeink alapján ennél a promóternél is keletkezhet olyan mennyiségü RNS a +1-es pozícióban pirimidinnel, mint purinnal, ha megfelelő nukleotid követi. Amiatt, hogy nem elég pontos a +1ről történő átírás még akkor sem, ha a +1-ben purin van, az U6T7 promóterrel kapcsolatos további eredmények nem kerülnek bemutatásra. 


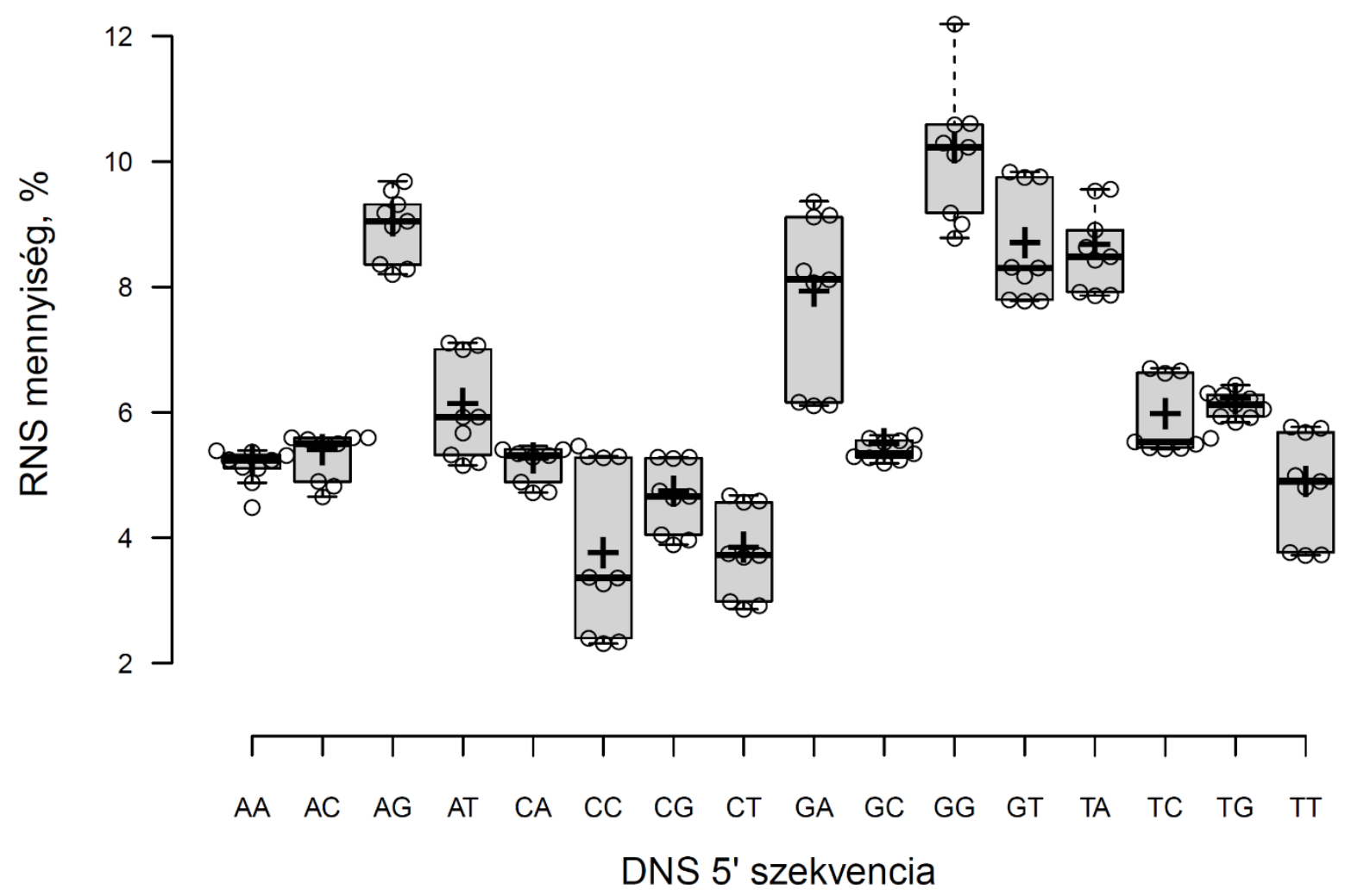

49. Ábra. A promótertől downstream elhelyezkedő első két nukleotid hatása az RNS expresszióra

Az ábrán a promótert követő első két nukleotid hatása látható az U6T7 promóterről termelődött RNS-ek mennyiségére. Az ábra az összes transzkripciós iniciációs pozíció transzkriptumainak mennyiségeit mutatja. 1 adatpont megadja az összes szekvenciáról termelödött RNS-ek összegéhez képest keletkezett RNS-ek százalékos arányát az adott szekvenciáról, adott cDNS könyvtáron belül. A boxokon belüli vastag vízszintes vonalak a mediánokat mutatják; a boxok határolják az $\mathrm{R}$ programmal meghatározott 25 . és 75 . percentilist; a szimpla vízszintes vonalak az interkvartilis tartomány 1,5-szereséig terjednek ki a 25. és 75. percentilistől; a keresztek a minták átlagát mutatják; az adatpontok körökként vannak ábrázolva. N=9, amely a 9 cDNS könyvtárnak felel meg. A p értékek a Függelékben a 117. oldalon találhatók meg.

\subsubsection{A J23119 promóter}

A J23119 promóterről eddig nem ismert, hogy a promótertől downstream elhelyezkedő nukleotidok befolyásolják-e a transzkripció iniciációjának pontos helyét. Az NGS eredményeink alapján először megvizsgáltuk +1 -es pozíció szerepét a transzkripciós iniciációs kezdő pozíciókra (50. ábra). Ha a +1-ben A volt, akkor az összes RNS átlag 86\%-a keletkezett a +1 pozícióról, +1 G-vel pedig $89 \%$. Habár a purinokhoz képest kisebb arányban indul el pontosan az átírás, ha $\mathrm{a}+1$ pirimidin, de a többi vizsgált promóterhez képest több a +1 -böl átíródó RNS pirimidinekről is. +1C-vel 42\%, +1T-vel $65 \%$ volt a +1-ről átíródott RNS-ek aránya. 


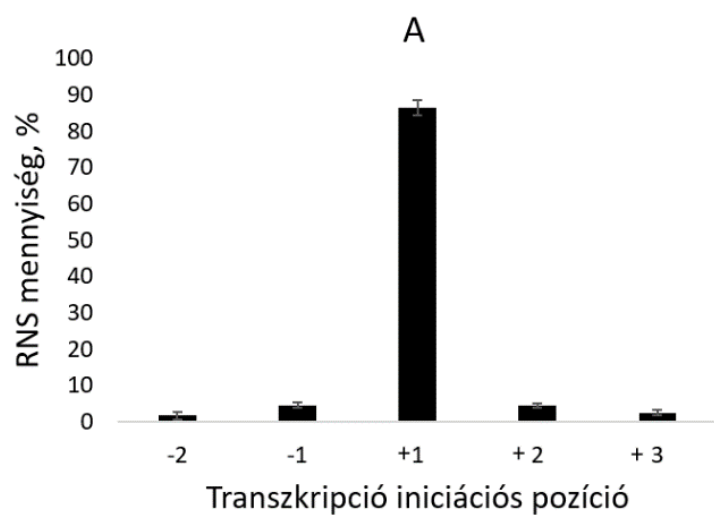

G

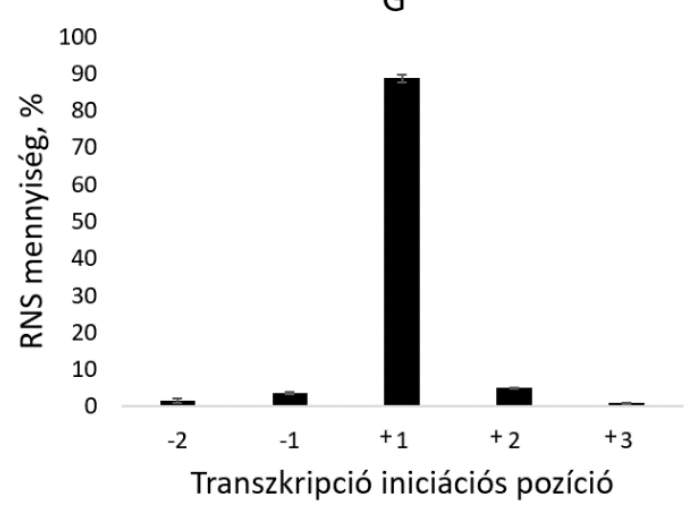

C

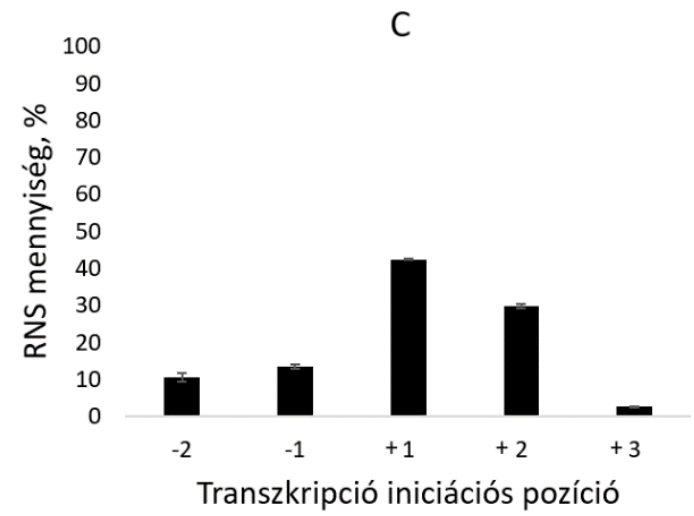

T

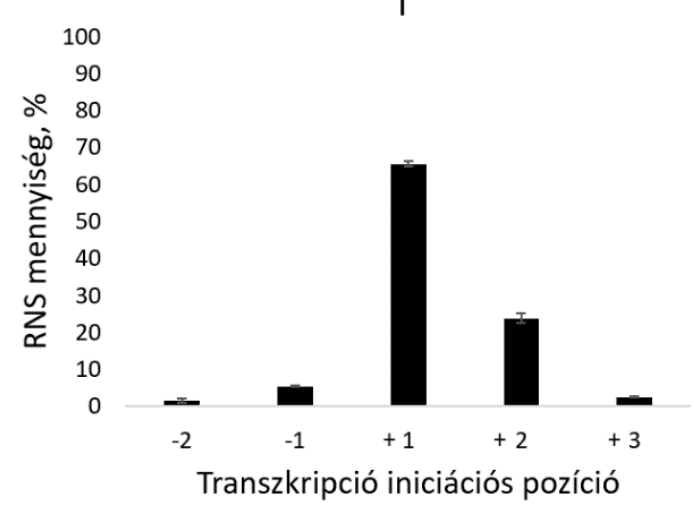

50. Ábra. A J23119 promótertől downstream elhelyezkedő első nukleotid hatása a különböző transzkripció iniciációs pozíciókra

Az ábrán látható, hogy a J23119 promótertől downstream elhelyezkedő első nukleotid miképp befolyásolja, hogy melyik pozícióról milyen arányban indul el az átírás. Egy oszlop megmutatja, hogy az összes vizsgált pozícióról termelődött RNS-ek összegének átlagban hány \%-a íródott át adott pozícióról. A hibasávok a százalékos értékek átlagainak szórását mutatják. $\mathrm{N}=3$, amely a 3 cDNS könyvtárnak felel meg.

Ezután megvizsgáltuk a további pozíciókban lévő nukleotidok szerepét is a különböző transzkripciós kezdő pozíciókra. Eredményeink azt mutatják, hogy ha a +1 -es pozícióban purin van, az átírás majdnem mindig a +1-ről indul el, míg ha pirimidin, az átírás nemcsak +1-ről történik. Azt, hogy pirimidin esetében melyik pozícóiról milyen arányban történik a transzkripció iniciációja, befolyásolják a promótertől downstream elhelyezkedő további nukleotidok is. Azt találtuk, hogy vannak olyan pirimidin kezdetű szekvenciák, amelyeknél megközelíti a +1-es pozícióból átíródó RNS-ek aránya a purin kezdetűekét, ilyenek a CT, TC, TT kezdetű szekvenciák. Ha a +1-ben pirimidin van, és a +2-ben purin, akkor nagyobb arányban indul el a +2-ről a transzkripció, mint a +1-ről (51. ábra). 


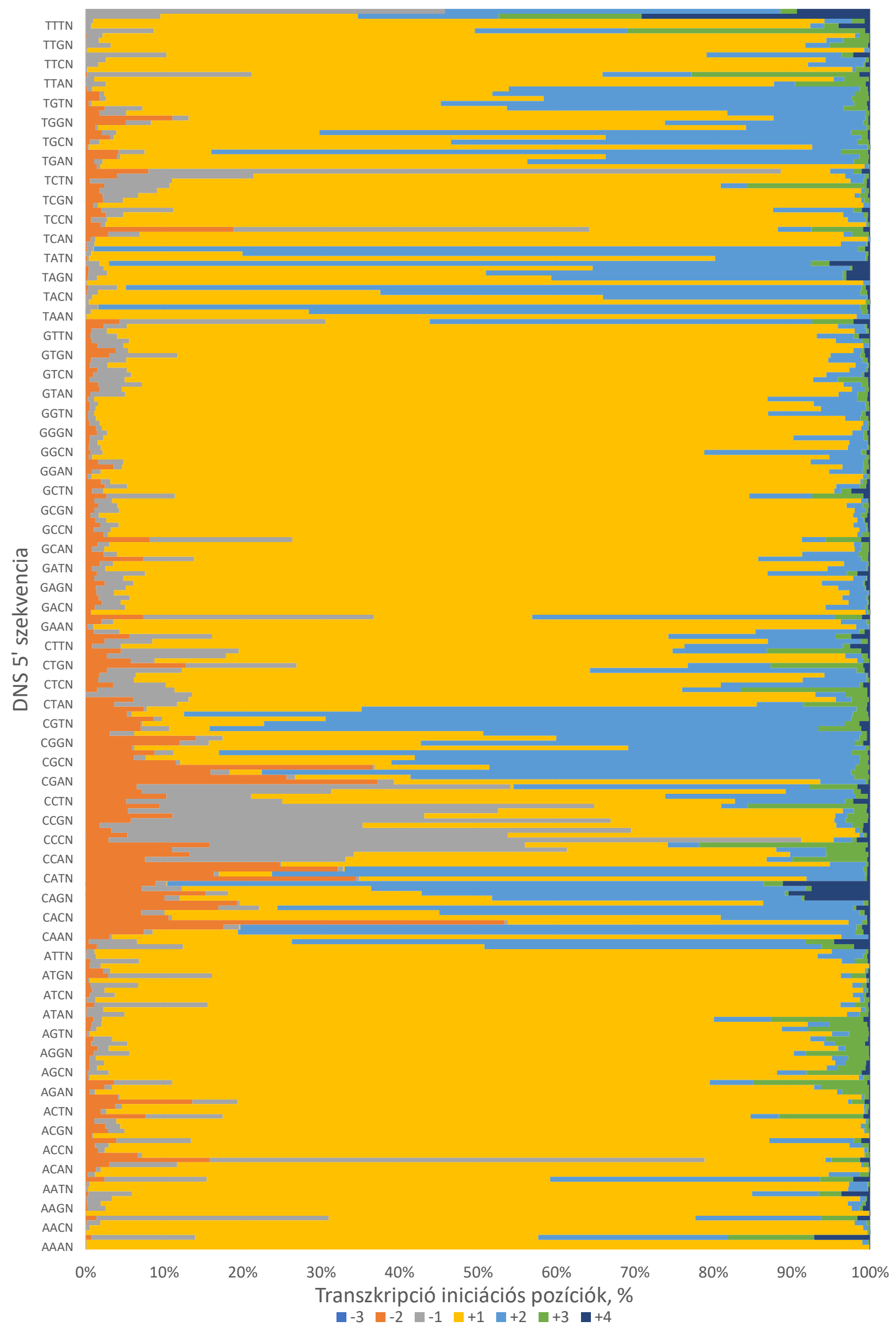


51. Ábra. A J23119 promótertől downstream elhelyezkedő szekvenciák hatása a különböző transzkripció iniciációs pozíciókra

Az ábrán látható, hogy a J23119 promótertől downstream elhelyezkedő szekvenciák miképp befolyásolják, hogy melyik pozícióról milyen arányban indul el az átírás. Egy oszlop egy színe megmutatja, hogy az összes vizsgált pozícióról termelődött RNS-ek összegének átlagban hány \%-a íródott át adott pozícióról, és egy oszlop egy darab kezdő szekvenciát jelöl. A közepesen világoskék szín a -3, a narancssárga szín a -2, a szürke szín a -1, a citromsárga szín a +1 , a világoskék szín a +2 , a zöld szín a +3 és a sötétkék szín a +4 pozíciókat jelöli a J23119 promótertől downstream. $\mathrm{N}=3$, amely a 3 cDNS könyvtárnak felel meg.

Eredményeink alapján, ha az első pozícióban purin van, szinte csak jó hosszúságú RNS-ek keletkeznek, majdnem mindig a +1-es pozícióról kezdődik az átírás. Viszont van néhány szekvencia, +1A-ról kicsit több, mint +1G-ről, amelyiknél drasztikusan kevesebb jó hosszúságú RNS keletkezett (52. ábra). Azonban összességében nincs jelentős eltérés a +1 -es pozícióban A és G között abban, hogy milyen pontos a transzkripció iniciációja.
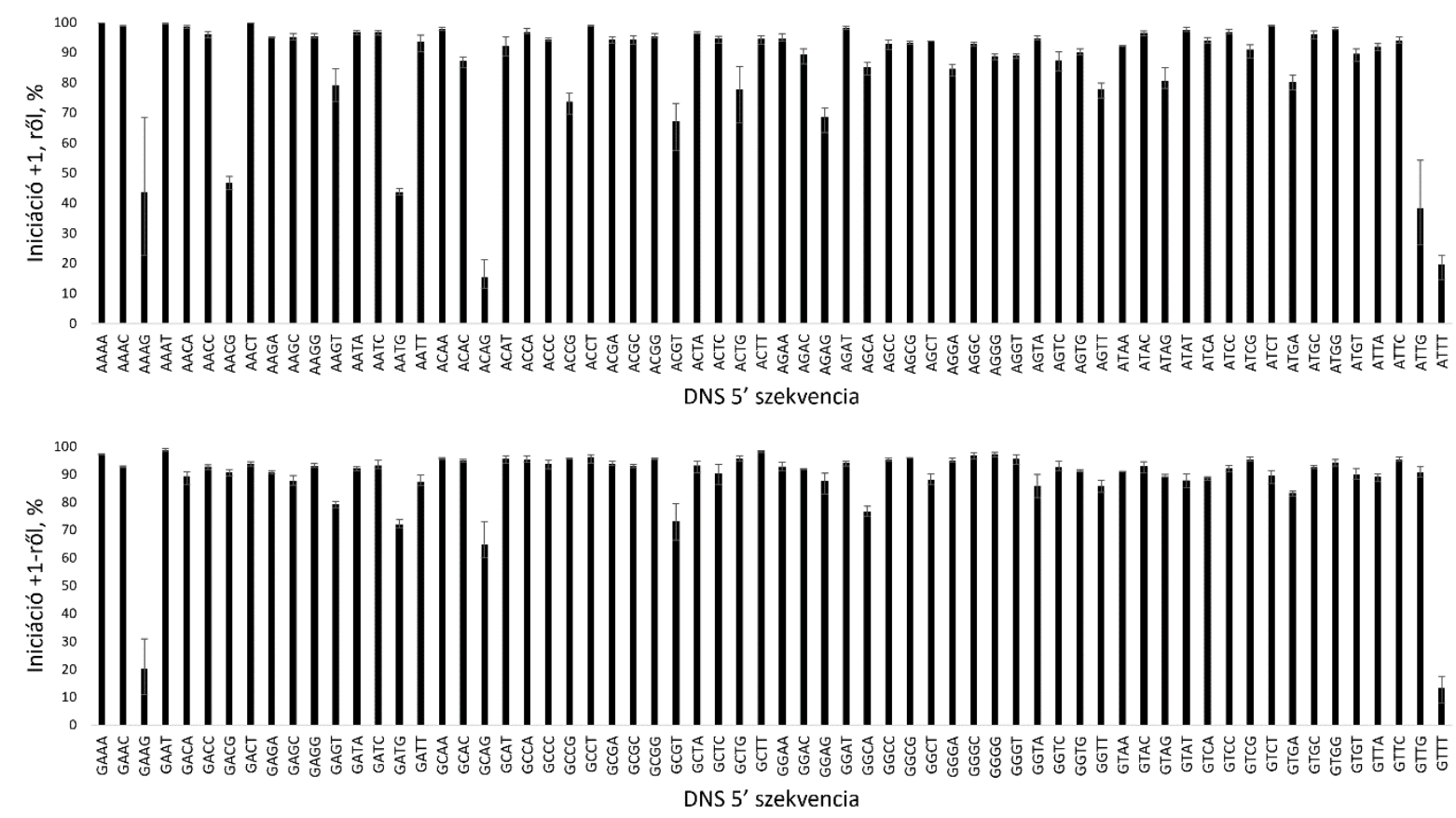

52. Ábra. A J23119 promótertől downstream lévő szekvenciák hatása a +1-rôl induló transzkripcióra, ha a +1 A, vagy $G$

Az ábrán a J23119 promóter után elhelyezkedő különböző szekvenciák szerepe látható a +1 pozícióról történő átírásra. Az oszlopok megmutatják, hogy átlagban hány \%-ban indult el +1-ről az átírás adott templát DNS szekvencia esetén. A hibasávok a százalékos értékek átlagainak szórását mutatják. $\mathrm{N}=3$, amely a $3 \mathrm{cDNS}$ könyvtárnak felel meg. 
A következő lépésekben azt vizsgáltuk meg, hogy a J23119 promótertől downstream elhelyezkedő nukleotidok hogyan hatnak a transzkriptumok mennyiségére. Az +1 -es pozíció szerepét vizsgálva az átíródott RNS-ek mennyiségére azt találtuk, hogy ha abban a bázis purin, több RNS termelődik, mintha az pirimidin lenne (53. ábra). A +1-ben purinokról keletkezett transzkriptumok mennyisége egymástól szignifikánsan nem különbözik. Ennél a promóternél a $+1 \mathrm{~T}$ is megközelíti a purinok szintjét a róla termelődő RNS-ek mennyiségében, és a +1C-ről is körülbelül 2/3-annyi RNS jött létre, mint bármelyik purinról.

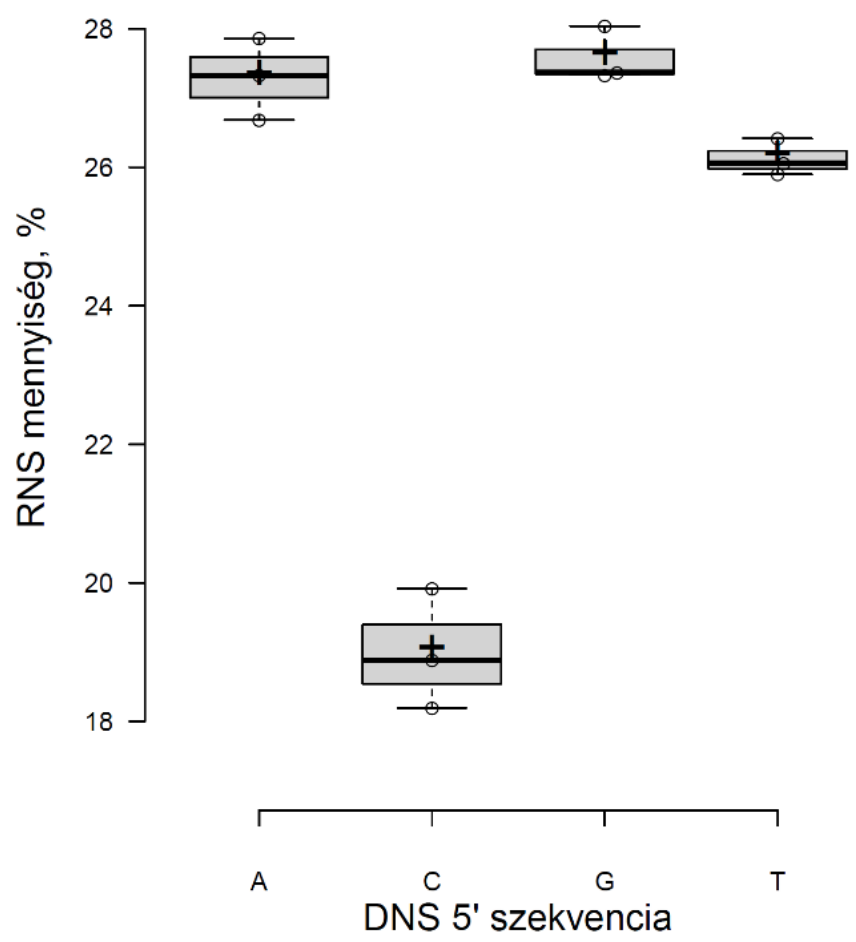

\section{3. Ábra. A +1-es pozícióban lévő nukleotid hatása az RNS expresszióra}

Az ábrán a +1-es pozícióban lévő nukleotid hatása látható a J23119 promóterről termelődött RNS-ek mennyiségére. Az ábra az összes transzkripciós iniciációs pozíció transzkriptumainak mennyiségeit mutatja. 1 adatpont megadja, hogy adott nukleotiddal az összes RNS hány \%-a keletkezett az adott cDNS könyvtáron belül. A boxokon belüli vastag vízszintes vonalak a mediánokat mutatják; a boxok határolják az $\mathrm{R}$ programmal meghatározott 25. és 75. percentilist; a szimpla vízszintes vonalak az interkvartilis tartomány 1,5-szereséig terjednek ki a 25. és 75. percentilistöl; a keresztek a minták átlagát mutatják; az adatpontok körökként vannak ábrázolva. $\mathrm{N}=3$, amely a 3 cDNS könyvtárnak felel meg. A p értékek a Függelékben a 118. oldalon találhatók meg.

A promótertől downstream lévő első 2 pozíciót vizsgálva azt kaptuk, hogy erről a promóterről keletkezett RNS-ek mennyiségében szintén nagyon nagy szerepet játszik a 2. pozíció is (54. ábra). Szignifikánsan a legtöbb RNS AG kezdetű szekvenciákról jött létre, amiről akár több, mint 3x annyi RNS is keletkezhet, mint a többi +1-ben purint tartalmazó kezdő dinukleotidról. Ezt követően a legtöbb RNS, közel azonos mennyiségekkel akkor keletkezett, ha a promótert AA, GA, GG, TA, vagy TG követte. 
Eredményeinkböl látszik, hogy +1A-val sokkal nagyobb különbségek vannak a +2-es pozíció függvényében, és $+1 \mathrm{G}$ és $+1 \mathrm{~T}$ után nagyon hasonló RNS-szintbeli változásokat okoznak a +2es pozícióban lévő eltérő nukleotidok. Ha a $+1 \mathrm{G}$, vagy $\mathrm{T}$, akkor átlagosan kb. 1,5x annyi RNS keletkezett, ha a +2-es pozíció bázisa purin, mint ha pirimidin. Az 54. ábra eredményei alapján keletkezhet olyan mennyiségü RNS a +1 -es pozícióban pirimidinnel is, mint purinnal, ha megfelelő nukleotid követi, valamint a +1A-val, vagy +1G-vel keletkezett RNS-ek mennyiségében is lehet jelentős eltérés, ha a +2-ben különböző nukleotidok szerepelnek.

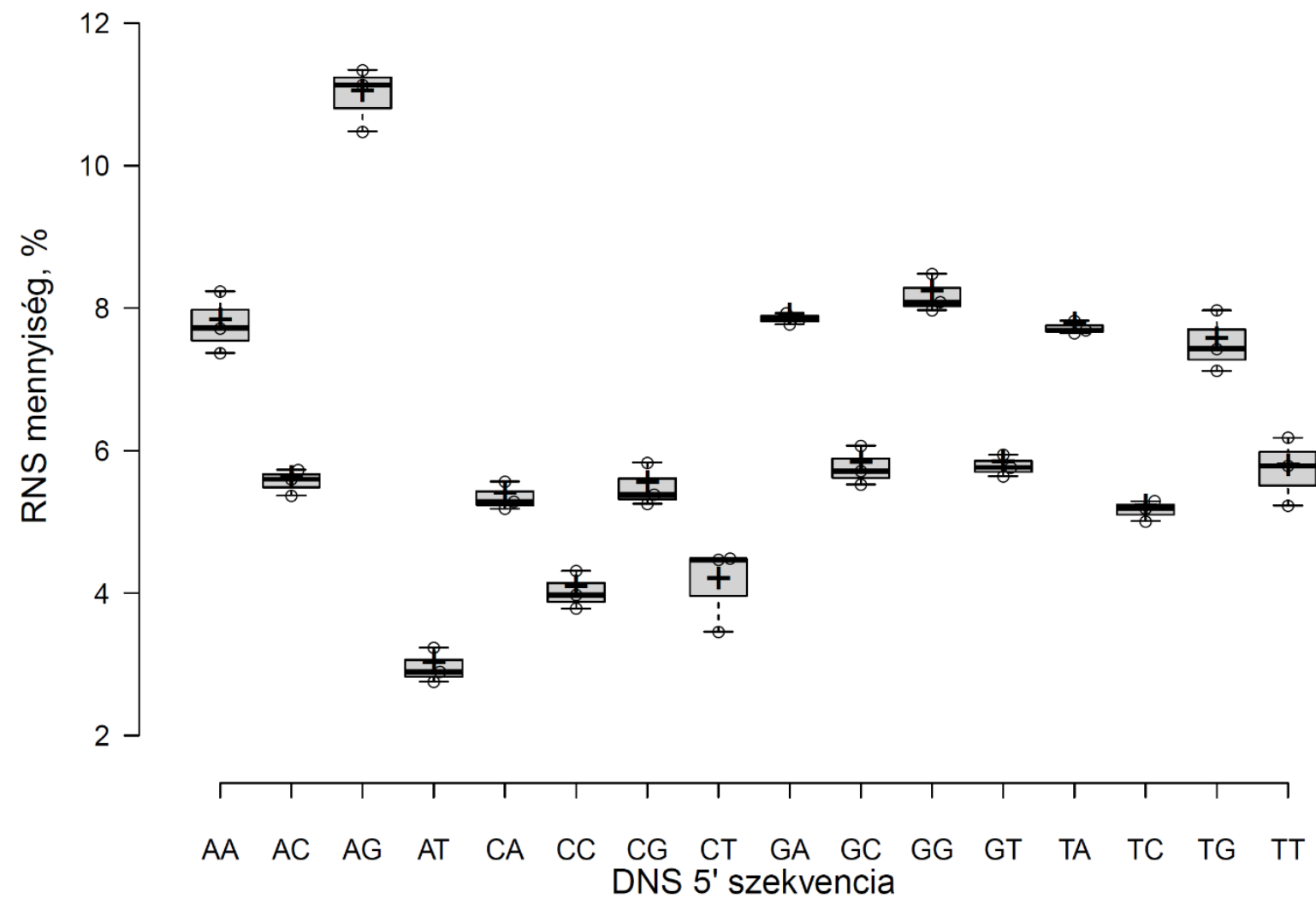

\section{4. Ábra. A promótertől downstream elhelyezkedő első két nukleotid hatása az RNS expresszióra}

Az ábrán a promótert dowsntream követő első két nukleotid hatása látható a J23119 promóterről termelődött RNSek mennyiségére. Az ábra az összes transzkripciós iniciációs pozíció transzkriptumainak mennyiségeit mutatja. 1 adatpont megadja az összes szekvenciáról termelődött RNS-ek összegéhez képest keletkezett RNS-ek százalékos arányát az adott szekvenciáról, adott cDNS könyvtáron belül. A boxokon belüli vastag vízszintes vonalak a mediánokat mutatják; a boxok határolják az R programmal meghatározott 25 . és 75 . percentilist; a szimpla vízszintes vonalak az interkvartilis tartomány 1,5 -szereséig terjednek ki a 25 . és 75 . percentilistől; a keresztek a minták átlagát mutatják; az adatpontok körökként vannak ábrázolva. N=3, amely a 3 cDNS könyvtárnak felel meg. A p értékek a Függelékben a 118. oldalon találhatók meg.

Mivel a transzkripció iniciációjának pozíciója a purinnal kezdődő szekvenciáknál volt legnagyobb arányban a +1 , így a további pozíciók szerepe a disszertáció keretében már csak ezekkel kerül bemutatásra. Az 55. ábrán látható, hogy a +3 és +4 pozíciók is rendkívül fontosak a promóterről expresszálódó RNS-ek mennyiségének meghatározásában. 
Ha a +1-től +2-ig terjedő pozíciók dinukleotidja megegyezik, viszont az azt követő nukleotid nem, az is szignifikáns különbségeket képes okozni az RNS mennyiségekben, viszont ennek mértéke függ attól, hogy a +1 és +2 pozíciókban milyen szekvencia van. Akár néhányszoros RNS mennyiségbeli különbségeket is képes okozni a +4-es pozícióban elhelyezkedő bázis, ha tőle upstream az első 3 megegyezik, tehát még a +4-es pozícióban lévő nukleotid is befolyásolja a transzkripciót. Az 55. ábrán látható, hogy a +3 és a +4 pozíció nem egyforma módon befolyásolja a transzkriptum mennyiségét, hanem a tőle upstream lévő szekvencia függvényében változóan.

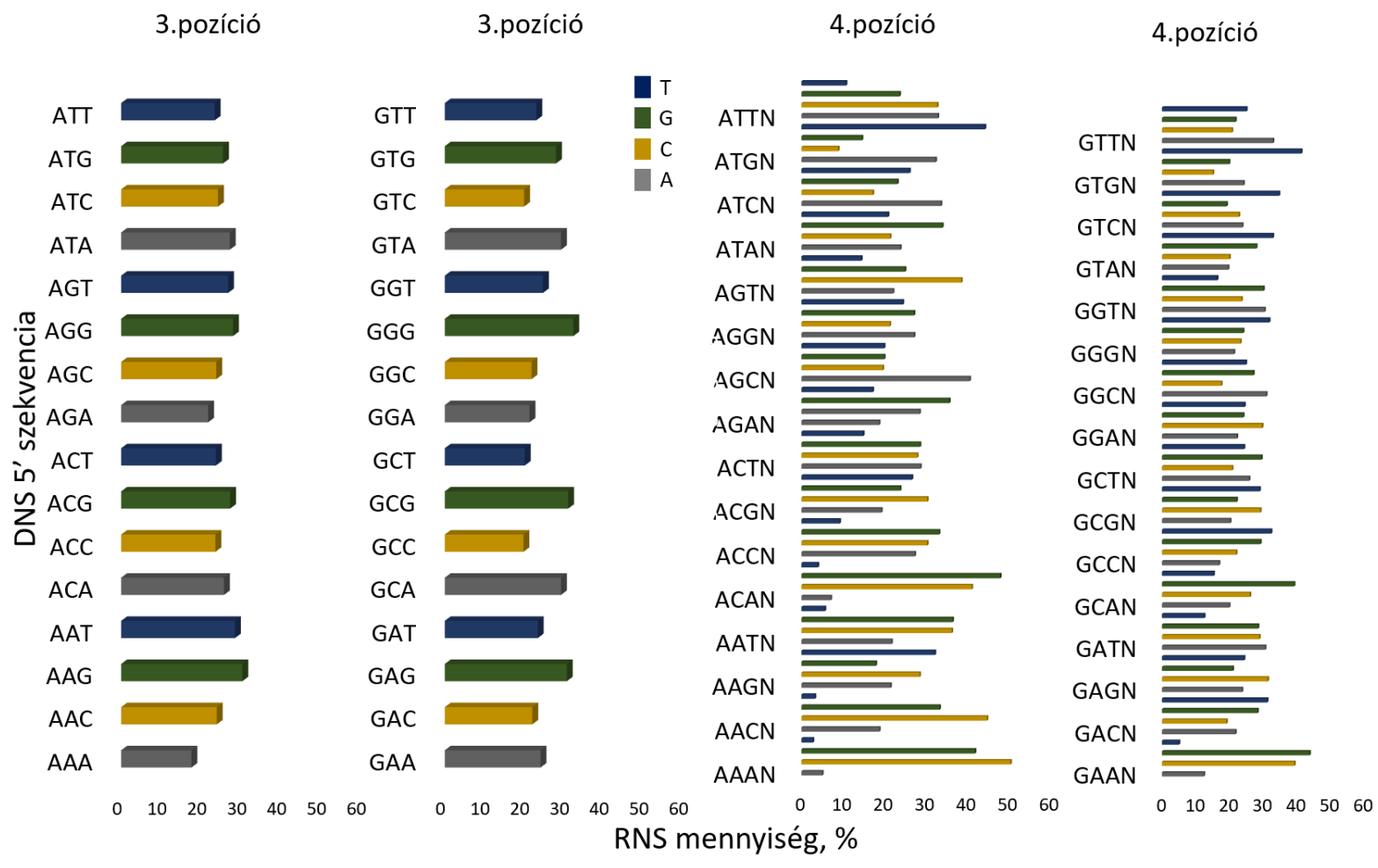

\section{5. Ábra. A +3-as és +4-es pozícióban lévő nukleotidok hatása az RNS expresszióra}

Az ábrán a +3-as, vagy +4-es pozícióban elhelyezkedő különböző nukleotidok hatása látható a J23119 promóterről termelődött RNS-ek mennyiségére. Az ábra az összes transzkripciós iniciációs pozíció transzkriptumainak mennyiségeit mutatja. 1 oszlop megadja, hogy a promótert dowsntream követö 3., vagy 4. bázis adott nukleotidjával átlagosan hány \% RNS keletkezett az összes, a vizsgált pozíciótól upstream elhelyezkedő pozíciók szekvenciájában megegyezö, de a vizsgált pozícióban más nukleotidot tartalmazó szekvenciáról termelődött RNSek összegéhez képest. N=3, amely a 3 cDNS könyvtárnak felel meg. 
A promótert követő első 4 bázisos szekvencia függvényében a fenti eredményeken látható módon változó mennyiségü RNS expresszálódik a J23119 promóterről. A legkisebb és a legnagyobb expressziót biztosító szekvenciákról termelődött RNS mennyiségek átlagai között több, mint 50x-es különbség van +1A-val (AAAT és AGCA) és közel 5x-ös +1G-vel (GAAT és GGCA) (56. ábra). Eredményeink alapján a J23119 promóternél nemcsak a +1 -es pozíció, hanem a továbbiak is befolyásolják a keletkező RNS-ek mennyiségét.

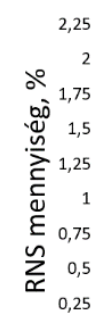

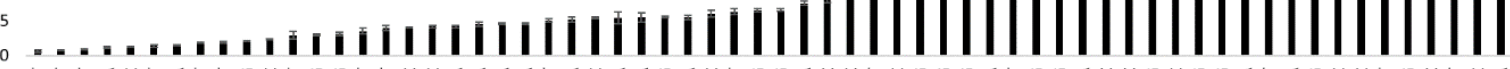

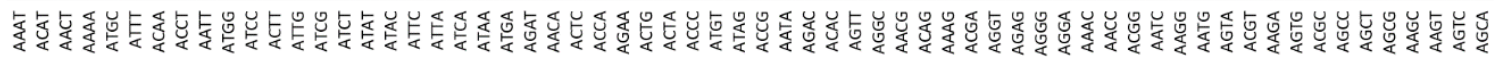
DNS 5' szekvencia

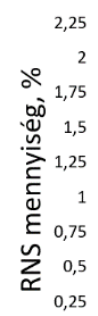

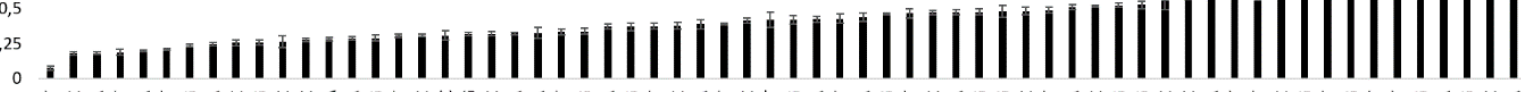

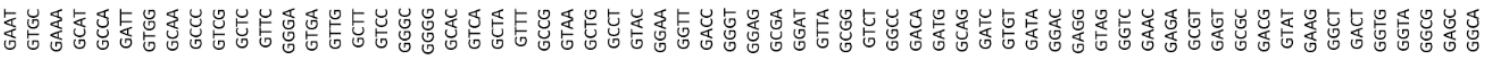
DNS 5' szekvencia

56. Ábra. A J23119 promótert downstream követő négy bázisos szekvencia hatása az RNS expresszióra, ha a +1 A vagy $G$

Az ábrán a +1-től a +4-es pozícióig terjedő szekvencia hatása látható a J23119 promóterről termelődött RNS-ek mennyiségére, ha a +1 -es pozícióban $A$ vagy $G$ van. Az ábra az összes transzkripciós iniciációs pozíció transzkriptumainak mennyiségeit mutatja. 1 oszlop megadja, hogy az összes lehetséges szekvenciáról (256 variáció) termelödött RNS-ek összegéhez képest adott szekvenciáról az RNS-ek hány \%-a keletkezett átlagosan. A hibasávok a százalékos értékek átlagainak szórását mutatják. N=3, amely a 3 cDNS könyvtárnak felel meg. 


\section{Diszkusszió}

\subsection{A Cas12a nukleázok}

A Cas12a nukleázokat néhány éve publikálták először, mint genomszerkesztésre alkalmas módszert és azért nagyon érdekesek, mert más PAM motívumot ismernek fel, emiatt eltérő targetek hasítására képesek, mint a Cas9 nukleázok, ráadásul eltérő módon, mert az Cas9-el szemben a DNS két szálának hasításakor nem tompa, hanem ragadós végeket hoznak létre. Ezen felül később több csoport is megmutatta, hogy alacsonyabb off-target aktivitással bírnak, mint az SpCas9.

A Cpf1 nukleázokkal kapcsolatosan azt kívántuk megvizsgálni, hogy képesek-e hatékony HR javítás indukálására, illetve milyen a hasítási aktivitásuk a Cas9 nukleázokhoz képest. A nukleázok aktivitásának méréséhez egy GFP esszét alkalmaztam egy korábbi esszé alapján, amellyel a nukleáz hasítása nélkül is kaptunk fluoreszcens GFP jelet. A riporter esszét sikeresen módosítottam úgy, hogy ez a hasítás nélküli GFP háttér csökkent. A létrehozott riporter esszé bármilyen nukleáz aktivitásának vizsgálatára alkalmas lehet, és az elmúlt évek alatt már több száz target és számos nukleáz vizsgálatához alkalmaztunk a csoportunkban, illetve több másik publikációnkban szolgált már a nukleázok aktivitásának becslésére.

A GFxFP esszé azért különösen alkalmas a különböző PAM szekvenciákat felismerő nukleázok aktivitásának becslésére, mert a külső okok kizárásával jobban összemérhetőek egymással. Például egy genomi régiót célozva, a különböző PAM szekvenciák szükségességéből adódóan feltételezhetően más-más genomi környezet, epigenetikai állapot lehetne az egyes targetek között, amely befolyásolhatná a nukleázok aktivitását. Továbbá, a HR javítást nagyban befolyásolja a targetek távolsága a homológ karoktól. Ennek a hatásnak az elkerülése érdekében különböző nukleázok összehasonlításakor a megfelelő PAM-szekvenciákkal rendelkező targeteknek szinte azonos genomi pozícióban kéne elhelyezkedni. Ez azonban messze nem jelent triviális feladatot az eltérő PAM szekvenciák miatt. Az alkalmazott GFP riporter esszé alkalmazásával mindezek kiküszöbölhetőek. Ezen túlmenően a HR javítás hatékonyságának vizsgálata genomi targeteken körülbelül kilenc-tizennégy napig tart, míg a GFxFP esszé elvégzéséhez csak négy nap szükséges, ami további előny. Eredményeink azt mutatják, hogy a két Cas12a nukleáz ugyanolyan, vagy egyes targeteken nagyobb hatékonysággal képes müködni, mint az SpCas9 legszélesebb körben alkalmazott Cas9 társai, és aktivitásuk az SpCas9 aktivitásával összemérhető szinten van. 
Megmutattuk, hogy a Cas12a nukleázok képesek genomi pozíciókat célozva is hatékony HR javítás kiváltására. Eredményeink alapján a Cas12a nukleázok hatékonyan képesek DNSrekombinációs javítást indukálni homológ szekvenciák alapján riporter plazmidot célozva és genomi targeteken is az N2a sejtekben- mely más sejtvonal, mint a humán HEK-293FT sejtek, melyben Zetsche és mtsai mutatták be a Cas12a nukleázokkal végzett úttörő kísérleteiket. Ezen kívül ők csak kettő darab targeten, és csak NHEJ javítással vizsgálták a Cas12a nukleázok aktivitását.

Eredményeink arra utalnak, hogy a Cas12a nukleázok fontos helyet foglalnak el az SpCas9 mellett a genomszerkesztési eszközök palettáján. Ezt az elmúlt években számos csoport is megerősítette és megmutatta a Cas12a nukleázok alkalmasságát génszerkesztésre különböző organizmusokban $^{78}$.

\subsection{A megnövelt specificitású SpCas9 variánsok}

A CRISPR rendszerek egyik legnagyobb hátránya az off-target hatás, melynek kiküszöbölésére irányuló egyik módszer a megnövelt specificitású Cas9 variánsok létrehozása. Kutatásunk egy része, amelyet a disszertációmban is bemutattam, arra irányult, hogy a két, elsőként publikált megnövelt specificitású SpCas9 variáns, az eSpCas9 és a SpCas9-HF1 hasítási aktivitását vizsgáljuk meg a különböző gRNS módosításokkal, melyekre akkor lehet szükség, ha a target nem G-vel kezdődik. Ezek közül a módosítások közül a guideRNS 5' végén elhelyezkedő utolsó nukleotid G-re cserélését, vagy a spacer változatlanul hagyását, továbbá a gRNS-ek 5' végének rövidítését teszteltük le. Azt az eredményt kaptuk, hogy a gRNS-ek 5' végének bármely fent bemutatott módosítása jobban csökkenti a megnövelt specificitású SpCas9 variánsok aktivitását, mint a WT SpCas9-ét. Valószínűleg a megnövelt specificitású Cas9 variánsok azért nem müködnek jól az 5'-végükben nem egyező, vagy rövidebb gRNS-ekkel, mert módosításaik következtében kevésbé tolerálják, ha a spacer és a target között eltérés van (azaz érzékenyek a DNS-RNS hibrid strukturális változásaira, amely a fehérjeszerkezet belsejében helyezkedik el). Eredményeink közlése óta már több másik megnövelt specificitású SpCas9 variánst is létrehoztak (lásd. 2.2. fejezet). Eredményeink publikálását követően többen is megerősítették, hogy a megnövelt specificitású SpCas9 variánsok rutinszerüen csak a teljesen egyező 20 nukleotid hosszú spacerekkel használhatók ${ }^{48,49}$. Ahhoz, hogy a megnövelt specificitású nukleáz variánsokat ne csak G-kezdetű targetekkel lehessen hatékonyan használni, több megoldás létezhet. Az egyik, hogy tovább mutálva a nukleázt, jobban elfogadják ezeket a gRNS módosításokat, azonban ez azzal járhat, hogy aktivitásuk a kívánt targeteken is csökken ${ }^{79}$. 
A G-vel kezdődő targetek használata azért terjedt el a CRISPR gRNS-ek expressziójára, mert az emlösökben leginkább használt U6 és az in vitro használt T7 promóterekröl számos csoport azt állította, hogy a promóterektől downstream elhelyezkedő első pozícióban G nukleotid szükséges a hatékony gRNS expresszióhoz. Ezért célszerünek tűnik megvizsgálni, hogy a gRNS expresszióra általában alkalmazott promóterek esetében megfelelő-e az expresszió más nukleotidokról is, ami által a megnövelt specificitású nukleázokkal alkalmazható targetek köre is bővülhet.

\subsection{A CRISPR gRNS-ek expressziójára gyakran alkalmazott promóterek}

Mivel a Cas nukleázok működését befolyásolja a gRNS-ek mennyisége és hossza, ezért rendkívül fontos, hogy pontos ismereteink legyenek az alkalmazott promóterekröl. Több tanulmány szerint az, hogy milyen nukleotidok vannak a +1-es pozícióban és környezetében, befolyásolhatja az RNS expressziót és a transzkripció iniciáció pozícióját is. Bár néhány általunk vizsgált promóter esetében a +1-es pozícióban elhelyezkedő nukleotidok szerepét már vizsgálták szisztematikusan, de a továbbiakat még nem.

A doktori értekezésem alapjául szolgáló kísérleteinkben a +1 -es pozíción túl a promótertől downstream elhelyezkedő további 3 pozícióban található nukleotidok szerepét is megvizsgáltuk az RNS expresszióra és a transzkripció kezdő pozíciójára. Kutatásainkban a CRISPR gRNS-ek expressziójára gyakran alkalmazott promóterek közül a humán U6, a humán 7sk, a T7, az U6T7 és a J23119 promótereket vizsgáltuk meg.

\subsubsection{Az U6 promóter}

Az U6 promótert vizsgálva megerősítettük, ha a promótertől downstream elhelyezkedő első pozícióban pirimidin található, csak kis arányban indul a +1-ről a transzkripció. Megmutattuk, hogy ebben az esetben a további pozíciók erősen befolyásolják, hogy melyik pozícióról milyen arányban indul el az átírás, így primidinről nagyon heterogén hosszúságú RNS-ek termelődnek. Megerősítettük, ha a +1-es pozícióban purin van, nagyrészt a +1-ről indul el a transzkripció. Megmutattuk, hogy a pirimidinekkel szemben itt a további pozíciók kevésbé befolyásolják a transzkripció iniciáció pozícióját. Megerősítettük, hogy a +1-es pozícióban pirimidinről szignifikánsan kevesebb RNS íródik át, mint purinokról. A +1A-ról és +1G-ről expresszálódó RNS-ek mennyiségében nem találtunk szignifikáns különbséget. Eredményeink alapján az U6 promótertől downstream elhelyezkedő további 3 pozíció szekvenciája is befolyásolja a keletkező RNS-ek mennyiségét. 
A továbbiakban abból az okból kifolyólag, hogy +1-es pozícióban pirimidint tartalmazó szekvenciákkal nem nagyrészt a +1 -es pozíció volt a transzkripció kezdő helye, már csak a +1 ben purint tartalmazó szekvenciákat vizsgálva azt kaptuk, hogy a +2-es pozíció is fontos szerepet játszik az RNS-ek mennyiségében. A legtöbb RNS az U6 promóterről akkor keletkezik, ha a promótert AG, vagy GG dinukleotid követi, amelyek a legkisebb expressziójú GC kezdetű szekvenciákhoz képest kétszerannyi RNS-t biztosítanak. A promótertől dowsntream elhelyezkedő 3-4. pozíció a tőle upstream elhelyezkedő szekvencia függvényében változóan befolyásolja az RNS mennyiségét, de akár többszörös RNS mennyiségbeli különbségeket okozhat e pozíciók szekvenciája is. Eredményeink szerint az U6 promótert downstream követő első 4 bázisos szekvenciák függvényében változó mennyiségű RNS expresszálódik az U6 promóterről, és a legkisebb és a legnagyobb expressziót biztosító szekvenciákról termelődött RNS mennyiségek átlagai között egy nagyságrendnyi különbség van.

\subsubsection{A 7sk promóter}

A 7sk promóterről azt találtuk, hogy promóter utáni szekvenciák hasonlóképp befolyásolják a transzkripciós iniciáció pozícióját, mint az U6 promóternél, így míg +1 purinnal a transzkripció iniciációja közel minden esetben a +1 , a +1 pirimidinről keletkezett RNS-ek nagy része nem a +1-ről indul, és így többféle hosszúságú RNS keletkezik. Így alaposabb vizsgálatokat a továbbiakban a +1-ben purint tartalmazó szekvenciákkal végeztünk.

Eredményeink alapján $+1 \mathrm{G}$-vel összességében mintegy 30\%-al több RNS termelődik, mint +1A-val, de az RNS mennyiség függ a további pozíciók szekvenciájától is. Az U6 promóterhez hasonlóan szintén befolyásolja az RNS expressziót a +2- +4-es pozíciók szekvenciája is. A második pozíció tekintetében a legtöbb RNS a 7sk promóterről akkor keletkezik, ha a promótert az AG, a GG és GT dinukleotidok követik, amelyek esetében több, mint kétszer magasabb RNS szint érhető el átlagban, mint a legalacsonyabb RNS szintet biztosító purin kezdetü dinukleotidról. Az RNS mennyiséget a +3-4. pozíciók nukleotidjai itt is az upstream elhelyezkedő szekvenciától függő mértékben befolyásolják. A promótert követő 4 bázisos szekvenciák +1A-val 27x-es, +1G-vel több, mint 7x-es RNS mennyiségbeli különbséget okozhatnak.

Megmutattuk, hogy a 7sk és az U6 promóter hasonló expressziós szintet biztosít HEK-293 sejtekben, így a 7sk akár párhuzamosan, vagy akár az U6 helyett használva is alkalmas lehet gRNS expresszióra. 


\subsubsection{A $T 7$ promóter}

A T7 promóter a méréseink szerint az irodalommal egybecsengően a +1 -es pozícióban a guanint preferálja. Meglepő módon azonban azt találtuk, hogy vannak olyan, a +1-es pozícióban A-t tartalmazó szekvenciák is, amelyek elérik a +1G-ről termelődő RNS-ek mennyiségét és az átírás is nagyrészt +1 -ről indul el. A T7 promótert követő 4 nukleotid összes variációjáról keletkezett RNS-eket vizsgálva megállapítottuk, hogy az AG dinukleotidokról kezdődő szekvenciák esetében átlag 84\%-ban, míg a +1-ben G-t tartalmazó szekvenciák esetében átlag 90\%-ban pontos, +1-ről induló a transzkripció, amit a +2- +4 pozíciók szekvenciája már csak nagyon kis mértékben befolyásol. Érdekes módon azt találtuk, hogy az AG-vel kezdődő szekvenciák átlagosan azonos mennyiségü RNS szintet biztosítanak, mint a +1G-vel legnagyobb RNS szintet biztosító GA kezdetű szekvenciák. Irodalmi adatok alapján nem konzisztens, hogy a T7 promóterhez a promótertől downstream egy, kettő vagy 3 darab G-t érdemes használni. Megmutattuk, hogy a GG és GGG szekvenciákról csak fele- illetve negyedannyi transzkript keletkezik, mint a GA kezdetűekről. Az RNS mennyiséget a +3 és +4 pozíciók nukleotidjai is szignifikánsan, a tölük upstream elhelyezkedő szekvenciától függő mértékben befolyásolják. A legkisebb és a legnagyobb expressziót biztosító 4 bázisos szekvenciákról termelődött RNS mennyiségek átlagai között közel 5x-ös különbség van AG kezdettel és több, mint $13 \mathrm{x}$-os $+1 \mathrm{G}$-vel.

\subsubsection{Az U6T7 promóter}

Az U6T7 hibrid promótert bemutató cikk szerint legalább egy G-vel kell alkalmazni, de a promótertől elhelyezkedő nukleotidok szerepét az RNS expresszióra, vagy a transzkripció iniciációs pozíciókra eddig nem vizsgálták. Az U6T7 promóterrel azt kaptuk, hogy itt is befolyásolják a transzkripciós iniciáció pozícióját a promótertől downstream elhelyezkedő nukleotidok. Azonban míg az összes általunk vizsgált promóternél a purinokról, vagy legalább a guaninról majdnem 100\%-ban a +1-ről indul el az átírás, az U6T7 promóternél sokkal heterogénebb a transzkripció iniciációjának pozíciója. Az összes promóterhez képest sokkal nagyobb arányban indul el az átírás a -1-röl, még guaninnal is átlagosan 30\%-ban. A +1-es pozíciót vizsgálva azt találtuk, hogy még akkor is alacsony arányban indul el +1-ről az átírás, ha az purin, pirimidinről pedig kiemelkedően kis arányban indul el pontosan az átírás a többi promóterrel összehasonlítva. Eredményeink szerint a módosított hibrid promóternél, bár T7 polimerázzal jól használható, emlős expresszióhoz figyelembe kell venni, hogy hiába expresszál az U6, 7sk promóterekhez hasonló mennyiségben RNS-t, de nagyon heterogén hosszúságú RNS-ek keletkeznek róla, még a +1-es pozícióban purinról is. 
Ma és munkatársai az U6 promóter olyan módosított változatainál, amelyekben a +1-től upstream elhelyezkedő szekvenciákat módosították hasítóhelyek bevitelének érdekében, jelentős eltéréseket tapasztaltak az RNS iniciáció tekintetében, pontatlanná vált az RNS 5' végének átírása ${ }^{52}$. Esetünkben az U6 és U6T7 utolsó 18 bázisa jelentősen eltér, ezért feltételezhetjük, hogy a fent említett megfigyeléssel megegyező okokból, azaz a +1-es pozíciótól upstream elhelyezkedő szekvenciák módosításának következtében fordulhat elő az, hogy a hibrid promóternek az eredeti promóterhez képest nagymértékben heterogénebb az iniciációs kezdő pozíciója. Feltételezhetően ennek az az oka, hogy ezzel a módosítással flexibilisebbé válik a transzkripciós buborék (lásd 6.3.6. fejezet). Eredményeink és gRNS szekvenáló módszerünk felhasználásával érdekes lehetne egy olyan U6T7 promóter megalkotása, amely emlős rendszerekben is homogén hosszúságú RNS-ek transzkripciójára képes.

\subsubsection{A J23119 promóter}

Tudomásunk szerint a J23119 promóternél eddig nem vizsgálták, hogy milyen hatással vannak a promótertől downstream elhelyezkedő nukleotidok az RNS expresszióra és a transzkripció kezdő helyére. Eredményeink alapján a J23119 promótert downstream követő nukleotidok szintén befolyásolják a kezdő pozíciót. Habár kisebb arányban indul el pontosan az átírás, ha $\mathrm{a}+1$ pirimidin $\mathrm{a}+1$ purinokhoz képest, de a többi vizsgált promóterhez képest több a $+1-b o ̋ l$ átíródó RNS pirimidinekről is. Ha a $+1 \mathrm{~A}$ vagy $\mathrm{G}$, szinte majdnem mindig a +1 -ben kezdődik az átírás. Nincs jelentős eltérés $+1 \mathrm{~A}$ és $+1 \mathrm{G}$ között abban, hogy milyen pontos a transzkripció iniciációja. A különböző promótertől downstream elhelyezkedő szekvenciák befolyásolják a keletkező RNS-ek mennyiségét is. Megmutattuk, hogy a legtöbb RNS akkor keletkezik, ha a +1-ben purin van. Eredményeink alapján a J23119 promóterről keletkezett RNS mennyiségét is szignifikánsan befolyásolja a $+2-+4$ pozíciók szekvenciája is. A promótert követő első 4 bázisos szekvencia +1A-val akár 50x-es, +1G-vel pedig közel 5x-ös különbséget is okozhat a legjobb és a legrosszabb szekvenciákról termelődött RNS-ek mennyiségében. 


\subsubsection{Konklúzió}

Jelenlegi ismereteink szerint egyik általunk vizsgált promóterről sincs a promótertől downstream elhelyezkedő nukleotidok RNS expresszióra és kezdő pozíciókra gyakorolt hatásairól megközelítőleg sem hasonlóan átfogó tanulmány a mi kutatásainkhoz képest. Egy bakteriális promóterről csináltak egy hasonlóan mélyreható vizsgálatot Vedenskaya és mtsai ${ }^{80}$, akik azt kapták, hogy mind a kezdő pozíciókra, mind az RNS expresszióra nézve összességében előnyösebb, ha a +1-ben purin van, de a további pozíciók is számítanak és jellemzően azokban is purin preferenciát tapasztaltak. A doktori értekezésem alapjául szolgáló kísérleteinkben a kiválasztott promóterek sokkal átfogóbb vizsgálatát végeztük el az eddigiekhez képest. Nemcsak a +1-es pozíció, de a tőle downstream elhelyezkedő további 3 bázis hatását is megvizsgáltuk az RNS mennyiségekre és a transzkripció iniciációs pozíciókra. A promóterekre irányuló vizsgálatainkat szekvenciánként nagy lefedettséggel végeztük el a legmodernebb technikák közé tartozó újgenerációs szekvenálás segítségével.

Eredményeink alapján az összes általunk vizsgált promóternél rendkívül nagy szerepet játszik mind az RNS expresszióra, mind a kezdő pozíciókra a promótertől downstream elhelyezkedő szekvencia. Mindkét esetben, mind a 4 promóter utáni pozíció különböző nukleotidjai szignifikáns különbségeket okozhatnak. Kísérleteink alapján a +1-es pozícióban elhelyezkedő nukleotid nem határozza meg a további szekvenciától függetlenül az expressziós szintet, hanem azt a további pozíciók nukleotidjai is jelentősen befolyásolják. Így előfordulhat, hogy nagyságrendbeli különbségek lehetnek az RNS mennyiségekben a +2- +4 pozíciók függvényében, hiába azonos a +1 -es pozíció nukleotidja. Mivel az RNS-ek mennyiségét számos külső tényező befolyásolhatja, ezért kísérleteinket az RNS-t kódoló szakaszba épített randomizált bárkódoknak köszönhetően rengeteg különböző RNS szekvenciával végeztük el. Ezzel kívántuk elkerülni a vizsgált 4 bázisos szekvencia expresszióbeli különbségein kívül adódó külső hatásokat, mint például az RNS szerkezetbeli különbségek okozta RNS degradációt.

Több csoport is bemutatta, hogy számos promóternél a promótertől downstream elhelyezkedő nukleotidok a transzkripciós kezdő pozíciókat is befolyásolják ${ }^{80-85}$. A legfrissebb nézet ennek magyarázatára, hogy a transzkripció iniciációjakor a promóternél szétváló kettősszálú DNS, a transzkripciós buborék mérete nem fix. A transzkripciós buborék méretét számos tényező befolyásolhatja, akár a +1-es pozíció környezetében elhelyezkedő szekvencia is, amelyek ahhoz vezethetnek, hogy a transzkripció iniciációja nem egy fix pozícióról történik, hanem különböző arányban akár több pozícióról is, így pedig nem megegyező hosszúságú RNS-ek 
keletkezhetnek $^{80,86}$. Az 5 promótert is megvizsgáló kísérleteink alapján megfigyeltük, hogy az összes promóternél befolyásolja a kezdő pozíciókat a promótertől downstream elhelyezkedő szekvencia. Mindegyik promóternél azt kaptuk, hogy ha a promótertől downstream az első pozícióban pirimidin van, sokkal kisebb arányban lesz a +1 -es pozíció a kezdő pozíció, és ilyenkor nem egy fix pozícióról indul el az átírás. Abban az esetben, ha a +1-ben pirimidin van, mindegyik promóter esetében nagymértékben befolyásolta nemcsak a promótert követő első, hanem a többi azt követő nukleotid is, hogy melyik kezdő pozícióról milyen arányban indult el az átírás. U6T7 promóteres eredményeink, Ma és mtsai-nak eredményeivel ${ }^{52}$ megegyezően azt mutatták, hogy az U6 promóter TATA box utáni módosítása heterogén transzkripciós kezdő pozíciókat eredményez, akkor is, ha a +1-es pozícióban purin van. Ebből az következik, hogy a +1-től upstream elhelyezkedő szekvenciák is befolyásolják a transzkripciós kezdő pozíciókat.

A promóterekkel kapcsolatos eredményeink több okból is jelentősek lehetnek. Egyrészt, mivel összesen 5 promótert vizsgáltunk meg, melyek 3 különböző organizmusból származnak, ezért azon megállapításaink, hogy a promótertől downstream elhelyezkedő szekvenciák (és nemcsak az első pozíció nukleotidja), mind az RNS expressziót, mind a transzkripció iniciációját befolyásolja, feltételezhetően számos másik promóterre is igazak lehetnek. Ez nemcsak az alkalmazott kutatásokban, hanem az alapkutatás szintjén is nagyon érdekes megállapítás és felveti más promóterek és további pozíciók vizsgálatának szükségszerüségét. Másrészt, eredményeink alapján a vizsgált promótereknél adott szekvenciákkal magasabb expressziós szint, valamint homogénebb hosszúságú transzkriptumok érhetőek el. Ez rendkívül hasznos lehet különböző alkalmazások számára, többek között a CRISPR/Cas rendszerekhez, mert a gRNS-ek 5' végének hossza és a gRNS-ek mennyisége is nagymértékben befolyásolhatja a nukleázok aktivitását. Érdekes lehet akár az RNS interferenciát alkalmazva is, amelyhez szintén gyakran ugyanezeket a promótereket használják. Eddig a CRISPR-es alkalmazásoknál az volt az elterjedt gyakorlat, hogy emlős sejtekben az U6 és 7sk promótereket használva, vagy in vitro a T7 promóterrel szinte kizárólag olyan targeteket választanak, amelyekben a spacer 5' első bázisának megfelelő bázis G. Eredményeink alapján a CRISPR-hez választható targetek köre bővülhet. Eredményeink felhasználásának további érdekes lehetősége- az esetlegesen a további pozíciókra a jövőben lefolytatott eredményekkel együtt- a különböző CRISPR rendszerek hatékonyabb használatához kifejlesztett predikciós programokba való beépítése, melyek segítségével még hatékonyabb célszekvenciák lennének jósolhatók a CRISPR-es alkalmazásokhoz. 


\section{Köszönetnyilvánítás}

Köszönetemet elsőként témavezetőmnek, Dr. Welker Ervinnek szeretném kifejezni, amiért lehetőséget nyújtott, hogy a kutatócsoportjában dolgozzak. Nagyon hálás vagyok, hogy az elmúlt években magas színvonalú kutatásokban vehettem részt és számos molekuláris biológiai módszert tanulhattam meg, egy kiváló csapatban.

Köszönettel tartozom a labor jelenlegi és volt munkatársainak: Szücsné Pulinka Ildikó, Szücs Judit, Huszár Krisztina, Dr. Tóth Eszter, Dr. Kulcsár Péter István, Tálas András, Krausz Sarah Laura, Ligeti Zoltán, Varga Éva, Dr. Nyeste Antal, Dr. Fodor Elfrieda, Vida István, Bencsura Petra, Dr. Borsy Adrienn, Cserkutiné Czene Bernadett, Pájer-Turgyán Luca Xénia.

Külön köszönet illeti Dr. Tóth Esztert a Cpfl-ekkel kapcsolatos munkájáért és a kooperálásért, Dr. Kulcsár Péter Istvánt és Huszár Krisztinát a disszertációmban bemutatott megnövelt specificitású SpCas9 variánsokkal folytatott munkájukért és Dr. Sturm Ádámot a promóterek vizsgálatával kapcsolatos összes programozási munkájáért.

Hálásan köszönöm az egész Welker-csoportnak, hogy az elmúlt években ilyen remek hangulatú, motiváló légkörben folytathattam doktori kutatásaimat.

Köszönettel tartozom Dr. Szeri Flórának és Dr. Schamberger Anitának, hogy elolvasták és észrevételeikkel jelentősen javították értekezésem színvonalát.

Egész családomnak nagyon szépen köszönöm a rengeteg támogatást, bíztatást, türelmet. 


\section{Közremüködések}

A 14. ábrán látható eredmények közül a plazmid konstrukciók elkészítésétől a kiértékelésig a 20. pozícióban nem G-t tartalmazó guideRNS-ek megnövelt specificitású SpCas9 variánsokra kifejtett hatásával kapcsolatos vizsgálatok minden lépését teljes mértékben én végeztem el. Az ezzel kapcsolatban a disszertációmban bemutatott további eredményekhez Dr. Kulcsár Péter István és Huszár Krisztina végezték el a többi kísérletet.

A disszertációmban bemutatott Cas12a nukleázok vizsgálatával kapcsolatos kísérletekben Dr. Tóth Eszterrel együtt végeztük el a kísérletek nagy részét, egymás között felosztva a klónozási, sejttenyésztési, mérési és kiértékelési feladatokat, a GFxFP rendszer továbbfejlesztésén és tesztelésén kívül, melyet önállóan végeztem. A sejtfenntartásban, transzfekcióban és a citometriás mérésekben Bencsura Petra is segített. Huszár Krisztina és Dr. Kulcsár Péter István klónozással, Tálas András pedig citometriás méréssel segítette a munkát.

A promóterek vizsgálatával kapcsolatos összes kísérletes munkát, azok kiértékelését és a statisztikát önállóan végeztem. Ez alól kivétel az NGS eredmények kiértékelése, amelyhez Dr. Sturm Ádám nyújtott segítséget, az összes 4.11. fejezetben felsorolt programozási feladatot Pythonban ö végezte el. 


\section{Irodalomjegyzék}

Barrangou, R. \& Doudna, J. A. Applications of CRISPR technologies in research and beyond. Nat Biotechnol 34, 933-941, doi:10.1038/nbt.3659 (2016).

Barman, A., Deb, B. \& Chakraborty, S. A glance at genome editing with CRISPR-Cas9 technology. Curr Genet 66, 447-462, doi:10.1007/s00294-019-01040-3 (2020).

Amitai, G. \& Sorek, R. CRISPR-Cas adaptation: insights into the mechanism of action. Nat Rev Microbiol 14, 6776, doi:10.1038/nrmicro.2015.14 (2016).

Puschnik, A. S., Majzoub, K., Ooi, Y. S. \& Carette, J. E. A CRISPR toolbox to study virus-host interactions. Nat Rev Microbiol 15, 351-364, doi:10.1038/nrmicro.2017.29 (2017).

Jinek, M. et al. A programmable dual-RNA-guided DNA endonuclease in adaptive bacterial immunity. Science 337, 816-821, doi:10.1126/science.1225829 (2012).

Komor, A. C., Badran, A. H. \& Liu, D. R. CRISPR-Based Technologies for the Manipulation of Eukaryotic Genomes. Cell 169, 559, doi:10.1016/j.cell.2017.04.005 (2017).

Moon, S. B., Kim, D. Y., Ko, J. H. \& Kim, Y. S. Recent advances in the CRISPR genome editing tool set. Exp Mol Med 51, 1-11, doi:10.1038/s12276-019-0339-7 (2019).

Eid, A., Alshareef, S. \& Mahfouz, M. M. CRISPR base editors: genome editing without double-stranded breaks. Biochem J 475, 1955-1964, doi:10.1042/BCJ20170793 (2018).

Komor, A. C., Kim, Y. B., Packer, M. S., Zuris, J. A. \& Liu, D. R. Programmable editing of a target base in genomic DNA without double-stranded DNA cleavage. Nature 533, 420-424, doi:10.1038/nature17946 (2016). Strecker, J. et al. RNA-guided DNA insertion with CRISPR-associated transposases. Science 365, 48-53, doi:10.1126/science.aax9181 (2019).

Anzalone, A. V. et al. Search-and-replace genome editing without double-strand breaks or donor DNA. Nature 576, 149-157, doi:10.1038/s41586-019-1711-4 (2019).

Hu, J. H. et al. Evolved Cas9 variants with broad PAM compatibility and high DNA specificity. Nature 556, 57-63, doi:10.1038/nature26155 (2018).

Nishimasu, H. et al. Engineered CRISPR-Cas9 nuclease with expanded targeting space. Science 361, 1259-1262, doi:10.1126/science.aas9129 (2018).

Mout, R., Ray, M., Lee, Y. W., Scaletti, F. \& Rotello, V. M. In Vivo Delivery of CRISPR/Cas9 for Therapeutic Gene Editing: Progress and Challenges. Bioconjug Chem 28, 880-884, doi:10.1021/acs.bioconjchem.7b00057 (2017).

Zuo, Z. \& Liu, J. Allosteric regulation of CRISPR-Cas9 for DNA-targeting and cleavage. Curr Opin Struct Biol 62, 166-174, doi:10.1016/j.sbi.2020.01.013 (2020).

Slaymaker, I. M. et al. Rationally engineered Cas9 nucleases with improved specificity. Science 351, 84-88, doi:10.1126/science.aad5227 (2016).

Jiang, F. et al. Structures of a CRISPR-Cas9 R-loop complex primed for DNA cleavage. Science 351, 867-871, doi:10.1126/science.aad8282 (2016).

Chen, J. S. et al. Enhanced proofreading governs CRISPR-Cas9 targeting accuracy. Nature 550, 407-410, doi:10.1038/nature24268 (2017).

Babu, K. et al. Bridge Helix of Cas9 Modulates Target DNA Cleavage and Mismatch Tolerance. Biochemistry 58 , 1905-1917, doi:10.1021/acs.biochem.8b01241 (2019).

Casini, A. et al. A highly specific SpCas9 variant is identified by in vivo screening in yeast. Nat Biotechnol 36 265-271, doi:10.1038/nbt.4066 (2018).

Lee, J. K. et al. Directed evolution of CRISPR-Cas9 to increase its specificity. Nat Commun 9, 3048, doi:10.1038/s41467-018-05477-x (2018).

Fu, Y., Sander, J. D., Reyon, D., Cascio, V. M. \& Joung, J. K. Improving CRISPR-Cas nuclease specificity using truncated guide RNAs. Nat Biotechnol 32, 279-284, doi:10.1038/nbt.2808 (2014).

Kim, D., Kim, S., Kim, S., Park, J. \& Kim, J. S. Genome-wide target specificities of CRISPR-Cas9 nucleases revealed by multiplex Digenome-seq. Genome Res 26, 406-415, doi:10.1101/gr.199588.115 (2016).

Yin, H. et al. Partial DNA-guided Cas9 enables genome editing with reduced off-target activity. Nat Chem Biol 14, 311-316, doi:10.1038/nchembio.2559 (2018).

Ryan, D. E. et al. Improving CRISPR-Cas specificity with chemical modifications in single-guide RNAs. Nucleic Acids Res 46, 792-803, doi:10.1093/nar/gkx1199 (2018).

Cromwell, C. R. et al. Incorporation of bridged nucleic acids into CRISPR RNAs improves Cas9 endonuclease specificity. Nat Commun 9, 1448, doi:10.1038/s41467-018-03927-0 (2018).

Guilinger, J. P., Thompson, D. B. \& Liu, D. R. Fusion of catalytically inactive Cas9 to FokI nuclease improves the specificity of genome modification. Nat Biotechnol 32, 577-582, doi:10.1038/nbt.2909 (2014).

Kim, Y. B. et al. Increasing the genome-targeting scope and precision of base editing with engineered Cas9cytidine deaminase fusions. Nat Biotechnol 35, 371-376, doi:10.1038/nbt.3803 (2017).

Li, X. et al. Base editing with a Cpf1-cytidine deaminase fusion. Nat Biotechnol 36, 324-327, doi:10.1038/nbt.4102 (2018).

Kim, D. et al. Genome-wide target specificities of CRISPR RNA-guided programmable deaminases. Nat Biotechnol 35, 475-480, doi:10.1038/nbt.3852 (2017).

Senturk, S. et al. Rapid and tunable method to temporally control gene editing based on conditional Cas9 stabilization. Nat Commun 8, 14370, doi:10.1038/ncomms14370 (2017). 
Zhang, J., Chen, L., Zhang, J. \& Wang, Y. Drug Inducible CRISPR/Cas Systems. Comput Struct Biotechnol J 17, 1171-1177, doi:10.1016/j.csbj.2019.07.015 (2019).

Shen, B. et al. Efficient genome modification by CRISPR-Cas9 nickase with minimal off-target effects. Nat Methods 11, 399-402, doi:10.1038/nmeth.2857 (2014). Kleinstiver, B. P. et al. Genome-wide specificities of CRISPR-Cas Cpf1 nucleases in human cells. Nat Biotechnol 34, 869-874, doi:10.1038/nbt.3620 (2016). Toth, E. et al. Cpf1 nucleases demonstrate robust activity to induce DNA modification by exploiting homology directed repair pathways in mammalian cells. Biol Direct 11, 46, doi:10.1186/s13062-016-0147-0 (2016). Hur, J. K. et al. Targeted mutagenesis in mice by electroporation of Cpf1 ribonucleoproteins. Nat Biotechnol 34, 807-808, doi:10.1038/nbt.3596 (2016). doi:10.1016/j.cell.2015.09.038 (2015) Vanegas, K. G., Jarczynska, Z. D., Strucko, T. \& Mortensen, U. H. Cpf1 enables fast and efficient genome editing in Aspergilli. Fungal Biol Biotechnol 6, 6, doi:10.1186/s40694-019-0069-6 (2019). Hsu, P. D. et al. DNA targeting specificity of RNA-guided Cas9 nucleases. Nat Biotechnol 31, 827-832, doi:10.1038/nbt.2647 (2013). Ryan, O. W. et al. Selection of chromosomal DNA libraries using a multiplex CRISPR system. Elife 3, doi:10.7554/eLife.03703 (2014). Min, Y. L. et al. CRISPR-Cas9 corrects Duchenne muscular dystrophy exon 44 deletion mutations in mice and human cells. Sci Adv 5, eaav4324, doi:10.1126/sciadv.aav4324 (2019). Schoger, E. et al. CRISPR-Mediated Activation of Endogenous Gene Expression in the Postnatal Heart. Circ Res 126, 6-24, doi:10.1161/CIRCRESAHA.118.314522 (2020).

Dahlman, J. E. et al. Orthogonal gene knockout and activation with a catalytically active Cas9 nuclease. Nat Biotechnol 33, 1159-1161, doi:10.1038/nbt.3390 (2015). doi:10.1038/nmeth.3580 (2015).

Tsai, S. Q. et al. GUIDE-seq enables genome-wide profiling of off-target cleavage by CRISPR-Cas nucleases. Nat Biotechnol 33, 187-197, doi:10.1038/nbt.3117 (2015). Wienert, B. et al. Unbiased detection of Genome Res 24, 132-141, doi:10.1101/gr.162339.113 (2014)

Kulcsar, P. I. et al. Crossing enhanced and high fidelity SpCas9 nucleases to optimize specificity and cleavage. Genome Biol 18, 190, doi:10.1186/s13059-017-1318-8 (2017).

Zhang, D. et al. Perfectly matched 20-nucleotide guide RNA sequences enable robust genome editing using highfidelity SpCas9 nucleases. Genome Biol 18, 191, doi:10.1186/s13059-017-1325-9 (2017).

50 Kim, S., Bae, T., Hwang, J. \& Kim, J. S. Rescue of high-specificity Cas9 variants using sgRNAs with matched 5' nucleotides. Genome Biol 18, 218, doi:10.1186/s13059-017-1355-3 (2017).

51 Gao, Z., Harwig, A., Berkhout, B. \& Herrera-Carrillo, E. Mutation of nucleotides around the +1 position of type 3 polymerase III promoters: The effect on transcriptional activity and start site usage. Transcription $\mathbf{8}, 275-287$, doi:10.1080/21541264.2017.1322170 (2017).

Ma, H. et al. Pol III Promoters to Express Small RNAs: Delineation of Transcription Initiation. Mol Ther Nucleic Acids 3, e161, doi:10.1038/mtna.2014.12 (2014).

Helm, M., Brule, H., Giege, R. \& Florentz, C. More mistakes by T7 RNA polymerase at the 5' ends of in vitrotranscribed RNAs. RNA 5, 618-621, doi:10.1017/s1355838299982328 (1999).

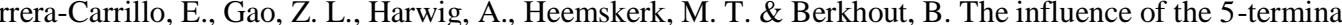
nucleotide on AgoshRNA activity and biogenesis: importance of the polymerase III transcription initiation site. Nucleic Acids Res 45, 4036-4050, doi:10.1093/nar/gkw1203 (2017). Expression of CRISPR gRNAs. PLoS One 11, e0148362, doi:10.1371/journal.pone.0148362 (2016). RNA polymerase using a comprehensive collection of promoter variants. Biochemistry 39, 10419-10430, doi:10.1021/bi000365w (2000). Hwang, W. Y. et al. Heritable and precise zebrafish genome editing using a CRISPR-Cas system. PLoS One $\mathbf{8}$, e68708, doi:10.1371/journal.pone.0068708 (2013). Peeters, B. \& de Leeuw, O. A single-plasmid reverse genetics system for the rescue of non-segmented negativestrand RNA viruses from cloned full-length cDNA. J Virol Methods 248, 187-190, doi:10.1016/j.jviromet.2017.07.008 (2017). Therapy. Methods Mol Biol 1632, 175-186, doi:10.1007/978-1-4939-7138-1_11 (2017). 204, doi:10.1002/humu.1175 (2001).

62 Wang, R., Cotten, S. W. \& Liu, R. mRNA display using covalent coupling of mRNA to translated proteins. Methods Mol Biol 805, 87-100, doi:10.1007/978-1-61779-379-0_6 (2012). 
Luo, M. L., Mullis, A. S., Leenay, R. T. \& Beisel, C. L. Repurposing endogenous type I CRISPR-Cas systems for programmable gene repression. Nucleic Acids Res 43, 674-681, doi:10.1093/nar/gku971 (2015).

Ding, T. et al. Reversed paired-gRNA plasmid cloning strategy for efficient genome editing in Escherichia coli. Microb Cell Fact 19, 63, doi:10.1186/s12934-020-01321-4 (2020). Hawkins, J. S., Wong, S., Peters, J. M., Almeida, R. \& Qi, L. S. Targeted Transcriptional Repression in Bacteria Using CRISPR Interference (CRISPRi). Methods Mol Biol 1311, 349-362, doi:10.1007/978-1-4939-2687-9_23 (2015).

Spencer, J. M. \& Zhang, X. Deep mutational scanning of S. pyogenes Cas9 reveals important functional domains. Sci Rep 7, 16836, doi:10.1038/s41598-017-17081-y (2017).

Liow, L. T., Go, M. D. K. \& Yew, W. S. Characterisation of Constitutive Promoters from the Anderson library in Chromobacterium violaceum ATCC 12472. Engineering Biology 3, 57-66, doi:10.1049/enb.2018.5007 (2019). Nelson, C. E. et al. In vivo genome editing improves muscle function in a mouse model of Duchenne muscular dystrophy. Science 351, 403-407, doi:10.1126/science.aad5143 (2016) Esvelt, K. M. et al. Orthogonal Cas9 proteins for RNA-guided gene regulation and editing. Nat Methods 10, 1116 1121, doi:10.1038/nmeth.2681 (2013).

70 Mashiko, D. et al. Generation of mutant mice by pronuclear injection of circular plasmid expressing Cas 9 and single guided RNA. Sci Rep 3, 3355, doi:10.1038/srep03355 (2013).

71 Jacobus, A. P. \& Gross, J. Optimal cloning of PCR fragments by homologous recombination in Escherichia coli. PLoS One 10, e0119221, doi:10.1371/journal.pone.0119221 (2015). 345, doi:10.1038/nmeth.1318 (2009).

Doench, J. G. et al. Optimized sgRNA design to maximize activity and minimize off-target effects of CRISPRCas9. Nat Biotechnol 34, 184-191, doi:10.1038/nbt.3437 (2016).

Chari, R., Mali, P., Moosburner, M. \& Church, G. M. Unraveling CRISPR-Cas9 genome engineering parameters via a library-on-library approach. Nat Methods 12, 823-826, doi:10.1038/nmeth.3473 (2015). Goomer, R. S. \& Kunkel, G. R. The transcriptional start site for a human U6 small nuclear RNA gene is dictated by a compound promoter element consisting of the PSE and the TATA box. Nucleic Acids Res 20, 4903-4912, doi:10.1093/nar/20.18.4903 (1992).

Kuhn, H. \& Frank-Kamenetskii, M. D. Template-independent ligation of single-stranded DNA by T4 DNA ligase. FEBS J 272, 5991-6000, doi:10.1111/j.1742-4658.2005.04954.x (2005).

Kwok, C. K., Ding, Y., Sherlock, M. E., Assmann, S. M. \& Bevilacqua, P. C. A hybridization-based approach for quantitative and low-bias single-stranded DNA ligation. Anal Biochem 435, 181-186, doi:10.1016/j.ab.2013.01.008 (2013).

Paul, B. \& Montoya, G. CRISPR-Cas12a: Functional overview and applications. Biomed J 43, 8-17, doi:10.1016/j.bj.2019.10.005 (2020).

Kulcsar, P. I. et al. Blackjack mutations improve the on-target activities of increased fidelity variants of SpCas9 with 5'G-extended sgRNAs. Nat Commun 11, 1223, doi:10.1038/s41467-020-15021-5 (2020). Vvedenskaya, I. O. et al. Massively Systematic Transcript End Readout, "MASTER": Transcription Start Site Selection, Transcriptional Slippage, and Transcript Yields. Mol Cell 60, 953-965, doi:10.1016/j.molcel.2015.10.029 (2015). Nepal, C. et al. Dynamic regulation of the transcription initiation landscape at single nucleotide resolution during vertebrate embryogenesis. Genome Res 23, 1938-1950, doi:10.1101/gr.153692.112 (2013). Consortium, F. et al. A promoter-level mammalian expression atlas. Nature 507, 462-470, doi:10.1038/nature13182 (2014).

Chen, R. A. et al. The landscape of RNA polymerase II transcription initiation in C. elegans reveals promoter and enhancer architectures. Genome Res 23, 1339-1347, doi:10.1101/gr.153668.112 (2013). Yamashita, R. et al. Genome-wide characterization of transcriptional start sites in humans by integrative transcriptome analysis. Genome Res 21, 775-789, doi:10.1101/gr.110254.110 (2011). Hoskins, R. A. et al. Genome-wide analysis of promoter architecture in Drosophila melanogaster. Genome Res $\mathbf{2 1}$, 182-192, doi:10.1101/gr.112466.110 (2011). conformational heterogeneity and millisecond-scale dynamics: implications for transcription start-site selection. $J$ Mol Biol 425, 875-885, doi:10.1016/j.jmb.2012.12.015 (2013). 


\section{0. Összefoglalás}

A Streptococcus pyogenes baktériumból származó Cas9 endonukleáz (SpCas9) a génmódosításra jelenleg legelterjedtebben alkalmazott CRISPR/Cas rendszer. A specificitást a guideRNS (gRNS) 5' végén elhelyezkedő 20 bázispáros szekvencia, a spacer biztosítja. A spacer segítségével kerül felismerésre a célszekvencia komplementer DNS-RNS hibridizáció alapján. A nukleáz a DNS mindkét szálát hasítja. Ennek hatására DNS javítási útvonalak indulnak be, melyek a DNS specifikus módosítására használhatók fel. A 2 fő útvonal a homológ rekombinációs (HR) és a nem homológ végcsatlakozás (NHEJ) hibajavítási mechanizmusok. A célszekvencia felismeréséhez és hasításához szükség van egy néhány bázispáros szekvencia jelenlétére is a target mellett, ez a PAM szekvencia. A mai molekuláris biológiai technikákkal már könnyedén változtatható a spacer szekvenciája, ennek köszönhető a rendszer robbanásszerü elterjedése. A Cas9 fehérje segítségével szinte bármilyen genomi szakasz szabadon módosítható, ezért jelentős biotechnológiai, orvosi és tudományos felhasználása van. A Cas12a nukleázokat néhány éve publikálták először, mint genomszerkesztésre alkalmas módszert. Amiatt nagyon érdekesek, mert más PAM szekvenciát ismernek fel, mint az SpCas9, így eltérő targetek hasítására képesek, ráadásul eltérő módon, mert az Cas9-el szemben a DNS két szálának hasításakor nem tompa, hanem ragadós végeket hoznak létre. Azt is megmutatták, hogy alacsonyabb off-target aktivitással bírnak, mint az SpCas9. A CRISPR/Cas rendszereknek vannak limitációi. Az egyik ilyen az off-target hatás, azaz a célszekvenciákhoz hasonló, nem kívánt targetek hasítása. Ennek megoldására számos törekvés van, az egyik ezek közül a nukleáz mutációkkal történő módosítása specifikus helyeken. Napjainkig már több olyan SpCas9 variánst hoztak létre, amelyek megnövekedett specificitással bírnak.

A gRNS-ek előállítására két elterjedt, az RNS szintetizáltatásnál költséghatékonyabb módszer van a gyakorlatban. Az egyik a T7 promóter segítségével történő in vitro RNS transzkripció, a másik a különböző organizmusokban más-más kis RNS expresszióra alkalmas promóterek használata. Számos kutatás szerint a Cas nukleázok müködését befolyásolja a gRNS-ek mennyisége és hossza, ezért rendkívül fontos, hogy pontos ismereteink legyenek az alkalmazott promóterekről. Több tanulmány szerint a promótertől downstream elhelyezkedő nukleotidok befolyásolhatják az RNS expressziót és a transzkripció iniciáció pozícióját is. Bár néhány általunk vizsgált promóter esetében a promótert követő első bázis szerepét már vizsgálták szisztematikusan, de a további nukleotidok szerepét még nem. 
Ezen vizsgálatok alapján a humán 7sk és U6 promóterek egyaránt alkalmazhatók a +1 -es pozícióban A-val és G-vel és a várt hosszúságú RNS-eket kapták róluk.

A T7 promóterről ismert, hogy a promótertől downstream elhelyezkedő első bázis befolyásolja a transzkripció iniciációjának pozícióját, és az eddigi eredmények szerint legalább egy G-t kell használni a megfelelő expresszióhoz. Az azonban az irodalom szerint nem konzisztens, hogy a T7 promóterhez egy, kettő vagy 3 darab guanint szükséges alkalmazni.

Az U6T7 hibrid promótert az U6 promóter módosításával hozták létre, úgy, hogy a promóter végét a $\mathrm{T} 7$ promóterre cserélték le. A hibrid promótert bemutató cikk szerint a +1 -ben legalább egy G-vel ajánlatos használni.

A bakteriális J23119 promóterekkel kapcsolatban tudomásunk szerint eddig nem került publikálásra a +1 -es pozícióval kapcsolatos eredmény.

Habár az U6 és 7sk promóterekről megmutatták, hogy a +1 -es pozícióban A-val is hatékony expresszióra képesek, a gyakorlatban azonban az SpCas9 gRNS-ekhez általában olyan targeteket választanak, amelyekben a spacer 5' első bázisának megfelelő bázis G, amely a targetek számát szükíti. Megoldásképp különböző gRNS módosításokat alkalmaznak, amelyek viszont befolyásolhatják a nukleázok aktivitását.

Ezek a +1-es pozícióra irányuló vizsgálatok általában nem a jelenleg a kis RNS-ek hosszáról és mennyiségéről legpontosabb képet adó újgenerációs szekvenálással (NGS) történtek, hanem egyéb kevésbé pontos módszerekkel, illetve az eddig napvilágot látott NGS-el kapott eredményekhez nagyon kis minta számot alkalmaztak.

Doktori értekezésemben a Cas12a nukleázokkal kapcsolatosan arra kerestük a választ, hogy képesek-e hatékony HR javítás indukálására N2a sejtekben az As-és LbCas12a nukleázok, és mennyire hatékonyak a leggyakrabban alkalmazott Cas9 nukleázokhoz képest.

Összehasonlítottuk az As-, és LbCas12a nukleázok hatékonyságát az Sp- és 3 másik, gyakran alkalmazott Cas9 nukleáz aktivitásával. A nukleázok hasítási aktivitásának vizsgálatához a GFxFP nevü esszét optimalizáltuk egy korábban publikált esszéből, ahol a nukleáz hasítása nélkül is kaptunk háttér fluoreszcens GFP jelet. A riporter esszét sikeresen módosítottam úgy, hogy ez a hasítás nélküli GFP háttér csökkent. Az esszé használatával a különböző PAM szekvenciákból adódó eltérő genomi pozíciók okozta aktivitásbeli különbségeket kívántuk kizárni. Eredményeink alapján bár az SpCas9 hatékonyabbnak bizonyult: nagyobb arányban váltott ki HR javítást a sejtekben, mint a Cas12a-k, de a többi Cas9-el viszont hasonló mértékben, illetve egyes targeteken jobban teljesítettek a Cas12a nukleázok. Nemcsak riporter esszével, de genomi célpontokon is teszteltük a Cas12a nukleázok alkalmasságát 
genomszerkesztésre. Eredményeink szerint alkalmasak HR javítás indukálására genomi targeteket célozva is. A Cas12a nukleázokkal kapcsolatos vizsgálataink során nem a Zetsche és mtsai. által használt emlős sejtekben, hanem más emlős sejteken (N2a) mutattuk be, hogy a Cas12a nukleázok alkalmasak genomszerkesztésre, ráadásul míg ők csak az NHEJ javítási útvonal segítségével tesztelték le aktivitásukat, mi HR javítást indukáltunk a genomban, valamint a GFxFP plazmidot célozva. Eredményeink alapján a Cas12a nukleázok hasznos alternatívát nyújthatnak a genomszerkesztő eszközök palettáján, ami egybecseng azzal, hogy az elmúlt években számos csoport szintén megmutatta alkalmasságukat a génszerkesztésre többféle organizmusban is.

A megnövelt specificitású eSpCas9 és SpCas9HF1 variánsokkal kapcsolatban azt kívántuk megtudni, hogy aktivitásukat hogyan befolyásolják a különböző gRNS módosítások, amelyeket akkor alkalmaznak, ha a targetben a gRNS első átíródó bázisának megfelelő bázis nem guanin. Ezek közül a módosítások közül a gRNS 5' végén elhelyezkedő utolsó nukleotid G-re cserélését, vagy a spacer változatlanul hagyását, továbbá a gRNS-ek 5' végének rövidítését teszteltük le. Hatásukat egy EGFP-t tartalmazó egér neuroblasztóma sejtvonalban, az EGFP hasítás hatékonyságával teszteltük. Eredményeink alapján, míg a vad típusú SpCas9 aktivitását csak kis mértékben befolyásolják ezek a módosítások, addig a nagy specificitású Cas9 variánsok aktivitását különböző mértékben, de jobban rontják. Így eredményeink alapján e nukleáz variánsokat ilyen módosításokkal nem lehet rutinszerüen alkalmazni. Ennek feloldására többféle megoldás is lehetséges, az egyik a nukleáz variánsok olyan további mutációkkal történő módosítása, amely által jobban tolerálják a gRNS módosításait. A megnövelt specificitású nukleázok targeteinek körét bővítendő felmerül az igény a kis RNS expresszióra alkalmas promóterek mélyrehatóbb vizsgálatára. Ennek segítségével lehetne olyan egyéb szekvenciákat találni, amelyekkel gRNS módosítások nélkül is használhatóak lennének ezek a nukleázok.

A disszertációmban bemutatott munka nagyobbik részében arra kerestünk választ, hogy a gRNS-ekhez gyakran alkalmazott promótereknél a promótertől downstream elhelyezkedő bázisok milyen módon befolyásolják az RNS expressziót és a kezdő szekvenciákat.

A doktori értekezésem alapjául szolgáló kísérleteinkben a kiválasztott promóterek sokkal átfogóbb vizsgálatát végeztük el az eddigiekhez képest. Nemcsak a +1 -es pozíció, de a tőle downstream elhelyezkedő további 3 pozíció szerepét is megvizsgáltuk az RNS mennyiségekre és a transzkripció iniciációs pozíciókra. Kutatásunkban minden promóterhez plazmid 
könyvtárakat hoztunk létre, és a plazmid könyvtárakról expresszálódott RNS-ek szekvenálásához egy egyedi, gRNS-ek szekvenálására alkalmas módszert alkalmaztunk. Kísérleteinket az RNS-t kódoló szakaszba épített randomizált bárkódoknak köszönhetően rengeteg különböző RNS szekvenciával végeztük el, amellyel a vizsgált 4 bázisos szekvencia különbségein kívül adódó külső hatásokat, mint például szekvenciaspecifikus RNS degradáció, kívántuk elkerülni. A promóterekre irányuló vizsgálatainkat 4 bázispáros szekvenciánként nagy lefedettséggel végeztük el a legmodernebb technikák közé tartozó újgenerációs szekvenálás segítségével.

Az NGS eredményeink alapján az összes vizsgált promóterre igaz, hogy a promótertől downstream lévő pozíciók nukleotidjai befolyásolhatják a keletkező RNS-ek mennyiségét és a transzkripció iniciációjának pontos helyét, ezáltal az RNS hosszát is. Eddig csak a +1-es pozíciót vizsgálták szisztematikusan, azt is csak a T7, U6 és 7sk promóterek esetében. Eredményeink alapján nemcsak a +1 pozíció, de a tőle downstream lévő pozíciók is fontosak az RNS expresszió szempontjából. Így előfordulhat, hogy nagyságrendbeli különbségek lehetnek az RNS mennyiségekben a további pozíciók függvényében, hiába azonos a +1 -es pozíció nukleotidja.

Azt találtuk, hogy az összes vizsgált promóternél befolyásolhatja a transzkripció kezdő pozícióját is a promótertől downstream elhelyezkedő szekvencia. Mindegyik promóternél azt kaptuk, hogy ha a promótertől downstream az első pozícióban pirimidin van, sokkal kisebb arányban lesz a +1 -es pozíció a kezdő pozíció, és ilyenkor nem egy fix pozícióról indul el az átírás. Abban az esetben, ha a +1-ben pirimidin van, mindegyik promóter esetében nagymértékben befolyásolta nemcsak a promótert követő első, hanem a többi azt követő nukleotid is, hogy melyik kezdő pozícióról milyen arányban indult el az átírás.

Megmutattuk, hogy a humán U6 promóterről expresszálódó RNS-ek mennyiségében a +1A és a +1G között nincs szignifikáns különbség, ami egybecseng azokkal a publikációkkal, amelyek szerint az U6 promóter $+1 \mathrm{~A}$-val is használható. Ha a +1 pozícióban $\mathrm{A}$, vagy $\mathrm{G}$ nukleotid van, a transzkripció kezdő pozíciója közel minden esetben a +1 , melyet jelentős módon már nem befolyásol a $+2-+4$ pozíciók szekvenciája.

Azt találtuk, hogy a humán 7sk promóter szintén nemcsak +1 guaninnal, hanem adeninnal is használható kis RNS expresszióra. A 7sk promóternél a +1 -es pozícióban a purin jelenléte pontos, +1 pozíciójú transzkripciós iniciációt okoz, amin a további $+2-+4$. pozíciók szekvenciája jelentősen nem változtat. $+1 \mathrm{G}$-vel szignifikánsan több RNS keletkezik, mint +1Aval. Azt találtuk, hogy HEK sejtekben az U6 és a 7sk promóterekről termelődött RNS-ek 
mennyiségében nincs szignifikáns különbség, így a 7sk párhuzamosan, vagy akár az U6 promóter helyett is alkalmas lehet gRNS expresszióra.

A T7 promóter a méréseink szerint az eddigi adatokkal megegyezően a +1 -es pozícióban a guanint preferálja. Vannak azonban olyan adeninnel kezdődő szekvenciák is, amelyek megközelítik a +1G-ről termelődő RNS-ek mennyiségét és az átírás is nagyrészt +1 -ről indul el. Eredményeink szerint a +1-ben G-t tartalmazó szekvenciák közül a GG és GGG kezdetűekről kevesebb transzkript keletkezik, mint a nagyobb expressziót biztosító GA kezdetüekröl.

Eredményeink alapján a módosított hibrid U6T7 promóter, bár T7 polimerázzal jól használható, emlős expresszióhoz figyelembe kell venni, hogy bár azt találtuk, hogy az U6T7, a 7sk és az U6 promóterekről keletkezett RNS-ek mennyiségében nincs szignifikáns különbség, de nagyon heterogén hosszúságú RNS-ek keletkeznek róla, még +1purinról is.

Megvizsgáltuk a J23119 promótertől downstream elhelyezkedő szekvencia hatását a transzkripcióra, és azt találtuk, hogy ha a +1 -es pozícióban purin van, a transzkripció iniciáció helye majdnem mindig a +1 -es pozíció, amit a $+2-+4$ pozíciók szekvenciája már nem befolyásol jelentős mértékben. Továbbá megmutattuk, hogy a legtöbb RNS akkor keletkezik, ha a +1 -ben purin van.

A promóterekkel kapcsolatos eredményeink több okból is jelentősek lehetnek.

A 3 különböző organizmusból származó promóterek mindegyikénél azt találtuk, hogy a promótertől downstream nemcsak az első, hanem további 3 pozíció is befolyásolja a transzkripció iniciációs pozíciót, ezáltal az RNS-ek hosszát, valamint az expressziót is. Ez az alapkutatásban is érdekes lehet és felveti más promóterek, illetve további pozíciók vizsgálatának szükségszerüségét.

Eredményeink alapján a vizsgált promóterekkel adott szekvenciákat alkalmazva nagyobb RNS szint és pontosabb hosszúságú RNS-ek érhetőek el. Ez rendkívül hasznos lehet különböző alkalmazások számára, mint például az RNS interferencia, vagy a CRISPR. Eredményeink alapján a CRISPR-hez választható targetek köre bővülhet, abból adódóan, hogy találtunk olyan a promóterektől dowsntream elhelyezkedő szekvenciákat, amelyekről eddig nem volt ismert, hogy ugyanolyan alkalmasak lehetnek gRNS expresszióra, mint az eddig ismert variációk. Eredményeink ezen kívül- akár további pozíciók vizsgálatából származó eredményekkel együtt- alkalmasak lehetnének a jelenlegi CRISPR target predikciós programok továbbfejlesztéséhez is.

A disszertációmban bemutatott eredmények hozzájárulhatnak a CRISPR/Cas rendszer hatékonyabb alkalmazásához. 


\section{Summary}

The Cas9 endonuclease (SpCas9) from the bacteria Streptococcus pyogenes is currently the most widely applied CRISPR/Cas system used for genetic engineering. Its specificity is provided by the $20 \mathrm{bp}$ 'spacer' sequence at the 5 'end of the guideRNA (gRNA). The spacer is used to identify the target sequence based on complementary DNA-RNA hybridization. Nuclease cleaves both strands of DNA. This triggers DNA repair pathways that can be used to specifically modify DNA. The 2 main pathways are homologous recombination (HR) and nonhomologous end joining (NHEJ) error correction mechanisms. Recognition and cleavage of the target sequence also requires the presence of a few base pairs in addition to the target, the PAM sequence. With today's molecular biology techniques, the sequence of the spacer can be easily changed, thanks to which the system has explosively spread. Almost any section of the genome can be freely modified with the Cas9 protein, so it has significant biotechnological, medical and scientific uses.

Cas12a nucleases were first published a few years ago as a method for genome editing. They are very interesting because they recognize a different PAM sequence than SpCas9, so they are able to cleave different targets, and in a different way, because in contrast to Cas9, cleavage of two strands of DNA creates sticky ends rather than blunt ones. They have also been shown to have lower off-target activity than SpCas9. CRISPR/Cas systems have limitations. One of these is the off-target effect, i.e. the cleavage of unwanted targets similar to the target sequences. There were several attempts to address this, one of which is to modify the nuclease with mutations at specific sites. To date, several SpCas9 variants have been developed that have increased specificity.

There are two common methods for producing gRNAs in practice than the more cost-effective RNA synthesis. One is using the T7 promoter in vitro for RNA transcription, and the other is the use of promoters suitable small RNA expression in different organisms. Numerous studies have shown that the activity of Cas nucleases is influenced by the amount and length of gRNAs, so it is extremely important to have an accurate knowledge of the promoters used.

Several studies suggest that nucleotides downstream of the promoter can also affect RNA expression and the position of transcription initiation. Although for some of the promoters we studied, the role of the first nucleotide downstream of the promoter has already been systematically investigated, but the role of additional nucleotides has not yet been studied. 
Based on these studies, both the human 7sk and U6 promoters can be used with A and G at the +1 position, and RNAs with the expected length were obtained from them.

The transcriptional start site of the $\mathrm{T} 7$ promoter is known to be affected by the first nucleotide downstream of the promoter and several results suggest that at least one Guanine should be used for proper expression. However, it is not consistent in the literature that the T7 promoter requires one, two or 3 guanines.

The U6T7 hybrid promoter was created by modifying the U6 promoter by replacing the end of the promoter with the $\mathrm{T} 7$ promoter.

According to the article introducing the hybrid promoter, it is recommended to use at least one $\mathrm{G}$ nucleotide. To the best of our knowledge, no result for the +1 position has been published for bacterial $\mathrm{J} 23119$ promoters.

Although the U6 and 7sk promoters have been shown to be efficient in expressing RNAs with an $\mathrm{A}$ at position +1 , in practice targets for SpCas9 gRNAs are generally selected in which the base corresponding to the 5 ' first base of the spacer is $\mathrm{G}$, which narrows the number of the potential targets. As a solution, various gRNA modifications are used, which in turn can affect the activity of nucleases.

These +1 position studies were generally not performed with next-generation sequencing (NGS), which currently provides the most accurate picture of the length and amount of small RNAs, but with other less accurate methods and the results obtained with NGS so far used a very small sample size.

With regard to Cas12a nucleases we were looking for answers to their ability to effectively induce HR repair in N2A cells, and to their efficiency compared to the most commonly used Cas9 nucleases.We compared the efficacy of As and LbCas12a nucleases with the activity of Sp- and 3 other commonly used Cas 9 nucleases. To examine the cleavage activity of nucleases, an assay called GFxFP was optimized from a previously published assay in which a background fluorescent GFP signal was obtained without cleavage of the nuclease. We successfully modified the reporter essay to reduce this non-cleaved GFP background. Using the assay, we wanted to exclude differences in activity caused by different genomic positions due to different PAM sequences. Based on our results, although SpCas9 proved to be more effective: it elicited a higher rate of HR improvement in cells than Cas12a, but compared to other Cas9s, Cas12a nucleases performed to a similar extent at some targets. We tested the suitability of Cas12a nucleases for genome editing not only with a reporter assay but also with genomic targets. 
Our results suggest that they are also suitable for inducing HR repair by targeting genomic targets. In our studies of Cas12a nucleases, we used another mammalian cell line (N2a) than Zetsche et al., and demonstrated that Cas12a nucleases are suitable for genome engineering, and while they only tested their activity using the NHEJ repair pathway, we induced HR repair in the genome and we targeted the GFxFP plasmid as well. Based on our results, Cas12a nucleases may provide a useful alternative in the range of genome editing tools, which is consistent with the fact that in recent years, several groups have also shown their suitability for gene editing in a variety of organisms.

In connection with the eSpCas9 and SpCas9HF1 variants with increased specificity, we wanted to know how their activity is affected by the different gRNA modifications used when the base corresponding to the first transcribed base of gRNA in the target is not guanine. Of these modifications, the replacement of the last nucleotide at the 5 'end of the gRNA with G, or leaving the spacer unchanged, and the shortening of the 5' end of the gRNAs were tested. Their effects were tested in an EGFP-containing mouse neuroblastoma cell line with the efficacy of EGFP cleavage. Based on our results, while the activity of wild-type SpCas9 is only slightly affected by these modifications, the activity of the high-specificity Cas 9 variants is greatly reduced to varying degrees. Thus, based on our results, these nuclease variants cannot be routinely used with such modifications. Several solutions are possible to resolve this, one of which is to modify the nuclease variants with additional mutations that better tolerate the modifications of the gRNA. In order to expand the range of targets for nucleases with increased specificity, there is a need for a more detailed study of promoters suitable for small RNA expression. This could be used to find other sequences with which these nucleases could be used without gRNA modifications.

In most of the work presented in my dissertation, we sought to answer the question of how bases located downstream of the promoters commonly used to express gRNAs are to affect RNA expression and the transcription start positions. In our experiments we performed a much more comprehensive examination of the selected promoters than others before. The role of not only the +1 position but also the 3 additional positions downstream of it was examined for RNA amounts and transcription initiation positions. In our study, plasmid libraries were generated for each promoter and a unique method for sequencing gRNAs was used to sequence RNAs expressed from plasmid libraries. 
Our experiments were performed with a large number of different RNA sequences, thanks to randomized barcodes built into the RNA coding region, in order to avoid external effects such as sequence-specific RNA degradation in addition to the 4 base sequence differences studied. Our studies of promoters were performed with high coverage per 4 basepair long sequences using next generation sequencing which is a state-of-the-art technique.

Based on our NGS results, it is true for all investigated promoters that the nucleotides of positions downstream of the promoter can affect the amount of RNA generated and the exact location of transcription initiation, and thus the length of the RNA. So far, only the +1 position has been systematically examined, also only for the T7, U6, and 7sk promoters. Based on our results, not only the +1 position but also the positions downstream of it are important for RNA expression. Thus, there may be orders of magnitude differences in RNA amounts depending on the additional positions, even though the nucleotide at position +1 is the same. It has been found for all promoters tested, that the starting position of transcription may also be affected by a sequence downstream of the promoter. For each promoter, we found that if pyrimidine is in the first position downstream of the promoter, the +1 position will be the starting position in a much smaller proportion, and in this case the transcription will not start from a fixed position. In the case of pyrimidine in +1 , the starting position rate of each promoter was greatly influenced not only by the first nucleotide following the promoter but also by the other subsequent nucleotides.

We found that there was no significant difference in the amount of RNA expressed from the human $\mathrm{U} 6$ promoter between $+1 \mathrm{~A}$ and $+1 \mathrm{G}$, which is consistent with publications that the U6 promoter can also be used with an A. Examination of transcripts transcribed from the U6 promoter showed that if there is an $A$ or $G$ nucleotide at position +1 , the starting position of transcription is in almost all cases the +1 , which is not much affected by $+2-4$ positions.

We found that the human 7 sk promoter can also be used not only with +1 guanine but also with adenine for small RNA expression. We have shown that the presence of purine at the +1 position causes accurate transcription initiation at the +1 position, and the additional $+2-+4$ positions does not change this significantly. $+1 \mathrm{G}$ produces significantly more RNA than $+1 \mathrm{~A}$. We have found that there is no significant difference in the amount of RNA produced from the U6 and 7sk promoters in HEK-293 cells, so the 7sk may be suitable for gRNA expression in parallel or even in place of the U6 promoter. 
According to our measurements, the $\mathrm{T} 7$ promoter prefers guanine at the +1 position, similar to the previous data. However, there are also sequences starting with adenine from which the same amount of RNAs can be produced like with $+1 \mathrm{G}$, and transcription also largely starts from +1 . According to our results, GG and GGG sequences generate half and a quarter amount of transcripts, respectively, than those initiating with GA.

Based on our results, the modified U6T7 hybrid promoter, although useful with T7 polymerase, should be considered for mammalian expression. Although we found that there was no significant difference in the amount of RNA generated from the U6T7, 7sk, and U6 promoters, but RNAs form U6T7 promoter are very heterogeneous in length, even from +1 purine.

We examined the effect of the sequence downstream of the J23119 promoter on transcription and found that for +1 purine, the site of transcription initiation is almost always the +1 position, which is not significantly affected by $+2-4$. positions. Furthermore, we have shown that most RNA is generated when purine is present in +1 .

Our results related to promoters can be significant for several reasons.

For each of the promoters from 3 different organisms we found that not only the first but also the 3 additional positions downstream of the promoter can affect the transcription start site, and thus the length of the RNAs as well as the expression. This may also be interesting in basic research and raises the need for other promoters and additional positions.

Based on our results, higher RNA levels and more accurate lengths of RNAs can be obtained using the sequences provided with the promoters studied. This can be extremely useful for various applications such as RNA interference or CRISPR. Based on our results, the range of targets that can be selected for CRISPR may be expanded due to the finding of downstreamlocated sequences from promoters that were not previously known to be as suitable for gRNA expression as previously known variations. In addition, our results- together with the results from the examination of additional positions- could be suitable for the further development of the current CRISPR target prediction programs.

The results presented in my dissertation can contribute to a more efficient application of the CRISPR/Cas system. 


\section{Publikációs lista}

A disszertáció témájához közvetlenül kapcsolódó közlemények:

1. Cpf1 nucleases demonstrate robust activity to induce DNA modification by exploiting homology directed repair pathways in mammalian cells

Toth, E; Weinhardt, N*; Bencsura, P; Huszar, K; Kulcsar, P I; Talas, A; Fodor, E; Welker, E BIOLOGY DIRECT 11 Paper: 46, 14 p. (2016) IF:3,472 *megosztott első szerző

2. Crossing enhanced and high fidelity SpCas9 nucleases to optimize specificity and cleavage Kulcsar, PI; Talas, A; Huszar, K; Ligeti, Z; Toth, E; Weinhardt, N; Fodor, E; Welker, E GENOME BIOLOGY 18 Paper: 190, 17 p. (2017) IF:13,214

3. Nucleotides downstream of the promoter affect start site and RNA level in promoters used for gRNA expression

(Az eredmények jelenleg kézirat formájában vannak, melynek a jelölt az első szerzője)

A disszertáció témájához közvetlenül kapcsolódó közlemények kumulatív hatástényezője: 16,686

A disszertáció témájához közvetve kapcsolódó közlemények:

4. $\mathrm{Mb}$ - and FnCpf1 nucleases are active in mammalian cells: activities and PAM preferences of four wild-type Cpf1 nucleases and of their altered PAM specificity variants.

Toth, E; Czene, B C; Kulcsar, P I; Krausz, S L; Talas, A; Nyeste, A; Varga, E; Huszar, K; Weinhardt, N; Ligeti, Z; Borsy A; Fodor, E; Welker, E

NUCLEIC ACIDS RESEARCH 46: 19 pp. 10272-10285., 14 p. (2018) IF:11,147

5. A convenient method to pre-screen candidate guide RNAs for CRISPR/Cas9 gene editing by NHEJ-mediated integration of a 'self-cleaving' GFP-expression plasmid

Talas, A; Kulcsar, P I; Weinhardt, N; Borsy, A; Toth, E; Szebenyi, K; Krausz, S L; Huszar, K; Vida, I; Sturm, A; Gordos, B; Hoffmann, O I; Bencsura, P; Nyeste, A; Ligeti, Z; Fodor, E; Welker, E

DNA RESEARCH 24: 6 pp. 609-621., 13 p. (2017) IF:5,415

A disszertáció témájához nem kapcsolódó közlemények:

6. Highly efficient RNAi and Cas9-based auto-cloning systems for C. elegans research. Sturm, A; Saskoi, E; Kovacs, T; Weinhardt, N; Vellai, T

NUCLEIC ACIDS RESEARCH 46: 17 Paper: e105, 13 p. (2018) IF:11,147

MTMT azonosító: 10054747

Összes publikáció kumulatív hatástényezője (IF): 44,395

Összes független hivatkozások száma: 97

Hirsch index: 5 


\section{Függelék}

U6 promóter eredményeihez kapcsolódó p értékek

$(0,000$ jelentése $<0,001)$

24. ábra

\begin{tabular}{|ccc|}
\hline$A$ & $C$ & 0,000 \\
& $G$ & 1,000 \\
& $T$ & 0,000 \\
C & $A$ & 0,000 \\
G & 0,000 \\
T & 0,990 \\
G & A & 1,000 \\
C & 0,000 \\
T & 0,000 \\
T & A & 0,000 \\
C & 0,990 \\
G & 0,000 \\
\hline
\end{tabular}

25. ábra

\begin{tabular}{|c|c|c|c|c|c|c|c|c|}
\hline \multirow[t]{15}{*}{$A A$} & $A C$ & $1,000 \mathrm{CA}$ & AA & $0,510 \mathrm{GA}$ & AA & $1,000 \mathrm{TA}$ & AA & 1,000 \\
\hline & AG & 0,000 & AC & 0,542 & AC & 1,000 & $A C$ & 1,000 \\
\hline & AT & 0,511 & AG & 0,000 & AG & 0,000 & AG & 0,000 \\
\hline & $\mathrm{CA}$ & 0,510 & AT & 0,000 & AT & 0,732 & AT & 0,523 \\
\hline & CC & 0,000 & CC & 0,000 & $\mathrm{CA}$ & 0,303 & CA & 0,498 \\
\hline & CG & 1,000 & CG & 0,747 & $\mathrm{CC}$ & 0,000 & CC & 0,000 \\
\hline & CT & 0,000 & CT & 0,000 & CG & 1,000 & CG & 1,000 \\
\hline & GA & 1,000 & GA & 0,303 & CT & 0,000 & CT & 0,000 \\
\hline & GC & 0,789 & GC & 1,000 & GC & 0,577 & GA & 1,000 \\
\hline & GG & 0,000 & GG & 0,000 & GG & 0,000 & GC & 0,779 \\
\hline & GT & 0,003 & GT & 0,000 & GT & 0,008 & GG & 0,000 \\
\hline & TA & 1,000 & TA & 0,498 & TA & 1,000 & GT & 0,003 \\
\hline & TC & 0,000 & TC & 0,000 & TC & 0,000 & TC & 0,000 \\
\hline & TG & 1,000 & TG & 0,350 & TG & 1,000 & TG & 1,000 \\
\hline & $\pi$ & 0,000 & $\pi$ & 0,000 & $\pi$ & 0,000 & $\pi$ & 0,000 \\
\hline \multirow[t]{15}{*}{$A C$} & AA & $1,000 \mathrm{CC}$ & $A A$ & $0,000 \mathrm{GC}$ & AA & 0,789 TC & AA & 0,000 \\
\hline & AG & 0,000 & $A C$ & 0,000 & $A C$ & 0,815 & $A C$ & 0,000 \\
\hline & AT & 0,479 & $A G$ & 0,000 & $A G$ & 0,000 & AG & 0,000 \\
\hline & CA & 0,542 & AT & 0,000 & AT & 0,002 & AT & 0,000 \\
\hline & $\mathrm{CC}$ & 0,000 & CA & 0,000 & $\mathrm{CA}$ & 1,000 & $\mathrm{CA}$ & 0,000 \\
\hline & CG & 1,000 & CG & 0,000 & CC & 0,000 & CC & 0,999 \\
\hline & CT & 0,000 & CT & 0,999 & CG & 0,938 & CG & 0,000 \\
\hline & GA & 1,000 & GA & 0,000 & CT & 0,000 & CT & 0,639 \\
\hline & GC & 0,815 & GC & 0,000 & GA & 0,577 & GA & 0,000 \\
\hline & GG & 0,000 & GG & 0,000 & GG & 0,000 & GC & 0,000 \\
\hline & GT & 0,002 & GT & 0,000 & GT & 0,000 & GG & 0,000 \\
\hline & TA & 1,000 & TA & 0,000 & TA & 0,779 & GT & 0,000 \\
\hline & TC & 0,000 & TC & 0,999 & TC & 0,000 & TA & 0,000 \\
\hline & TG & 1,000 & TG & 0,000 & TG & 0,634 & TG & 0,000 \\
\hline & $\pi$ & 0,000 & $\pi$ & 1,000 & $\pi$ & 0,000 & $\pi$ & 1,000 \\
\hline \multirow[t]{15}{*}{ AG } & $A A$ & $0,000 \mathrm{CG}$ & $A A$ & $1,000 \mathrm{GG}$ & AA & $0,000 \mathrm{TG}$ & AA & 1,000 \\
\hline & $A C$ & 0,000 & $A C$ & 1,000 & $A C$ & 0,000 & $A C$ & 1,000 \\
\hline & AT & 0,000 & AG & 0,000 & $A G$ & 1,000 & $A G$ & 0,000 \\
\hline & CA & 0,000 & AT & 0,289 & AT & 0,000 & AT & 0,679 \\
\hline & CC & 0,000 & CA & 0,747 & CA & 0,000 & $\mathrm{CA}$ & 0,350 \\
\hline & CG & 0,000 & $\mathrm{CC}$ & 0,000 & $\mathrm{CC}$ & 0,000 & $\mathrm{CC}$ & 0,000 \\
\hline & CT & 0,000 & CT & 0,000 & $\mathrm{CG}$ & 0,000 & CG & 1,000 \\
\hline & GA & 0,000 & GA & 1,000 & CT & 0,000 & CT & 0,000 \\
\hline & GC & 0,000 & GC & 0,938 & GA & 0,000 & GA & 1,000 \\
\hline & GG & 1,000 & GG & 0,000 & GC & 0,000 & GC & 0,634 \\
\hline & GT & 0,000 & GT & 0,001 & GT & 0,000 & GG & 0,000 \\
\hline & TA & 0,000 & TA & 1,000 & TA & 0,000 & GT & 0,006 \\
\hline & TC & 0,000 & TC & 0,000 & TC & 0,000 & TA & 1,000 \\
\hline & TG & 0,000 & TG & 1,000 & TG & 0,000 & $\mathrm{TC}$ & 0,000 \\
\hline & $\pi$ & 0,000 & $\pi$ & 0,000 & $\pi$ & 0,000 & $\pi$ & 0,000 \\
\hline \multirow[t]{15}{*}{ AT } & AA & $0,511 \mathrm{CT}$ & AA & $0,000 \mathrm{GT}$ & AA & $0,003 \pi$ & AA & 0,000 \\
\hline & $A C$ & 0,479 & $A C$ & 0,000 & $A C$ & 0,002 & $A C$ & 0,000 \\
\hline & AG & 0,000 & AG & 0,000 & $A G$ & 0,000 & AG & 0,000 \\
\hline & $\mathrm{CA}$ & 0,000 & AT & 0,000 & AT & 0,855 & AT & 0,000 \\
\hline & CC & 0,000 & CA & 0,000 & CA & 0,000 & $\mathrm{CA}$ & 0,000 \\
\hline & CG & 0,289 & $\mathrm{CC}$ & 0,999 & $\mathrm{CC}$ & 0,000 & $\mathrm{CC}$ & 1,000 \\
\hline & CT & 0,000 & CG & 0,000 & CG & 0,001 & CG & 0,000 \\
\hline & GA & 0,732 & GA & 0,000 & CT & 0,000 & CT & 0,983 \\
\hline & C & 0,002 & GC & 0,000 & GA & 0,008 & GA & 0,000 \\
\hline & GG & 0,000 & GG & 0,000 & GC & 0,000 & GC & 0,000 \\
\hline & GT & 0,855 & GT & 0,000 & GG & 0,000 & GG & 0,000 \\
\hline & TA & 0,523 & TA & 0,000 & TA & 0,003 & GT & 0,000 \\
\hline & TC & 0,000 & TC & 0,639 & TC & 0,000 & TA & 0,000 \\
\hline & TG & 0,679 & TG & 0,000 & TG & 0,006 & TC & 1,000 \\
\hline & $\pi$ & 0,000 & $\pi$ & 0,983 & $\pi$ & 0,000 & TG & 0,000 \\
\hline
\end{tabular}


26. ábra

\begin{tabular}{|c|c|c|c|c|c|c|c|c|c|c|c|c|c|c|c|c|}
\hline \multirow[t]{31}{*}{ AAA } & AAC & $0,619 \mathrm{AAG}$ & AAA & 0,431 ACA & AAA & 0,604 ACG & AAA & 0,657 AGA & AAA & 0,000 AGG & AAA & 0,002 ATA & AAA & 0,262 ATG & AAA & 0,132 \\
\hline & AAG & 0,431 & AAC & 0,973 & AAC & 1,000 & AAC & 1,000 & AAC & 0,000 & AAC & 0,013 & AAC & 0,827 & AAC & 0,756 \\
\hline & AAT & 0,122 & AAT & 1,000 & AAG & 1,000 & AAG & 1,000 & AAG & 0,823 & AAG & 0,159 & AAG & 1,000 & AAG & 1,000 \\
\hline & ACA & 0,604 & $\mathrm{ACA}$ & 1,000 & AAT & 1,000 & AAT & 1,000 & AAT & 0,049 & AAT & 0,040 & AAT & 1,000 & AAT & 1,000 \\
\hline & ACC & 0,887 & ACC & 0,980 & $\mathrm{ACC}$ & 1,000 & ACA & 1,000 & ACA & 0,019 & ACA & 0,018 & ACA & 0,987 & ACA & 0,996 \\
\hline & ACG & 0,657 & ACG & 1,000 & ACG & 1,000 & $\mathrm{ACC}$ & 1,000 & ACC & 0,002 & $\mathrm{ACC}$ & 0,010 & ACC & 0,851 & $\mathrm{ACC}$ & 0,829 \\
\hline & ACT & 0,937 & ACT & 0,991 & ACT & 1,000 & ACT & 1,000 & ACG & 0,242 & ACG & 0,041 & ACG & 1,000 & ACG & 1,000 \\
\hline & AGA & 0,000 & AGA & 0,823 & AGA & 0,019 & AGA & 0,242 & ACT & 0,008 & $\mathrm{ACT}$ & 0,010 & ACT & 0,903 & ACT & 0,912 \\
\hline & AGC & 0,394 & AGC & 0,994 & AGC & 0,845 & AGC & 0,935 & AGC & 1,000 & AGA & 0,654 & AGA & 0,988 & AGA & 0,550 \\
\hline & AGG & 0,002 & AGG & 0,159 & AGG & 0,018 & AGG & 0,041 & AGG & 0,654 & AGC & 1,000 & AGC & 1,000 & AGC & 0,992 \\
\hline & AGT & 0,000 & AGT & 0,095 & AGT & 0,001 & AGT & 0,010 & AGT & 0,367 & AGT & 1,000 & AGG & 0,330 & AGG & 0,097 \\
\hline & ATA & 0,262 & ATA & 1,000 & ATA & 0,987 & ATA & 1,000 & ATA & 0,988 & ATA & 0,330 & AGT & 0,249 & AGT & 0,020 \\
\hline & ATC & 0,067 & ATC & 1,000 & ATC & 0,999 & ATC & 1,000 & ATC & 0,049 & ATC & 0,048 & ATC & 1,000 & ATA & 1,000 \\
\hline & ATG & 0,132 & ATG & 1,000 & ATG & 0,996 & ATG & 1,000 & ATG & 0,550 & ATG & 0,097 & ATG & 1,000 & ATC & 1,000 \\
\hline & ATT & 0,323 & ATा & 1,000 & AT & 1,000 & ATा & 1,000 & ATा & 0,168 & АाT & 0,042 & AT & 1,000 & АाT & 1,000 \\
\hline & GAA & 0,513 & GAA & 0,995 & GAA & 1,000 & GAA & 1,000 & GAA & 0,001 & GAA & 0,015 & GAA & 0,914 & GAA & 0,905 \\
\hline & GAC & 0,898 & GAC & 0,898 & GAC & 0,999 & GAC & 0,996 & GAC & 0,000 & GAC & 0,009 & GAC & 0,686 & GAC & 0,545 \\
\hline & GAG & 0,019 & GAG & 1,000 & GAG & 0,865 & GAG & 0,999 & GAG & 0,303 & GAG & 0,095 & GAG & 1,000 & GAG & 1,000 \\
\hline & GAT & 0,929 & GAT & 0,997 & GAT & 1,000 & GAT & 1,000 & GAT & 0,019 & GAT & 0,012 & GAT & 0,943 & GAT & 0,961 \\
\hline & GCA & 0,568 & GCA & 0,986 & GCA & 1,000 & GCA & 1,000 & GCA & 0,001 & GCA & 0,014 & GCA & 0,872 & GCA & 0,834 \\
\hline & GCC & 1,000 & GCC & 0,387 & GCC & 0,574 & GCC & 0,604 & GCC & 0,001 & GCC & 0,001 & GCC & 0,231 & GCC & 0,133 \\
\hline & GCG & 0,309 & GCG & 1,000 & GCG & 1,000 & GCG & 1,000 & GCG & 0,002 & GCG & 0,020 & GCG & 0,971 & GCG & 0,981 \\
\hline & GCT & 1,000 & GCT & 0,359 & GCT & 0,490 & GCT & 0,557 & GCT & 0,000 & GCT & 0,002 & GCT & 0,214 & GCT & 0,101 \\
\hline & GGA & 0,001 & GGA & 0,851 & GGA & 0,020 & GGA & 0,264 & GGA & 1,000 & GGA & 0,497 & GGA & 0,994 & GGA & 0,562 \\
\hline & GGC & 0,052 & GGC & 0,989 & GGC & 0,466 & GGC & 0,768 & GGC & 1,000 & GGC & 0,941 & GGC & 1,000 & GGC & 0,971 \\
\hline & GGG & 0,005 & GGG & 0,085 & GGG & 0,025 & GGG & 0,036 & GGG & 0,347 & GGG & 1,000 & GGG & 0,152 & GGG & 0,071 \\
\hline & GGT & 0,003 & GGT & 0,531 & GGT & 0,051 & GGT & 0,154 & GGT & 0,998 & GGT & 1,000 & GGT & 0,821 & GGT & 0,356 \\
\hline & GTA & 0,000 & GTA & 0,675 & GTA & 0,010 & GTA & 0,157 & GTA & 1,000 & GTA & 0,659 & GTA & 0,948 & GTA & 0,333 \\
\hline & GTC & 0,142 & GTC & 1,000 & GTC & 1,000 & GTC & 1,000 & GTC & 0,005 & GTC & 0,029 & GTC & 0,997 & GTC & 1,000 \\
\hline & GTG & 0,000 & GTG & 0,916 & GTG & 0,033 & GTG & 0,344 & GTG & 1,000 & GTG & 0,524 & GTG & 0,998 & GTG & 0,722 \\
\hline & GT & 0,198 & GTT & 1,000 & GT & 0,994 & GT & 1,000 & GT & 0,842 & GTा & 0,162 & GTT & 1,000 & GT & 1,000 \\
\hline \multirow[t]{31}{*}{ AAC } & AAA & 0,619 AAT & AAA & $0,122 \mathrm{ACC}$ & AAA & $0,887 \mathrm{ACT}$ & AAA & 0,937 AGC & AAA & 0,394 AGT & AAA & 0,000 ATC & AAA & 0,067 ATT & AAA & 0,323 \\
\hline & AAG & 0,973 & AAC & 0,845 & AAC & 1,000 & AAC & 1,000 & AAC & 0,721 & AAC & 0,000 & AAC & 0,567 & AAC & 0,989 \\
\hline & AAT & 0,845 & AAG & 1,000 & AAG & 0,980 & AAG & 0,991 & AAG & 0,994 & AAG & 0,095 & AAG & 1,000 & AAG & 1,000 \\
\hline & ACA & 1,000 & ACA & 1,000 & AAT & 0,936 & AAT & 0,982 & AAT & 0,947 & AAT & 0,002 & AAT & 1,000 & AAT & 1,000 \\
\hline & $\mathrm{ACC}$ & 1,000 & $\mathrm{ACC}$ & 0,936 & $\mathrm{ACA}$ & 1,000 & ACA & 1,000 & ACA & 0,845 & ACA & 0,001 & ACA & 0,999 & ACA & 1,000 \\
\hline & ACG & 1,000 & ACG & 1,000 & ACG & 1,000 & $\mathrm{ACC}$ & 1,000 & $\mathrm{ACC}$ & 0,717 & $\mathrm{ACC}$ & 0,000 & ACC & 0,783 & $\mathrm{ACC}$ & 0,995 \\
\hline & ACT & 1,000 & ACT & 0,982 & ACT & 1,000 & ACG & 1,000 & ACG & 0,935 & ACG & 0,010 & ACG & 1,000 & ACG & 1,000 \\
\hline & AGA & 0,000 & AGA & 0,049 & AGA & 0,002 & AGA & 0,008 & ACT & 0,741 & ACT & 0,000 & ACT & 0,917 & АCT & 0,999 \\
\hline & AGC & 0,721 & AGC & 0,947 & AGC & 0,717 & AGC & 0,741 & AGA & 1,000 & AGA & 0,367 & AGA & 0,049 & AGA & 0,168 \\
\hline & AGG & 0,013 & AGG & 0,040 & AGG & 0,010 & AGG & 0,010 & AGG & 1,000 & AGC & 1,000 & AGC & 0,961 & AGC & 0,950 \\
\hline & AGT & 0,000 & AGT & 0,002 & AGT & 0,000 & AGT & 0,000 & AGT & 1,000 & AGG & 1,000 & AGG & 0,048 & AGG & 0,042 \\
\hline & ATA & 0,827 & ATA & 1,000 & ATA & 0,851 & ATA & 0,903 & ATA & 1,000 & ATA & 0,249 & AGT & 0,002 & AGT & 0,005 \\
\hline & ATC & 0,567 & ATC & 1,000 & ATC & 0,783 & ATC & 0,917 & ATC & 0,961 & ATC & 0,002 & ATA & 1,000 & ATA & 1,000 \\
\hline & ATG & 0,756 & ATG & 1,000 & ATG & 0,829 & ATG & 0,912 & ATG & 0,992 & ATG & 0,020 & ATG & 1,000 & ATC & 1,000 \\
\hline & ATT & 0,989 & ATT & 1,000 & ATT & 0,995 & ATT & 0,999 & ATा & 0,950 & ATT & 0,005 & ATT & 1,000 & ATG & 1,000 \\
\hline & GAA & 1,000 & GAA & 0,981 & GAA & 1,000 & GAA & 1,000 & GAA & 0,773 & GAA & 0,000 & GAA & 0,869 & GAA & 1,000 \\
\hline & GAC & 1,000 & GAC & 0,560 & GAC & 1,000 & GAC & 1,000 & GAC & 0,645 & GAC & 0,000 & GAC & 0,288 & GAC & 0,904 \\
\hline & GAG & 0,161 & GAG & 1,000 & GAG & 0,317 & GAG & 0,525 & GAG & 0,994 & GAG & 0,008 & GAG & 1,000 & GAG & 1,000 \\
\hline & GAT & 1,000 & GAT & 0,996 & GAT & 1,000 & GAT & 1,000 & GAT & 0,772 & GAT & 0,001 & GAT & 0,972 & GAT & 1,000 \\
\hline & GCA & 1,000 & GCA & 0,932 & GCA & 1,000 & GCA & 1,000 & GCA & 0,746 & GCA & 0,000 & GCA & 0,725 & GCA & 0,997 \\
\hline & GCC & 0,623 & GCC & 0,154 & GCC & 0,842 & GCC & 0,896 & GCC & 0,356 & GCC & 0,000 & GCC & 0,099 & GCC & 0,313 \\
\hline & GCG & 1,000 & GCG & 1,000 & GCG & 1,000 & GCG & 1,000 & GCG & 0,830 & GCG & 0,001 & GCG & 0,987 & GCG & 1,000 \\
\hline & GCT & 0,502 & GCT & 0,094 & GCT & 0,786 & GCT & 0,864 & GCT & 0,358 & GCT & 0,000 & GCT & 0,053 & GCT & 0,252 \\
\hline & GGA & 0,000 & GGA & 0,038 & GGA & 0,002 & GGA & 0,011 & GGA & 1,000 & GGA & 0,170 & GGA & 0,028 & GGA & 0,176 \\
\hline & GGC & 0,250 & GGC & 0,742 & GGC & 0,255 & GGC & 0,296 & GGC & 1,000 & GGC & 0,946 & GGC & 0,790 & GGC & 0,791 \\
\hline & GGG & 0,020 & GGG & 0,044 & GGG & 0,017 & GGG & 0,017 & GGG & 0,989 & GGG & 0,981 & GGG & 0,050 & GGG & 0,041 \\
\hline & GGT & 0,026 & GGT & 0,121 & GGT & 0,022 & GGT & 0,026 & GGT & 1,000 & GGT & 1,000 & GGT & 0,141 & GGT & 0,149 \\
\hline & GTA & 0,000 & GTA & 0,014 & GTA & 0,001 & GTA & 0,005 & GTA & 1,000 & GTA & 0,325 & GTA & 0,009 & GTA & 0,090 \\
\hline & GTC & 0,902 & GTC & 1,000 & GTC & 0,979 & GTC & 0,997 & GTC & 0,893 & GTC & 0,001 & GTC & 1,000 & GTC & 1,000 \\
\hline & GTG & 0,001 & GTG & 0,090 & GTG & 0,003 & GTG & 0,014 & GTG & 1,000 & GTG & 0,215 & GTG & 0,092 & GTG & 0,262 \\
\hline & GT & 0,815 & GT & 1,000 & GT & 0,856 & GTT & 0,918 & GTT & 0,997 & GT & 0,072 & GTT & 1,000 & GTT & 1,000 \\
\hline
\end{tabular}


26. ábra

\begin{tabular}{|c|c|c|c|c|c|c|c|c|c|c|c|c|c|c|c|c|}
\hline \multirow[t]{31}{*}{ GAA } & $\overline{A A A}$ & 0,513 GAG & AAA & 0,019 GCA & AAA & 0,568 GCG & AAA & 0,309 GGA & $\overline{A A A}$ & 0,001 GGG & AAA & 0,005 GTA & AAA & 0,000 GTG & AAA & 0,000 \\
\hline & AAC & 1,000 & AAC & 0,161 & AAC & 1,000 & AAC & 1,000 & AAC & 0,000 & AAC & 0,020 & AAC & 0,000 & AAC & 0,001 \\
\hline & AAG & 0,995 & AAG & 1,000 & AAG & 0,986 & AAG & 1,000 & AAG & 0,851 & AAG & 0,085 & AAG & 0,675 & AAG & 0,916 \\
\hline & AAT & 0,981 & AAT & 1,000 & AAT & 0,932 & AAT & 1,000 & AAT & 0,038 & AAT & 0,044 & AAT & 0,014 & AAT & 0,090 \\
\hline & ACA & 1,000 & ACA & 0,865 & ACA & 1,000 & ACA & 1,000 & ACA & 0,020 & ACA & 0,025 & ACA & 0,010 & ACA & 0,033 \\
\hline & ACC & 1,000 & $\mathrm{ACC}$ & 0,317 & $\mathrm{ACC}$ & 1,000 & $\mathrm{ACC}$ & 1,000 & $\mathrm{ACC}$ & 0,002 & ACC & 0,017 & $\mathrm{ACC}$ & 0,001 & $\mathrm{ACC}$ & 0,003 \\
\hline & ACG & 1,000 & ACG & 0,999 & ACG & 1,000 & ACG & 1,000 & ACG & 0,264 & ACG & 0,036 & ACG & 0,157 & ACG & 0,344 \\
\hline & ACT & 1,000 & ACT & 0,525 & ACT & 1,000 & ACT & 1,000 & ACT & 0,011 & ACT & 0,017 & ACT & 0,005 & $\mathrm{ACT}$ & 0,014 \\
\hline & AGA & 0,001 & AGA & 0,303 & AGA & 0,001 & AGA & 0,002 & AGA & 1,000 & AGA & 0,347 & AGA & 1,000 & AGA & 1,000 \\
\hline & AGC & 0,773 & AGC & 0,994 & AGC & 0,746 & AGC & 0,830 & AGC & 1,000 & AGC & 0,989 & AGC & 1,000 & AGC & 1,000 \\
\hline & AGG & 0,015 & AGG & 0,095 & AGG & 0,014 & AGG & 0,020 & AGG & 0,497 & AGG & 1,000 & AGG & 0,659 & AGG & 0,524 \\
\hline & AGT & 0,000 & AGT & 0,008 & AGT & 0,000 & AGT & 0,001 & AGT & 0,170 & AGT & 0,981 & AGT & 0,325 & AGT & 0,215 \\
\hline & ATA & 0,914 & ATA & 1,000 & ATA & 0,872 & ATA & 0,971 & ATA & 0,994 & ATA & 0,152 & ATA & 0,948 & ATA & 0,998 \\
\hline & ATC & 0,869 & ATC & 1,000 & ATC & 0,725 & ATC & 0,987 & ATC & 0,028 & ATC & 0,050 & ATC & 0,009 & ATC & 0,092 \\
\hline & ATG & 0,905 & ATG & 1,000 & ATG & 0,834 & ATG & 0,981 & ATG & 0,562 & ATG & 0,071 & ATG & 0,333 & ATG & 0,722 \\
\hline & ATT & 1,000 & $\mathrm{ATT}$ & 1,000 & ATT & 0,997 & $\mathrm{ATT}$ & 1,000 & ATT & 0,176 & ATT & 0,041 & ATT & 0,090 & ATT & 0,262 \\
\hline & GAC & 1,000 & GAA & 0,348 & GAA & 1,000 & GAA & 1,000 & GAA & 0,000 & GAA & 0,023 & GAA & 0,000 & GAA & 0,002 \\
\hline & GAG & 0,348 & GAC & 0,071 & GAC & 1,000 & GAC & 0,957 & GAC & 0,000 & GAC & 0,016 & GAC & 0,000 & GAC & 0,000 \\
\hline & GAT & 1,000 & GAT & 0,687 & GAG & 0,235 & GAG & 0,592 & GAG & 0,240 & GAG & 0,080 & GAG & 0,086 & GAG & 0,497 \\
\hline & GCA & 1,000 & GCA & 0,235 & GAT & 1,000 & GAT & 1,000 & GAT & 0,024 & GAT & 0,018 & GAT & 0,013 & GAT & 0,031 \\
\hline & GCC & 0,528 & GCC & 0,035 & GCC & 0,577 & GCA & 1,000 & GCA & 0,000 & GCA & 0,022 & GCA & 0,000 & GCA & 0,001 \\
\hline & GCG & 1,000 & GCG & 0,592 & GCG & 1,000 & GCC & 0,353 & GCC & 0,002 & GCC & 0,004 & GCC & 0,001 & GCC & 0,002 \\
\hline & GCT & 0,408 & GCT & 0,016 & GCT & 0,456 & GCT & 0,242 & GCG & 0,000 & GCG & 0,028 & GCG & 0,000 & GCG & 0,003 \\
\hline & GGA & 0,000 & GGA & 0,240 & GGA & 0,000 & GGA & 0,000 & GCT & 0,001 & GCT & 0,005 & GCT & 0,000 & GCT & 0,000 \\
\hline & GGC & 0,314 & GGC & 0,969 & GGC & 0,278 & GGC & 0,404 & GGC & 1,000 & GGA & 0,282 & GGA & 1,000 & GGA & 1,000 \\
\hline & GGG & 0,023 & GGG & 0,080 & GGG & 0,022 & GGG & 0,028 & GGG & 0,282 & GGC & 0,565 & GGC & 1,000 & GGC & 1,000 \\
\hline & GGT & 0,033 & GGT & 0,313 & GGT & 0,029 & GGT & 0,046 & GGT & 0,973 & GGT & 0,887 & GGG & 0,363 & GGG & 0,284 \\
\hline & GTA & 0,000 & GTA & 0,086 & GTA & 0,000 & GTA & 0,000 & GTA & 1,000 & GTA & 0,363 & GGT & 0,998 & GGT & 0,982 \\
\hline & GTC & 0,998 & GTC & 0,895 & GTC & 0,978 & GTC & 1,000 & GTC & 0,001 & GTC & 0,036 & GTC & 0,000 & GTA & 1,000 \\
\hline & GTG & 0,002 & GTG & 0,497 & GTG & 0,001 & GTG & 0,003 & GTG & 1,000 & GTG & 0,284 & GTG & 1,000 & GTC & 0,009 \\
\hline & GTT & 0,922 & GTT & 1,000 & GTT & 0,871 & GTT & 0,981 & GTT & 0,865 & GTT & 0,094 & GT & 0,665 & GTT & 0,937 \\
\hline \multirow[t]{31}{*}{ GAC } & AAA & 0,898 GAT & AAA & 0,929 GCC & AAA & $1,000 \mathrm{GCT}$ & AAA & 1,000 GGC & AAA & 0,052 GGT & AAA & $0,003 \mathrm{GTC}$ & AAA & $0,142 \mathrm{GTT}$ & AAA & 0,198 \\
\hline & AAC & 1,000 & AAC & 1,000 & AAC & 0,623 & AAC & 0,502 & AAC & 0,250 & AAC & 0,026 & AAC & 0,902 & AAC & 0,815 \\
\hline & AAG & 0,898 & AAG & 0,997 & AAG & 0,387 & AAG & 0,359 & AAG & 0,989 & AAG & 0,531 & AAG & 1,000 & AAG & 1,000 \\
\hline & AAT & 0,560 & AAT & 0,996 & AAT & 0,154 & AAT & 0,094 & AAT & 0,742 & AAT & 0,121 & AAT & 1,000 & AAT & 1,000 \\
\hline & ACA & 0,999 & ACA & 1,000 & $\mathrm{ACA}$ & 0,574 & $\mathrm{ACA}$ & 0,490 & ACA & 0,466 & ACA & 0,051 & $\mathrm{ACA}$ & 1,000 & ACA & 0,994 \\
\hline & ACC & 1,000 & ACC & 1,000 & $\mathrm{ACC}$ & 0,842 & $\mathrm{ACC}$ & 0,786 & ACC & 0,255 & ACC & 0,022 & ACC & 0,979 & $\mathrm{ACC}$ & 0,856 \\
\hline & ACG & 0,996 & ACG & 1,000 & $A C G$ & 0,604 & ACG & 0,557 & ACG & 0,768 & ACG & 0,154 & ACG & 1,000 & ACG & 1,000 \\
\hline & ACT & 1,000 & ACT & 1,000 & $\mathrm{ACT}$ & 0,896 & ACT & 0,864 & ACT & 0,296 & ACT & 0,026 & ACT & 0,997 & $\mathrm{ACT}$ & 0,918 \\
\hline & AGA & 0,000 & AGA & 0,019 & AGA & 0,001 & AGA & 0,000 & AGA & 1,000 & AGA & 0,998 & AGA & 0,005 & AGA & 0,842 \\
\hline & AGC & 0,645 & AGC & 0,772 & AGC & 0,356 & AGC & 0,358 & AGC & 1,000 & AGC & 1,000 & AGC & 0,893 & AGC & 0,997 \\
\hline & AGG & 0,009 & AGG & 0,012 & AGG & 0,001 & AGG & 0,002 & AGG & 0,941 & AGG & 1,000 & AGG & 0,029 & AGG & 0,162 \\
\hline & AGT & 0,000 & AGT & 0,001 & AGT & 0,000 & AGT & 0,000 & AGT & 0,946 & AGT & 1,000 & AGT & 0,001 & AGT & 0,072 \\
\hline & ATA & 0,686 & ATA & 0,943 & ATA & 0,231 & ATA & 0,214 & ATA & 1,000 & ATA & 0,821 & ATA & 0,997 & ATA & 1,000 \\
\hline & ATC & 0,288 & ATC & 0,972 & ATC & 0,099 & ATC & 0,053 & ATC & 0,790 & ATC & 0,141 & ATC & 1,000 & ATC & 1,000 \\
\hline & ATG & 0,545 & ATG & 0,961 & ATG & 0,133 & ATG & 0,101 & ATG & 0,971 & ATG & 0,356 & ATG & 1,000 & ATG & 1,000 \\
\hline & ATा & 0,904 & ATा & 1,000 & ATT & 0,313 & ATT & 0,252 & ATT & 0,791 & ATा & 0,149 & ATT & 1,000 & ATT & 1,000 \\
\hline & GAA & 1,000 & GAA & 1,000 & GAA & 0,528 & GAA & 0,408 & GAA & 0,314 & GAA & 0,033 & GAA & 0,998 & GAA & 0,922 \\
\hline & GAG & 0,071 & GAC & 1,000 & GAC & 0,861 & GAC & 0,794 & GAC & 0,181 & GAC & 0,018 & GAC & 0,548 & GAC & 0,642 \\
\hline & GAT & 1,000 & GAG & 0,687 & GAG & 0,035 & GAG & 0,016 & GAG & 0,969 & GAG & 0,313 & GAG & 0,895 & GAG & 1,000 \\
\hline & GCA & 1,000 & GCA & 1,000 & GAT & 0,886 & GAT & 0,855 & GAT & 0,350 & GAT & 0,033 & GAT & 1,000 & GAT & 0,960 \\
\hline & GCC & 0,861 & GCC & 0,886 & $\mathrm{GCA}$ & 0,577 & GCA & 0,456 & GCA & 0,278 & GCA & 0,029 & GCA & 0,978 & GCA & 0,871 \\
\hline & GCG & 0,957 & GCG & 1,000 & GCG & 0,353 & GCC & 1,000 & GCC & 0,043 & GCC & 0,003 & GCC & 0,194 & $\mathrm{GCC}$ & 0,181 \\
\hline & GCT & 0,794 & GCT & 0,855 & GCT & 1,000 & GCG & 0,242 & GCG & 0,404 & GCG & 0,046 & GCG & 1,000 & GCG & 0,981 \\
\hline & GGA & 0,000 & GGA & 0,024 & GGA & 0,002 & GGA & 0,001 & GCT & 0,042 & GCT & 0,002 & GCT & 0,114 & GCT & 0,156 \\
\hline & GGC & 0,181 & GGC & 0,350 & GGC & 0,043 & GGC & 0,042 & GGA & 1,000 & GGA & 0,973 & GGA & 0,001 & GGA & 0,865 \\
\hline & GGG & 0,016 & GGG & 0,018 & GGG & 0,004 & GGG & 0,005 & GGG & 0,565 & GGC & 1,000 & GGC & 0,539 & GGC & 0,995 \\
\hline & GGT & 0,018 & GGT & 0,033 & GGT & 0,003 & GGT & 0,002 & GGT & 1,000 & GGG & 0,887 & GGG & 0,036 & GGG & 0,094 \\
\hline & GTA & 0,000 & GTA & 0,013 & GTA & 0,001 & GTA & 0,000 & GTA & 1,000 & GTA & 0,998 & GGT & 0,071 & GGT & 0,551 \\
\hline & GTC & 0,548 & GTC & 1,000 & GTC & 0,194 & GTC & 0,114 & GTC & 0,539 & GTC & 0,071 & GTA & 0,000 & GTA & 0,665 \\
\hline & GTG & 0,000 & GTG & 0,031 & GTG & 0,002 & GTG & 0,000 & GTG & 1,000 & GTG & 0,982 & GTG & 0,009 & GTC & 0,999 \\
\hline & GTT & 0,642 & GT & 0,960 & $\mathrm{GTT}$ & 0,181 & $\mathrm{GTT}$ & 0,156 & $\mathrm{GTT}$ & 0,995 & $\mathrm{GTT}$ & 0,551 & GT & 0,999 & GTG & 0,937 \\
\hline
\end{tabular}


7sk promóter eredményeihez kapcsolódó p értékek

$(0,000$ jelentése $<0,001)$

32. ábra

33. ábra

\begin{tabular}{|rrr|}
\hline$A$ & $C$ & 0,000 \\
G & 0,000 \\
& $T$ & 0,000 \\
C & $A$ & 0,000 \\
G & 0,000 \\
T & 1,000 \\
G & A & 0,000 \\
C & 0,000 \\
T & 0,000 \\
$T$ & A & 0,000 \\
C & 1,000 \\
G & 0,000 \\
\hline
\end{tabular}

\begin{tabular}{|c|c|c|c|c|c|c|c|c|}
\hline AA & $A A C$ & $1,000 \mathrm{CA}$ & AA & $0,000 \mathrm{GA}$ & AA & $0,001 \mathrm{TA}$ & AA & 0,031 \\
\hline & $A G$ & 0,000 & $A C$ & 0,000 & $A C$ & 0,007 & $A C$ & 0,007 \\
\hline & AT & 0,984 & $A G$ & 0,000 & $A G$ & 0,000 & $A G$ & 0,000 \\
\hline & CA & 0,000 & AT & 0,000 & AT & 0,150 & AT & 0,000 \\
\hline & $\mathrm{CC}$ & 0,000 & $\mathrm{CC}$ & 0,006 & CA & 0,000 & CA & 0,998 \\
\hline & CG & 1,000 & CG & 0,004 & CC & 0,000 & CC & 0,000 \\
\hline & CT & 0,000 & CT & 0,000 & CG & 0,000 & CG & 0,16 \\
\hline & GA & 0,001 & GA & 0,000 & ст & 0,000 & ст & 0,000 \\
\hline & GC & 1,000 & $\mathrm{GC}$ & 0,000 & GC & 0,004 & GA & 0,000 \\
\hline & GG & 0,000 & GG & 0,000 & GG & 0,000 & GC & 0,012 \\
\hline & GT & 0,000 & GT & 0,000 & GT & 0,000 & GG & 0,000 \\
\hline & TA & 0,031 & TA & 0,998 & TA & 0,000 & GT & 0,000 \\
\hline & TC & 0,000 & TC & 0,000 & TC & 0,000 & TC & 0,000 \\
\hline & TG & 1,000 & TG & 0,000 & TG & 0,006 & TG & 0,00 \\
\hline & $\pi$ & 0,000 & $\pi$ & 0,000 & $\pi$ & 0,000 & $\pi$ & 0,000 \\
\hline$A C$ & AA & $1,000 \mathrm{CC}$ & $A A$ & $0,000 \mathrm{GC}$ & AA & $1,000 \mathrm{TC}$ & AA & 0,000 \\
\hline & $A G$ & 0,000 & $A C$ & 0,000 & AC & 1,000 & AC & 0,00 \\
\hline & AT & 1,000 & $A G$ & 0,000 & AG & 0,000 & $A G$ & 0,000 \\
\hline & CA & 0,000 & AT & 0,000 & AT & 0,998 & AT & 0,000 \\
\hline & CC & 0,000 & CA & 0,006 & CA & 0,000 & CA & 0,000 \\
\hline & CG & 1,000 & CG & 0,000 & $\mathrm{CC}$ & 0,000 & CC & 0,969 \\
\hline & CT & 0,000 & CT & 0,994 & CG & 1,000 & CG & 0,000 \\
\hline & GA & 0,007 & GA & 0,000 & CT & 0,000 & СT & 1,000 \\
\hline & GC & 1,000 & $\mathrm{GC}$ & 0,000 & GA & 0,004 & GA & 0,000 \\
\hline & GG & 0,000 & GG & 0,000 & GG & 0,000 & GC & 0,000 \\
\hline & GT & 0,000 & GT & 0,000 & GT & 0,000 & GG & 0,00 \\
\hline & TA & 0,007 & TA & 0,000 & TA & 0,012 & GT & 0,000 \\
\hline & TC & 0,000 & TC & 0,969 & TC & 0,000 & TA & 0,000 \\
\hline & TG & 1,000 & TG & 0,000 & TG & 1,000 & TG & 0,00 \\
\hline & $\pi$ & 0,000 & $\pi$ & 0,525 & $\pi$ & 0,000 & $\pi$ & 1,000 \\
\hline AG & $3 \mathrm{AA}$ & $0,000 \mathrm{CG}$ & AA & $1,000 \mathrm{GG}$ & AA & 0,000 TG & $A A$ & 1,000 \\
\hline & $A C$ & 0,000 & $A C$ & 1,000 & $A C$ & 0,000 & $A C$ & 1,000 \\
\hline & AT & 0,000 & $A G$ & 0,000 & AG & 0,000 & AG & 0,00 \\
\hline & CA & 0,000 & AT & 0,781 & AT & 0,000 & AT & 1,000 \\
\hline & $\mathrm{CC}$ & 0,000 & CA & 0,004 & CA & 0,000 & CA & 0,000 \\
\hline & CG & 0,000 & $\mathrm{CC}$ & 0,000 & CC & 0,000 & CC & 0,00 \\
\hline & CT & 0,000 & CT & 0,000 & CG & 0,000 & CG & 1,000 \\
\hline & GA & 0,000 & GA & 0,000 & CT & 0,000 & CT & 0,000 \\
\hline & GC & 0,000 & GC & 1,000 & GA & 0,000 & GA & 0,006 \\
\hline & GG & 0,000 & GG & 0,000 & GC & 0,000 & GC & 1,000 \\
\hline & GT & 1,000 & GT & 0,000 & GT & 0,000 & GG & 0,000 \\
\hline & TA & 0,000 & TA & 0,164 & TA & 0,000 & GT & 0,000 \\
\hline & TC & 0,000 & TC & 0,000 & TC & 0,000 & TA & 0,008 \\
\hline & TG & 0,000 & TG & 1,000 & TG & 0,000 & TC & 0,000 \\
\hline & $\pi$ & 0,000 & $\pi$ & 0,000 & $\pi$ & 0,000 & $\pi$ & 0,000 \\
\hline AT & AA & $0,984 \mathrm{CT}$ & AA & $0,000 \mathrm{GT}$ & AA & $0,000 \mathrm{TT}$ & AA & 0,000 \\
\hline & $A C$ & 1,000 & $A C$ & 0,000 & AC & 0,000 & AC & 0,000 \\
\hline & $A G$ & 0,000 & $A G$ & 0,000 & AG & 1,000 & $A G$ & 0,000 \\
\hline & $\mathrm{CA}$ & 0,000 & AT & 0,000 & AT & 0,000 & AT & 0,00 \\
\hline & $\mathrm{CC}$ & 0,000 & CA & 0,000 & CA & 0,000 & $C A$ & 0,000 \\
\hline & CG & 0,781 & $\mathrm{CC}$ & 0,994 & $\mathrm{CC}$ & 0,000 & $\mathrm{CC}$ & 0,52 \\
\hline & CT & 0,000 & CG & 0,000 & CG & 0,000 & CG & 0,00 \\
\hline & GA & 0,150 & GA & 0,000 & CT & 0,000 & CT & 0,999 \\
\hline & c & 0,998 & $\mathrm{GC}$ & 0,000 & GA & 0,000 & GA & 0,00 \\
\hline & GG & 0,000 & GG & 0,000 & GC & 0,000 & GC & 0,00 \\
\hline & GT & 0,000 & GT & 0,000 & GG & 0,000 & GG & 0,000 \\
\hline & TA & 0,000 & TA & 0,000 & TA & 0,000 & GT & 0,000 \\
\hline & TC & 0,000 & TC & 1,000 & TC & 0,000 & TA & 0,00 \\
\hline & TG & 1,000 & TG & 0,000 & TG & 0,000 & TC & 1,000 \\
\hline & $\pi$ & 0,000 & $\pi$ & 0,999 & $\pi$ & 0,000 & TG & 0,00 \\
\hline
\end{tabular}


34. ábra

\begin{tabular}{|c|c|c|c|c|c|c|c|c|c|c|c|c|c|c|c|c|}
\hline \multirow[t]{31}{*}{ AAA } & AAC & 0,087 AAG & AAA & 0,008 ACA & AAA & 0,005 ACG & AAA & 0,399 AGA & AAA & 0,001 AGG & AAA & 0,000 ATA & AAA & 0,106 ATG & AAA & 0,013 \\
\hline & AAG & 0,008 & AAC & 0,953 & AAC & 0,456 & AAC & 1,000 & AAC & 0,066 & AAC & 0,000 & AAC & 0,984 & AAC & 0,991 \\
\hline & AAT & 0,054 & AAT & 0,839 & AAG & 1,000 & AAG & 1,000 & AAG & 0,344 & AAG & 0,003 & AAG & 1,000 & AAG & 1,000 \\
\hline & ACA & 0,005 & ACA & 1,000 & AAT & 0,041 & AAT & 1,000 & AAT & 0,065 & AAT & 0,000 & AAT & 0,974 & AAT & 0,958 \\
\hline & $A C C$ & 0,866 & $A C C$ & 0,708 & $A C C$ & 0,421 & ACA & 0,992 & ACA & 0,314 & ACA & 0,000 & ACA & 1,000 & ACA & 1,000 \\
\hline & ACG & 0,399 & ACG & 1,000 & $A C G$ & 0,992 & $\mathrm{ACC}$ & 1,000 & $\mathrm{ACC}$ & 0,030 & $\mathrm{ACC}$ & 0,002 & $\mathrm{ACC}$ & 0,853 & ACC & 0,820 \\
\hline & ACT & 0,889 & ACT & 0,255 & ACT & 0,080 & ACT & 0,999 & ACG & 0,174 & ACG & 0,023 & ACG & 0,999 & ACG & 1,000 \\
\hline & AGA & 0,001 & AGA & 0,344 & AGA & 0,314 & AGA & 0,174 & ACT & 0,013 & $\mathrm{ACT}$ & 0,000 & ACT & 0,633 & ACT & 0,386 \\
\hline & $A G C$ & 0,000 & AGC & 0,106 & AGC & 0,097 & $A G C$ & 0,059 & AGC & 1,000 & AGA & 1,000 & AGA & 0,947 & AGA & 0,323 \\
\hline & AGG & 0,000 & AGG & 0,003 & AGG & 0,000 & AGG & 0,023 & AGG & 1,000 & AGC & 1,000 & AGC & 0,796 & $A G C$ & 0,100 \\
\hline & AGT & 0,000 & AGT & 0,001 & AGT & 0,000 & AGT & 0,008 & AGT & 1,000 & AGT & 1,000 & AGG & 0,637 & AGG & 0,006 \\
\hline & ATA & 0,106 & ATA & 1,000 & ATA & 1,000 & ATA & 0,999 & ATA & 0,947 & ATA & 0,637 & AGT & 0,354 & AGT & 0,001 \\
\hline & ATC & 0,011 & ATC & 1,000 & ATC & 1,000 & ATC & 1,000 & ATC & 0,352 & ATC & 0,007 & ATC & 1,000 & ATA & 1,000 \\
\hline & ATG & 0,013 & ATG & 1,000 & ATG & 1,000 & ATG & 1,000 & ATG & 0,323 & ATG & 0,006 & ATG & 1,000 & ATC & 1,000 \\
\hline & ATT & 1,000 & ATT & 0,003 & ATT & 0,001 & ATT & 0,457 & ATT & 0,002 & ATT & 0,000 & ATT & 0,134 & ATT & 0,007 \\
\hline & GAA & 0,002 & GAA & 1,000 & GAA & 0,999 & GAA & 0,918 & GAA & 0,774 & GAA & 0,063 & GAA & 1,000 & GAA & 1,000 \\
\hline & GAC & 0,013 & GAC & 1,000 & GAC & 0,809 & GAC & 1,000 & GAC & 0,168 & GAC & 0,000 & GAC & 1,000 & GAC & 1,000 \\
\hline & GAG & 0,021 & GAG & 0,876 & GAG & 0,861 & GAG & 0,618 & GAG & 1,000 & GAG & 1,000 & GAG & 1,000 & GAG & 0,856 \\
\hline & GAT & 0,042 & GAT & 1,000 & GAT & 1,000 & GAT & 1,000 & GAT & 0,647 & GAT & 0,142 & GAT & 1,000 & GAT & 1,000 \\
\hline & GCA & 0,020 & GCA & 1,000 & GCA & 0,999 & GCA & 1,000 & GCA & 0,178 & GCA & 0,000 & GCA & 1,000 & GCA & 1,000 \\
\hline & GCC & 0,995 & GCC & 0,952 & GCC & 0,868 & GCC & 1,000 & GCC & 0,122 & GCC & 0,046 & GCC & 0,956 & GCC & 0,975 \\
\hline & GCG & 0,017 & GCG & 1,000 & GCG & 1,000 & GCG & 1,000 & GCG & 0,398 & GCG & 0,018 & GCG & 1,000 & GCG & 1,000 \\
\hline & GCT & 1,000 & GCT & 0,257 & GCT & 0,143 & GCT & 0,977 & GCT & 0,009 & GCT & 0,001 & GCT & 0,483 & GCT & 0,339 \\
\hline & GGA & 0,001 & GGA & 0,056 & GGA & 0,063 & GGA & 0,023 & GGA & 0,985 & GGA & 0,932 & GGA & 0,263 & GGA & 0,051 \\
\hline & GGC & 0,001 & GGC & 0,038 & GGC & 0,044 & GGC & 0,015 & GGC & 0,744 & GGC & 0,598 & GGC & 0,116 & GGC & 0,034 \\
\hline & GGG & 0,000 & GGG & 0,002 & GGG & 0,004 & GGG & 0,001 & GGG & 0,284 & GGG & 0,140 & GGG & 0,016 & GGG & 0,002 \\
\hline & GGT & 0,001 & GGT & 0,034 & GGT & 0,040 & GGT & 0,013 & GGT & 0,882 & GGT & 0,731 & GGT & 0,146 & GGT & 0,030 \\
\hline & GTA & 0,000 & GTA & 0,000 & GTA & 0,000 & GTA & 0,000 & GTA & 0,346 & GTA & 0,006 & GTA & 0,021 & GTA & 0,000 \\
\hline & GTC & 0,000 & GTC & 0,034 & GTC & 0,000 & GTC & 0,095 & GTC & 1,000 & GTC & 0,794 & GTC & 0,957 & GTC & 0,049 \\
\hline & GTG & 0,000 & GTG & 0,000 & GTG & 0,000 & GTG & 0,002 & GTG & 0,950 & GTG & 0,297 & GTG & 0,113 & GTG & 0,000 \\
\hline & GTT & 0,030 & GTT & 0,962 & GTT & 0,955 & GTT & 0,768 & GTT & 1,000 & GTT & 1,000 & GTT & 1,000 & GTT & 0,951 \\
\hline \multirow[t]{31}{*}{ AAC } & AAA & 0,087 AAT & AAA & $0,054 \mathrm{ACC}$ & AAA & $0,866 \mathrm{ACT}$ & AAA & 0,889 AGC & AAA & 0,000 AGT & AAA & 0,000 ATC & AAA & 0,011 ATT & AAA & 1,000 \\
\hline & AAG & 0,953 & AAC & 1,000 & AAC & 1,000 & AAC & 0,968 & AAC & 0,013 & AAC & 0,000 & AAC & 0,981 & AAC & 0,045 \\
\hline & AAT & 1,000 & AAG & 0,839 & AAG & 0,708 & AAG & 0,255 & AAG & 0,106 & AAG & 0,001 & AAG & 1,000 & AAG & 0,003 \\
\hline & ACA & 0,456 & ACA & 0,041 & AAT & 0,999 & AAT & 0,856 & AAT & 0,014 & AAT & 0,000 & AAT & 0,927 & AAT & 0,014 \\
\hline & $\mathrm{ACC}$ & 1,000 & $\mathrm{ACC}$ & 0,999 & $\mathrm{ACA}$ & 0,421 & $A C A$ & 0,080 & $\mathrm{ACA}$ & 0,097 & $A C A$ & 0,000 & ACA & 1,000 & ACA & 0,001 \\
\hline & ACG & 1,000 & ACG & 1,000 & ACG & 1,000 & $\mathrm{ACC}$ & 1,000 & $\mathrm{ACC}$ & 0,006 & $\mathrm{ACC}$ & 0,001 & $\mathrm{ACC}$ & 0,779 & $\mathrm{ACC}$ & 0,922 \\
\hline & ACT & 0,968 & ACT & 0,856 & ACT & 1,000 & ACG & 0,999 & ACG & 0,059 & ACG & 0,008 & ACG & 1,000 & ACG & 0,457 \\
\hline & AGA & 0,066 & AGA & 0,065 & AGA & 0,030 & AGA & 0,013 & ACT & 0,002 & ACT & 0,000 & ACT & 0,339 & ACT & 0,940 \\
\hline & AGC & 0,013 & AGC & 0,014 & AGC & 0,006 & $A G C$ & 0,002 & AGA & 1,000 & AGA & 1,000 & AGA & 0,352 & AGA & 0,002 \\
\hline & AGG & 0,000 & AGG & 0,000 & AGG & 0,002 & AGG & 0,000 & AGG & 1,000 & $A G C$ & 1,000 & $A G C$ & 0,112 & $A G C$ & 0,000 \\
\hline & AGT & 0,000 & AGT & 0,000 & AGT & 0,001 & AGT & 0,000 & AGT & 1,000 & AGG & 1,000 & AGG & 0,007 & AGG & 0,000 \\
\hline & ATA & 0,984 & ATA & 0,974 & ATA & 0,853 & ATA & 0,633 & ATA & 0,796 & ATA & 0,354 & AGT & 0,001 & AGT & 0,000 \\
\hline & ATC & 0,981 & ATC & 0,927 & ATC & 0,779 & ATC & 0,339 & ATC & 0,112 & ATC & 0,001 & ATA & 1,000 & ATA & 0,134 \\
\hline & ATG & 0,991 & ATG & 0,958 & ATG & 0,820 & ATG & 0,386 & ATG & 0,100 & ATG & 0,001 & ATG & 1,000 & ATC & 0,006 \\
\hline & ATT & 0,045 & ATT & 0,014 & ATT & 0,922 & ATT & 0,940 & $\mathrm{ATT}$ & 0,000 & ATT & 0,000 & ATT & 0,006 & ATG & 0,007 \\
\hline & GAA & 0,379 & GAA & 0,231 & GAA & 0,261 & GAA & 0,050 & GAA & 0,414 & GAA & 0,011 & GAA & 1,000 & GAA & 0,001 \\
\hline & GAC & 0,928 & GAC & 0,370 & GAC & 0,728 & GAC & 0,224 & GAC & 0,046 & GAC & 0,000 & GAC & 1,000 & GAC & 0,002 \\
\hline & GAG & 0,406 & GAG & 0,382 & GAG & 0,230 & GAG & 0,137 & GAG & 1,000 & GAG & 1,000 & GAG & 0,877 & GAG & 0,030 \\
\hline & GAT & 0,990 & GAT & 0,977 & GAT & 0,852 & GAT & 0,543 & GAT & 0,340 & GAT & 0,047 & GAT & 1,000 & GAT & 0,049 \\
\hline & GCA & 1,000 & GCA & 0,999 & GCA & 0,936 & GCA & 0,554 & GCA & 0,043 & GCA & 0,000 & GCA & 1,000 & GCA & 0,008 \\
\hline & GCC & 1,000 & GCC & 1,000 & $\mathrm{GCC}$ & 1,000 & GCC & 1,000 & GCC & 0,059 & GCC & 0,023 & GCC & 0,966 & GCC & 0,999 \\
\hline & GCG & 0,990 & GCG & 0,964 & GCG & 0,825 & GCG & 0,425 & GCG & 0,140 & GCG & 0,004 & GCG & 1,000 & GCG & 0,013 \\
\hline & GCT & 0,860 & GCT & 0,745 & GCT & 1,000 & GCT & 1,000 & GCT & 0,002 & GCT & 0,000 & GCT & 0,306 & GCT & 1,000 \\
\hline & GGA & 0,016 & GGA & 0,019 & GGA & 0,006 & GGA & 0,004 & GGA & 0,993 & GGA & 0,997 & GGA & 0,055 & GGA & 0,001 \\
\hline & GGC & 0,014 & GGC & 0,016 & GGC & 0,006 & GGC & 0,005 & GGC & 0,790 & GGC & 0,825 & GGC & 0,036 & GGC & 0,002 \\
\hline & GGG & 0,001 & GGG & 0,001 & GGG & 0,000 & GGG & 0,000 & GGG & 0,301 & GGG & 0,297 & GGG & 0,002 & GGG & 0,000 \\
\hline & GGT & 0,011 & GGT & 0,013 & GGT & 0,004 & GGT & 0,003 & GGT & 0,917 & GGT & 0,937 & GGT & 0,033 & GGT & 0,001 \\
\hline & GTA & 0,000 & GTA & 0,000 & GTA & 0,000 & GTA & 0,000 & GTA & 0,303 & GTA & 0,059 & GTA & 0,000 & GTA & 0,000 \\
\hline & GTC & 0,000 & GTC & 0,000 & GTC & 0,009 & GTC & 0,001 & GTC & 0,997 & GTC & 0,143 & GTC & 0,058 & GTC & 0,000 \\
\hline & GTG & 0,000 & GTG & 0,000 & GTG & 0,000 & GTG & 0,000 & GTG & 0,972 & GTG & 0,949 & GTG & 0,000 & GTG & 0,000 \\
\hline & GT & 0,542 & GTT & 0,509 & GTT & 0,325 & GTT & 0,195 & GT & 1,000 & GTT & 0,989 & GTT & 0,962 & GT & 0,041 \\
\hline
\end{tabular}


34. ábra

\begin{tabular}{|c|c|c|c|c|c|c|c|c|c|c|c|c|c|c|c|c|}
\hline \multirow[t]{31}{*}{ GAA } & AAA & 0,002 GAG & AAA & 0,021 GCA & AAA & 0,020 GCG & AAA & 0,017 GGA & AAA & 0,001 GGG & AAA & 0,000 GTA & AAA & 0,000 GTG & AAA & 0,000 \\
\hline & AAC & 0,379 & AAC & 0,406 & AAC & 1,000 & AAC & 0,990 & AAC & 0,016 & AAC & 0,001 & AAC & 0,000 & AAC & 0,000 \\
\hline & AAG & 1,000 & AAG & 0,876 & AAG & 1,000 & AAG & 1,000 & AAG & 0,056 & AAG & 0,002 & AAG & 0,000 & AAG & 0,000 \\
\hline & AAT & 0,231 & AAT & 0,382 & AAT & 0,999 & AAT & 0,964 & AAT & 0,019 & AAT & 0,001 & AAT & 0,000 & AAT & 0,000 \\
\hline & ACA & 0,999 & ACA & 0,861 & ACA & 0,999 & ACA & 1,000 & ACA & 0,063 & $\mathrm{ACA}$ & 0,004 & ACA & 0,000 & ACA & 0,000 \\
\hline & ACC & 0,261 & $\mathrm{ACC}$ & 0,230 & ACC & 0,936 & ACC & 0,825 & $\mathrm{ACC}$ & 0,006 & $\mathrm{ACC}$ & 0,000 & ACC & 0,000 & ACC & 0,000 \\
\hline & ACG & 0,918 & ACG & 0,618 & ACG & 1,000 & ACG & 1,000 & ACG & 0,023 & ACG & 0,001 & ACG & 0,000 & ACG & 0,002 \\
\hline & ACT & 0,050 & ACT & 0,137 & ACT & 0,554 & ACT & 0,425 & ACT & 0,004 & ACT & 0,000 & ACT & 0,000 & ACT & 0,000 \\
\hline & AGA & 0,774 & AGA & 1,000 & AGA & 0,178 & AGA & 0,398 & AGA & 0,985 & AGA & 0,284 & AGA & 0,346 & AGA & 0,950 \\
\hline & AGC & 0,414 & AGC & 1,000 & AGC & 0,043 & AGC & 0,140 & AGC & 0,993 & $A G C$ & 0,301 & AGC & 0,303 & AGC & 0,972 \\
\hline & AGG & 0,063 & AGG & 1,000 & AGG & 0,000 & AGG & 0,018 & AGG & 0,932 & AGG & 0,140 & AGG & 0,006 & AGG & 0,297 \\
\hline & AGT & 0,011 & AGT & 1,000 & AGT & 0,000 & AGT & 0,004 & AGT & 0,997 & AGT & 0,297 & AGT & 0,059 & AGT & 0,949 \\
\hline & ATA & 1,000 & ATA & 1,000 & ATA & 1,000 & ATA & 1,000 & ATA & 0,263 & ATA & 0,016 & ATA & 0,021 & ATA & 0,113 \\
\hline & ATC & 1,000 & ATC & 0,877 & ATC & 1,000 & ATC & 1,000 & ATC & 0,055 & ATC & 0,002 & ATC & 0,000 & ATC & 0,000 \\
\hline & ATG & 1,000 & ATG & 0,856 & ATG & 1,000 & ATG & 1,000 & ATG & 0,051 & ATG & 0,002 & ATG & 0,000 & ATG & 0,000 \\
\hline & ATT & 0,001 & ATT & 0,030 & ATT & 0,008 & ATT & 0,013 & ATT & 0,001 & ATT & 0,000 & ATT & 0,000 & ATT & 0,000 \\
\hline & GAC & 0,802 & GAA & 0,996 & GAA & 0,942 & GAA & 1,000 & GAA & 0,140 & GAA & 0,006 & GAA & 0,000 & GAA & 0,001 \\
\hline & GAG & 0,996 & GAC & 0,662 & GAC & 1,000 & GAC & 1,000 & GAC & 0,039 & GAC & 0,003 & GAC & 0,000 & GAC & 0,000 \\
\hline & GAT & 1,000 & GAT & 0,974 & GAG & 0,688 & GAG & 0,900 & GAG & 0,958 & GAG & 0,283 & GAG & 0,411 & GAG & 0,914 \\
\hline & GCA & 0,942 & GCA & 0,688 & GAT & 1,000 & GAT & 1,000 & GAT & 0,098 & GAT & 0,004 & GAT & 0,001 & GAT & 0,009 \\
\hline & GCC & 0,700 & GCC & 0,400 & GCC & 0,995 & GCA & 1,000 & GCA & 0,033 & GCA & 0,001 & GCA & 0,000 & GCA & 0,000 \\
\hline & GCG & 1,000 & GCG & 0,900 & GCG & 1,000 & GCC & 0,973 & GCC & 0,015 & GCC & 0,001 & GCC & 0,002 & GCC & 0,008 \\
\hline & GCT & 0,073 & GCT & 0,091 & GCT & 0,476 & GCT & 0,351 & GCG & 0,059 & GCG & 0,002 & GCG & 0,000 & GCG & 0,000 \\
\hline & GGA & 0,140 & GGA & 0,958 & GGA & 0,033 & GGA & 0,059 & GCT & 0,002 & GCT & 0,000 & GCT & 0,000 & GCT & 0,000 \\
\hline & GGC & 0,079 & GGC & 0,675 & GGC & 0,025 & GGC & 0,037 & GGC & 1,000 & GGA & 1,000 & GGA & 1,000 & GGA & 1,000 \\
\hline & GGG & 0,006 & GGG & 0,283 & GGG & 0,001 & GGG & 0,002 & GGG & 1,000 & GGC & 1,000 & GGC & 1,000 & GGC & 0,991 \\
\hline & GGT & 0,080 & GGT & 0,821 & GGT & 0,021 & GGT & 0,034 & GGT & 1,000 & GGT & 1,000 & GGG & 1,000 & GGG & 0,722 \\
\hline & GTA & 0,000 & GTA & 0,411 & GTA & 0,000 & GTA & 0,000 & GTA & 1,000 & GTA & 1,000 & GGT & 1,000 & GGT & 1,000 \\
\hline & GTC & 0,406 & GTC & 1,000 & GTC & 0,005 & GTC & 0,119 & GTC & 0,557 & GTC & 0,046 & GTC & 0,000 & GTA & 0,724 \\
\hline & GTG & 0,001 & GTG & 0,914 & GTG & 0,000 & GTG & 0,000 & GTG & 1,000 & GTG & 0,722 & GTG & 0,724 & GTC & 0,004 \\
\hline & GTT & 1,000 & $\mathrm{GTT}$ & 1,000 & GTT & 0,834 & GTT & 0,973 & GT & 0,866 & GTT & 0,170 & GTT & 0,249 & GTT & 0,746 \\
\hline \multirow[t]{31}{*}{ GAC } & AAA & 0,013 GAT & AAA & $0,042 \mathrm{GCC}$ & AAA & 0,995 GCT & AAA & 1,000 GGC & AAA & 0,001 GGT & AAA & 0,001 GTC & AAA & $0,000 \mathrm{GTT}$ & AAA & 0,030 \\
\hline & AAC & 0,928 & AAC & 0,990 & AAC & 1,000 & AAC & 0,860 & AAC & 0,014 & AAC & 0,011 & AAC & 0,000 & AAC & 0,542 \\
\hline & AAG & 1,000 & AAG & 1,000 & AAG & 0,952 & AAG & 0,257 & AAG & 0,038 & AAG & 0,034 & AAG & 0,034 & AAG & 0,962 \\
\hline & AAT & 0,370 & AAT & 0,977 & AAT & 1,000 & AAT & 0,745 & AAT & 0,016 & AAT & 0,013 & AAT & 0,000 & AAT & 0,509 \\
\hline & ACA & 0,809 & ACA & 1,000 & ACA & 0,868 & ACA & 0,143 & ACA & 0,044 & ACA & 0,040 & ACA & 0,000 & ACA & 0,955 \\
\hline & $\mathrm{ACC}$ & 0,728 & $\mathrm{ACC}$ & 0,852 & $\mathrm{ACC}$ & 1,000 & $\mathrm{ACC}$ & 1,000 & $\mathrm{ACC}$ & 0,006 & $\mathrm{ACC}$ & 0,004 & $\mathrm{ACC}$ & 0,009 & $\mathrm{ACC}$ & 0,325 \\
\hline & ACG & 1,000 & ACG & 1,000 & ACG & 1,000 & ACG & 0,977 & ACG & 0,015 & ACG & 0,013 & ACG & 0,095 & ACG & 0,768 \\
\hline & ACT & 0,224 & ACT & 0,543 & ACT & 1,000 & ACT & 1,000 & ACT & 0,005 & ACT & 0,003 & ACT & 0,001 & ACT & 0,195 \\
\hline & AGA & 0,168 & AGA & 0,647 & AGA & 0,122 & AGA & 0,009 & AGA & 0,744 & AGA & 0,882 & AGA & 1,000 & AGA & 1,000 \\
\hline & AGC & 0,046 & AGC & 0,340 & AGC & 0,059 & AGC & 0,002 & AGC & 0,790 & AGC & 0,917 & AGC & 0,997 & AGC & 1,000 \\
\hline & AGG & 0,000 & AGG & 0,142 & AGG & 0,046 & AGG & 0,001 & AGG & 0,598 & AGG & 0,731 & AGG & 0,794 & AGG & 1,000 \\
\hline & AGT & 0,000 & AGT & 0,047 & AGT & 0,023 & AGT & 0,000 & AGT & 0,825 & AGT & 0,937 & AGT & 0,143 & AGT & 0,989 \\
\hline & ATA & 1,000 & ATA & 1,000 & ATA & 0,956 & ATA & 0,483 & ATA & 0,116 & ATA & 0,146 & ATA & 0,957 & ATA & 1,000 \\
\hline & ATC & 1,000 & ATC & 1,000 & ATC & 0,966 & ATC & 0,306 & ATC & 0,036 & ATC & 0,033 & ATC & 0,058 & ATC & 0,962 \\
\hline & ATG & 1,000 & ATG & 1,000 & ATG & 0,975 & ATG & 0,339 & ATG & 0,034 & ATG & 0,030 & ATG & 0,049 & ATG & 0,951 \\
\hline & ATT & 0,002 & ATT & 0,049 & ATT & 0,999 & ATT & 1,000 & ATT & 0,002 & ATT & 0,001 & ATT & 0,000 & ATT & 0,041 \\
\hline & GAA & 0,802 & GAA & 1,000 & GAA & 0,700 & GAA & 0,073 & GAA & 0,079 & GAA & 0,080 & GAA & 0,406 & GAA & 1,000 \\
\hline & GAG & 0,662 & GAC & 1,000 & GAC & 0,975 & GAC & 0,288 & GAC & 0,030 & GAC & 0,026 & GAC & 0,000 & GAC & 0,809 \\
\hline & GAT & 1,000 & GAG & 0,974 & GAG & 0,400 & GAG & 0,091 & GAG & 0,675 & GAG & 0,821 & GAG & 1,000 & GAG & 1,000 \\
\hline & GCA & 1,000 & GCA & 1,000 & GAT & 0,970 & GAT & 0,414 & GAT & 0,052 & GAT & 0,053 & GAT & 0,484 & GAT & 0,997 \\
\hline & GCC & 0,975 & GCC & 0,970 & GCA & 0,995 & GCA & 0,476 & GCA & 0,025 & GCA & 0,021 & GCA & 0,005 & GCA & 0,834 \\
\hline & GCG & 1,000 & GCG & 1,000 & GCG & 0,973 & GCC & 1,000 & GCC & 0,008 & GCC & 0,008 & GCC & 0,125 & GCC & 0,530 \\
\hline & GCT & 0,288 & GCT & 0,414 & GCT & 1,000 & GCG & 0,351 & GCG & 0,037 & GCG & 0,034 & GCG & 0,119 & GCG & 0,973 \\
\hline & GGA & 0,039 & GGA & 0,098 & GGA & 0,015 & GGA & 0,002 & GCT & 0,002 & GCT & 0,001 & GCT & 0,005 & GCT & 0,132 \\
\hline & GGC & 0,030 & GGC & 0,052 & GGC & 0,008 & GGC & 0,002 & GGA & 1,000 & GGA & 1,000 & GGA & 0,557 & GGA & 0,866 \\
\hline & GGG & 0,003 & GGG & 0,004 & GGG & 0,001 & GGG & 0,000 & GGG & 1,000 & GGC & 1,000 & GGC & 0,296 & GGC & 0,515 \\
\hline & GGT & 0,026 & GGT & 0,053 & GGT & 0,008 & GGT & 0,001 & GGT & 1,000 & GGG & 1,000 & GGG & 0,046 & GGG & 0,170 \\
\hline & GTA & 0,000 & GTA & 0,001 & GTA & 0,002 & GTA & 0,000 & GTA & 1,000 & GTA & 1,000 & GGT & 0,350 & GGT & 0,660 \\
\hline & GTC & 0,000 & GTC & 0,484 & GTC & 0,125 & GTC & 0,005 & GTC & 0,296 & GTC & 0,350 & GTA & 0,000 & GTA & 0,249 \\
\hline & GTG & 0,000 & GTG & 0,009 & GTG & 0,008 & GTG & 0,000 & GTG & 0,991 & GTG & 1,000 & GTG & 0,004 & GTC & 1,000 \\
\hline & GTT & 0,809 & GTT & 0,997 & GTT & 0,530 & GTT & 0,132 & GTT & 0,515 & GTT & 0,660 & GTT & 1,000 & GTG & 0,746 \\
\hline
\end{tabular}


T7 promóter eredményeihez kapcsolódó p értékek

$(0,000$ jelentése $<0,001)$

41. ábra

\begin{tabular}{|rrr}
\hline$A$ & $C$ & 0,000 \\
G & 0,000 \\
$T$ & 0,000 \\
C & $A$ & 0,000 \\
G & 0,000 \\
$T$ & 0,000 \\
G A & 0,000 \\
C & 0,000 \\
T & 0,000 \\
$T$ & $A$ & 0,000 \\
C & 0,000 \\
G & 0,000 \\
\hline
\end{tabular}

42. ábra

\begin{tabular}{|c|c|c|c|c|c|c|c|c|}
\hline \multirow[t]{15}{*}{$\widehat{A A}$} & $A \mathrm{AC}$ & $0,000 \mathrm{CA}$ & $\mathrm{AA}$ & $0,000 \mathrm{GA}$ & AA & $0,000 \mathrm{TA}$ & $A A$ & 0,026 \\
\hline & $A G$ & 0,000 & $A C$ & 0,000 & $A C$ & 0,001 & $A C$ & 0,000 \\
\hline & AT & 0,997 & $A G$ & 0,000 & AG & 0,441 & $A G$ & 0,000 \\
\hline & CA & 0,000 & AT & 0,000 & AT & 0,000 & AT & 0,351 \\
\hline & $\mathrm{CC}$ & 0,000 & $\mathrm{CC}$ & 0,601 & CA & 0,000 & CA & 0,000 \\
\hline & CG & 0,000 & CG & 0,005 & CC & 0,000 & $\mathrm{CC}$ & 0,000 \\
\hline & CT & 0,172 & $\mathrm{CT}$ & 0,092 & CG & 0,001 & CG & 0,000 \\
\hline & GA & 0,000 & GA & 0,000 & СT & 0,000 & CT & 0,005 \\
\hline & GC & 0,000 & GC & 0,000 & $\mathrm{GC}$ & 0,002 & GA & 0,000 \\
\hline & GG & 0,000 & GG & 0,000 & GG & 0,003 & GC & 0,000 \\
\hline & GT & 0,000 & GT & 0,000 & GT & 0,034 & GG & 0,00 \\
\hline & TA & 0,026 & TA & 0,000 & TA & 0,000 & GT & 0,000 \\
\hline & TC & 1,000 & TC & 0,000 & TC & 0,000 & TC & \\
\hline & TG & 0,000 & TG & 0,000 & TG & 0,001 & TG & 0,000 \\
\hline & $\pi$ & 0,000 & $\pi$ & 0,000 & $\pi$ & 0,000 & $\pi$ & 0,00 \\
\hline \multirow{15}{*}{$\mathrm{AC}$} & $A A$ & $0,000 \mathrm{CC}$ & $A A$ & $0,000 \mathrm{GC}$ & $A A$ & $0,000 \mathrm{TC}$ & $A A$ & 1,000 \\
\hline & $A G$ & 0,000 & $A C$ & 0,000 & $A C$ & 1,000 & $A C$ & 0,00 \\
\hline & AT & 0,000 & $A G$ & 0,000 & AG & 0,000 & $A G$ & 0,000 \\
\hline & CA & 0,000 & AT & 0,000 & AT & 0,000 & AT & 1,00 \\
\hline & $\mathrm{CC}$ & 0,000 & CA & 0,601 & CA & 0,000 & $\mathrm{CA}$ & 0,000 \\
\hline & CG & 0,110 & CG & 0,000 & $\mathrm{CC}$ & 0,000 & $\mathrm{CC}$ & 0,00 \\
\hline & CT & 0,000 & CT & 0,443 & CG & 0,003 & CG & 0,00 \\
\hline & GA & 0,001 & GA & 0,000 & ст & 0,000 & СT & 0,19 \\
\hline & GC & 1,000 & GC & 0,000 & GA & 0,002 & GA & 0,000 \\
\hline & GG & 0,986 & GG & 0,000 & GG & 0,929 & GC & \\
\hline & GT & 0,000 & GT & 0,000 & GT & 0,000 & GG & 0,00 \\
\hline & TA & 0,000 & TA & 0,000 & TA & 0,000 & GT & 0,000 \\
\hline & TC & 0,000 & TC & 0,000 & TC & 0,000 & TA & 0,112 \\
\hline & TG & 1,000 & TG & 0,000 & TG & 0,999 & TG & 0,000 \\
\hline & $\pi$ & 0,000 & $\pi$ & 0,000 & $\pi$ & 0,000 & $\pi$ & 0,001 \\
\hline \multirow[t]{15}{*}{$A G$} & $A A$ & $0,000 \mathrm{CG}$ & AA & $0,000 \mathrm{GG}$ & AA & $0,000 \mathrm{TG}$ & AA & 0,000 \\
\hline & $A C$ & 0,000 & $A C$ & 0,110 & $A C$ & 0,986 & $A C$ & \\
\hline & AT & 0,000 & $A G$ & 0,000 & AG & 0,000 & $A G$ & 0 \\
\hline & $\mathrm{CA}$ & 0,000 & AT & 0,000 & AT & 0,000 & AT & 0,000 \\
\hline & $\mathrm{CC}$ & 0,000 & $\mathrm{CA}$ & 0,005 & CA & 0,000 & $\mathrm{CA}$ & 0,000 \\
\hline & CG & 0,000 & $\mathrm{cc}$ & 0,000 & $\mathrm{cc}$ & 0,000 & $\mathrm{cC}$ & \\
\hline & СT & 0,000 & CT & 0,000 & CG & 0,020 & CG & 0 \\
\hline & GA & 0,441 & GA & 0,001 & CT & 0,000 & CT & 0,00 \\
\hline & GC & 0,000 & $\mathrm{GC}$ & 0,003 & GA & 0,003 & GA & 0,001 \\
\hline & GG & 0,000 & GG & 0,020 & GC & 0,929 & $\mathrm{GC}$ & 0,9 \\
\hline & GT & 0,014 & GT & 0,000 & GT & 0,013 & GG & \\
\hline & TA & 0,000 & TA & 0,000 & TA & 0,000 & GT & 0,000 \\
\hline & TC & 0,000 & TC & 0,000 & TC & 0,000 & TA & 0,00 \\
\hline & TG & 0,000 & TG & 0,081 & TG & 0,846 & TC & 0,000 \\
\hline & $\pi$ & 0,000 & $\pi$ & 0,000 & $\pi$ & 0,000 & $\pi$ & 0,00 \\
\hline \multirow[t]{15}{*}{ AT } & $A A$ & $0,997 \mathrm{CT}$ & AA & $0,172 \mathrm{GT}$ & AA & $0,000 \pi$ & AA & 0,000 \\
\hline & $A C$ & 0,000 & $A C$ & 0,000 & $A C$ & 0,000 & $A C$ & 0,000 \\
\hline & AG & 0,000 & $A G$ & 0,000 & $A G$ & 0,014 & $A G$ & 0,000 \\
\hline & $\mathrm{CA}$ & 0,000 & AT & 0,059 & AT & 0,000 & AT & 0,0 \\
\hline & $\mathrm{CC}$ & 0,000 & $\mathrm{CA}$ & 0,092 & CA & 0,000 & $\mathrm{CA}$ & 0,000 \\
\hline & CG & 0,000 & $\mathrm{cc}$ & 0,443 & $\mathrm{CC}$ & 0,000 & $\mathrm{CC}$ & 0,000 \\
\hline & СT & 0,059 & CG & 0,000 & CG & 0,000 & CG & 0,000 \\
\hline & GA & 0,000 & GA & 0,000 & CT & 0,000 & CT & 0,000 \\
\hline & c & 0,000 & GC & 0,000 & GA & 0,034 & GA & 0,000 \\
\hline & GG & 0,000 & GG & 0,000 & GC & 0,000 & GC & 0,000 \\
\hline & GT & 0,000 & GT & 0,000 & GG & 0,013 & GG & 0,00 \\
\hline & TA & 0,351 & TA & 0,005 & TA & 0,000 & GT & \\
\hline & TC & 1,000 & TC & 0,191 & TC & 0,000 & TA & 0,0 \\
\hline & TG & 0,000 & TG & 0,000 & TG & 0,000 & TC & 0,001 \\
\hline & $\pi$ & 0,001 & $\pi$ & 0,000 & $\pi$ & 0,000 & TG & \\
\hline
\end{tabular}




\begin{tabular}{|c|c|c|c|c|c|c|c|c|}
\hline \multirow[t]{15}{*}{ GAA } & GAC & $0,000 \mathrm{GCA}$ & GAA & 0,000 GGA & GAA & 0,000 GTA & GAA & 0,796 \\
\hline & GAG & 0,002 & GAC & 0,998 & GAC & 1,000 & GAC & 0,007 \\
\hline & GAT & 0,012 & GAG & 0,279 & GAG & 1,000 & GAG & 0,510 \\
\hline & GCA & 0,000 & GAT & 0,000 & GAT & 0,000 & GAT & 0,000 \\
\hline & GCC & 0,000 & GCC & 0,000 & GCA & 0,916 & GCA & 0,000 \\
\hline & GCG & 0,000 & GCG & 0,065 & GCC & 0,000 & GCC & 0,000 \\
\hline & GCT & 0,000 & GCT & 0,997 & GCG & 0,000 & GCG & 0,000 \\
\hline & GGA & 0,000 & GGA & 0,916 & GCT & 1,000 & GCT & 0,010 \\
\hline & GGC & 0,000 & GGC & 0,237 & GGC & 0,001 & GGA & 0,053 \\
\hline & GGG & 0,000 & GGG & 0,000 & GGG & 0,000 & GGC & 0,000 \\
\hline & GGT & 0,000 & GGT & 1,000 & GGT & 0,999 & GGG & 0,000 \\
\hline & GTA & 0,796 & GTA & 0,000 & GTA & 0,053 & GGT & 0,001 \\
\hline & GTC & 0,000 & GTC & 0,116 & GTC & 0,000 & GTC & 0,000 \\
\hline & GTG & 0,000 & GTG & 1,000 & GTG & 0,998 & GTG & 0,001 \\
\hline & GIT & 0,000 & GT & 0,998 & GTT & 1,000 & GT & 0,008 \\
\hline \multirow[t]{15}{*}{ GAC } & GAA & 0,000 GCC & GAA & $0,000 \mathrm{GGC}$ & GAA & $0,000 \mathrm{GTC}$ & GAA & 0,000 \\
\hline & GAG & 0,959 & GAC & 0,000 & GAC & 0,008 & GAC & 0,003 \\
\hline & GAT & 0,000 & GAG & 0,000 & GAG & 0,000 & GAG & 0,000 \\
\hline & GCA & 0,998 & GAT & 0,000 & GAT & 0,000 & GAT & 0,000 \\
\hline & GCC & 0,000 & GCA & 0,000 & GCA & 0,237 & GCA & 0,116 \\
\hline & GCG & 0,001 & GCG & 0,428 & GCC & 0,148 & GCC & 0,289 \\
\hline & GCT & 1,000 & GCT & 0,000 & GCG & 1,000 & GCG & 1,000 \\
\hline & GGA & 1,000 & GGA & 0,000 & $\mathrm{GCT}$ & 0,006 & GCT & 0,002 \\
\hline & GGC & 0,008 & GGC & 0,148 & GGA & 0,001 & GGA & 0,000 \\
\hline & GGG & 0,000 & GGG & 1,000 & GGG & 0,073 & GGC & 1,000 \\
\hline & GGT & 1,000 & GGT & 0,000 & GGT & 0,036 & GGG & 0,160 \\
\hline & GTA & 0,007 & GTA & 0,000 & GTA & 0,000 & GGT & 0,014 \\
\hline & GTC & 0,003 & GTC & 0,289 & GTC & 1,000 & GTA & 0,000 \\
\hline & GTG & 1,000 & GTG & 0,000 & GTG & 0,054 & GTG & 0,021 \\
\hline & GTT & 1,000 & GTT & 0,000 & GTT & 0,007 & GTT & 0,002 \\
\hline \multirow[t]{15}{*}{ GAG } & GAA & 0,002 GCG & GAA & 0,000 GGG & GAA & $0,000 \mathrm{GTG}$ & GAA & 0,000 \\
\hline & GAC & 0,959 & GAC & 0,001 & GAC & 0,000 & GAC & 1,000 \\
\hline & GAT & 0,000 & GAG & 0,000 & GAG & 0,000 & GAG & 0,677 \\
\hline & GCA & 0,279 & GAT & 0,000 & GAT & 0,000 & GAT & 0,000 \\
\hline & GCC & 0,000 & GCA & 0,065 & GCA & 0,000 & GCA & 1,000 \\
\hline & GCG & 0,000 & GCC & 0,428 & GCC & 1,000 & GCC & 0,000 \\
\hline & GCT & 0,975 & GCT & 0,001 & GCG & 0,259 & GCG & 0,010 \\
\hline & GGA & 1,000 & GGA & 0,000 & $\mathrm{GCT}$ & 0,000 & GCT & 1,000 \\
\hline & GGC & 0,000 & GGC & 1,000 & GGA & 0,000 & GGA & 0,998 \\
\hline & GGG & 0,000 & GGG & 0,259 & GGC & 0,073 & GGC & 0,054 \\
\hline & GGT & 0,769 & GGT & 0,006 & GGT & 0,000 & GGG & 0,000 \\
\hline & GTA & 0,510 & GTA & 0,000 & GTA & 0,000 & GGT & 1,000 \\
\hline & GTC & 0,000 & GTC & 1,000 & GTC & 0,160 & GTA & 0,001 \\
\hline & GTG & 0,677 & GTG & 0,010 & GTG & 0,000 & GTC & 0,021 \\
\hline & GTT & 0,965 & GT & 0,001 & GTT & 0,000 & GTT & 1,000 \\
\hline \multirow[t]{15}{*}{ GAT } & GAA & $0,012 \mathrm{GCT}$ & GAA & 0,000 GGT & GAA & $0,000 \mathrm{GTT}$ & GAA & 0,000 \\
\hline & GAC & 0,000 & GAC & 1,000 & GAC & 1,000 & GAC & 1,000 \\
\hline & GAG & 0,000 & GAG & 0,975 & GAG & 0,769 & GAG & 0,965 \\
\hline & GCA & 0,000 & GAT & 0,000 & GAT & 0,000 & GAT & 0,000 \\
\hline & GCC & 0,000 & GCA & 0,997 & GCA & 1,000 & GCA & 0,998 \\
\hline & GCG & 0,000 & GCC & 0,000 & GCC & 0,000 & GCC & 0,000 \\
\hline & GCT & 0,000 & GCG & 0,001 & GCG & 0,006 & GCG & 0,001 \\
\hline & GGA & 0,000 & GGA & 1,000 & GCT & 1,000 & GCT & 1,000 \\
\hline & GGC & 0,000 & GGC & 0,006 & GGA & 0,999 & GGA & 1,000 \\
\hline & GGG & 0,000 & GGG & 0,000 & GGC & 0,036 & GGC & 0,007 \\
\hline & GGT & 0,000 & GGT & 1,000 & GGG & 0,000 & GGG & 0,000 \\
\hline & GTA & 0,000 & GTA & 0,010 & GTA & 0,001 & GGT & 1,000 \\
\hline & GTC & 0,000 & GTC & 0,002 & GTC & 0,014 & GTA & 0,008 \\
\hline & GTG & 0,000 & GTG & 1,000 & GTG & 1,000 & GTC & 0,002 \\
\hline & GT & 0,000 & GT & 1,000 & GT & 1,000 & GTG & 1,000 \\
\hline
\end{tabular}

\begin{tabular}{|c|c|c|c|c|c|c|c|c|}
\hline \multirow[t]{15}{*}{ GGAA } & GGAC & $0,023 \mathrm{GGCA}$ & GGAA & 0,007 GGGA & GGAA & 0,000 GGTA & GGAA & 0,164 \\
\hline & GGAG & 0,047 & GGAC & 0,968 & GGAC & 0,005 & GGAC & 0,093 \\
\hline & GGAT & 0,069 & GGAG & 0,999 & GGAG & 0,178 & GGAG & 0,787 \\
\hline & GGCA & 0,007 & GGAT & 0,539 & GGAT & 0,000 & GGAT & 0,678 \\
\hline & GGCC & 0,000 & GGCC & 0,109 & GGCA & 0,729 & GGCA & 0,168 \\
\hline & GGCG & 0,001 & GGCG & 0,998 & GGCC & 0,674 & GGCC & 0,000 \\
\hline & GGCT & 0,121 & GGCT & 0,806 & GGCG & 0,996 & GGCG & 0,006 \\
\hline & GGGA & 0,000 & GGGA & 0,729 & GGCT & 0,017 & GGCT & 0,998 \\
\hline & GGGC & 0,000 & GGGC & 0,040 & GGGC & 0,134 & GGGA & 0,000 \\
\hline & GGGG & 0,000 & GGGG & 0,009 & GGGG & 0,012 & GGGC & 0,000 \\
\hline & GGGT & 0,001 & GGGT & 0,283 & GGGT & 0,997 & GGGG & 0,000 \\
\hline & GGTA & 0,164 & GGTA & 0,168 & GGTA & 0,000 & GGGT & 0,000 \\
\hline & GGTC & 0,003 & GGTC & 1,000 & GGTC & 0,508 & GGTC & 0,000 \\
\hline & GGTG & 0,004 & GGTG & 1,000 & GGTG & 0,396 & GGTG & 0,008 \\
\hline & GGT & 1,000 & GGT & 0,476 & GGTT & 0,112 & GGTT & 0,991 \\
\hline \multirow[t]{15}{*}{ GGAC } & GGAA & $0,023 \mathrm{GGCC}$ & GGAA & $0,000 \mathrm{GGGC}$ & GGAA & 0,000 GGTC & GGAA & 0,003 \\
\hline & GGAG & 1,000 & GGAC & 0,000 & GGAC & 0,000 & GGAC & 0,025 \\
\hline & GGAT & 0,928 & GGAG & 0,021 & GGAG & 0,010 & GGAG & 0,673 \\
\hline & GGCA & 0,968 & GGAT & 0,000 & GGAT & 0,000 & GGAT & 0,000 \\
\hline & GGCC & 0,000 & GGCA & 0,109 & GGCA & 0,040 & GGCA & 1,000 \\
\hline & GGCG & 0,182 & GGCG & 0,226 & GGCC & 0,638 & GGCC & 0,000 \\
\hline & GGCT & 0,999 & GGCT & 0,002 & GGCG & 0,056 & GGCG & 1,000 \\
\hline & GGGA & 0,005 & GGGA & 0,674 & GGCT & 0,001 & GGCT & 0,127 \\
\hline & GGGC & 0,000 & GGGC & 0,638 & GGGA & 0,134 & GGGA & 0,508 \\
\hline & GGGG & 0,000 & GGGG & 0,020 & GGGG & 0,127 & GGGC & 0,000 \\
\hline & GGGT & 0,000 & GGGT & 0,644 & GGGT & 0,000 & GGGG & $0,00 \mathrm{C}$ \\
\hline & GGTA & 0,093 & GGTA & 0,000 & GGTA & 0,000 & GGGT & 0,000 \\
\hline & GGTC & 0,029 & GGTC & 0,000 & GGTC & 0,000 & GGTA & 0,000 \\
\hline & GGTG & 0,621 & GGTG & 0,005 & GGTG & 0,002 & GGTG & 0,998 \\
\hline & GGTT & 0,753 & GGTT & 0,047 & GGTT & 0,031 & GGTT & 0,258 \\
\hline \multirow[t]{15}{*}{ GGAG } & GGAA & 0,047 GGCG & GGAA & 0,001 GGGG & GGAA & 0,000 GGTG & GGAA & 0,004 \\
\hline & GGAC & 1,000 & GGAC & 0,182 & GGAC & 0,000 & GGAC & 0,62 \\
\hline & GGAT & 0,998 & GGAG & 0,665 & GGAG & 0,002 & GGAG & 0,977 \\
\hline & GGCA & 0,999 & GGAT & 0,024 & GGAT & 0,000 & GGAT & 0,068 \\
\hline & GGCC & 0,021 & GGCA & 0,998 & GGCA & 0,009 & GGCA & 1,000 \\
\hline & GGCG & 0,665 & GGCC & 0,226 & GGCC & 0,020 & GGCC & 0,005 \\
\hline & GGCT & 1,000 & GGCT & 0,144 & GGCG & 0,008 & GGCG & 0,993 \\
\hline & GGGA & 0,178 & GGGA & 0,996 & GGCT & 0,000 & GGCT & 0,459 \\
\hline & GGGC & 0,010 & GGGC & 0,056 & GGGA & 0,012 & GGGA & 0,396 \\
\hline & GGGG & 0,002 & GGGG & 0,008 & GGGC & 0,127 & GGGC & 0,002 \\
\hline & GGGT & 0,057 & GGGT & 0,629 & GGGT & 0,000 & GGGG & 0,000 \\
\hline & GGTA & 0,787 & GGTA & 0,006 & GGTA & 0,000 & GGGT & 0,03 \\
\hline & GGTC & 0,673 & GGTC & 1,000 & GGTC & 0,000 & GGTA & 0,008 \\
\hline & GGTG & 0,977 & GGTG & 0,993 & GGTG & 0,000 & GGTC & 0,998 \\
\hline & GGTT & 0,814 & GGTT & 0,219 & GGTT & 0,017 & GGTT & 0,384 \\
\hline \multirow[t]{15}{*}{ GGAT } & GGAA & 0,069 GGCT & GGAA & 0,121 GGGT & GGAA & $0,001 \mathrm{GGTT}$ & GGAA & 1,000 \\
\hline & GGAC & 0,928 & GGAC & 0,999 & GGAC & 0,000 & GGAC & 0,753 \\
\hline & GGAG & 0,998 & GGAG & 1,000 & GGAG & 0,057 & GGAG & 0,814 \\
\hline & GGCA & 0,539 & GGAT & 1,000 & GGAT & 0,000 & GGAT & 0,929 \\
\hline & GGCC & 0,000 & GGCA & 0,806 & GGCA & 0,283 & GGCA & 0,476 \\
\hline & GGCG & 0,024 & GGCC & 0,002 & GGCC & 0,644 & GGCC & 0,047 \\
\hline & GGCT & 1,000 & GGCG & 0,144 & GGCG & 0,629 & GGCG & 0,219 \\
\hline & GGGA & 0,000 & GGGA & 0,017 & GGCT & 0,006 & GGCT & 0,957 \\
\hline & GGGC & 0,000 & GGGC & 0,001 & GGGA & 0,997 & GGGA & 0,112 \\
\hline & GGGG & 0,000 & GGGG & 0,000 & GGGC & 0,000 & GGGC & 0,031 \\
\hline & GGGT & 0,000 & GGGT & 0,006 & GGGG & 0,000 & GGGG & 0,017 \\
\hline & GGTA & 0,678 & GGTA & 0,998 & GGTA & 0,000 & GGGT & 0,075 \\
\hline & GGTC & 0,000 & GGTC & 0,127 & GGTC & 0,000 & GGTA & 0,991 \\
\hline & GGTG & 0,068 & GGTG & 0,459 & GGTG & 0,031 & GGTC & 0,258 \\
\hline & GGTT & 0,929 & GGT & 0,957 & GGT & 0,075 & GGTG & 0,384 \\
\hline
\end{tabular}


U6T7 promóter eredményeihez kapcsolódó p értékek

$(0,000$ jelentése $<0,001)$

48. ábra

\begin{tabular}{|ccc|}
\hline$A$ & $C$ & 0,000 \\
& $G$ & 0,001 \\
T & 0,999 \\
$C$ & $A$ & 0,000 \\
G & 0,000 \\
T & 0,000 \\
G & A & 0,001 \\
C & 0,000 \\
T & 0,000 \\
$T$ & $A$ & 0,999 \\
C & 0,000 \\
G & 0,000 \\
\hline
\end{tabular}

49. ábra

\begin{tabular}{|c|c|c|c|c|c|c|c|c|}
\hline \multirow[t]{15}{*}{ AA } & $A A C$ & $0,998 \mathrm{CA}$ & AA & $1,000 \mathrm{GA}$ & AA & $0,011 \mathrm{TA}$ & AA & 0,000 \\
\hline & AG & 0,000 & $A C$ & 1,000 & $A C$ & 0,016 & $A C$ & 0,000 \\
\hline & AT & 0,246 & $A G$ & 0,000 & $A G$ & 0,629 & $A G$ & \\
\hline & CA & 1,000 & AT & 0,301 & AT & 0,164 & AT & $0,0 C$ \\
\hline & $\mathrm{CC}$ & 0,220 & $\mathrm{CC}$ & 0,196 & $\mathrm{CA}$ & 0,012 & $\mathrm{CA}$ & $0,0 C$ \\
\hline & CG & 0,643 & CG & 0,541 & $\mathrm{CC}$ & 0,000 & $\mathrm{CC}$ & 0,0 \\
\hline & CT & 0,014 & CT & 0,011 & CG & 0,003 & CG & 0,0 \\
\hline & GA & 0,011 & GA & 0,012 & CT & 0,000 & CT & 0,0 \\
\hline & GC & 0,552 & $\mathrm{GC}$ & 0,801 & $\mathrm{GC}$ & 0,022 & GA & \\
\hline & GG & 0,000 & GG & 0,000 & GG & 0,054 & $\mathrm{GC}$ & \\
\hline & GT & 0,000 & GT & 0,000 & GT & 0,974 & GG & \\
\hline & TA & 0,000 & TA & 0,000 & TA & 0,962 & GT & \\
\hline & TC & 0,172 & TC & 0,234 & TC & 0,082 & TC & \\
\hline & TG & 0,000 & TG & 0,000 & TG & 0,141 & TG & 0,0 \\
\hline & $\pi$ & 0,996 & $\pi$ & 0,989 & $\pi$ & 0,004 & $\pi$ & 0,0 \\
\hline \multirow[t]{15}{*}{$A C$} & $\mathrm{AA}$ & $0,998 \mathrm{CC}$ & AA & $0,220 \mathrm{GC}$ & AA & $0,552 \mathrm{TC}$ & AA & \\
\hline & AG & 0,000 & $A C$ & 0,141 & $A C$ & 1,000 & $A C$ & \\
\hline & AT & 0,543 & $A G$ & 0,000 & $A G$ & 0,000 & $A G$ & \\
\hline & $\mathrm{CA}$ & 1,000 & AT & 0,020 & AT & 0,625 & AT & \\
\hline & $\mathrm{CC}$ & 0,141 & CA & 0,196 & CA & 0,801 & CA & \\
\hline & CG & 0,331 & CG & 0,746 & $\mathrm{CC}$ & 0,102 & $\mathrm{CC}$ & \\
\hline & CT & 0,006 & CT & 1,000 & CG & 0,112 & CG & \\
\hline & GA & 0,016 & GA & 0,000 & CT & 0,004 & CT & \\
\hline & GC & 1,000 & GC & 0,102 & GA & 0,022 & GA & \\
\hline & GG & 0,000 & GG & 0,000 & GG & 0,000 & $\mathrm{GC}$ & \\
\hline & GT & 0,000 & GT & 0,000 & GT & 0,000 & GG & \\
\hline & TA & 0,000 & TA & 0,000 & TA & 0,000 & GT & \\
\hline & TC & 0,562 & TC & 0,028 & TC & 0,631 & TA & \\
\hline & TG & 0,006 & TG & 0,015 & TG & 0,000 & TG & \\
\hline & $\pi$ & 0,933 & $\pi$ & 0,701 & $\pi$ & 0,746 & $\pi$ & \\
\hline \multirow[t]{15}{*}{ AG } & $G \mathrm{AA}$ & $0,000 \mathrm{CG}$ & AA & $0,643 \mathrm{GG}$ & AA & $0,000 \mathrm{TG}$ & AA & \\
\hline & $A C$ & 0,000 & $A C$ & 0,331 & $A C$ & 0,000 & $A C$ & \\
\hline & AT & 0,000 & $A G$ & 0,000 & $A G$ & 0,314 & $A G$ & \\
\hline & CA & 0,000 & AT & 0,038 & AT & 0,000 & AT & \\
\hline & $\mathrm{CC}$ & 0,000 & CA & 0,541 & CA & 0,000 & CA & \\
\hline & CG & 0,000 & $\mathrm{CC}$ & 0,746 & $\mathrm{CC}$ & 0,000 & $\mathrm{CC}$ & \\
\hline & CT & 0,000 & CT & 0,320 & CG & 0,000 & CG & \\
\hline & GA & 0,629 & GA & 0,003 & CT & 0,000 & CT & \\
\hline & $\mathrm{GC}$ & 0,000 & $\mathrm{GC}$ & 0,112 & GA & 0,054 & GA & \\
\hline & GG & 0,314 & GG & 0,000 & $\mathrm{GC}$ & 0,000 & $\mathrm{GC}$ & \\
\hline & GT & 0,999 & GT & 0,000 & GT & 0,180 & GG & \\
\hline & TA & 0,988 & TA & 0,000 & TA & 0,094 & GT & \\
\hline & TC & 0,000 & TC & 0,020 & TC & 0,000 & TA & \\
\hline & TG & 0,000 & TG & 0,001 & TG & 0,000 & TC & \\
\hline & $\pi$ & 0,000 & $\pi$ & 1,000 & $\pi$ & 0,000 & $\pi$ & \\
\hline \multirow[t]{15}{*}{ AT } & AA & $0,246 \mathrm{CT}$ & AA & 0,014 GT & AA & $0,000 \pi$ & AA & \\
\hline & $A C$ & 0,543 & $A C$ & 0,006 & $A C$ & 0,000 & $A C$ & \\
\hline & AG & 0,000 & $A G$ & 0,000 & $A G$ & 0,999 & $A G$ & \\
\hline & CA & 0,301 & AT & 0,001 & AT & 0,001 & AT & \\
\hline & $\mathrm{CC}$ & 0,020 & CA & 0,011 & CA & 0,000 & CA & \\
\hline & CG & 0,038 & $\mathrm{CC}$ & 1,000 & $\mathrm{CC}$ & 0,000 & $\mathrm{CC}$ & \\
\hline & CT & 0,001 & CG & 0,320 & CG & 0,000 & CG & \\
\hline & GA & 0,164 & GA & 0,000 & CT & 0,000 & CT & \\
\hline & C & 0,625 & $\mathrm{GC}$ & 0,004 & GA & 0,974 & GA & \\
\hline & GG & 0,000 & GG & 0,000 & $\mathrm{GC}$ & 0,000 & $\mathrm{GC}$ & \\
\hline & GT & 0,001 & GT & 0,000 & GG & 0,180 & GG & \\
\hline & TA & 0,000 & TA & 0,000 & TA & 1,000 & GT & \\
\hline & TC & 1,000 & TC & 0,000 & TC & 0,000 & TA & \\
\hline & TG & 1,000 & TG & 0,000 & TG & 0,001 & TC & \\
\hline & $\pi$ & 0,209 & $\pi$ & 0,382 & $\pi$ & 0,000 & TG & \\
\hline
\end{tabular}


J23119 promóter eredményeihez kapcsolódó p értékek

$(0,000$ jelentése $<0,001)$

53. ábra

\begin{tabular}{|ccc}
\hline$A$ & $C$ & 0,000 \\
& $G$ & 0,612 \\
& $T$ & 0,000 \\
$C$ & $A$ & 0,000 \\
& G & 0,000 \\
T & 0,000 \\
G & A & 0,612 \\
C & 0,000 \\
T & 0,000 \\
$T$ & $A$ & 0,000 \\
C & 0,000 \\
G & 0,000 \\
\hline
\end{tabular}

54. ábra

\begin{tabular}{|c|c|c|c|c|c|c|c|c|}
\hline \multirow[t]{15}{*}{ AA } & $A C$ & $0,000 \mathrm{CA}$ & AA & $0,000 \mathrm{GA}$ & AA & 1,000 TA & AA & 1,000 \\
\hline & AG & 0,000 & $A C$ & 0,330 & $A C$ & 0,000 & $A C$ & 0,000 \\
\hline & AT & 0,000 & $A G$ & 0,000 & $A G$ & 0,000 & $A G$ & 0,000 \\
\hline & CA & 0,000 & AT & 0,000 & AT & 0,000 & AT & 0,000 \\
\hline & CC & 0,000 & $\mathrm{CC}$ & 0,000 & $\mathrm{CA}$ & 0,000 & CA & 0,000 \\
\hline & CG & 0,000 & CG & 0,983 & $\mathrm{CC}$ & 0,000 & CC & 0,000 \\
\hline & CT & 0,000 & CT & 0,003 & CG & 0,000 & CG & 0,000 \\
\hline & GA & 1,000 & GA & 0,000 & CT & 0,000 & CT & 0,000 \\
\hline & GC & 0,000 & GC & 0,033 & $\mathrm{GC}$ & 0,000 & GA & 0,081 \\
\hline & GG & 0,396 & GG & 0,000 & GG & 0,081 & GC & 0,000 \\
\hline & GT & 0,000 & GT & 0,001 & GT & 0,000 & GG & 0,010 \\
\hline & TA & 1,000 & TA & 0,000 & TA & 0,081 & GT & 0,000 \\
\hline & TC & 0,000 & TC & 0,467 & TC & 0,000 & TC & 0,000 \\
\hline & TG & 0,963 & TG & 0,000 & TG & 0,432 & TG & 0,905 \\
\hline & $\pi$ & 0,000 & $\pi$ & 0,482 & $\pi$ & 0,000 & $\pi$ & 0,000 \\
\hline \multirow[t]{15}{*}{$A C$} & AA & $0,000 \mathrm{CC}$ & AA & $0,000 \mathrm{GC}$ & AA & $0,000 \mathrm{TC}$ & AA & 0,000 \\
\hline & AG & 0,000 & $\mathrm{AC}$ & 0,000 & $A C$ & 0,738 & $A C$ & 0,001 \\
\hline & AT & 0,000 & AG & 0,000 & AG & 0,000 & $A G$ & 0,000 \\
\hline & CA & 0,330 & AT & 0,000 & AT & 0,000 & AT & 0,000 \\
\hline & $\mathrm{CC}$ & 0,000 & CA & 0,000 & CA & 0,033 & $\mathrm{CA}$ & 0,467 \\
\hline & CG & 1,000 & CG & 0,000 & $\mathrm{CC}$ & 0,000 & $\mathrm{CC}$ & 0,000 \\
\hline & CT & 0,001 & CT & 1,000 & CG & 0,599 & CG & 0,185 \\
\hline & GA & 0,000 & GA & 0,000 & CT & 0,000 & CT & 0,010 \\
\hline & GC & 0,738 & GC & 0,000 & GA & 0,000 & GA & 0,000 \\
\hline & GG & 0,000 & GG & 0,000 & GG & 0,000 & GC & 0,001 \\
\hline & GT & 0,218 & GT & 0,000 & GT & 1,000 & GG & 0,000 \\
\hline & TA & 0,000 & TA & 0,000 & TA & 0,000 & GT & 0,000 \\
\hline & TC & 0,001 & TC & 0,000 & TC & 0,001 & TA & 0,000 \\
\hline & TG & 0,000 & TG & 0,000 & TG & 0,000 & TG & 0,000 \\
\hline & $\pi$ & 0,996 & $\pi$ & 0,000 & $\pi$ & 1,000 & $\pi$ & 0,095 \\
\hline \multirow[t]{15}{*}{ AG } & $A A$ & $0,000 \mathrm{CG}$ & AA & $0,000 \mathrm{GG}$ & AA & 0,396 TG & AA & 0,963 \\
\hline & $A C$ & 0,000 & $A C$ & 1,000 & $A C$ & 0,000 & $A C$ & 0,000 \\
\hline & AT & 0,000 & AG & 0,000 & AG & 0,000 & $A G$ & 0,000 \\
\hline & CA & 0,000 & AT & 0,000 & AT & 0,000 & AT & 0,000 \\
\hline & $\mathrm{CC}$ & 0,000 & CA & 0,983 & CA & 0,000 & $\mathrm{CA}$ & 0,000 \\
\hline & CG & 0,000 & $\mathrm{CC}$ & 0,000 & $\mathrm{CC}$ & 0,000 & CC & 0,000 \\
\hline & CT & 0,000 & CT & 0,001 & CG & 0,000 & CG & 0,000 \\
\hline & GA & 0,000 & GA & 0,000 & CT & 0,000 & CT & \\
\hline & GC & 0,000 & GC & 0,599 & GA & 0,081 & GA & \\
\hline & GG & 0,000 & GG & 0,000 & GC & 0,000 & GC & 0,000 \\
\hline & GT & 0,000 & GT & 0,299 & GT & 0,000 & GG & 0,023 \\
\hline & TA & 0,000 & TA & 0,000 & TA & 0,010 & GT & 0,000 \\
\hline & TC & 0,000 & TC & 0,185 & TC & 0,000 & TA & \\
\hline & TG & 0,000 & TG & 0,000 & TG & 0,023 & TC & \\
\hline & $\pi$ & 0,000 & $\pi$ & 0,966 & $\pi$ & 0,000 & $\pi$ & 0,000 \\
\hline \multirow[t]{15}{*}{ AT } & AA & $0,000 \mathrm{CT}$ & AA & $0,000 \mathrm{GT}$ & AA & $0,000 \pi$ & AA & 0,000 \\
\hline & $A C$ & 0,000 & $A C$ & 0,001 & $A C$ & 0,218 & $A C$ & 0,996 \\
\hline & AG & 0,000 & AG & 0,000 & AG & 0,000 & AG & \\
\hline & CA & 0,000 & AT & 0,003 & AT & 0,000 & AT & \\
\hline & $\mathrm{CC}$ & 0,000 & $\mathrm{CA}$ & 0,003 & CA & 0,001 & CA & 0,482 \\
\hline & CG & 0,000 & $\mathrm{CC}$ & 1,000 & $\mathrm{CC}$ & 0,000 & $\mathrm{CC}$ & 0,000 \\
\hline & CT & 0,003 & CG & 0,001 & CG & 0,299 & CG & 0,966 \\
\hline & GA & 0,000 & GA & 0,000 & CT & 0,000 & СT & 0,000 \\
\hline & C & 0,000 & GC & 0,000 & GA & 0,000 & GA & 0,000 \\
\hline & GG & 0,000 & GG & 0,000 & GC & 1,000 & GC & 1,000 \\
\hline & GT & 0,000 & GT & 0,000 & GG & 0,000 & GG & 0,000 \\
\hline & TA & 0,000 & TA & 0,000 & TA & 0,000 & GT & 1,000 \\
\hline & TC & 0,000 & TC & 0,010 & TC & 0,000 & TA & 0,000 \\
\hline & TG & 0,000 & TG & 0,000 & TG & 0,000 & TC & 0,095 \\
\hline & $\pi$ & 0,000 & $\pi$ & 0,000 & $\pi$ & 1,000 & TG & \\
\hline
\end{tabular}

